Universidad Nacional de La Plata (UNLP)

Facultad de Periodismo y Comunicación Social

"Cuando termine de contar, ¿me voy a seguir acordando de lo que pasó?" Análisis de relatos sobre la experiencia del abuso sexual contra niños, niñas y jóvenes en clave comunicacional

\author{
Trabajo de tesis para optar por el título de \\ DOCTOR EN COMUNICACIÓN
}

Autora: M. Rosaura Barrios (IISH/CONICET- UNaM)

Directora: Dra. Ana María Mendes Díz (IIGG/ UBA- CONICET)

Co Director: Dr. Marcelino García (FHyCS/ UNaM)

\title{
La Plata
}

Agosto 2016 
A Natiú y Rafaela,

que de amorosas nada tenían.

Eran pura fuerza y sobrevivencia. 
Agradecimientos:

La lista sería bastante más larga y no me alcanzarían los días para agradecer tanta entrega y confianza. Pero haremos el intento.

A Marita y todo su equipo que con formación pero sobre todo con amor y compromiso encaran día a día el trabajo de sanar heridas.

A los y las militantes, a todos y todas que prestaron sus palabras para que esta tesis pueda realizarse, a los gritos en las calles, en las marchas, en los escraches. Gracias por mostrarme el camino de la búsqueda constante de justicia pero sobre todo de paz.

A mi directora y a mi co director por las lecturas minuciosas, correcciones $y$ por la confianza casi ciega en este proyecto, en mi persona. A ustedes, todo.

A mi familia, que gracias a la vida se compone de muchas amigas, padres y hermano, a ustedes todo lo que soy y lo que hago. Mi eterno amor y cariño.

A mi compañero de siempre. Esto también es tuyo.

A CONICET que como parte del Estado Argentino financió este proyecto para la formación de profesionales en grandes centros urbanos. Sin el programa de becas AVG no podría haber tocado el cielo como me siento en estos momentos.

Y como diría una querida amiga y colega: Gracias a la Universidad Pública, Gratuita y Científica por la oportunidad. En tiempos difíciles la educación pública se defiende en las calles sí pero siempre con el compromiso de formarnos constantemente, con el corazón y la mente puestos (siempre) al servicio de este gran pueblo. 
Índice

Introducción

Capítulo 1.

El Campo. Las Disciplinas. Los Debates

I. Primera Escena/ Situación Comunicativa 28

II. Segunda escena/situación comunicativa 44

Cierre 59

Capítulo 2.

Encuadre Teórico- Metodológico

Primera Parte

I. Cruces teóricos 65

$\begin{array}{ll}\text { II. Categorías Analíticas } & 74\end{array}$

Segunda Parte

I. Lo metodológico. El oficio sigue siendo buscar 92

II. Crónicas para no perderse 100

$\begin{array}{ll}\text { III. Herramientas y categorías } & 106\end{array}$

IV. ¿El fin de la buena fe en Ciencias Sociales? 118

Capítulo 3.

Análisis

I. Primera Situación Comunicativa 130

$\begin{array}{ll}\text { II. Segunda Situación Comunicativa } & 171\end{array}$

III. De la institucionalización de la figura del monstruo: El Perverso 196

IV. El último pasaje de formas: la codificación académica 205

$\begin{array}{ll}\text { (In)conclusiones } & 208\end{array}$

$\begin{array}{lr}\text { Bibliografía } & 214\end{array}$ 


\section{Introducción}

En medio de las diversas intervenciones disciplinares posibles, y las múltiples herramientas de análisis disponibles, problemas de investigación, procedimientos o culturas investigativas esta tesis se inscribe dentro de los estudios en comunicación que tienen que ver con Cultura y Sociedad, pero se ubica en las fronteras con otras disciplinas científicas como la Antropología, la Psicología, la Criminalística y el Derecho. La lectura de materiales analíticos como los conformados para esta tesis nos devuelve la posibilidad y la necesidad de trabajar de manera interdisciplinar, característica propia y madre de los estudios en comunicación, veremos como la confección de un problema y su búsqueda reflexiva pide la intervención de otras miradas y herramientas. Quizás por nuestros orígenes interdisciplinares contamos en nuestra formación con las dinámicas del diálogo, la búsqueda de consensos y discrepancias con otras disciplinas científicas. Los estudios en Comunicación desde sus inicios y hasta la actualidad se centraron principalmente en el estudio de los medios industriales de comunicación, focalizando sus problemas en el análisis de corpus producto de los medios o que se despliegan con el accionar de estos. Pero el cruce de disciplinas como la antropología nos habilita todo un abanico de opciones a la hora de investigar en comunicación, la pregunta ¿tenemos una mirada específica con respecto a ciertos problemas? Sigue causando cierta picazón a más de uno/a. Esta es la pregunta que sobrevuela a todo el trabajo de investigación y busca ser respondida en todo momento, ¿cuál es el aporte de comunicadores y comunicadoras al estudio de experiencias traumáticas en diálogo con organizaciones sociales?

Con experiencia traumática nos referimos al abuso sexual infantil, que si me leería la especialista Eva Giberti me corregiría. Se denomina “incesto", me contestaría, esa es su correcta denominación. ¿Cómo, desde la comunicación podemos analizar los relatos de experiencias traumáticas en determinadas situaciones comunicativas? ¿Qué aporte disciplinar podemos prestar al estudio social de su enunciación? Esta incomodidad estuvo presente durante todo el trabajo, ¿cómo resolvemos disciplinar y analíticamente el problema de la enunciación de estas experiencias?, ¿qué sentido tendría incorporar comunicadoras y comunicadores a los equipos que trabajan con estos 
problemas sociales? Aquí y con este problema estuvimos en campo, confeccionamos mapas para indagar en estas aguas, siempre con las fronteras disciplinares cargando en nuestras espaldas y en diálogo constante, ¿cómo afinar la mirada comunicacional?

No podíamos olvidar que el recorte decía ser disciplinar a pesar de dialogar constantemente. El desafío de esta investigación, que se inscribe en estudios de comunicación, fue darle un fuerte corte etnográfico y la confección de herramientas metodológicas que dieran respuesta a las diversas encrucijadas éticas, políticas y filosóficas que tuvimos desde el principio. Es comunicacional el recorte y su mirada pero tuvimos que recurrir a otras teorías para construir su mapeo, estos son los Estudios de Género y Sexualidad y los Estudios Culturales en Comunicación.

\section{Un Mapeo Analitico}

En la articulación de los Estudios Poscoloniales de Género y los Estudios Culturales en Comunicación es que tensaremos la discusión sobre Experiencia Traumática y Narrativas, ejes articuladores de la tesis. Lo que nos interesa de ambas perspectivas es la desconstrucción que hacen de la noción misma de identidad y su empalme, o ubicación en mapas superpuestos, para dar cuenta de los relatos y de las condiciones de enunciación/ producción de los mismos. Los relatos serán arena de lucha por los sentidos, pero estas luchas no se dan de manera aislada, sino ancladas, ubicadas, trazando fronteras, estableciendo límites (¿porosos?)

Los Estudios de Género y Sexualidad, a partir del problema de la voz del subalterno (Spivak) y el debate en torno al testimonio y a la autoridad narrativa (Oberti), tensarán las preguntas de este trabajo, tejiendo distintas tramas/dramas que constituyen los nudos de nuestras reflexiones: ¿cuáles son los límite/periferia en estos debates? Y por consecuencia, ¿dónde está el centro? En términos de Kristeva (1989) ¿quiénes son los/as otros/as/abyectos en estas tramas? ¿qué tanto pueden hablar en el contexto de estas instituciones/organizaciones con características tan rígidas?

Entre estos debates existen puntos de contacto con los Estudios Culturales en Comunicación, ambos dan cuenta de las dificultades de estudiar a un otro/a, de la violencia académica que significa la "domesticación" de sus prácticas / narrativas / sentires al traducirlas a un lenguaje codificado / articulado científico. Ambas 
perspectivas fundantes en la idea de contextualizar los análisis, y en esta contextualización de las reflexiones, la experiencia como insumo sensible para ser parte de los materiales de análisis, como única "escapatoria" a las trampas del subjetivismo (Haraway); esto es a partir del cruce entre condiciones de existencia y la producción del relato. El objetivo es localizar las continuidades, quiebres, cambios o no, que sugieren los relatos de experiencia traumática en distintas situaciones comunicativas.

El gran desafío de este trabajo resultó ser la reflexión y la construcción de una metodología acorde a las condiciones de producción de estas preguntas de investigación y del campo seleccionado. El problema social que significa el delito de abuso sexual infantil está mediado por protocolos de acción y abordaje desde varias disciplinas, esto condicionó desde el inicio los lineamientos de este trabajo. Lejos de entorpecer los análisis, formaron parte de los mismos materiales de estudio en una segunda etapa de la investigación. A lo largo del trabajo veremos cómo el problema se complejizó y su acceso se hacía aun más complicado. Con este panorama, la metodología fue pensada luego de varias exploraciones en campo sin registros, el desafío fue pensar y reflexionar una modalidad de abordaje y construcción de los datos acorde con la problemática, respetando protocolos y reglamentos internos de cada organización y con la rigurosidad que cualquier trabajo de carácter científico demanda.

La analogía con un mapa no es casual. La experiencia corporal y sensorial de trabajar con el dolor ajeno no solo nos atraviesa sino que, por momentos, nos alejó un tanto de los objetivos principales de este trabajo. Entonces, la construcción de un mapa con los obstáculos y esos obstáculos convertidos en problemas de reflexión contribuyeron a construir una metodología flexible a los fines de este problema. Y a ubicarnos analíticamente. Confiamos en que la mirada comunicacional es un insumo fundamental para la comprensión del fenómeno de contar la experiencia traumática en situaciones donde interviene la justicia, por un lado; y en calidad de reparación interna, por el otro. 


\section{La Comunicación en diálogo (constante)}

¿Cómo dialogamos con otras disciplinas? ¿Cómo construimos un problema polifónico? ¿Qué aporta -en definitiva- una comunicadora a estas tramas? ¿Cuál es la particularidad de su mirada para su inclusión a equipos de trabajo que aborden la experiencia traumática?

Nuestro foco de atención no fueron los relatos en sí, ni siquiera fue el acceso a la situación que provocó esa experiencia dolorosa, nuestro foco de atención fue las condiciones que permitieron o facilitaron que esa experiencia traumática pueda ser enunciada. Si la cultura organizacional ya es una maraña, un tejido denso con reglamentos internos, protocolos nacionales e internacionales ¿cómo es posible la enunciación del relato que tiene que ver con un delito en particular? Y por si fuera poco, la edad de las personas que la enuncian obliga a una reglamentación bien específica debido a la máxima protección que demandan. ¿Cómo se cuenta el dolor?, ¿cómo se utiliza institucionalmente un relato para convertirlo en prueba irrefutable de daño?

Ante estas preguntas irremediablemente dialogamos con otras disciplinas que tienen participación activa en el estudio del problema del incesto. ¿Cómo dialogamos con la sicología, el trabajo social, la medicina forense? Y en este diálogo, ¿cómo construimos una mirada propia, plural, rigurosa y metodológica? La "salida" a estos laberintos la encontramos en lo metodológico, fue esa la veta que nos permitió dialogar sin perder especificidad y consistencia.

Así, y con todo esto, presentamos esta tesis en tres capítulos: el primero es en su mayoría descriptivo, presenta todo lo que rodea al problema del abuso sexual a niños, niñas y jóvenes: sus implicancias legales, asistencia psicológica, intervención de la justicia y accionar. En una segunda parte de este mismo capítulo, la descripción de las dos situaciones comunicativas con las que trabajamos y cómo se articulan entre sí en la "lucha" y militancia (en términos de los mismos sujetos que intervienen en esta investigación) a favor de la palabra de los niños y niñas.

El segundo capítulo es el detalle metodológico y teórico de la tesis, este es quizás el capítulo más "conflictivo" del material, fue pensado, intervenido, borrado y vuelto a pensar varias y muchas veces en el proceso de investigación. Bien me dijo una investigadora renombrada de la UBA en ocasión de una reunión informal, café de por medio: "meterse con delitos a menores es como meterse en camisa de once varas." Y es 
que los cuidados y atenciones que hay que tener dificultan no solo el acceso sino la escritura y la reflexión. La vigilancia se agudiza y se entrena para abordar determinadas edades en determinados contextos.

El último y tercer capítulo es el análisis de todo el material, está organizada por ejes y en el orden en que fuimos abordando el problema en campo. El fuerte de este capítulo es la construcción de una investigación que dialogó en todo momento y respetó los aportes de cada disciplina interviniente, entonces el desafío fue doble: teníamos que poder darle carácter y fuerza comunicacional al trabajo. En términos de investigación y como bien dijo una querida profesora de mi Universidad, "en comunicación preferimos hablar de la habilitación de espacios de charla con el otro que permitan terminar de cerrar o terminar de vivir la experiencia... se traduce en escucha para nosotras pero habilita la palabra al otro", en respuesta a la pregunta de un metodólogo sobre nuestro acceso a la experiencia traumática del otro. Este trabajo es el resultado de ese habilitar espacios de charla para la investigación social, es el resultado del diálogo disciplinar para acceder a la experiencia traumática del incesto. 
"Son casi las 7 y yo debería proponer el primer brindis, es mi deber como hijo mayor, ¿verdad Hehnut? Pero primero un discurso. Tengo escritos dos...padre. Uno es verde, el otro es amarillo... tú elige. Uno verde, otro amarillo.

El verde es una elección interesante. Es un discurso casero, "Cuando papá tomaba su baño". (Risas en la mesa) Yo era muy joven cuando nos mudamos aqui, para nosotros los tiempos cambiaron completamente, teníamos todo el espacio que queríamos y todos los problemas que podíamos causar en ese espacio. En esos días este cuarto era un restaurante. Muchas veces mi hermana Linda, quien ya está muerta, y yo jugábamos aquí. Ella ponía cosas en la comida de la gente sin que ellos se dieran cuenta. Nosotros nos escondíamos entonces ella comenzaba a reir, tenía la risa mas contagiosa que puedan ustedes imaginarse, todo el tiempo nos estábamos carcajeando y claro, nos pescaban. Pero nunca nos pasó nada.

Era mucho más peligroso cuando papá tomaba su baño, no sé si lo recuerdan pero el siempre tomaba baños. Nos llevaba a Linda y a mí dentro del estudio pues ahí había algo que él tenía que hacer antes. Entonces cerraba la puerta y bajaba las persianas. Se quitaba el pantalón y la camisa y nos hacia hacer lo mismo. Luego nos colocaba en el sofá verde, que ya no está, y nos violaba. Nos abusaba sexualmente. Tenía sexo con sus pequeños. Hace un par de meses cuando murió mi hermana noté que Helge era un hombre muy limpio con todos esos baños, pensé que debía compartirlo con el resto de la familia. Baños en verano, baños en otoño, baños en primavera, en invierno por las mañanas y por las noches. Helge es un hombre muy limpio, quería que lo supieran ahora que celebramos su cumpleaños número 60 ;Vaya tipo! Imagínenlo, viviendo una larga vida, viendo a sus hijos crecer y nietos.

Pero ustedes no vinieron a escucharme a mí, vinimos a celebrar los 60 años de Helge, así que hagámoslo. Gracias por todos esos buenos años"1.

\footnotetext{
${ }^{1}$ De la película danesa "Die Feste" (La Celebración) de 1998. Discurso de Chistian en el cumpleaños número 60 de su padre ante una mesa llena de invitados/as.
} 


\section{Capítulo 1}

\section{El Campo. Las Disciplinas. Los Debates}

Descripciones de un campo (fuertemente) intervenido

\section{Introducción}

Las siguientes líneas buscan trazar los principales debates y definiciones de las disciplinas que intervienen en el pasaje de formas de la experiencia traumática -como vivencia- del abuso sexual o violación, a la enunciación de narrativas en determinadas escenas y situaciones comunicativas y su posterior codificación en clave de delito sexual para la intervención de la justicia. Atravesar las distintas disciplinas que intervienen con sus protocolos, formas de aplicación y estudio en sí de la problemática son el mapeo de la construcción del problema. El/la lector/a encontrará voces de profesionales con amplia trayectoria y estudio en: Psicología, Trabajo Social, Criminalística y Derecho. Este capítulo -descriptivo en su mayoría- mediante distintas voces buscó cristalizar la polifonía de este problema desde cualquiera de sus miradas. Como veremos, las huellas discursivas que adquiere el relato tienen muchas aristas, voces e interpretaciones que provienen de distintos lugares. Estas líneas son las primeras coordenadas para ubicar esos lugares.

El objetivo es trazar el recorrido que hace y la codificación de la experiencia narrativa del abuso sexual en dos situaciones comunicativas concretas. Por un lado, una ONG en provincia de Buenos Aires, en contexto de evaluación psicodiagnóstica en cámara gesell a través del informe forense de la terapeuta. Y, por el otro, un grupo solidario de pares que funciona en ciudad de Buenos Aires, como colectivo de adultos que se autoperciben como sobrevivientes de abuso sexual infantil. 
El trabajo de campo va desde junio del 2012, hasta diciembre del 2014 en AMBA (Área Metropolitana de Buenos Aires) y se corresponde con la primera parte de la beca doctoral (ex Tipo 1) AVG otorgada por CONICET.

\section{Definiciones}

\section{-Advertencias-}

El/la lector/a de estas líneas va a encontrar un fuerte cruce discursivo/disciplinar (y reflexivo esperemos) entre el campo de la psicología y el derecho penal. Esto da cuenta del fuerte (e íntimo quizás) diálogo que desde la comunicación tuvimos que hacer para construir el objeto en cuestión. Con el objetivo de esclarecer oscuros es que tiene aportes, voces y huellas de varias disciplinas, convencidas de que el trabajo interdisciplinar es necesario para problemáticas como las aquí presentadas.

Todas las autoras y autores aquí citados son referentes en sus respectivas disciplinas no sólo en la lucha y asistencia sino en el estudio de la problemática del abuso sexual contra niños, niñas y adolescentes.

Para este trabajo consideramos como abuso sexual hacia niños, niñas y adolescentes a:

“<... involucrar a un niño/a en actividades sexuales que no llega a comprender totalmente, a las cuales no está en condiciones de dar consentimiento informado, o para las cuáles está evolutivamente inmaduro y tampoco puede dar consentimiento, o en actividades sexuales que transgreden las leyes o las restricciones sociales.

El abuso sexual infantil se manifiesta en actividades entre un niño/a y un/a adulto/a, o entre un niñola y otra persona que, por su edad o por su desarrollo, se encuentra en posición de responsabilidad, confianza o poder. Estas actividades cuyo fin es gratificar o satisfacer las necesidades de la otra persona-abarcan pero no se limitan a la inducción a que un/a niño/a se involucre en cualquier tipo de actividad sexual ilegal, la explotación de niños/as a través de la prostitución o 
de otras formas de prácticas sexuales ilegales y la explotación de niños/as en la producción de materiales y exhibiciones pornográficas”

(Organización Mundial de la Salud -OMS- Octubre de 2001)

“Los artículos 34 y 35 de la Convención sobre los Derechos del Niño dicen que los gobiernos deben proteger a los niños y niñas de todas las formas de explotación y abusos sexuales y tomar todas las medidas posibles para asegurar que no se les secuestra, se les vende o se trafica con ellos."

(UNICEF. Convención sobre los derechos del niño)

¿Cuáles son los tres elementos que caracterizan a un abuso sexual contra niños/as y adolescentes?

- Diferencias de Poder: posibilitan controlar fisica o emocionalmente a la víctima;

- Diferencias de conocimiento: la víctima no puede comprender cabalmente el significado y las consecuencias potenciales de la actividad sexual;

- Diferencias en las necesidades satisfechas: el agresor busca satisfacer sus propios impulsos sexuales (Intebi, 2011).

Distintos profesionales de la salud y el derecho aconsejan que con la presencia de uno de estos componentes ya estaríamos hablando de un abuso sexual cometido hacia niños/as.

Algunos de los comportamientos sexuales que, para este trabajo, consideramos un abuso sexual cometido hacia niños, niñas y adolescentes son (Intebi, 2011, p. 29):

- Comportamientos sexuales sin contacto fisico:

- Comentarios sexualizados hacia el niño/a;

- Exhibición de genitales frente al niño/a;

- Voyerismo (espiar en la intimidad al niño/a);

- Exhibición de materiales pornográficos al niño/a;

- Inducción a que el niño/a se desnude o se masturbe delante del/a agresor/a;

- Comportamiento con contacto sexual:

- $\quad$ Tocamiento en las partes íntimas; 
- Inducción a que el niño realice tocamientos al agresor/a;

- Frotamiento de los genitales del/a agresor contra el cuerpo o la vestimenta del niño/a;

- Penetración digital o con objetos:

- Introducción de su dedo en vagina y/o ano;

- Inducción a que el niño introduzca su(s) propio(s) dedo(s) en vagina y/o en ano;

- Introducción de algún elemento en vagina y/o en ano;

- Inducción a que el niño/a se introduzca algún elemento en vagina y/o en ano.

- Sexo oral:

- Penetración peneana:

- Coito vaginal;

- Coito anal;

- Coito con animales.

¿Cómo las profesionales dan cuenta de que existe o existió abuso?

Las psicólogas argumentan que los signos y síntomas que indican la existencia de abuso sexual en niños y niñas son múltiples y variados y sus efectos van a depender de cada niño/a. El registro de los mismos y su valoración deben ser realizados por profesionales capacitados en la temática:

- Indicadores altamente específicos (Müller, 2011, pp. 48-49-50)

a. Físicos:

- Lesiones en zona genital y/o anal;

- Sangrado por vagina y/o ano;

- Infecciones genitales o de transmisión sexual;

- Embarazos;

b. Psicológicos:

- Relato del niño/a;

- Conductas hipersexualizadas y/o autoeróticas (no esperables para la edad);

- Coerción sexual hacia otros niños/as;

- Indicadores específicos asociados

- Pérdida del control de esfinteres. Enuresis, encopresis. 
- Manifestaciones en público de conductas erotizadas.

- Exhibicionismo de genitales, manoseos a otros.

- Trastornos psicosomáticos.

- Hemorragias, lesiones, mordeduras.

- Adicciones.

- Síntomas de apariencia psicopatológica.

- Miedos y terrores intensos.

- Trastorno de sueño, del habla.

- Preocupación excesiva por la higiene o arreglo personal.

- $\quad$ Abandono de hábitos, descuidos.

- (Entre otros)

- Indicadores en adolescentes

- Promiscuidad sexual, prostitución.

- Coerción sexual hacia otros niños.

- Drogadicción.

- Delincuencia.

- Conductas autoagresivas.

- $\quad$ Intentos de suicidio.

- Anorexia, bulimia. Obesidad.

- Indicadores en adultos/as

- Trastornos psiquiátricos graves.

- Disfunciones sexuales.

- Trastornos en la alimentación.

\section{Creencias erróneas}

En el manejo de la información concerniente a episodios considerados como delitos de índole sexual contra niños, niñas y adolescentes el corpus de creencias erróneas o del sentido común que circula es altísimo. Esto podría ser por el tipo de sociedad de corte patriarcal, machista, sexista en la que vivimos, o creencias que reforzaron con los años y hoy por hoy se cristalizaron en una serie de respuestas, justificaciones o discursos inverosímiles. Intebi recoge algunas de ellas y las resume así (Ídem, p. 41): 
- El abuso sexual infantil no es sinónimo de violación;

- El abuso sexual infantil no es sinónimo de incesto;

- El abuso sexual infantil no es sinónimo de penetración genital;

- El abuso sexual infantil no ocurre únicamente entre un niño o adolescente y un adulto;

- El abuso sexual infantil no es algo que cometan sólo los varones;

- Notificar lo sucedido, e incluso contar con pruebas de que ha ocurrido un abuso sexual infantil, no garantiza que las autoridades consideren que la notificación es veraz o que el responsable reciba el castigo que corresponde según la ley.

\section{Contexto Nacional}

Estas líneas fueron escritas a 79 días de la primera marcha \#NiUnaMenos que se realizó en los cuatro puntos cardinales del país. Luego de varios femicidios cometidos por varones y la puesta en agenda por los medios (Chiara Páez, Lucía Maidana, Taty Piñeiro, Melina Romero, Daiana García, Lola Chomnalez, Araceli Ramos, anteriormente Ángeles Rawson, Candela Rodríguez, entre otras cientos) percibíamos cierto clima de hartazgo desde las organizaciones que vienen denunciando esta violencia machista hacía tiempo. Los medios, por supuesto, espectacularizaron estas muertes, las fotos de las muertas se multiplicaron a montones, los testimonios de indignación circularon en todos los medios. Se podía palpar cierto cansancio que antes era, más bien, resignación.

La $\mathrm{RED}^{2}$ es, precisamente eso, una red que componen organizaciones militantes de todo el país que se nuclearon con el objetivo de luchar por los derechos de la infancia. Redes sociales como Facebook y tecnologías como Skipe (intercambio audiovisual) facilitaron su encuentro y organización sobre todo en lo que a distancias se refiere. Las organizaciones militantes que componen LA RED, si bien focalizan en la defensa de los derechos de la niñez, se hacen eco de las distintas injusticias que tienen

\footnotetext{
${ }^{2}$ En el apartado siguiente- descripción de las escenas comunicativas- hay una descripción más completa de esta organización.
} 
que ver con las violencias de géneros. Participan y organizan manifestaciones de pedido de justicia, participan en los medios a través de comunicados y conferencias de prensa, petitorios o cuando son invitadas/os en algún programa (tal es el caso de la TV Pública, Canal 9, C5N, TELEFÉ y América, hasta donde alcanzamos a relevar)

Si bien el abuso sexual -para este trabajo- es analizado y visto de manera específica, plantear y describir el contexto en el que estas líneas fueron pensadas y escritas no es un dato menor. Son los hilos muy finos que conectan estas violencias lo que denuncian. El abuso sexual, las violaciones, mutilaciones, marcas en los cuerpos de mujeres, niños, niñas, adolescentes e identidades trans feminizadas parecieran tener denominadores en común, parecieran ser el mismo tipo de agresor/a, las mismas modalidades, características, saña. Todo este contexto de ¿reflexión? y debate público fue arena fértil para pensar estas líneas. Entre tanta indignación, clima de hartazgo, marchas, movilizaciones que tuvieron epicentro en Buenos Aires pero replicaron a lo largo de todo el país surgieron estos cruces, ideas, sentires. Fueron el caldo de cultivo para pensar, reflexionar pero -sobre todo- sentir de qué hablamos cuando hablamos de dolor, de trauma, de miedo. Porque en comunicación, el contexto de enunciación dice mucho o más que el propio enunciado, y es en este contexto caracterizado por un clima enrarecido, ¿conmovido? por tantas muertes mediatizadas y casos de abuso sexual a niños y niñas (recordemos que por aquel entonces varios casos de abuso sexual fueron puestos en agenda: un jardín maternal en Belgrano, un colegio en San Telmo, el colegio primario Medalla Milagrosa en el barrio de Chacabuco, entre otros) es que esta tesis fue pensada.

Del mismo modo nosotras construimos relato sobre estos relatos. Entonces, en un clima de protesta social y debates públicos sobre si los casos de femicidio son un problema o no de seguridad social, el rol del Estado en el registro y seguimiento de casos, los avances en materia no solo legal sino simbólica, cultural y discursiva del manejo del tema, entre otros debates, son la arena de disputa y discusión sobre qué significa hablar y debatir sobre violencia hoy. 
"En 2008 mataron una mujer cada 40 horas; en 2014, cada 30; esos 7 años, los medios publicaron noticias sobre 1808 femicidios. ¿Cuántas mujeres murieron asesinadas por ser mujeres en 2015? No lo sabemos. Pero sí sabemos que tenemos que decir basta. En estos años, los femicidios dejaron cerca de 1500 niñas y niños huérfanos y algunos de ellos están obligados a convivir con los asesinos. El problema es de todos y todas. La solución hay que construirla en conjunto. Necesitamos sumar compromisos para cambiar una cultura que tiende a pensar a la mujer como objeto de consumo y descarte y no como una persona autónoma." 3

(Documento leído el 3 de Junio del 2015 en la Marcha del \#NiUnaMenos. Plaza Congreso $)^{4}$

Pero vamos a las cifras. No porque sean más confiables sino que suponen cierta representación del problema. En cifras globales y de la OMS, una de cada 5 mujeres y 1 de cada 13 varones declaran haber sufrido abusos sexuales en la infancia. Pero si hablamos del contexto local,

"Argentina carece de estadísticas oficiales respecto de la incidencia del problema en general, y menos aún en sus diferentes tipos. Los datos con los que contamos reflejan, en primer lugar, los casos que han sido atendidos en diferentes servicios de violencia familiar, o sea que se trata de niños detectados, con situaciones graves que han requerido atención especializada y en los que ha mediado, en general, una denuncia." (Bringiotti, 1999, p. 77)

María Inés Bringiotti es una de las referentes en el tema y si bien aseguró esto en 1999 sus estudios posteriores hasta el 2010 vinieron a reafirmar esto. Aún hoy no hay cifras oficial en materia de delitos sexuales, aparecen cifras estimativas pero lo conflictivo es relevar casos cuando la gran mayoría no son denunciados (sobre todo los abusos intrafamiliares).

\footnotetext{
${ }^{3}$ Datos relevados por la Organización no Gubernamental la Casa del Encuentro.

${ }^{4}$ Página 12 del día jueves 4 de junio. Recuperado el día 17 de septiembre del 2015. Disponible en $<$ http://www.pagina12.com.ar/diario/elpais/1-274193-2015-06-04.html>.
} 
Bringiotti, con investigaciones de corte más cuantitativo, y su equipo realiza relevamientos epidemiológicos sobre las cifras de víctimas de abuso sexual en la infancia desde 1994 con la creación del Programa Infancia Maltratada dependiente de la Facultad de Filosofía y Letras de la UBA. Las últimas cifras que arroja el equipo de Bringiotti son del trienio 2008/2010 y el relevamiento fue: por las universidades públicas la UBA en todas sus facultades que cuenta con el $80 \%$ de la matrícula entre todas las universidades públicas de Capital Federal; el IUNA (UNA) - Instituto Universitario Nacional de Arte - 5\% de matrícula y representante de carreras artísticas; Universidad de la Policía Federal $-1 \%$ de matrícula y como representante de las universidades del ámbito de las fuerzas armadas, que comprenden las universidades del Ejército, Naval, Aeronáutica y Policía, cubrieron entre las 4, el 4\% de la matrícula-. Dentro de las privadas, seleccionaron las universidades de Palermo, Maimónides, Salvador, Argentina de la Empresa y Ciencias Sociales y Empresariales. Todas ellas cubren el $17 \%$ de la matrícula privada. Recordemos que estas cifras nos darán un panorama de Capital Federal: se relevaron 2750 casos, que se corresponden con la matrícula por sexo, de la población universitaria $-61,4 \%$ femenina y $38,6 \%$ masculina -. Las edades iban desde los 18 años - CBC - a los 63 años - posgrado -, con una media de 22,8 años. Para el total de la población -2750 casos- el abuso asciende al 9\% del total - 247 casos - que corresponden el $11.9 \%$ al sexo femenino y $6,1 \%$ al masculino -. Es decir, se registra un 19\% de abuso sexual (Bringiotti y Raffo, 2010). Anteriormente $(2005 / 2006)$ este mismo equipo realizó un relevamiento en Capital Federal observándose un aumento de un $36 \%$ sobre los casos de malos tratos en general detectados anteriormente (la medición anterior fue en 1993/1994 con 1340 casos de niños o niñas que sufrieron algún tipo de maltrato), y un aumento del 3\% de abuso sexual, respecto a la medición anterior $(1,8 \%$ ) (Ídem). Recordemos que el recorte espacial/geográfico para este trabajo de campo se delimitó a AMBA (Capital Federal y parte de zona oeste de la provincia de Buenos Aires). 
Las cifras del Programa Las Víctimas contra las Violencias del Ministerio de Justicia y Derechos Humanos ${ }^{5}$ revelan estadísticas no más esperanzadoras: para el 2012, en niños, niñas y adolescentes (de 0 a 18 años) registraron 540 víctimas de las cuales 126 fueron forzadas a tener relaciones sexuales vaginales; 38 fueron forzados a tener relaciones sexuales anales; 34 fueron forzados/as a tener relaciones sexuales orales; 26 trataron de forzarlo/a a tener relaciones sexuales; 325 fueron tocados/as sexualmente por la fuerza; 12 fueron forzados/as a tener sexo con una tercera persona; 64 casos fueron "otros" (exhibicionismo, acoso, etc.) y 28 no recuerda ${ }^{6}$. Si bien Giberti aclara que no hicieron distinciones sexo genéricas, les interesaba ver el tipo de abuso en edades de 0 a 18 años en ámbitos familiares. Para el 2013 el número de víctimas de abuso y violación ascendió a 581 y se contabilizaron 379 por abuso sexual a niños, niñas y adolescentes.

El Programa no cuenta con cifras sistematizadas públicas de casos de abuso sexual a niños y niñas salvo las publicaciones, tanto en prensa como en trabajos, de su coordinadora (Eva Giberti) que las presenta a modo general con el objetivo de alarmar sobre el incremento de las cifras. Recordemos que este programa trabaja en territorio y de modo urgente: cuenta con brigadas móviles pendientes de los llamados al 137 (brigada móvil de atención a víctimas de violencia familiar) ${ }^{7}$ y acuden al lugar para asistir a las víctimas y sacarlas del peligro. Este programa sólo acompaña a la víctima hasta el momento de la denuncia, por esta razón no hacen tratamiento psicológico o de acompañamiento posterior. Un dato: aún si la víctima retira la denuncia, al ser penal la justicia está obligada igualmente a seguir con la investigación.

\footnotetext{
${ }^{5}$ El 13 de marzo del año 2006 se crea el Programa bajo la dirección de la Dra. Eva Giberti, dependiente del Ministerio del Interior. A partir del 10 de diciembre del año 2007 y debido a la asunción del señor Ministro Aníbal Fernández -anterior Ministro del Interior- como Ministro de Justicia, Seguridad y Derechos Humanos, el Programa se trasladó a la órbita de dicho Ministerio. Desde esa fecha hasta la actualidad el Programa está bajo la órbita de dicho Ministerio. El objeto del Programa consiste en atención a las víctimas de abusos o malos tratos, causados por ejercicio de violencias cualquiera fuese su naturaleza, en un ámbito de contención, seguridad y garantía de sus derechos. Asimismo el presente objeto incluye la lucha contra el maltrato, explotación y prostitución infantil. Tiene por objetivo principal la atención, acompañamiento y asistencia a las víctimas de violencia familiar y sexual. Posicionamiento de las mismas en un lugar activo que implique su decisión de colaborar en tanto responsabilidad ciudadana. Fuente: Programa las Víctimas contra las Violencias.

6 Fuente: Diario Página 12 del día 10 de febrero del 2013. Recuperado el día 22 de septiembre del 2015.

7 Cuentan, además, con dos brigadas específicas: Brigada Niñ@s: contra la explotación sexual comercial de niños, niñas y adolescentes y Brigada móvil de intervención en urgencias con víctimas de delitos sexuales.
} 
Lo llamativo de este despliegue (entre tantas) de cifras es que nadie puede dar respuesta a preguntas que hace años se vienen formulando: ¿incrementaron los casos de abuso sexual a niños, niñas y adolescentes o se denuncian más? ¿Es posible prevenirlo? ¿es posible "curar" esa ruptura cognitiva que marca a la víctima? ¿Qué es -en conclusión- la violación a una persona niño, niña? Y es que estas cifras no fueron analizadas, las investigaciones o relevamientos van hasta ahí nomás. Hasta la indignación pareciera. Desde la psicología si bien avanzaron sobre esta cuestión, es desde las ciencias sociales que buscamos aliados y diálogos. Incluso equipos que trabajan y son referentes en el estudio de la problemática de abuso, todas sus investigaciones terminan ahí: en la cifra. Pero esto no es casual, hay una preocupación casi constante por los números cuando de violencia hablamos. Preocupación no menor y de gran importancia a la hora de pensar políticas públicas, pero aquí no estamos (aún) para ese (gran) paso. En ciencias sociales, en esta tesis de doctorado estamos para reflexionar al respecto. Entonces, volvemos. Uno de los pedidos más urgentes que hacían las organizaciones que participaron de la marcha \#NiUnaMenos es un registro único de casos de femicidios en todo el país. Pedido que dos días después el Ministerio de Justicia y Derechos Humanos de la Nación terminó comunicando su creación ${ }^{8}$. Otra vez, la cifra acude no porque sean más confiables, sino que suponen cierta representación/imaginario del problema.

\footnotetext{
8 "El 5 de junio de 2015 quedó conformada la Unidad de Registro, Sistematización y Seguimiento de femicidios y de homicidios agravados por el género, a través de la Resolución $n^{\circ} 1449$, que contendrá los casos ocurridos en todo el territorio nacional. Mediante el registro, sistematización y seguimiento de información de estos casos se contribuirá al desarrollo de políticas públicas precisas en materia de prevención de violaciones a los derechos humanos específicos de las mujeres en general y femicidios (íntimo, no íntimo, familiar o infantil; vinculado o por conexión); sistémico (en el contexto de crímenes masivos); por trata o tráfico de migrantes; por prostitución; por mutilaciones sexuales y homicidios agravados por el género en particular (lesbofobia, transfobia). Si bien uno de sus objetivos es poder alcanzar registros cuantitativos para la elaboración de estadística oficial; también se podrá realizar un análisis cualitativo, que permita ver tanto si existieron intervenciones estatales anteriores a los homicidios (en los distintos niveles del Estado nacional, provincial y municipal), como cuáles fueron las respuestas institucionales recibidas y fundamentalmente qué hizo el Poder Judicial en el abordaje del caso (si hubo denuncias anteriores, como el abordaje del homicidio en sí; si caratuló como femicidio; si solicitó medidas de pruebas para conocer si había una historia de violencia previa, si hizo lugar a los pedidos de querellas y fiscalía, etc.)". Fuente: Portal Ministerio de Justicia y Derechos Humanos. Presidencia de la Nación.
} 
Todo esto estuvo (y está) sucediendo mientras escribo estas líneas. Es que en ciencias sociales los cambios -a veces- van más rápido que el pensamiento para comprenderlos. Y así, entre(medio) de tanto debate público y puesta en escena es que hicimos este recorte del problema y empezamos a tirar del hilo que se desprende del ovillo. Un ovillo que con cada nuevo tirón parece agrandarse más que achicarse y dicho sea de paso- no promete ser sencillo de desenredar. 


\section{Primera Escena/ Situación Comunicativa:}

La ONG

Con el objetivo de mantener en absoluta reserva y cuidado la identidad de los sujetos que intervienen en esta investigación es que decidimos no dar datos precisos de ubicación, temporalidad y nombres al lector de este material sobre el trabajo de campo.

Esperemos comprenda la delicadeza que exige el manejo de discursos que tienen que

Esta ONG está ubicada en provincia de Buenos Aires y cuenta con varios programas que van desde la investigación de problemáticas como el abuso sexual a niños y niñas, programas de asistencia y acompañamiento a jóvenes en situación de vulnerabilidad socio penal, hogar asistencial de niñas y jóvenes de 12 a 21 años, entre otros. Además de estos programas, realiza asistencia y terapia a quién así lo demande especializándose en distintas problemáticas como ser drogadicción, bulimia, anorexia y trata. Que sean especialistas en asistencia de estos temas en particular veremos que no es un dato menor, es esta característica lo que hace especial su abordaje, tratamiento, detección pero, sobre todo, su enunciación.

Sus inicios se remontan a, "1997 como iniciativa de un grupo de terapeutas que con vocación de servicio deciden brindar a la comunidad en forma gratuita su trabajo. En 1998 esta tarea, que por medio de boletines llegaba a las escuelas, se vio desbordada por la cantidad de pacientes y, en vistas de nuevas incorporaciones, hacen un llamado a jóvenes recién egresados de las carreras de Psicología, Psicopedagogía, Fonoaudiología y Trabajadores Sociales a fin de conformar un equipo multidisciplinario que atienda las demandas comunitarias en modalidad pasantía. El 9 de abril de 1999 se constituye la primera comisión que aprobará el Estatuto Social de la Asociación Civil" (Sitio Oficial). 
Tanto esta organización como otras de esquemas y dinámicas similares trabajan siempre con denuncia penal y civil de por medio, esto es en el marco de la normativa sobre violencia que obliga a denunciar los posibles casos de abuso sexual de los que puedan ser víctimas niños, niñas y adolescentes. Es decir, en este contexto, cuando hay niños, niñas y adolescentes involucrados la denuncia ante la autoridad judicial tiene carácter obligatorio. En Argentina la acción siempre será preventiva y de protección de la víctima más que condenatoria del victimario, se priorizará poner a salvo a ese niño, niña o adolescente y después se procederá a la sanción o al procedimiento judicial.

“Desde 1992, la mayoría de las provincias y la ciudad de Buenos Aires han dictado leyes locales de protección contra la violencia familiar. En general, no han establecido regímenes represivos sancionatorios sino que han instaurado un sistema de amparo, protección y/o tutela a las víctimas del maltrato infantojuvenil. Éste busca, en primer lugar, el cese de la situación de riesgo y de la violencia que reciban dichas víctimas, mediante la adopción de medidas urgentes, provisorias y mutables; y en segundo lugar, establece instancias terapéuticas para la rehabilitación de las víctimas, del grupo familiar y de la persona victimaria [...].” (Viar en Volnovich, 2006, p. 58)

Ya sea por derivaciones de otras organizaciones, por iniciativa personal o en trabajo en articulación con otras organizaciones esta ONG trabaja solo con evaluación psicodiagnóstica. La evaluación psicodiagnóstica es realizada a cualquier persona que llegue a la institución y quiera o deba tratarse, sea cual fuere el motivo tenga o no que ver directamente con la violencia sexual. Es el proceso de recolección e interpretación de toda la información recabada sobre la persona a los fines de efectuar el diagnóstico psicológico y "detectar" el "problema". "El objetivo de la evaluación es que los profesionales intervinientes puedan recoger información y formarse una opinión acerca de: 
a. La fuente y el significado de los relatos o descripciones aportados por los niños o adolescentes;

b. los comportamientos observados, $y$

c. cualquier otro elemento que haya despertado sospechas de posibles comportamientos abusivos." (Ídem, p. 96)

En el caso de niños, niñas y adolescentes la evaluación siempre es realizada y grabada en cámara gesell, la cual pertenece a esta ONG.

Cuando los casos que ingresaron fueron a través de un pedido de Fiscalía la Evaluación va a tener características periciales, es decir, la traducción es pensada en función de estos destinatarios en particular: juez, abogado y fiscal. "La evaluación de las sospechas de abusos sexuales consiste en un proceso sistematizado de recolección de la mayor cantidad posible de información como para afirmar o descartar la ocurrencia de las agresiones sexuales" (Intebi, 2011, p. 96). A diferencia de una evaluación común, aquí las sospechas de abuso ya vienen desde la organización que hace la derivación (en nuestros casos desde Fiscalía a través de una denuncia civil y/o penal) y es con esta sospecha que empieza la búsqueda o descarte de los indicadores. Estos "indicadores" se traducen en la articulación de pistas para obtener un panorama de lo que sucedió.

“Cuando se evalúa una sospecha de abuso sexual infantil desde el punto de vista forense, el entrevistador intenta, desde una posición neutral, investigar y valorar la posibilidad de que hayan ocurrido ciertos hechos, planteándose desde el principio explicaciones alternativas e intentado obtener detalles que corroboren los testimonios de los niños." (Intebi, 2011, p. 97)

Entonces, dependiendo de los objetivos de estas evaluaciones los "resultados" sirven para orientar una intervención terapéutica y/o colaborar en una decisión judicial. 


\section{La cámara secreta}

La cámara gesell de esta organización en particular es un cuarto ambientado para niños/as y jóvenes, donde cada mobiliario, colores, juguetes y material didáctico tiene una finalidad concreta dentro del espacio. Cuenta con dos baúles de juguetes seleccionados por edades, material didáctico (papeles, colores, temperas, lápices), mobiliario para niños y niñas (mesa y sillas pequeñas y de colores) y para jóvenes (mesa y silla de un tamaño más bien del que una dispone en su casa). El vidrio espejado es un cuadrado no muy grande (del tamaño del que una tiene en su baño), que divide la cámara gesell de una oficina pequeña donde se encuentra la computadora y la grabadora que registra todo el desarrollo de la relación terapeuta -niño/a- joven.

El objetivo de realizar las evaluaciones aquí es mantener lo más tranquilo posible al niño, niña y joven que está en ese momento, simula su "hábitat natural" si hablamos en términos del mismo Gesell (1967).

En la Argentina el impulsor de la ley que da cuerpo y vida a la cámara gesell es Carlos Rozanski, presidente del Tribunal Oral N1 de La Plata.

“Con fecha 04 de diciembre de 2003 se sancionó la ley $N^{\circ} 25.852$ mediante la cual se incorporó al Código Procesal Penal de la Nación el art. 250 bis. Mediante dicha norma se estableció que los menores de 16 años presuntamente víctimas de delitos sexuales sólo serán entrevistados por un psicólogo especialista en niños y/o adolescentes designado por el tribunal que ordene la medida, no pudiendo en ningún caso ser interrogados en forma directa por dicho tribunal o las partes; en un gabinete acondicionado con los implementos adecuados a la edad y etapa evolutiva del menor. También la norma establece que a pedido de parte o si el tribunal lo dispusiera de oficio, las alternativas del acto podrán ser seguidas desde el exterior del recinto a través de vidrio espejado, micrófono, equipo de video o cualquier otro medio técnico con que se cuente." (Viar, 2015, p. 3)

Esta normativa permitió flexibilizar y anteponer el resguardo y cuidado de las víctimas en pos de no revictimizarlos con preguntas que puedan herir su sensibilidad. 
Que la ley contemple la actuación de profesionales capacitados en la temática (psicólogo/a especialista) supone un correcto manejo no sólo de la problemática, sino un manejo más ajustado del discurso, la corporalidad, gestos y todo lo que tenga que ver con la actuación protocolar. El trato con niños, niñas y adolescentes que atravesaron la experiencia del abuso sexual no debiera ser de cualquier manera, ni dicho de cualquier forma: el discurso, las prácticas corporales y gestuales son traducidos. "[...] no puede desconocerse el avance que significó el uso en sí de la Cámara Gesell ya que permite entre otras ventajas- un registro riguroso de la entrevista, la documentación visual de los gestos y las expresiones faciales, la revisión posterior por otros profesionales y una forma de capacitación continua para los operadores" (Ídem, p. 11). El dato del registro audiovisual no es menor, permitirá la visualización posterior, previa aprobación del juez en la causa, cuantas veces sean solicitadas sin la necesidad de que el niño, niña o adolescente vuelva a pasar por la situación de entrevista.

Hay autores que no solo señalan las ventajas de contar con la cámara gesell en casos como éstos, sino que exponen las desventajas de la utilización de la misma. "La cámara gesell o sus sucedáneos si bien pueden ayudar mucho a la revelación y evitar posteriores revictimizaciones, ponen al niño frente a una cámara de tv, lo que incide decididamente en su actitud frente al perito" (Volnovich, 2006, p. 125) K. Kuehnle (2003 en Volnovich 2006) detalla las siguientes ventajas y desventajas de la videofilmación:

\section{"Ventajas. Provee:}

a. un registro riguroso de la entrevista;

b. la documentación visual de los gestos y las expresiones faciales que acompañan los enunciados verbales del niño;

c. un registro visual y verbal que puede ser revisado años más tarde por otros profesionales;

d. $\quad$ una reducción del número de entrevistas por parte de otros profesionales;

e. una forma de capacitación continua para los entrevistadores;

f. una ayuda efectiva para lograr una aceptación de lo ocurrido por parte del ofensor;

g. una herramienta efectiva para ayudar al padre no ofensor o al padre acusado a comprender lo que ocurrió o lo que no ocurrió." (Ídem, p. 125) 
En cuanto a las desventajas:

a. "el proceso es intrusivo, y el niño puede mostrarse reticente a develar la información;

b. las complicaciones logísticas de la obtención de un equipo y un cuarto especial pueden hacer que su uso sea prohibitivo;

c. la calidad técnica del video puede ser pobre;

d. puede ocurrir la pérdida de datos por el mal funcionamiento del equipo;

e. la entrevista videograbada puede ser utilizada para poner en tela de juicio al niño;

f. la técnica del entrevistador puede transformarse en el centro del caso más que la sospecha de abuso sexual en sí;

g. la videograbación puede caer en manos inapropiadas, como las de los medios de comunicación." (Ídem, p. 126)

El niño/a o adolescente siempre debe ser informado que lo están grabando y quiénes lo están escuchando. Esto tiene que ver con el cumplimiento de Derechos Universales de empoderar y dar participación a los principales involucrados, tener presente sus decisiones y hacerlos partícipes del proceso entero.

Por las características del delito de abuso sexual, la prueba por excelencia es la misma víctima. En situaciones como éstas que se tratan de niños, niñas y adolescentes, no pueden participar de un interrogatorio como lo haría un adulto, la mayoría de los casos los delitos ocurren dentro del ámbito familiar, lo cual provoca una enorme confusión. En ese contexto es imposible pensar que pueden presentarse como un testigo tradicional. 
“Veinte años atrás tuvimos el caso de una menor con un retraso mental que había sido abusada. En el juicio, uno de los jueces empieza a hacerle una serie de preguntas a la chica sobre el hecho que francamente eran terribles. Cuando analizo el caso había algo que no me terminaba de cerrar, y me doy cuenta de que esa chica no tenía por qué estar ahí sentada frente a los jueces. Es entonces cuando descubro eso que me pongo a trabajar en el proyecto de ley que luego derivó en la creación de la Cámara Gesell, mediante la que se prohíbe a los jueces interroguen a menores... es el único país del mundo que lo aplica." (Juez Rozanski en entrevista) ${ }^{9}$

\section{La Evaluación Psicodiagnóstica (EP)}

En el caso concreto de esta organización, la evaluación psicodiagnóstica es realizada a lo largo de seis a ocho encuentros con la especialista a los fines de lograr un diagnóstico de la situación psíquica inicial de ese niño, niña o adolescente. Una vez concluidas las sesiones la profesional elabora un informe final de carácter y formato forense (ya que se eleva a Fiscalía), el mismo es presentado primero a la coordinación de la ONG quién debe aprobar y elevar al órgano pertinente en el caso.

Las grabaciones de las sesiones, en caso de ser necesarias en un futuro, son utilizadas en instancia judicial. El objetivo de grabar a todos los niños, niñas y jóvenes que pasan por la cámara es solo preventivo, ante una denuncia no pasan de nuevo por las mismas preguntas, esto es respetando la premisa máxima de la institución que es no revictimizar a las víctimas. Esta organización no realiza testimoniales que, a diferencia de la evaluación, es un interrogatorio que hacen al niño o niña en cámara gesell, pero con el objetivo de crear un procedimiento protectorio para su declaración cuando ha sido víctima o testigo de un delito de índole sexual o peligra la vida.

\footnotetext{
9 Diario BAE suplementos, martes 22 de octubre de 2013 en $<$ http://www.proteccioninfancia.org.ar/node/860>. Recuperado el día 07/09/2015.
} 
La diferencia con la evaluación que realiza la institución es el respeto por los tiempos del niño/a para contar/hablar del porqué está ahí, hay una psicóloga entrenada que lo está escuchando y del otro lado del vidrio espejado nadie lo está mirando (salvo en casos particulares): son ella y el niño/a nada más. En cambio, en la testimonial, es un fiscal, juez o abogado quien dicta las preguntas a la psicóloga por medio de un auricular en tiempo real que coincide con el juicio, quien a su vez debe "dar con el testimonio". Del otro lado del espejo están todas las partes intervinientes en el juicio y el niño/a sabe que lo están escuchando. Existen casos donde es el fiscal quien realiza las preguntas al niño o niña, completamente violatorio de lo que establece la ley al rezar que solo profesionales idóneos en la materia pueden hacer las preguntas al niño.

Como decíamos, la organización con la que trabajamos solo realiza evaluación psicodiagnóstica, única en la región por este trabajo. Este modo de accionar tiene que ver con medidas proteccionistas que tiene la ONG para con sus "pacientes" dirección sostienen que es la única manera que encontraron para no someter a preguntas incómodas y con escaso tiempo a los/as niños/as. En la EP trabajan con los tiempos del niño, niña o adolescente en sesiones de una hora de seis a ocho encuentros, esto da un margen a la terapeuta y el/la paciente a que se conozcan, charlen sin necesidad de meter preguntas apresuradas sobre la experiencia en cuestión. De acuerdo a la edad de los niños, niñas y adolescentes y las causas por las que ingresa a la ONG la dirección asigna los casos a determinadas profesionales, las mismas están preparadas y entrenadas dentro de la misma institución para trabajar bajo las citadas condiciones. Es a partir de estos encuentros que van a determinar cómo está el niño, niña o adolescente hasta ese momento, si hay sospechas de abuso o violencia esta EP va a "disipar" esas dudas. Recordemos que la sospecha de abuso, violencia o maltrato es solo inicial, la evaluación va a venir a confirmar o a descartar esta sospecha.

\footnotetext{
${ }^{10}$ Éste es el término con el que las terapeutas se refieren a los niños, niñas o adolescentes que tratan.
} 
La "sospecha" de abuso se traduce en:

a. “alguna persona ha detectado indicadores en su comportamiento o en su salud;

b. los niños han realizado algún relato o descripción de situaciones que generan dudas, $y / o$;

c. se detectaron indicadores de comportamientos sexuales inadecuados en personas sospechadas de haber cometido las agresiones sexuales." (Intebi, 2011, p. 95)

La denuncia en estos casos es siempre obligatoria, si todavía no fue hecha por los tutores legales, familiares, miembros de la comunidad escolar, padres o alguna otra persona que toma contacto con el niño, niña o adolescente la efectúa la misma organización.

\section{La Denuncia}

En sentido técnico la denuncia es "todo acto procesal mediante el cual se da conocimiento a la autoridad competente por escrito o verbalmente, sin necesidad de patrocinio jurídico, del hecho contrario a la ley, para que aquella proceda a la averiguación y la protección" (Viar en Volnovich, 2006, pp. 58-59). La misma cumple una doble función: protectora y preventiva. Protectora frente al peligro o riesgo que corre el niño, niña y/o adolescente y preventiva porque debe evitar posibles nuevos riesgos y daños.

Como decíamos, en Argentina la normativa privilegia la protección, cuidado y asistencia de la víctima antes que la búsqueda de sanción del victimario. En el caso de niños, niñas y adolescentes esta urgencia es aún mayor, ubicando entre las prioridades de la ONG mantener a salvo a ese niño/a. Si ingresa a la ONG bajo sospecha de abuso sexual y aún no fue efectuada la denuncia, es la dirección de esta organización quién lo hace. "[...] la normativa privilegia la denuncia ante los organismos judiciales proteccionales y tutelares, que buscarán y privilegiarán el amparo de la víctima por sobre la sanción del victimario" (Viar en Volnovich, 2006, p. 57). 
Esta sospecha sin denuncia puede ser de parte del gabinete psicopedagógico de la escuela del niño o niña por ejemplo, derivado de otras profesionales, por "malos comportamientos" en la escuela y recomendación de asistencia psicológica, problemas de aprendizaje... las posibilidades son muchas y reciben niños y niñas desde distintos lugares y por diversos motivos. Veremos líneas adelante como este ingreso y motivo es codificado en clave institucional y su posterior "tratamiento". Por el momento esto: los motivos de ingreso a la ONG por tratamiento pueden ser desde distintos lugares y por diversos motivos. La EP va a determinar qué tipo de tratamiento necesita ese paciente.

"El artículo 72 del Código Penal prevé que las personas que son víctimas de delitos sexuales pueden optar entre iniciar y proseguir una acción criminal o no. Cuando las víctimas son niñas, niños o adolescentes, la responsabilidad de tomar esa decisión recae en sus representantes legales, en la mayoría de los casos el padre y la madre. Ahora bien cuando:

a. La víctima fuere menor abandonado/a;

b. El delito fuere cometido presumiblemente por sus padres o representantes legales, e incluso cuando hay algún tipo de complicidad por parte de éstos;

c. Como consecuencia del delito, resultare la muerte de la víctima;

d. Como consecuencia del delito, la víctima resultare con lesiones gravísimas, esto es, que se produjere una enfermedad mental o corporal, cierta o probablemente incurable, la inutilidad permanente para el trabajo, la pérdida de un sentido, de un órgano, de un miembro, del uso de un órgano o miembro, de la palabra o de la capacidad de engendrar o concebir;

e. El delito tipificado fuere el de corrupción de menores, se procederá de oficio; es decir, el delito deja de ser de instancia privada y rige la obligación de denunciar por parte de los profesionales de la salud y/o de los funcionarios públicos, ya que el estado de indefensión del niño o niña víctima justifica dicha resolución." (Viar en Volnovich, 2006, pp. 56, 57)

En Buenos Aires y según la Ley 12.569 el equipo de salud puede realizar la denuncia en: Tribunales de Familia, Juzgados de primera instancia civil y comercial, Tribunales de menores, Juzgados de paz letrados. En Capital Federal ante Defensorías nacionales de menores e incapaces, de turno. 
La jurisprudencia de la ciudad de Buenos Aires referida a la aplicación de la ley 24.417 señala que "bastan la sospecha del maltrato ante la evidencia psíquica o física que presente el maltratado y la verosimilitud de la denuncia, para que el juez pueda ordenar medidas cautelares" (Ídem, 2006, p. 64). Es así que ante la sospecha y a partir de esta es obligación legal y moral del equipo de salud denunciar. En otros países para llegar a la instancia de denuncia el grado de certeza debe ser "causa razonable" para creer o sospechar. No denunciar ante una sospecha de abuso o maltrato constituye (para nuestra normativa) un acto de mala praxis, de negligencia y abandono de los deberes a cargo de quién debiera cuidar a ese niño/a o adolescente en ese momento. Bien conocido es el caso -año 2000- de una madre que denuncia en instancia civil por mala praxis a la psicóloga de su hija de cinco años en Ciudad de Buenos Aires, la misma es acusada de evidenciar indicadores de abuso sexual (dibujos, comportamientos) y no dar aviso ni a la madre ni hacer la denuncia correspondiente por sospechas. Con el tiempo la madre, por sí sola, descubre que su hija está siendo abusada hacía mucho tiempo por su progenitor y al encarar a la terapeuta la misma trata de convencerla de no hacer la denuncia ${ }^{11}$. Si bien el abusador fue condenado a 3 años de prisión por la Justicia Penal, este caso fue la bisagra para empezar a pensar los casos en que el secreto profesional debe ser levantado y replantearse las obligaciones y deberes de un profesional a cargo de la salud de una niña.

Esta obligación de denunciar tiene una doble responsabilidad tanto legal, como civil amparada y obligada por el Código de Ética de la Asociación de Psicólogos de la República Argentina. Es a raíz de esta obligación que se deriva una posible acusación o denuncia por mala praxis en caso de no haber cumplido con las funciones del profesional. El Código de Ética de los/as Psicólogos/as establece un marco orientativo para trazar conductas y, a la vez, una valoración no solo del accionar profesional sino de la culpa profesional. Es decir, esta normativa básicamente otorga un estatus legal a disposiciones éticas que establecen y ordenan comportamientos profesionales que los psicólogos deben respetar. Con respecto a la Responsabilidad Profesional y Científica en su apartado c el Código de Ética de la Asociación de Psicólogos de Buenos Aires reza:

\footnotetext{
${ }^{11}$ Nota diario Perfil, recuperada el día 09/09/2015 < http://www.perfil.com/sociedad/Las-denuncias-pormala-praxis-psicologica-evidencian-el-vacio-legal-de-la-profesion--20070219-0028.html >
} 
"Los psicólogos mantienen normas profesionales de conducta, clarifican sus roles y obligaciones profesionales, asumen la responsabilidad apropiada, y adecuan sus prácticas a las necesidades de las diferentes poblaciones en la medida de lo posible."

En el caso del Código de Ética de la Federación de Colegios de Psicólogos de la República Argentina en su punto 3.1.1 "Los psicólogos deberán ser conscientes de la posición asimétrica que ocupan frente a sus consultantes y no podrán hacer uso de su influencia más que con fines benéficos para estos." Estas, entre otras normativas, son un paradigma de conductas que el profesional debe seguir, fueron escritas en forma amplia y general aplicables a cualquier contexto regional y con las particularidades que amerita.

\section{Las profesionales}

Debido al sistema de pasantías con la que cuenta la organización el número de profesionales varía según la época del año. Hay momentos en que cuentan con un plantel de profesionales mucho mayor debido al número de pasantes que fueron incorporadas o en los períodos de entrenamiento cuando es preparado el equipo de salud para determinados casos (en los casos de abuso sexual, por ejemplo, las profesionales reciben una preparación especial dependiendo de la edad de la víctima, el grado o tipo de abuso y la relación víctima-victimario) Hay épocas en que baja la cifra de profesionales, algunas dejan la organización y deciden migrar a otras donde la paga es mayor (recordemos que al ser un sistema de pasantías el entrenamiento es constitutiva de la formación). Vale mencionar que uno de los desafíos con los que cuenta la organización es mantener un equipo estable de salud, la circulación de pasantes y personal es elevada (actualmente son 40 pasantes ad honorem) y es constante el recambio de profesionales. El cambio a otro lugar de trabajo donde la paga sea mejor o más gratificante, la distancia con respecto a la Capital, el desgaste que estas problemáticas significan, son algunos de los motivos por los cuales deciden dejar esta ONG. 
El equipo es interdisciplinar y cuenta con abogadas, trabajadoras sociales, profesionales de la educación, musicoterapeutas y -durante dos años- contó con una comunicadora social oriunda de Misiones. Cuando llega un caso a la organización (siempre hay una lista de espera de meses) debido al tipo de delito que representa, la gravedad, si la justicia está o no interviniendo, si hay una orden del físcal o peligra la vida del niño/a la dirección (por medio de su coordinadora) asigna el caso a determinadas profesionales. Una vez por semana el equipo que trabaja en abuso sexual es asistido y supervisado por una psicóloga más experimentada y capacitada en calidad de "supervisiones". Estas supervisiones son encuentros semanales con la supervisora asignada quien hace un seguimiento de los casos, orienta si hay complicaciones, recomienda lecturas o ayuda a encauzar a las psicólogas con menos experiencia. Esta instancia es de encuentro grupal en el que exponen ante todas como va su caso. Por ejemplo, ante la ausencia del relato de un niño o niña (no hay relato de abuso), ideas para juegos alternativos, evaluaciones, test y todo lo que pueda a ayudar al/la paciente.

La mesa de estudios sobre la Problemática del ASI (Abuso Sexual Infantil) se inició en el 2012 como parte de las actividades extra asistenciales de la ONG, es un equipo que se conformó con el objetivo de producir material científico pertinente a los estudios en Abuso Sexual Infantil. Es interdisciplinario porque responde a una mirada compleja y completa de la problemática, que atraviesa no solo al campo de la psicología y el trabajo social sino a otras como ser la educación y la comunicación. Esta iniciativa surgió desde la dirección y fue ante la complejidad e incertidumbre que significa trabajar esta problemática: los casos y el accionar de la Justicia, los círculos de revictimización, el tratamiento de los medios masivos de comunicación y el rol de otras organizaciones como ser las escuelas, los centros de salud, la familia, etc.

Cuando aterricé en Buenos Aires, y días después a esta localidad, el equipo recién estaba siendo pensado, habían abierto la convocatoria para reunir profesionales interesados en la temática sin importar de qué formación venían, esto de por sí era interesante. El proyecto a formar parte de un equipo que aborda el abuso sexual sin importar qué formación tenías prometía debate. Me inscribí. En el período en el que estuve fueron varios las y los profesionales que pasaron por esa mesa interdisciplinar que terminó por disminuir su producción en pos de atender las urgencias que una ONG con estas características demanda. Nos reuníamos una vez por semana dos horas para discutir los casos que en ese momento las profesionales estaban atendiendo, dudas y 
opiniones sobre cómo encarar un tratamiento, ideas para publicar, congresos, trabajo y lectura con materiales varios (libros, revistas, papers). A veces (pero en realidad fueron la mayoría de los encuentros) el grupo funcionaba como catártico: de repente las terapeutas utilizaron el grupo como un espacio donde canalizar frustraciones, miedos y anhelos que la labor con niños, niñas y adolescentes desprende. Por supuesto que el llanto silencioso o ruidoso -siempre presente- fue una especie de hilo conductor, pareciera que todas tenían una angustia contenida. Un dolor que compartir. Las historias de vida de las chicas asomaron, los motivos por los que trabajan esa problemática en particular y las repercusiones que eso tenía en sus cuerpos y mentes. Si bien mi paso por este grupo de estudios fue corto (dos años) pude notar algunas particularidades y los usos que hicieron de este grupo. No logramos producir material científico en cantidadsolo algunas presentaciones a congresos e ideas para publicar- pero (y páginas siguientes trataré de explayarme en este punto) tuvo una función distinta y quizás vital para las terapeutas: encontrarse. Y esto en palabras de las mismas psicólogas, el grupo que tenía por objetivo producir material académico sobre el ASI se convirtió en (la mayoría del tiempo) la excusa para juntarse y "soltar todo".

Hay un dato interesante con respecto al equipo de salud de esta organización: son todas mujeres. Si bien hay programas que están a cargo de varones psicólogos, este equipo en particular de asistencia a víctimas de abuso sexual es conformado en su totalidad por mujeres. Ante la pregunta a la directora por la falta de varones dio por toda respuesta: "no nos duran". No es que no haya habido varones terapeutas, pero no son los que se quedan durante la totalidad de la pasantía.

\section{El Secreto}

“Los psicólogos tienen una obligación primordial y toman las precauciones razonables para respetar los derechos a la confidencialidad de aquellos con quienes trabajan o consultan, reconociendo que esa confidencialidad está establecido en la Ley del Ejercicio Profesional, por reglas instituciones y/o por relaciones profesionales o científicas" (Código de Ética de la Federación de Colegios de Psicólogos de la República Argentina). 
El secreto profesional es la obligación que tiene el profesional de mantener en absoluta reserva datos, testimonios, sucesos o referencias sobre las personas con las que trabaja o las que están en ese momento bajo su cuidado. Son contadas las oportunidades en que los psicólogos pueden dar a conocer información confidencial sin el consentimiento informado de la persona,

“a) Cuando el psicólogo ha sido comisionado por autoridad competente. b) Cuando se trate de menores de edad y sus padres o las personas a cuyo cargo se encuentran, necesitan ser informados para el mejor tratamiento de los menores. En este caso, la información deberá suministrarse sólo dentro de lo que fuera estrictamente imprescindible al efecto indicado, e informado de ello al menos, toda vez que esto fuera viable. c) Cuando el psicólogo actúe en una empresa, escuela, tribunal y otra institución, al rendir informe sobre las personas que se le envíen para examen o evaluación, lo que requiere de todas maneras -quien estas personas conozcan y acepten el hecho de que se trata de una evaluación (Excepción hecha -en lo que hacer a la aceptación de una evaluación- de aquellos casos en los que, por determinación judicial, ésta es compulsiva. d) Cuando se trata de evitar la comisión de un delito y/o evitar los daños derivados del mismo." (Ídem)

En cuanto al Código de Ética de la Asociación de Psicólogos de Buenos Aires reconoce la posibilidad de romper con el secreto profesional cuando "así lo exija el bien del propio consultante, debido a que este, por causas de su estado, presumiblemente haya de causarse un daño o causarlo a otros." Es decir, no solo están obligados a denunciar cuando toman conocimiento de que está en peligro la vida de ese niño, niña o adolescente, sino que su código de ética así lo estipula como obligación.

En esta ONG cada vez que los indicadores de abuso son claros, las terapeutas no solo pueden sino que están obligadas a romper con el secreto profesional para denunciar. Esta obligación les trajo no pocos problemas. Para empezar han tenido que atravesar varias denuncias de mala praxis por no respetar su propio Código de ética donde exige absoluta reserva de los datos, como veremos líneas adelante, esta normativa -que parece ser muy clara- contempla excepciones pero sigue dependiendo de un juez para su resolución favorable. Está puesto en juego el mismo concepto de "peligrosidad" 
y si la ocasión merecía romper con el secreto profesional o no. Cuando hay una denuncia penal y civil de por medio fue la dirección de la ONG quien recibió demandas por dudoso criterio de evaluación (ponen en duda la batería de test que utiliza la profesional para dar cuenta del abuso), mala praxis, inexperiencia de la profesional o la “incapacidad” del niño, niña y/o adolescente por narrar el hecho y su única intérprete sea esa profesional. Hubo ocasión en que el juez llamó a la profesional para que salga de testigo a favor de la víctima y por medio de una orden del mismo la profesional pudo exponer su experiencia con esa víctima en evaluación. Recordemos que sólo por orden de un juez competente en la causa las profesionales pueden responder a las preguntas de las partes intervinientes. Cuando alguna de las profesionales es llamada a declarar, la dirección es quién las prepara para enfrentarse al tribunal: cómo responder, hacia donde mirar, que expresiones evitar. Son bien conocidas las estrategias de la defensa del victimario en busca de huecos o fallas en el relato de la profesional, con intención de invalidar las pruebas de abuso en su contra y que fueron sistematizadas en evaluación o pericial. 


\section{Segunda escena/situación comunicativa:}

\section{El Grupo}

Cuando conocí a Omar, uno de los miembros fundadores de este grupo autodenominado de ayuda de pares ${ }^{12}$, faltaba todo por hacer, había puras intenciones y ganas. Omar fue un día a la ONG, a una de las reuniones que teníamos los Miércoles con el equipo de ASI, la directora lo había invitado con intenciones de armar en algún momento la pata militante que faltaba en la ONG en materia de lucha por los Derechos de la Infancia. Con intenciones encontradas, Omar decide viajar a provincia de Buenos Aires y asistir a esta primera reunión para trabajar con nosotras.

El ambiente que involucra a militantes, psicólogas/os, organizaciones y víctimas de violencia y abuso sexual es relativamente chica en el AMBA (Área Metropolitana de Buenos Aires). Hace años vienen consolidando una Red no sólo de asistencia, asesoramiento sino de encuentros, congresos, simposios y marchas (pedidos de justicia). Esta cercanía con todos los sectores que involucran a la problemática, facilita que "entre nosotros/as" nos conozcamos. Es así que, para algunas, Omar ya era conocido en "el ambiente". Su caso comenzó a escucharse fuerte debido a una serie de notas periodísticas en diarios de tirada nacional como Página 12 y Clarín. Abusado por un cura en un colegio católico del barrio porteño de San Telmo, colegio al que asistió hasta los 17 años, Omar dejó conocer su caso como estrategia para llevar a su abusador a la cárcel. A raíz de su denuncia otros ex compañeros y ex alumnos denunciaron al mismo cura por abusos sexuales reiterados cometidos dentro del establecimiento educativo. Para el momento en que conocí a Omar su caso aún no era muy conocido, pasarían varios meses más hasta que la condena efectiva al cura salga a la luz y litros de tinta empiecen a correr sobre reiterados casos de abusos sexuales cometidos en distintas escuelas de la ciudad de Buenos Aires. Como bien sabemos, la agenda mediática a veces hace concesiones. Para ese momento, Omar llevaba adelante una lucha casi silenciosa con otros ex compañeros del colegio de San Telmo.

\footnotetext{
${ }^{12}$ Las especificaciones del funcionamiento de un grupo de ayuda de pares están en el apartado siguiente.
} 
Pero volvamos. Ese día (yo tenía registro de Omar solo a través de notas en Página 12) presentó su idea de fundar un grupo de ayuda de víctimas sobrevivientes de abuso sexual. La idea inicial era crear un grupo de contención dónde pudieran expresar sus experiencias con respecto al abuso que sufrieron en algún momento de sus vidas, la mayoría durante sus infancias. A lo largo del tiempo esta idea inicial varió y el grupo terminó convirtiéndose en otra cosa, siempre con el aporte de sus miembros y con la experiencia en su haber. Pero eso sucede más adelante, por ahora Omar sólo había llegado a la ONG para conocer al equipo y empezar a pensar un grupo de ayuda para y desde las mismas víctimas de abuso sexual. 
Victimas, Sobrevivientes y Militantes ${ }^{13}$

¡El Abuso sexual infantil existe! Somos sobrevivientes y adult@s víctimas de Abuso Sexual Infantil y Adolescente. Estamos comprometid@s con la defensa de los derechos humanos de niñas, niños y adolescentes. Podemos escucharte y queremos ayudarte. Te esperamos, acercate.

- 1 de cada 4 niñas es abusada sexualmente antes de cumplir 18 años.

- $\quad 1$ de cada 6 niños es abusado sexualmente antes de cumplir 18 años.

- $\quad$ Entre el 30\% y el 40\% de las víctimas son abusadas por un miembro de la familia.

- $\quad$ Otro $50 \%$ son abusadas por alguien fuera de la familia, pero a quién conocen y en quién confían.

- $\quad$ La edad media de los abusos sexuales denunciados es de 9 años.

- $\quad$ Las falsas acusaciones constituyen solo entre el 1\% y el 4\% de las denuncias.

- $\quad$ El abuso sexual infantil es un delito perpetrado en todas las clases y sectores socioeconómicos.

- $\quad 150$ millones de niñas y 73 millones de niños son abusados sexualmente por año en el mundo según UNICEF.

Podemos escucharte y queremos ayudarte.

Te esperamos, acercate ${ }^{14}$.

Durante esta primera etapa no eran muchos en el grupo y sus miembros se contactaron entre sí, individualmente. El caso de Omar, por ese entonces, era bien conocido gracias a la prensa, así fue que distintas personas de distintas partes del país empiezan a comunicarse con él por medio de Facebook. Esta red social será fundamental para el crecimiento del grupo, institucionalización de una imagen y contacto con otras organizaciones que perfilan y comparten características similares. Pero sucedió con los meses. Por ahora, este primer grupo todavía no tenía objetivos muy claros en cuanto a su accionar, dependió mucho del contacto e intercambio con otras organizaciones para llegar, según su misma presentación, a lo que son hoy: Militantes sociales.

\footnotetext{
${ }^{13}$ Este trabajo utiliza para nominar a las personas que intervienen en la investigación las mismas categorías utilizadas por los sujetos para nombrarse.

${ }^{14}$ Transcripción de uno de los primeros panfletos que elabora el grupo y saca a la calle. Por razones antes expuestas es que no damos precisiones del nombre del grupo, ni de sus integrantes.
} 
Ya para el 2014 este grupo, que en principio se pensó como soporte y ayuda de pares, se convirtió en un grupo de militantes que tienen como objetivo visibilizar sus casos y trayectorias de lucha. Es así -e invitados por distintas organizaciones como ser escuelas, centros de salud, hospitales, carreras universitarias- que dieron a conocer los orígenes del grupo, los vericuetos del entramado judicial, las causas y como encaran hoy en día la defensa de los derechos de la infancia ${ }^{15}$. Esta dinámica de visibilización de sus casos es lo que ellos llaman militancia. Va a pasar un tiempo más hasta que se conforme la RED de Visibilización del Abuso Sexual Infantil y con ella la incorporación de nuevas acciones en el espacio público como parte de sus actividades de grupo.

${ }^{15}$ Nos limitamos a transcribir las características que ellos mismos utilizan para nombrarse y describirse. 
Acerca de nuestro colectivo:

Somos un colectivo, autogestionado e independiente, conformado por $* * * * * *$ con la defensa de los derechos de niñxs y adolescentes.

Nuestro objetivo es dar visibilidad al delito del abuso sexual infantil con la finalidad de incidir públicamente en la defensa de la infancia y sus derechos. Y a la vez compartir nuestras propias experiencias con el formato de grupo de ayuda.

Tenemos dos objetivos claros:

1. Visibilización: debido a que nuestro interés es discutir ideológica y políticamente el abuso sexual infantil es fundamental tener un marco conceptual compartido y básico para llevar adelante esa acción. Para esto contamos con instancias formativas tales como charlas, talleres, discusiones, bibliografía.

2. Grupo de pares: se trata de una reunión semanal en donde compartimos nuestras experiencias, fortalezas y esperanzas. Durante estas reuniones cadx unx de nosotrxs habla desde su experiencia y emociones. Intentamos no dar explicaciones teóricas ni damos consejos ni indicaciones. Simplemente es un espacio para compartir en paz, respeto y escucha atenta nuestros testimonios. No es un espacio terapéutico, por lo tanto no está coordinado por especialistas ni profesionales.

Así como el encuentro de ayuda de pares es una instancia horizontal, donde todxs tenemos voz y expresamos libremente nuestro sentir y pensar, el espacio de militancia no lo es y exige acordar en principios básicos. Por lo tanto cualquier aparición pública que no haya sido previamente designada será hecha a título personal.

Finalmente, pero no menos importante, queremos decirte que si estás leyendo esto es porque has tomado la decisión de acercarte a nuestro grupo y eso es muy importante. Te felicitamos por tu decisión y te damos una afectuosa bienvenida ${ }^{16}$.

${ }^{16}$ Última gráfica escrita por el grupo y entregada cada vez que aparecía un nuevo integrante. 
Si bien con algunas variantes, la dinámica de este grupo de ayuda de pares retoma muchas características de los primeros grupos de Alcohólicos Anónimos (AA): “< ..> el anonimato, la participación por acción y convicción propias, el hablar desde la propia experiencia, no interpelar al que habla, la autosuficiencia económica del grupo, el incremento de la responsabilidad y disminución de la culpa y las consignas" (Nieto Zermeño, 2008, p. 37). El modelo es circular, cada una/o habla en el momento en que le toca, sin obligación de hacerlo, la misma queda a voluntad de cada participante. Los vínculos en estos encuentros son horizontales, de pares, pero existe la figura del moderador que, si bien ellos/as no lo denominan así, es el encargado de ordenar los tiempos, intervenir ante el "incumplimiento" de alguna de las normas o cerrar y abrir el encuentro. Por supuesto que este rol lo cumple Omar.

"La modificación de la tribuna a una disposición del trabajo en círculo, fue de carácter central en la propuesta (de AA) debido a que favorece el establecimiento de vínculos simétricos, elemento fundamental en el modelo, pues permite al mismo tiempo generar una dinámica respetuosa y equitativa donde el punto clave es compartir y no enseñar" (Ídem, p. 37). Las reuniones eran una vez por semana dos horas, el cumplimiento del horario de finalización del encuentro es estricto, más de una vez aparecieron los chistes de que tienen una vida que disfrutar y no valía estar toda una tarde encerrados. Los encuentros se llevaban a cabo en un centro cultural de un barrio porteño, con mates y diversas galletitas empezábamos un poco más tarde de las 13 hs. Sin excepciones estas reuniones se concretaban.

La convocatoria era a través de la red social Facebook, convocando a viejos y nuevos participantes a formar parte de esta comunidad de pares. La cantidad de participantes siempre varió -por momentos contabilicé cerca de 11 personas y a veces sólo 5 o 4. Era notable al día siguiente de cada intervención pública como incrementaba el número de participantes, se sumaban a las reuniones personas de distintas lugares y edades. Nada garantizaba su permanencia, de hecho, la gran mayoría asistió a una sola reunión y luego no apareció más. Otros/as ( 3 o 4 personas) permanecieron y hoy son parte de la organización del grupo, planificación de los encuentros y salidas al espacio público. 
Estas salidas al espacio público significan concentrarse como grupo en un punto de la ciudad de Buenos Aires y volantear invitando a quien lo desee a las reuniones de pares. Este encuentro se lleva a cabo una vez al mes en el horario de la reunión. Es así que podrían llegar desde cualquier lugar los próximos integrantes. Esta volanteada dura dos horas aproximadamente y se llevaron a cabo en lugares de gran concentración como ser los bosques de Palermo, Tecnópolis, Caballito, Rosedal, Costanera Sur, entre otros muy concurridos los fines de semana.

Otra de las actividades de visibilización que tienen como grupo es la visita a distintas organizaciones donde los invitan para contar sus experiencias colectivas e individuales. Escuelas del interior de Buenos Aires, hospitales, centros de asistencia, carreras universitarias en el marco de alguna cátedra (psicología, derecho penal, trabajo social), en charlas o simposios, congresos y encuentros académicos. Con muy pocas variantes, siempre es el mismo relato: historias y experiencias personales en relación al abuso sexual, sus peripecias en el entramado judicial, su llegada al grupo y cómo esto repercutió positivamente en ellos. Omar siempre es el encargado de invitar a todos y todas a las próximas reuniones y a ser partícipes del "cambio de paradigma" en la defensa de niños y niñas.

"Somos los adultos y adultas que nos hubiera gustado encontrar cuando éramos niños." Cierran y reparten volantes del grupo.

\section{La red}

"La RED es un grupo de trabajo y militancia integrado por Asociaciones, Organizaciones, Agrupaciones y personas particulares ocupadas en la visibilización, planeamiento social y tratamiento integral de la temática del abuso sexual a niñas, niños y adolescentes. El fin de esta articulación de trabajo es realizar actividades conjuntas que apunten a resolver todos los aspectos relacionados con la prevención, el estado actual de situación social y particular y la resolución de este avasallamiento mundial y masivo de los derechos de niñas, niños y adolescentes" (Estatuto de la RED, Presentación). 
En el 2014 se conforma la RED Nacional de Visibilización del Abuso Sexual. Todas las organizaciones o grupos militantes con los que tuvimos contacto en el trabajo de campo (charlas y encuentros) forman parte de esta Red que las nuclea y traza acciones en conjunto. Los grupos fundadores de esta Red fueron grupos de ayuda a víctimas de abuso sexual que a puro pulmón tuvieron la impaciencia por conocerse e intercambiar material, hubo una necesidad de dialogar con otras partes del país y así, de esta necesidad, se creó la Red de organizaciones.

Con las redes sociales de gran aliada, las organizaciones y particulares se empiezan a agrupar e intercambiar información con el fin de establecer una puesta en común de lo que ellos/as denominan "la lucha en contra del avasallamiento masivo de los derechos de niñas, niños y adolescentes". La ONG con la que trabajamos para esta tesis forma parte de las organizaciones de la red. Esta articulación cobra relevancia y fuerza a fines del año pasado y principios de este (2015), cuando se hace presente en el espacio público con una serie de intervenciones en tribunales en claro acompañamiento a las víctimas y familiares de delitos sexuales.

Actualmente cuenta con 265 miembros en todo el país, los cuales tuvieron que atravesar tres instancias antes de que sea "aprobada" su incorporación, "primero el envío del estatuto para que lo revisen y acepten las condiciones propuestas de trabajo, luego se les enviará una encuesta (dónde completarán sus datos personales, agrupación/organización y motivo de solicitud de entrada), y, por último, se hará una entrevista con varixs integrantes de La Red, sea en persona o vía skype, para conocerlxs personalmente" (Estatuto. Reglamento). Si bien en un inicio esto no estuvo muy claro, quienes participamos desde el principio de la conformación de esta Red, fuimos parte de los largos e intensos debates que dieron origen a esta organización. Los debates fueron a través de la cuenta en Facebook de la red, asambleas en el Hotel Bauen (CABA) con la modalidad de skipe para quienes estuvieran lejos y puesta en común de los escritos a través de las redes. Durante la etapa fundacional de esta Red participé como parte del equipo de prensa: emisión y confección de comunicados, noticias y notas fueron mis deberes. 


\section{Creencias que circulan}

Para construir su propio relato, estas organizaciones dialogan... o contestan ( $\mathrm{si}$ he de ajustar la palabra) a ciertas creencias que circulan en la esfera social y judicial sobre los delitos sexuales que tienen que ver con el abuso sexual hacia niños y niñas. Si bien este apartado es sólo descriptivo, hemos de adelantar que parte de su discurso está construido en base a respuestas a falsas creencias o del sentido común en torno al abuso sexual.

El SAP, la supuesta "anormalidad" de los/as abusadores/as, el delito asociado siempre a sectores pobres, los niños/as mienten, los abusadores son siempre varones, silenciar para olvidar... son algunas creencias (las organizaciones lo denominan "mitos") que circulan en el imaginario social y que muchas lo toman como base para construir su propio relato.

Los perversos no están en los cuentos. Los abusos sexuales se dan a nivel intrafamiliar o por un conocido de la víctima.

Los monstruos no están en los cuentos.

Es tu hijx, tu nietx, tu hermanx, tu vecinx. Somos todxs. Basta de abuso a niñxs.

Mantener el silencio es ser cómplice. ${ }^{17}$

EI SAP (Síndrome de Alienación Parental)

"El síndrome de alienación parental (SAP) es un trastorno infantil que surge casi exclusivamente en el contexto de disputas por la custodia de los niños. Su manifestación primaria es la campaña de denigración del niño contra un padre, una campaña que no tiene justificación. Ello resulta de la combinación de una programación (lavado de cerebro) de adoctrinamiento parental y de las propias contribuciones del niño para el vilipendio del padre objetivo. Cuando un “maltrato/abuso sexual” está presente, la animosidad puede estar justificada y

\footnotetext{
${ }^{17}$ Son algunas de las frases que circularon en panfletos y pancartas confeccionados por la RED y distribuidos el 19 de noviembre del 2014 con motivo del Día Mundial de prevención del abuso contra niños y niñas. Concentración en el Obelisco. 18 hs.
} 
así la explicación del síndrome de alienación parental para la hostilidad del niño no es aplicable." (Gardner en Escudero, Aguilar, Cruz, 2008, pp. 285-286) ${ }^{18}$

A pesar de la anterior explicación, este argumento es utilizado y escuchado en reiteradas oportunidades por abogados defensores en juicios por custodia o de revinculación parental. La revinculación parental es la orden de un juez de restablecer los vínculo familiares rotos con su progenitor/a separado/a de ese niño/ $\mathrm{a}^{19}$. En este contexto, las revinculaciones forzadas son casi un comodín: son los Juzgados de Familia quienes obligan el restablecimiento de los vínculos del niño o niña con el/la progenitor/a. En este contexto, vínculos rotos por sospechas de abuso traducida en denuncia civil y/o penal.

No fueron pocos los casos que, en contexto de disputa por tenencia y con una denuncia penal de por medio por abuso sexual, la defensa utilizara y citara a este autor y a este supuesto "síndrome" para dar cuenta del "lavado de cerebro" del que fue víctima el niño/a para que hablara en contra (pero no exclusivamente) del padre. Las organizaciones sociales de la RED suelen estar muy atentas a estos argumentos y tienen registro de quienes son los/as abogados/as que hablan en estos términos y quiénes son los/as jueces/zas que dan lugar.

Este supuesto síndrome fue desmentido por varias organizaciones referentes en el tema, entre ellas dos de las más importantes a nivel internacional (Organización Mundial de la Salud y la Asociación Americana de Psicología) por considerarla carente de pruebas y estudios.

\footnotetext{
18 GARDNER, R. A., «Legal and Psychotherapeutic Approaches to the Three Types of Parental Alienation Syndrome Families. When Psychiatry and the Law Join Forces», Court Review, 1991, 28, 1, pp. 14-21.

GARDNER, R., A., «Parental Alienation Syndrome vs. Parental Alienation: which Diagnosis Should Evaluators Use in Child-custody Disputes?» The American Journal of Family Therapy, 2002, pp. 93-115. 19 "Los procesos de revinculación suelen proponerse en presencia de alguna de estas situaciones: a. Luego de una separación de la pareja parental subsecuente a una denuncia por abuso sexual, en el contexto de un diagnóstico no concluyente o que descarta la posibilidad de que el abuso haya ocurrido. b. Luego de una separación subsecuente a una denuncia por abuso sexual, en el contexto de un diagnóstico plausible o validatorio; en los casos en que hay, además, una denuncia penal, estos procesos pueden instalarse durante su sustanciación y antes de que se dicte sentencia; incluso- en el peor de los casos- antes de que se inicie cualquier tipo de instrucción en lo penal." (Baita y Visir en Volnovich, 2006, p. 143)
} 
"Este fracaso de la teoría SAP como pretensión cientifica se debió a la incapacidad del Dr. Gardner para diagnosticar la enfermedad o trastorno psíquico del "síndrome" por él descrito; pues era -y es- obvio que sin una previa concatenación etiológica desencadenante del morbo originante no puede constituirse sintomatología alguna significativa del mal. Esta pretensión de Gardner de conjuntar bajo un signo psicológico predeterminado, actos y actitudes producidos por la parte litigante en el proceso judicial sin la previa definición del trastorno psicológico que los produjese, entrañaba en sus propios fundamentos médicos un error cientifico insalvable, que es lo que impidió la aceptación de su hipotético síndrome por los Organismos oficiales de la Medicina internacional." (AAVV, 2010, p. 4)

Es decir, Gardner fue incapaz de demostrar que este "síndrome" es preexistente al proceso judicial por la custodia de ese niño/a. No existió una definición previa del trastorno.

“La definición del Síndrome de Alienación Parental, también conocido por su acrónimo SAP, fue publicada por primera vez por Richard Gardner. La difusión y defensa del SAP fue la principal actividad intelectual de este autor. Su principal actividad pública fue como psiquiatra contratado en litigios por la custodia de los hijos. Gardner sigue siendo, aún después de su muerte en 2003, el principal referente teórico del término." (Escudero, Aguilar, Cruz, 2008, p. 285)

La RED en su Estatuto (en nombre de todas las organizaciones que la componen) se posiciona en contra de "este falso síndrome" como lo denominan. Circular y hablar con militantes de esta RED permite detectar esta valoración común con respecto al SAP, todas/os tenían conocimiento de qué es, por experiencia propia (lo habían utilizado como argumento en su contra) o por experiencia de compañeras (la mayoría de los juicios por custodia y revinculación eran de mujeres). El uso por parte de abogados defensores y fiscales de este falso síndrome se convirtió en enemigo de todas las agrupaciones que componen la Red, se hizo necesaria la lectura de materiales que ayuden a pelear contra todo un sistema que no facilita para nada la resolución favorable de estos crímenes. Así circuló en la Red artículos científicos, fallos, información de 
abogados/as especialistas, las organizaciones se armaron de información y pudieron construir un relato más o menos unificado sobre ciertos temas que ayuden en las causas y presten visibilidad a un tema oscuro y con tantas aristas. Esta Red la componen especialistas de muchas disciplinas que desde sus saberes disciplinares pusieron a disposición material y trabajo profesional para ayudar.

\section{No son monstruos}

El calificativo "perverso" aparece todo el tiempo, en todos lados en este trabajo de campo e indagación. Si bien uno de los relatos de estos grupos militantes es no pensar a los/as agresores/as como "monstruos" muy difíciles de encontrar, esta característica aparece todo el tiempo en sus relatos (como así, en las terapeutas, en las militantes, en las víctimas).

La finalidad de estas líneas no es analizar este punto aún pero veremos más adelante como se construye esta idea de "monstruosidad" a pesar de los intentos por alejar esta idea del imaginario social. El mensaje es que puede ser cualquiera, tu vecino/a, tu primo/a, tu hermano/a...una persona "común y corriente" sin marcas visibles o características que "hagan sospechar". A pesar de que las terapeutas sostienen esto, veremos cómo desde la disciplina aparece muy fuerte esta idea de lo completamente otro, lo abyecto, para pensar a abusadores/as sexuales todo el tiempo.

La categoría de perverso/a va a estar muy ligada a esta construcción del monstruo no tanto por sus características físicas o personales sino por lo que significan sus acciones frente a determinadas víctimas. El o la abusadora de niños y niñas no va a poder ser concebido dentro de las categorías lingüísticas tradicionales, tanto es así que ante lo innombrable, ante la maldad más pura y mitológica del abusador/a la categoría de "monstruo" ligada a la idea de perversidad va a venir a salvar esa ausencia calificativa. Aún cuando insistan desde distintos frentes, distintas voces e involucrados estas apreciaciones siguen apareciendo muy fuerte en sus discursos. Lo abyecto (Kristeva, 1989), lo completamente otro va a encontrar su nominación dentro de estos parámetros a partir de categorías que provienen de la psicología y de la mitología: el monstruo/el-la perversa. 
"No es por lo tanto la ausencia de limpieza o de salud lo que vuelve abyecto, sino aquello que perturba una identidad, un sistema, un orden. Aquello que no respeta los límites, los lugares, las reglas, la complicidad, lo ambiguo, lo mixto. El traidor, el mentiroso, el criminal con la conciencia limpia, el violador desvergonzado, el asesino que pretende salvar...” (Kristeva, p. 11, 1989)

Es todo aquello que irrumpe, quiebra la norma, la regla o la ley, deja al descubierto la fragilidad del sistema y lo expone. "La abyección es inmoral, tenebrosa, amiga de rodeos, turbia: un terror que disimula, un odio que sonríe, una pasión por un cuerpo cuando lo comercia en lugar de abrazarlo, un deudor que estafa, un amigo que nos clava un puñal por la espalda" (Ídem). No es el anormal sino aquello que alguna vez integró un nosotros y en algún momento pasó la frontera de la cultura para convertirse en un (los) otros.

\begin{tabular}{|c|}
\hline LOS MONSTRUOS \\
NO están \\
EN LOS CUENTOS. \\
LOS ABUSOS SEXUALES \\
se dan a \\
nivel intrafamiliar \\
o por un conocido \\
de la \\
VÍ́CTIMA \\
19 DE NOVIEMBRE \\
Día Mundial de prevención del \\
abuso contra niños y niñas. \\
18 hs. Obelisco
\end{tabular}

\footnotetext{
${ }^{20}$ Panfleto diseñado por La Red para el 19 de noviembre del 2014 distribuido en la intervención realizada por las organizaciones que componen la Red en el Obelisco, Ciudad de Buenos Aires con motivo del Día mundial de prevención del abuso contra niñas y niños.
} 
Ese día distintas organizaciones realizaron una intervención en el Obelisco no solo artística sino de pedido de justicia por todos los casos que aún no fueron resueltos. El ambiente que rodea a estas luchas es relativamente pequeño así que la alusión a determinados casos son ya conocidos, como así los distintos profesionales que desde distintas disciplinas trabajan de cerca con estas organizaciones. En cada reunión, intervención o marcha nos conocíamos todos y todas, esta Red funcionaba realmente como tal: los contactos, la información y el acompañamiento circuló por cada organización que la compuso.

Como anecdótico, ese mismo día circuló un panfleto que llamó mi atención, en ese momento no entendí bien por qué pero lo guardé entre mis notas de campo. Con el correr del campo y la reiteración de la misma palabra aparentemente sin discriminar contextos se me disparó parte del capítulo 3.

El panfleto en cuestión es el mismo que el anterior sólo que reemplaza la palabra monstruo por perverso.

\section{Los niños/as (no) mienten}

"No creerles a los niños y niñas es acumular goces en el océano de perversiones con las que el abusador se satisface" (Eva Giberti).

Por tratarse de niños/as pequeños/as son frecuentes las expresiones fragmentadas e incongruentes, situación en que es preciso contar con terapeutas entrenadas en interpretar los indicadores de abuso y violencia. Las terapeutas que trabajan con niños y niñas en situación de abuso sexual y llegan a la instancia de juicio como profesional pericial o como testigo afirman que es muy recurrente que no crean en la palabra de la víctima por tener un relato no solo inconsistente sino con características "fantasiosas", como lo califican ellos. En la ONG entrenan a sus terapeutas para que puedan hacer frente a estas acusaciones con insumos técnicos de su disciplina: la explicación de los criterios de validación de sospechas, los resultados de los test, las características cognitivas del niño y niña que ha atravesado por esa situación y las formas que utilizan en la ONG para llegar a ese relato. Por supuesto que, frente a un relato articulado, coherente, con sentido temporal y espacial del/a acusado/a, al niño o niña le queda poco margen por competir en un juicio pensado por adultos. 
“La función de los profesionales que realizan la evaluación de las sospechas no es diagnosticar ni certificar si los entrevistados dicen la verdad o si mienten. Su tarea consiste, ni más ni menos, en recoger información de un niño o adolescente, de la manera menos coercitiva posible, y determinar si lo que ha dicho puede ser tenido en cuenta con miras a la puesta en marcha de algún tipo de intervención que podría eventualmente complementarse con una investigación judicial." (Intebi, 2011, p. 179)

Quizás esta confusión conceptual de lo que significa hacer una validación de sospechas de abuso sexual es lo que obstaculiza la resolución favorable para el niño, niña o adolescente en conflicto. Suelen interpelar a la profesional de la salud en términos de, ¿miente o no miente el niño/a? cuando la profesional está allí para interpretar si la información recabada en EP es motivo o no para la intervención de la justicia y su pronta resolución.

Muchas veces escuché decir, de parte de las profesionales, que una o un psicólogo que no está preparado para detectar casos de abuso sexual le es imposible ver estas pistas que el niño o niña arroja cuando está en peligro. Motivo de amplio debate al interior de la disciplina (psicología) todavía constituye una deuda no saldada unificar criterios de credibilidad ante el relato de un niño o niña. Tanto es así que constituyen pocos los y las profesionales capacitados en la problemática de abuso y aún más pocos son los que deciden confiar en esos indicadores por más "leves" que sean.

"Resulta cada vez más complejo y frecuente transitar por esa zona gris establecida por la sospecha fundada de la existencia del abuso sexual en la infancia y su validación. En especial, niños pequeños, cuyos relatos son incongruentes o excesivamente imaginarios, o simplemente no hablan, y que revelan en juegos y dibujos haber sido objeto de abuso sexuales, para luego negar juegos y palabras, junto con progenitores altamente comprometidos psicopatológicamente, construyen esta zona gris en donde varios autores han intentado incursionar para visibilizar y validar el abuso deshonesto, en especial, el incesto, desde un punto de vista psicológico y psiquiátrico." (Volnovich, 2006, p. 117) 
Son estos profesionales los que sostienen que ningún niño o niña fabula o miente sobre lo que desconoce.

"La falta de habilidades de un niño o adolescente para describir los abusos sexuales no significa que estos no hayan ocurrido. Significa que no han podido confirmarse, algo bien diferente de la posibilidad de que no hayan sucedido. Las investigaciones con adultos que sufrieron abusos sexuales en la infancia indican que muchas víctimas no lo cuentan nunca." (Intebi, 2011, p. 181)

Así, numerosas investigadoras han propuesto diversos criterios de validación del testimonio del niño, niña o adolescente (Susan Sgroi, Kathleen Coulborn, Faller, Benedek y Schetky, Corwin, Gardner, Heiman, Raskin y Esplin, Wehrspann y cols.).

\section{Cierre}

Como vimos -y en adelanto a próximos capítulos- el relato de la experiencia del abuso sexual, dependiendo de la situación comunicativa en la que es enunciada y de sus interlocutores, adquiere características discursivas específicas: de forma $\mathrm{y}$ contenido. Estas líneas buscaron describir esas escenas comunicativas concretas y sus posibles interlocutores tanto al interior de cada situación como con otras esferas que intervienen en la trama comunicativa. Buscamos reconstruir las voces y las huellas del complejo entramado que constituyen sus relatos, no son discursos individuales sino parte de un gran diálogo y en ese gran dialogo es que buscamos identificarlos.

El conocimiento profundo de los contextos y situaciones comunicativas son fundamentales para pensar la metodología de investigación, su abordaje esprecisamente- a través del conocimiento de los tiempos de rutina y procedimiento de ambas. El trabajo con organizaciones que marcan sus tiempos en función a la cantidad de sesiones para una EP o con un grupo que organiza sus reuniones en función a la capacidad o no de narrar/contar lo que vivieron tira a pensar formas de intervención armónicas con su entorno. Los protocolos y reglamentos de intervención y regulación de estas escenas no siempre se empalman con los de una investigación social, pero ¿qué sucedería si coincidieran? El desafío de esta investigación es la búsqueda de esos 
empalmes y vericuetos para acceder a los datos y -posteriormente- el análisis de esos datos con las herramientas teóricas que disponemos. Como veremos, los relatos de experiencia traumática de este tipo son codificados desde distintos lugares e interpretaciones, cada escena comunicativa imprime sus huellas y su performance a la hora de codificar eso inaprensible que es el dolor, el trauma. Serán los objetivos de los próximos capítulos señalar tiempo e intensidad en el trabajo de campo, fundamental para pensar las herramientas de "recolección de datos".

En el próximo capítulo -marco teórico y metodológico- nos explayamos sobre las características que adopta el trabajo científico cuando interviene en dinámicas institucionales tan particulares y los obstáculos que deberá sortear para acceder al mismo. No son espacios cerrados pero sí íntimos, que de tan íntimos dificultan el acceso y su reflexión. Son diálogos no solo con estas organizaciones sino con una comunidad científica que ya ha reflexionado sobre estas problemáticas y que pone el foco en el accionar ético, político y reflexivo de los científicos y científicas. 
- ¿Me podrías contar exactamente lo que le has contado a Grethe?

- Por favor, cuéntale lo que me dijiste del corazón.

- Yo no he dicho nada.

- ¿Se lo está inventado todo Grethe?, ¿o te lo has inventado todo tu?

(Niega con la cabeza) “no”

- Entonces inténtalo... y cuéntamelo a mi también.

La niña se queda callada.

- Contarlo está bien Klara.

- ¿Es verdad que has dicho que has visto el pito de Lucas?

Klara niega con la cabeza.

- Intenta contarme lo que hizo Lucas. A ver si puedes contarme un poco de ello, Klara.

- Quiero salir a jugar.

- $\quad$ Sólo tienes que contestar, Klara.

- $\quad$ No tengas miedo, Ole no te hará daño. Sólo quiere que nos cuentes lo que ha pasado.

- ¿ ¿Fue aquí en la guardería donde te enseñó el pito? ¿Fue aqui Klara? ¿Klara?

Klara asiente con la cabeza.

- Estas asintiendo. ¿Entonces fue aquí en la guardería?

Vuelve a asentir Klara.

- $\quad$ Dime que más sucedió después. Grethe me ha contado que tú le has contado que estaba en punta. ¿Estaba su pito en punta?

- $\quad$ Creo que sí. No me acuerdo.

- ¿Entonces te ha enseñado su pito?

Klara asiente con la cabeza

- Klara ¿te sientes incómoda al hablar de Lucas?

Klara asiente.

- ¿Es porque no te gusta lo que te hizo?

Vuelve a asentir.

- Klara, estas respondiendo mis preguntas muy bien... ¿Qué hizo después de enseñarte el pito?

- No lo sé.

- ¿ ¿Te tocó? ¿Te acuerdas? ¿Salió algo blanco de ahi? ${ }^{21}$

\footnotetext{
${ }^{21}$ De la película "The Hunt" (La Cacería) de 2012, del mismo director de "Die Feste". Extracto del diálogo entre Klara, la directora del jardín y el trabajador social que va a interrogar a la niña sobre sus comentarios, a la directora, sobre su profesor Lucas.
} 


\section{Capítulo 2}

\section{Encuadre Teórico - Metodológico}

Cartografías para escuchar lo indecible

\section{Introducción}

Este capítulo es el despliegue del mapa teórico-metodológico de la tesis, separados sólo a los fines descriptivos buscamos trazar las principales coordenadas para abordar este problema. En un primer momento las reflexiones en torno a las tradiciones y estudios a los que acudimos para pensar aristas del problema -los Estudios Culturales en Comunicación y las Teorías Poscoloniales de Género- vienen a abonar el terreno con preguntas que no son nuevas pero planteadas en contextos específicos como éstos arrojan algo de luz a esta maraña.

Ya en una segunda parte presentamos los conceptos troncales de la tesis, las Categorías Analíticas que desplegaremos: Experiencia y Narrativas. Este despliegue no sólo busca la enunciación de sus categorías sino reflejar el desafío de trabajar con distintas disciplinas, todas con aportes y miradas distintas a la confección del problema y del análisis y aún así fundamentales para el estudio comunicacional del problema del contar la experiencia traumática. 
Si bien analizamos relatos bien específicos enunciados en dos situaciones comunicativas concretas nos preguntamos: ¿que implica hacer relatos científicos de relatos de experiencia traumática? Vamos a ver cómo la experiencia sufre varias transformaciones, dependiendo de cada situación comunicativa y nuestras categorías nos ayudarán a ver y comprender estas transformaciones, como así su última codificación en términos científicos para la presente tesis.

En la segunda parte trabajaremos con la metodología de la tesis. Uno de los pilares de este trabajo, fue pensada exclusivamente a partir de nuestras preguntas de investigación y las características de nuestro campo: ¿Cómo interpelamos desde la investigación social? ¿Cómo se juega la autoridad etnográfica en estas tramas? Y pensando(nos) como escuchas e intérpretes de recuerdos dolorosos traemos a ScheperHughes (1997) para preguntar(nos): ¿se puede ser antropóloga y companheira al mismo tiempo?

"Con muy pocas excepciones, los antropólogos (o etnógrafos de cualquier disciplina podríamos agregar) en general no han descripto las muchas razones por las que una comunidad se da a conocer a un extraño. Tal vez esta reserva se debe a la creencia de muchos antropólogos (etnógrafos) de que la información que reciben se debe a sus cualidades personales, algo así como un don especial para establecer relaciones con extraños (...) una simpatía evidente hacia su modo de ser u otras señales de un atractivo personal irresistible [...]” (Sudhir Kakar 1996, p. 91 citado en Auyero, 2004)

Este despliegue trae todos los miedos que surgen (me surgieron) una vez empezado el trabajo de campo. Allí ante el primer testimonio de violencia contra una niña de 11 años es que me pregunte por la autoridad etnográfica de la que nos hablaba Clifford (1998) poniendo en crisis la mirada del investigador en campo. A medida que fueron pasando los meses otras preguntas (y miedos) atropellaban mis tímidos análisis, porque el problema mayor no fue la escucha detrás del espejo falso de la cámara gesell, los verdaderos problemas de ética profesional y responsabilidad etnográfica comenzaron en la interacción con víctimas que relataban sus historias en vivo en un grupo de pares. Fue allí mismo donde los interrogantes pilares del análisis metodológico de esta investigación surgieron. 
En la etapa de reflexión metodológica fue fundamental dialogar con disciplinas como la psicología y el trabajo social, necesitaba de muchas de sus herramientas para manejar testimonios, emociones personales $\mathrm{y}$, sobre todo, mi relación con los adultos que pertenecían al grupo de pares. Nunca necesité tanto de la asesoría de otros profesionales como en estas instancias de trabajo.

Tomar en serio a la violencia significa, priorizar ante todo el respeto por el otro, la escucha atenta, el diálogo (porque es el otro quién está confiando en nosotros al compartir su vida), tener siempre en cuenta el plano emocional, "erótico" (Figari, 2001) de la situación de intercambio, del "cuerpo a cuerpo", de comunión, de compartir: el espacio de comunicación. Este conjunto de decisiones no solo metodológicas sino éticas y políticas es la actividad principal del investigador, "para eso producimos saber, para hacer política" (Harding, 2009). Debemos presentarnos no "como la voz invisible y anónima de la autoridad", sino como la de un individuo real, histórico, con deseos e intereses particulares y específicos (Ídem, p. 7).

Para cerrar e iniciar, éstos son temas que nos convocan y nos movilizan desde lo personal y lo académico: son las ansias de una ciencia que no excluya, que no borre las narrativas del investigador ni las experiencias de sujetos sexuados que se ubican (los ubican) fuera de "la norma" (ser varón/mujer, blanco/a, burgués/a, heterosexual y cristiano/a). De Sousa Santos se preguntaba “¿por qué yo me involucro en la lucha por los derechos humanos?” (...) "porque veo que hay violaciones a los derechos humanos, porque mi estómago siente algo que yo no puedo racionalizar. Entonces hay que crear este conocimiento, esta relación compleja entre razón e ilusión.” (2009, p. 154)

\section{Referencias de lectura y escritura:}

El sujeto enunciador de estas tramas navega entre la primera persona del singular y primera del plural, lejos de entorpecer las lecturas, buscamos dar cuenta de las distintas instancias de este trabajo: reflexiones personales y grupales. Si bien todo el trabajo fue pensado y escrito a partir de muchos aportes, hay momentos (huellas) muy personales de la reflexión que quise estuvieran presentes en estas líneas. Además rescatar las narrativas personales, muchas veces ausentes en narrativas científicas. 


\section{Primera Parte}

Este capítulo busca ser un mapa reflexivo para llegar a las categorías de Experiencia y Narración, conceptos troncales en el análisis de esta tesis. Un mapa no para seguirlo al pie de la letra sino más bien una bitácora de viaje que dé cuenta de las dificultades del recorrido, de los obstáculos, de los remansos y de los remolinos que el agua siempre trae. Bien flexible, bien maleable, cambiante, útil para identificar cruces, cortes y continuidades. Un mapa que nos permitirá llegar con herramientas reflexivas más sólidas (o porosas por su maleabilidad) para pensar el campo.

\section{Cruces teóricos}

Este primer apartado desarrolla el encuadre teórico y fue separado de lo metodológico sólo a los fines organizativos de la tesis. En esta primera parte haremos la presentación y justificación de los cruces teóricos: los Estudios Culturales en comunicación, por un lado, aportan una mirada crítica y deconstructiva de la noción misma de identidad como "lugar sustantivo de autenticación" o como entidad preconstituida distintivamente que ubicaría casi automáticamente en el mapa jerárquico a los/as sujetos. Este gran paraguas teórico nos direcciona hacia reflexiones que tienen que ver con el campo de la comunicación, en esta práctica del deconstruir los lugares y espacios de poder, es en este desplazamiento o complejización de la reflexión donde nos ubicamos. Todas las reflexiones que tienen que ver con incorporar los propios lugares de enunciación a los materiales de estudio y el cruce con el estudio de narrativas son los aportes que contribuyen a pensar el problema. De hecho, los procesos comunicativos no podrían ser pensados por fuera de los contextos que los cobijan, si seguimos en esta línea de estudio, todo proceso de comunicación significa y tiene sentido en la medida que se lo piense y entienda en cada situación. No es posible identificar prácticas o procesos que no signifiquen, todo lo que realizamos comunica y si comunica posee valoración. La valoración va a depender de normativas, reglas y convenciones locales que no solo regulan y encauzan las prácticas comunicativas en determinados contextos, sino que determinan el sentido que adquieren en ese momento histórico. Entender el funcionamiento de estas lógicas que regulan y encauzan las prácticas es una puerta de acceso a la comprensión de estos procesos que se muestran, en principio, oscuros y truncos. 
Por otro lado, los Estudios de Género y Sexualidades con su crítica a toda categoría normativa y su capacidad de deconstruir los lugares de enunciación de las mismas reflexiones nos acercan el concepto de Experiencia, entendida no sólo como material sensible de ser incorporado al análisis, sino como lugar para habitar el saber y como posibilidad de comprender la estructura social.

Lo que nos interesa de ambas perspectivas es la desconstrucción de nociones como identidad y experiencia y su empalme, o ubicación en mapas superpuestos, para dar cuenta de las condiciones de enunciación/ producción de estos relatos. Por un lado, en contexto de evaluación psicodiagnóstica en Cámara Gesell con niños, niñas y jóvenes que sufrieron abuso sexual intrafamiliar y reuniones de ayuda de pares de adultos y adultas "sobrevivientes" de abusos sexuales y, por el otro, los relatos en cuestión. Ambas perspectivas cuestionan y ponen en tensión los lugares de enunciación de los relatos convirtiéndolos en experiencias narrativas, lugares dónde el sujeto termina de vivir la experiencia corporal (a partir de la experiencia narrativa). De allí la centralidad epistemológica de la experiencia que habilita las preguntas por los lugares de enunciación del mismo investigador y por las condiciones de producción de estos análisis: ¿Es el estatuto sensible del investigador material pertinente para el análisis?

Entonces, no solo nos interesa la experiencia narrativa del abuso sexual de los/as sujetos/as en éstas dos situaciones específicas de dos grupos distintos sino que el abordaje metodológico específico que construimos a partir de estas perspectivas teóricas con la tensión puesta en la experiencia analítica del investigador en relación al campo. Para estos estudios la identidad pasa a ser arena de lucha por los sentidos pero estas luchas no se dan de manera aislada, sino ancladas, ubicadas, trazando fronteras, estableciendo límites porosos (o no). Ambas perspectivas nos alertan, por un lado, la necesidad de contextualizar los análisis y en esta contextualización de las reflexiones, la experiencia como parte de los materiales de análisis, como única "escapatoria” a las trampas del subjetivismo (Haraway); y por el otro, en este cruce entre condiciones de existencia y la producción del relato. El desafío es describir y analizar todo lo que sucede con el relato dentro de estas situaciones comunicativas y localizar las continuidades, quiebres, cambios o no que sugieren los relatos de experiencia traumática. 
Ya en una segunda parte (Categorías Analíticas) y con estos dos cruces teóricos como arena para la reflexión, tomaremos para el análisis los conceptos de Experienciaque deviene de los estudios poscoloniales y de género/sexualidad (Mohanty, Scott, Haraway) -entendida como centralidad epistemológica y como espacio necesario de habitar para la construcción del conocimiento. Y el concepto de Narrativas, con cierta tradición en los estudios en Comunicación, para este trabajo será entendido como materialidad simbólica, como aquello que da forma al mundo real y es una matriz para pensar y formular los relatos (Bruner, 2003/2013) como una de las formas primordiales de mediación y modelación de la experiencia que opera en la elaboración de los formatos (García, 2004). Estos conceptos son pensados en tensión con estas dos perspectivas que facilitarán el mapa analítico (o de preguntas) para pensar: desde los EC la pregunta por el otro y esta idea de cultura como la arena para localizar las disputas por el sentido (Martín Barbero), en tensión con los planteos desde los estudios de género y sexualidad por las condiciones de enunciación/producción del conocimiento, la utilización o no del plano experiencial para la producción del saber y la ubicación jerárquica en el esquema de decisiones. Por otro lado veremos, cómo los EC se montan sobre esta misma idea de construcción del conocimiento a partir del lugar de enunciación, porque la conciencia real de los lugares dentro de la escala jerárquica social contribuye en gran medida a la precisión de la mirada crítica. Así de politizado fue el inicio de los EC.

\section{Estudios Culturales en Comunicación}

Los Estudios Culturales en comunicación, entienden a la identidad como "lugar sustantivo de autenticación" o como entidad pre-constituida distintivamente que ubicaría casi automáticamente en el mapa jerárquico a los/as sujetos. Los EC (Estudios Culturales), lo que vienen a desarticular es esta definición de identidad como estable, autosuficiente, que da cuenta de una sociedad pre-establecida en casilleros particulares para cada grupo o sector social, como lugares formales de reconocimiento. Otro aporte que realizan estos estudios -y del que nos valemos para empezar a estirar de nuestro ovillo analítico para pensar preguntas- es, la articulación entre las distinciones culturales (de edad, etnia, sexo/genérica) con las condiciones de vida como ser la desigualdad social, la pobreza, la exclusión. Esta articulación y análisis nos permitirá ver qué condiciones de acceso (o no) poseen estos sectores con respecto a la toma de decisiones 
sobre sus condiciones de existencia (Elizalde, 2008). Con estos cruces, entendemos a las identidades como espacios de lucha que cruzan las experiencias de los sujetos con sus condiciones no solo de existencia material sino de percepción de esa experiencia a través del lenguaje (Rodríguez, 2010).

"Tanto los planteos de Gramsci ligadas a la hegemonía como a las prácticas culturales influyeron notablemente en estudiosos inscriptos en la llamada nueva izquierda europea. Una cantidad de fenómenos incentivaban la necesidad de nuevos planteos en el marco del pensamiento socialista” (Entel, 1993, p. 145). ¿Cómo y por qué estudiar a los sectores protagonistas de la revolución? ¿Pueden las estructuras macro explicar los comportamientos cotidianos? ¿Cómo estudiar la cultura de la massmediación?

Así -y al término de la Segunda Guerra Mundial en la década del '50, en la Inglaterra industrial- la institucionalidad de estos nuevos debates y preguntas fue en 1964 en la Universidad de Birmingham con el Centre for Contemporany Cultural Studies (CCCS). Fueron los intelectuales de este nuevo paradigma quienes discutieron sobre/desde el término "cultura" con una mirada amplia, antropológica, desplazada del vínculo cultura- nación a un enfoque de la cultura de los grupos sociales. Si antes las manifestaciones o prácticas comunicativas referidas sólo a las elites (la pintura o determinados estilos de música como el clásico, por ejemplo) eran las únicas merecedoras de ser consideradas como cultura, con este movimiento o desplazamiento de la reflexión, toda práctica comunicativa o de intercambio de sentido es considerado como cultura. Este desplazamiento reflexivo -según Mattelart y Neveu (2004)- se debe a tres factores: en primer lugar a la aparición de una nueva camada de estudiantes universitarios que gracias a la democratización de la universidad se convirtieron en primera generación en acceder a estudios superiores. Este sector estudiantil trae consigo todas las experiencias que el sector popular, obrero y trabajador carga consigo, es un bagaje de experiencias nuevas que jamás ingresó al recinto universitario y en ese momento significó de un valor epistemológico más que valioso. Nuevos relatos, nuevas miradas y perspectivas. Este fenómeno acarreó el segundo y es el ingreso de esta camada de jóvenes como profesores e investigadores de la universidad y con ello la puesta en crisis de las jerarquías académicas y materias que trabajaron históricamente en el análisis de lo que hasta ese momento se consideró como producción cultural. ¿Por qué las prácticas juveniles no podían ser parte de los materiales de estudio? Lo popular 
aparece con fuerza y se instala como categoría analítica deconstruyendo y posicionando nuevas experiencias merecedoras de ser analizadas en contexto. Esta revuelta reflexiva encontró eco en otros países, convirtiendo a Birmingham en foco de importación conceptual y reflexiva, este fue el tercer factor que ayudó a consolidar como corriente de estudios a los EC. De pronto las prácticas comunicativas de obreros, jóvenes o sectores populares pasaron de un altillo o sótano al ojo de estos intelectuales que los consideraban igualmente merecedores de pensarlos.

El anclaje fue político y el eje pensar las prácticas de distintos colectivos considerados como el "under" de la sociedad (y en especial a los sectores populares) como productores de prácticas culturales: ¿cómo dan respuesta y rechazo al orden social? O, a la inversa, como forma de adhesión a esas relaciones de poder (Mattelart y Neveu 2003/2011). Todos sus miembros compartían la misma fascinación por aquellos temas y problemas que la academia tradicional consideraba como "un pintoresco vanguardismo", aquellos que no valía la pena investigar, esos temas guardados en algún cajón olvidado, temas que no estaban dentro de la agenda y los intereses del establishment universitario de aquel entonces. Esta perspectiva, que dialoga y critica fuertemente al marxismo ortodoxo vía una relectura de Antonio Gramsci, considera a la cultura como materialidad. Como una compleja, inacabada trama de prácticas tanto materiales como simbólicas que, articuladas a condiciones sociales y políticas de producción, presentan lucha por la producción de sentidos. Para esta concepción de la cultura, la misma no se impone total, neutra o pasivamente sino que es una trama compleja de sentidos que producen efectos, acciones, respuestas. En este sentido, el interés de los estudios culturales son las prácticas cotidianas de determinados sectores en el contexto de vida cotidiana, ¿qué sentido le dan a estas prácticas? Esas prácticas pequeñas, chicas, cotidianas significan y tienen sentido en ese contexto, ese anclaje no solo temporal sino espacial dentro de la escala social tiene gran relevancia en la búsqueda de sus significados. ¿Qué sentidos le atribuyen a sus prácticas? Y la mirada puesta en los contextos de enunciación de estas prácticas y su relación dentro de la escala social es, quizás, el aporte más importante que desde los estudios culturales pueden dar a trabajos en comunicación. La pregunta por el otro y toda la dimensión política que habilita la mirada desde los estudios culturales significa poner sobre la mesa las propias demandas del investigador y sus intereses. 
Vamos a ver como el cruce de ambas perspectivas habilita a pensar la construcción de un conocimiento situado que empiece a preguntarse por los estatutos sensibles, personales y propios de cada investigador y su disciplina científica y en diálogo constante con su entorno.

¿Cómo viven estos sujetos la experiencia narrativa del abuso sexual infantil en estas situaciones comunicativas y con estos interlocutores específicos? La práctica del contar -en situaciones ficticias como las propuestas- tiene un sentido que no puede ser percibido o analizado si no es posicionado y visto en condiciones de producción (y recepción) específicas. Ese contar/relatar significa "algo" para los sectores involucrados. No lo mismo pero ese "significar algo" es lo que nos interesa aquí.

\section{Estudios de Género y Sexualidad.}

Los Estudios Poscoloniales de Género

Por otro lado, y dentro de los estudios de género y sexualidad, los Estudios Poscoloniales de Género -o los feminismos de la tercera ola- que dan cuenta de los debates por la deconstrucción de la categoría de "mujer". Las mujeres de color instalan sus discusiones y parten de señalar y acusar al feminismo occidental como igualmente avasallante e invisibilizador que aquello que denuncian: el patriarcado (Bidaseca, 2012). ¿Existe la mujer como tal? Se cuestiona Butler (1999) el movimiento feminista dio por hecho el empalme de cierta identidad común entendida bajo la categoría de "mujeres", no solo esto sino que calibró intereses y metas al interior de ese gran conjunto que es el movimiento feminista sin reparar en diferencias y desigualdades propias de la diversidad.

Tal como define Elizalde (2013) “[...] (la) identidad como instancia de identificación, posicionamiento y antagonismo, lo cual supone pensarla como terreno de lucha por el sentido político de sus términos, y como una instancia procesual, un permanente estar siendo y haciéndose en la cultura." Esto es, la identidad como lugar legítimo para la construcción de un conocimiento situado, específico. Si de algo nos sirven las herramientas analíticas que los feminismos poscoloniales ofrecen es para cuestionar la misma norma en la que se instalan. La relevancia de la experiencia de las mujeres de color sirvió para criticar todo un sistema que se autopercibía como 
transgresor, diferente y disruptivo, la reflexión situada, política y experiencial puso en jaque aquello que se postulaba como diferente y alternativo de un sistema patriarcal opresor. Entonces, ¿es posible extraer algún tipo de saber de la experiencia (traumática) y utilizar ese mismo insumo como reflexión metodológica para el estudio comunicacional de relatos de experiencias traumáticas?

"Cualquier discusión sobre la construcción intelectual y política de los feminismos del tercer mundo debe tratar dos proyectos simultáneos: la crítica interna de los feminismos hegemónicos de 'Occidente', y la formulación de intereses y estrategias feministas basados en la autonomía, geografia, historia y cultura." (Mohanty, 2008, p. 117)

El primero de los proyectos a lo que refiere trata de cuestionar y deconstruir todo lo señalado por el feminismo de Occidente hasta ese momento, y lo segundo es construir y repensar nuevas categorías ancladas en un espacio y tiempo, inmersa en la red de sentidos que determinan las condiciones de producción de esos conceptos.

Los feminismos de la tercera ola nacieron así, al calor de las críticas a la categoría misma de "mujer" pensada como sujeta universal. Las bases de los feminismos contemporáneos son críticas a las categorías que nacieron en los primeros debates al interior del movimiento durante la Primera y Segunda ola ${ }^{22}$. El mismo que pone el ojo - precisamente- en las diferencias entre las mujeres, es el caso de los feminismos del tercer mundo o descoloniales. "La teoría feminista -analiza Butler- ha supuesto que existe cierta identidad, entendida mediante la categoría de las mujeres, que no sólo incita los intereses y las metas feministas dentro del discurso, sino que constituye al sujeto para el cual se procura la representación política" (1999, p. 33). Para

22 Si bien es un debate de la historiografía feminista, hay quienes cuestionan la existencia de "olas" para dar cuenta de los procesos de cambio del movimiento y hay quienes las citan para dar cuenta de grandes caracterizaciones para facilitar los análisis. En principio, y de manera esquemática, podríamos decir que la primera ola emerge a fines del siglo XIX y principios del siglo XX, teniendo como principales objetivos el acceso de las mujeres a los derechos civiles y políticos. En la segunda ola, que emerge en EEUU y Europa en los 60, las demandas se concentran más en los derechos que tienen que ver con la autonomía sexual y reproductiva, hay mayor conciencia sobre la imposibilidad de referirse a "la mujer" como si no existieran diferencias de clase, etnicidad, orientación sexual, edad, entre LAS mujerES (Fellitti). 
esta autora, el género "es, de suyo, una formación discursiva y el efecto de una versión determinada de la política de representación. De esa manera, el sujeto feminista resulta estar discursivamente constituido por el mismo sistema político que, se supone, facilitará su emancipación” (34). El análisis de Butler deconstruye completamente la categoría de "género" y pone en cuestión el mismo estatuto heteronormativo dominante hasta en la misma teoría feminista que presupone una identidad entre género/sexo/ deseo basado en el binarismo masculinidad/feminidad. En ocasión de un seminario de posgrado en la UBA, Alejandra Oberti dio cuenta de este concepto en términos metafóricos, bien práctico: “diríamos que Butler piensa al género como un vestido que es posible sacar y volver a poner."

Entonces, y con la crítica y el ojo puesta en las desigualdades, Delfino (1999) nos propone un primer cruce entre estos estudios y los EC al traer el problema del subalterno (Spivak, 2011) y su ubicación en estos mapas hegemónicos estructurales, va a decir que el subalterno nunca coincide de forma homogénea con el lugar que se le atribuye sino que "interseca una lucha de posiciones, instituciones y pactos". Las luchas serán, no por los lugares o posiciones dentro de la escala sino, por el sentido de las relaciones que se establecen entre esas posiciones. Aquí vemos la relación crítica entre los materiales simbólicos y el valor cultural (Delfino, 1999, p.68), es esta lucha la que va a orientar la actividad teórica. "Cuando las mujeres, los gays o los indígenas producen una intervención esta ya está inscripta en un debate actual sobre consenso e incorporación hegemónicos” (Forastelli, 2008, p. 106), ¿cuánto de esa experiencia y conciencia real de los lugares de enunciación es sensible de ser utilizada para la producción del conocimiento? Entonces, el motor reflexivo será la conciencia de los lugares y es la experiencia consciente transformada en insumo, factor o elemento para la construcción del conocimiento científico. Al parecer, estamos un poco más cerca de responder la pregunta inicial acerca del valor epistemológico de los lugares o posiciones que devienen en experiencias de los sujetos.

Entonces, y para cerrar provisoriamente, la construcción del mapeo analítico a partir de estos estudios (EC y Estudios Poscoloniales de Género) tiene que ver con politizar los lugares de construcción y enunciación del conocimiento sobre el otro. El debate epistemológico y metodológico será a partir de la pregunta por el mismo estatuto que habilita a construir conocimiento sobre otro. Hablar y pensar sobre un otro encierra siempre debates sobre legitimidad y ética, las preguntas no son nuevas pero ameritan 
tenerlas bien presente: ¿tiene legitimidad epistemológica el conocimiento construido bajo las mismas categorías colonizadas (en términos de Clifford) que denunciamos en el mismo movimiento? Los Estudios Poscoloniales y los EC vienen a salvar esta gran encrucijada ofreciendo un escape: la conciencia real de los lugares de privilegio y políticos que ocupamos dentro de la escala social. Es a partir de allí que observamos y enunciamos. 


\section{Categorías Analíticas:}

Sobre Narrativas de lo indecible. Cruces teóricos con la comunicación

"No se notó acaso que la gente volvía enmudecida del campo de batalla? En lugar de retornar más ricos en experiencias comunicables, volvían empobrecidos. Todo aquello que diez años más tarde se vertió en una marea de libros de guerra, nada tenía que ver con experiencias que se transmiten de boca en boca." (Benjamin, 2013, p. 2)

Benjamin se refiere aquí a la experiencia colectiva e individual de las Guerras Mundiales ¿Cómo una experiencia tan rica, fuerte, dolorosa en términos de vivencias sufrió un repliegue total en términos narrativos? ¿Qué significa que no pueda ser contada la experiencia? Ante este repliegue o ausencia de la narración cabe preguntarnos si estamos ante un repliegue de la experiencia en términos vivenciales, ¿duele menos aquello que no es contado? Benjamin refiere al trabajo artesanal del narrador con su materia prima que es la vida ¿Cómo es ese proceso de semiotizar lo intangible, la experiencia? Para este trabajo el proceso de narrar será eso: un proceso. El mismo como constitutivo del sujeto social pero con el foco puesto en uno de sus núcleos: el dolor. ¿Es posible contar/comunicar el dolor? ¿en qué medida es transferible?

Si el lenguaje ingresa en la vida a través de enunciados concretos y es a través de enunciados concretos que la vida ingresa en el lenguaje (Bajtín, 2011) no es muy exagerado preguntarnos por el orden primero del relato o la experiencia, es como el huevo o la gallina. Si somos en la medida en que podemos narrarnos, ¿qué sucede con todo aquello que no puede ser narrado?, ¿nuestros silencios son proporcionales al olvido o tienen que ver, más bien, con la negación de contarnos en esos términos? El quiebre aquí no sólo es emocional y corporal a raíz de la experiencia del abuso sexual sino -y sobre todo- narrativo. Esto último nos lleva a pensar rápidamente en que si no hay relato, tampoco hay experiencia puesto que esta se termina de constituir en su relato, se termina de vivir durante el proceso del narrar. No por nada las profesionales dicen que contar un abuso es volver a vivir la experiencia del miedo, del dolor, de la angustia. Es en ese momento que toda la existencia de ese sujeto tendrá como núcleo narrativo el dolor, saben que están allí para hablar de aquello que les duele. Aún cuando la 
entrevista se creó con el objetivo de dar espacio suficiente al niño/a para contar o no hay nadie que apure en las reuniones de pares, aún cuando son niños y niñas muy pequeñas y no se les pregunta directamente por los episodios de violencia o no tienen la obligación de hablar ni bien llegan al grupo de pares, aún cuando son terapeutas entrenadas o que todas las personas atravesaron por la experiencia del abuso sexual, aún así e irremediablemente esa situación de entrevista y de reuniones de pares se pensó, creó y planificó para dar o escuchar un relato que -por lo menos- causó dolor y están allí para contarlo.

"Rara vez se toma en cuenta que la relación ingenua del oyente con el narrador está dominada por el interés de conservar lo narrado. El punto cardinal para el oyente sin prejuicios es garantizar la posibilidad de la reproducción. La memoria es la facultad épica que está por encima de todas las otras. Únicamente gracias a una extensa memoria, por un lado la épica puede apropiarse del curso de las cosas, y por el otro, con la desaparición de éstas, reconciliarse con la violencia de la muerte." (Benjamin, 2013, p. 10)

La escucha y la retención de aquello que fue oído será aquí la relación entre nuestro oyente y narrador. Sobre todo cuando hay un uso instrumental de aquello que fue oído, nada debe dejarse escapar. Más que nunca hay una intencionalidad de reproducir aquello que pudo ser -finalmente- enunciado en esta situación comunicativa, aún sin "relato" articulado coherentemente para las partes intervinientes, las especialistas presentan aquello que fue dicho o hecho dentro de la cámara. Siempre con su previa traducción por supuesto, pero el objetivo primero (en el caso) de la cámara gesell fue su capacidad para grabar y retener todo lo que haya sido dicho dentro de ella. Aún si aquello que se busca no fuera dicho, las especialistas sostienen que "eso" siempre está (en referencia al relato latente) que a través de los diferentes testeos pueden acceder a ese lugar inaccesible e inenarrable y compartirlo. En el Capítulo 3 nos referimos más extensamente a este punto pero por ahora esto: en la primera situación comunicativa la relación entre oyente y narrador será la creación de las condiciones necesarias para que pueda ser enunciado el relato y su retención y posterior reproducción, mientras que en la segunda situación comunicativa será sólo la de reproducción. 
Si bien la primera situación comunicativa es el ejemplo más “evidente", es pertinente preguntarnos por esta capacidad de retención o reproducción de lo escuchado desde una escucha científica o una solidaria de pares. Ya desde el inicio y el objetivo primero de este grupo es el de escuchar, plantean una "ayuda" en términos no específicos que se resuelve en escucha. Una escucha que se retiene y se reproduce. Al margen de que los Adultos supongan que el relato no sale de ese grupo, es en la enunciación de sus testimonios en el espacio público donde se reitera y comparte esto que fue escuchado al interior del grupo. $\mathrm{Y}$ para nosotras esta pregunta por lo metodológico que nos atraviesa se resuelve en la habilitación de espacios de escucha con las personas que intervienen en nuestra investigación. Codificado, traducido, complejizado pero reproducido en fin en estas líneas que buscan ser un trabajo de tesis doctoral. Pero, ¿cómo aquello que no fue dicho o contado puede ser compartido?

"Más que indagar sobre la memoria me interesaba lo inolvidadizo, según la feliz expresión de Nicole Loraux, aquello activo y punzante, performativo, capaz de conformar y subvertir el relato, de aparecer sin ser llamado en una simple conversación, en una actualidad que convive con lo cotidiano aun sin emerger, sin mostrarse, formando parte de la historia común y de cada biografía." (Arfuch, 2013, p. 14)

Aquí es el cuerpo quien va a hablar, si no hay huellas físicas de ese daño, no hay palabras es la psiquis la que emerge y "cuenta" lo que no fue dicho con palabras, pero no cualquiera puede leer esa psiquis y entenderla: este es el objetivo de la batería de tests. Para Leonor Arfuch se trata de lo "inolvidadizo", a nivel corporal y performativo aparece (pero nunca se fue), que tiene un origen preciso (el inicio de las situaciones de violencia) y aún no sabemos en qué va a desembocar aquello que no puede ser olvidado. Ya estamos en condiciones de decir que a nivel científico académico aún no hemos podido nombrar eso que se nos escapa entre los relatos del horror, aún hay algo en el plano experiencial que no cabe en categorías lingüísticas, es tan grande que no puede colarse entre los formatos que le ofrecen para habitar. 
¿Pueden comunicólogas y comunicólogos ayudar a desenredar estos nudos narrativos para una justa intervención de los organismos encargados de velar por las seguridades de niños, niñas y adolescentes? ¿Cómo y desde dónde trazamos los puentes para el trabajo colaborativo?

\section{¿Qué es una situación comunicativa?}

Dijimos que la entrevista es una situación comunicativa creada para el contar. Es todo lo extraverbal de la enunciación, dirán Bajtín y Voloshínov.

"Acordemos llamar con un término que ya es conocido, situación, a los tres aspectos sobrentendidos de la parte extraverbal de la enunciación encontrados por nosotros: el espacio y el tiempo en el que ocurre la enunciación -el dónde y el cuándo-, el objeto o el tema sobre el que ocurre la enunciación-aquello de lo que se habla- y la actitud de los hablantes frente a lo que ocurre -la valoración." (Bajtín, 1998, p. 59)

Si cada enunciado se compone de una parte verbal y otra extraverbal, necesitamos de la segunda para terminar de comprender a la primera. Un niño sentado en una silla con una mujer enfrente sentada en otra silla llora diciendo yo no hice nada... ¿qué puede significar esa frase: yo no hice nada? Más allá de significados literales de cada palabra el sentido de esa frase lo termina de dar todo el contexto extraverbal: ¿dónde están?, ¿quién es ese niño y qué rol cumple esa mujer allí?, ¿cuándo fue ese episodio y en el marco de qué? Lo contextual y lo situacional encierran el sentido de la expresión.

Con esto resulta claro que la diferencia de sentidos lo dan las situaciones comunicativas, la diferencia de sentidos de una misma expresión verbal va a depender de la situación comunicativa en la que se enmarque, esto es: tiempo, espacio, tema y valoración. "Estamos convencidos de que cada discurso es dialógico, dirigido a otra persona, a su comprensión y a su efectiva o potencial respuesta" (Bajtín, 1998, pp. 5455). Es esta orientación hacia un otro lo que supone el registro de jerarquías y posiciones dentro de la escala social, de poder, entre ambos interlocutores. 
Cualquier enunciado va a cambiar de acuerdo a la posición social del oyente y/o hablante/ auditorio, "la orientación social es una de las fuerzas organizadoras vivas que, junto con la situación de la enunciación, constituyen no solo la forma estilística de ésta, sino también su estructura puramente gramatical” (ídem, p. 55). Dicho esto, nunca un mismo enunciado significa lo mismo cuando varían las situaciones comunicativas.

Para acceder a los sentidos que forman parte de esa experiencia narrativa, vehiculizados a través del lenguaje no basta únicamente con interpretar los dichos sino las condiciones en que esos dichos adquieren sentido y significado. "Los modos de disposición del relato implican una articulación entre la puesta en lenguaje de las experiencias narradas y los dispositivos culturales que permiten su interpretación" (Fernández, 2015, p. 2). Más allá de las convenciones, normas y valores que regulan y atribuyen significado a nuestras prácticas comunicativas (Von Sprecher, 2008), es el contexto de enunciación el que termina de "cerrar" el sentido, es el elemento fundamental para comprender hacia dónde va y que significa esa práctica.

Es en esta articulación donde tendremos que prestar mucha atención, serán en estos intersticios donde la verdadera lucha por los sentidos se dará. Veremos como la pugna por los sentidos y sus posteriores consecuencias serán en terrenos aparentemente mínimos pero que en perspectiva son inmensos. ¿Es suficiente -en términos legalesacceder a la experiencia narrativa de los/as sujetos/as para dar cuenta de las consecuencias traumáticas del incesto? ¿cómo es esa disputa por los sentidos del daño? La disputa por el sentido del daño será el trasfondo comunicacional en ambas situaciones comunicativas. La comunicación será entendida como la arena de lucha por los sentidos de lo social (Martín Barbero, 2003) y en esa arena de lucha se juega, entre otras cuestiones, el sentido y significado del daño y si alguien -en términos criminaleslo provocó. Ambas situaciones comunicativas son puestas en escena de las luchas de sentido y es objetivo nuestro ver cómo se configuran esas luchas bajo las dinámicas específicas de cada situación.

Hay un tira y afloje entre lo "comprobable", lo "verídico", la fabulación, la mentira y el daño que se van a instalar precisamente en esta articulación de la que nos habla Fernández, a partir del narrarse a una/o misma/o veremos el proceso de pugna y las estrategias de enunciación de cada sujeto. Las narrativas nos permitirán acceder a este proceso del contarse y convertirse en relato para disputar el sentido de lo doloso, lo justo e injusto. ¿Cómo se demuestra discursivamente el dolor en cada situación? 
“(...) no se puede soslayar el papel y la importancia de la narración, como matriz mnemo-semiótica primordial (de significación / comunicación y de configuración genérica), gen-ética que permite dar rienda suelta a nuestro 'carácter destructivo' y relde-constructivo, cuya posición privilegiada se sustenta por su potencialidad para mediar la experiencia, experimentar de (otros) modos, ensayar la alteridad, comprender la otredad; explotar y desplegar." (García, 2004, p. 20)

Es el proceso en que nos transformamos en relato ubicándonos en tiempo y espacio, la experiencia debe ser narrativizada/semiotizada para ser compartible en distintos formatos que circulan algunos más fluidos que otros, pero que circulan en fin. El desplazamiento del sentir experiencial al relato, a historia, es donde nos interesa poner la mirada, es a través de ese proceso de narrativización que convertimos en una secuencia temporal -espacial lingüística articulada (relato) aquello que sufrimos, nos alegramos, no entendemos, si entendemos, lo nuevo lo viejo. Resulta ser un campo de batalla donde se despliegan distintas estrategias lingüísticas y corporales que se juegan por la credibilidad de la víctima o del abusador/a. "La narración es una forma para convertirnos a nosotros y a los otros en historias que nos devuelven en forma de experiencia a la vida cotidiana" (Rincón, 2006, p. 14). Somos historias y es a través de historias que son tenidas en cuenta las víctimas de abusos, quien logre enunciar lo más ajustadamente posible a las reglas/formas/dinámicas/estándares de cada institución "ganará la batalla". En la primera escena comunicativa como relevancia de pruebas, en la segunda como conversión de la experiencia a testimonio de vida.

Con el pasar del análisis veremos cómo cada relato va a ser tenido en cuenta más por su estilo que por su contenido, su estilo va a primar en algunas oportunidades y, dentro de este estilo, las formas en que se construye su veracidad va a ser lo más importante en ese relato. No va a importar tanto qué se dice, sino cómo se lo dice y en qué medida va a cumplir con los requisitos específicos que cada situación comunicativa habilita y autoriza para el contar. 


\section{Las Narrativas Experienciales que devienen en Testimonios}

Al empezar este apartado pensaba qué debates entran a dialogar en estas tramas científicas: Autoridad Narrativa, testimonio, el problema de la ficción, memoria(s).... Mucho, pero vamos por partes: ¿Quiénes tienen "autoridad” y cómo pueden hablar del ASI (Abuso Sexual Infantil)? ¿Quién(es) son las voces autorizadas? ¿Quiénes son los subalternos en estas tram(p)as? ¿Pueden hablar en el contexto de estas instituciones/organizaciones con características tan rígidas? $\mathrm{Y}$ aquellas/os que no pasaron por la experiencia del abuso sexual ¿tienen derecho, sus voces, a aparecer en estos diálogos íntimos pero colectivos también?, ¿tenemos derecho de traducir sus prácticas con nuestras categorías analíticas?

Entre estos debates existen puntos de contacto como las dificultades de dar cuenta del otro/a, de la violencia académica que significa ubicar a los otros dentro de nuestras categorías lingüísticas académicas, de la "domesticación" -de las prácticas / narrativas / sentires-, que buscamos codificar en un lenguaje académico/articulado. ¿Cómo es posible que busquemos nominar bajo las mismas categorías que denuncian su opresión y buscan su deconstrucción? Son puntos de la cuerda donde buscaremos torcer un poco más este problema, nudos obligatorios para seguir pensando (y sintiendo) esta problemática.

"La situación de narración en el testimonio envuelve una urgencia de comunicar, un problema de represión, miseria, subalternidad, encarcelamiento, lucha por la supervivencia, implicado en el acto mismo de la narración" (Beverley, 2004, p. 103). Los trabajos de género y dictadura de autoras como Oberti, Capurro Robles, Skura y Bacci, problematizan esta noción de testimonio, es extraer la experiencia para volverla testimonio, dirá Oberti. Extraer la experiencia. Ellas trabajan con testimonios de mujeres que participaron en grupos armados durante los 70-80 en la Argentina. Van a decir que es posible identificar un doble uso de los relatos pertenecientes a ex presas políticas en centros clandestinos de detención: en primer lugar es un uso reparador (intimísimo) para la narradora, pero advierten que sería un efecto potencial de reparación... Y un segundo uso, el uso instrumental que desde las partes (intervinientes en un proceso judicial) hacen de los testimonios/pruebas. Así esta "encrucijada ética" nos pone en alerta sobre los modos de decir, de callar, de narrar y de sentir del otro, más allá de las buenas intenciones que cualquiera tenga, hay que estar atentas a cómo y dónde se configuran estos discursos. 
Las sobrevivientes en estos trabajos son mujeres adultas que tuvieron la posibilidad de reelaborar sus relatos luego de años de haber salido de cautiverio (última dictadura cívico-militar). Dato no menor a la hora de pensar el juego entre ficción e historia que aparece inexorablemente como un problema (Sklodowska, 1982). Son testimonios de una contribución importante para la reconstrucción histórica de un país que posee características y formatos bien específicos. Para continuar con los nudos, hilamos la idea de "renuncia al yo" (Arfuch, 2013) que para testimoniar estos relatos trasciende la particularidad biográfica y -quizás- el dolor íntimo/personal para convertirse en una herida histórica. En un eslabón más de una de las memorias colectivas. Estos testimonios ya forman parte de una historia del país, su uso ya es colectivo y sus interpretaciones también.

En este contexto los modos del contar y de enunciación cobran particular relevancia ya que son ellos quienes imponen una forma (narrativa) a la experiencia (Arfuch, 2013). En estos modos del contar las situaciones comunicativas lo son todo: moldean la experiencia sensorial de acuerdo a las categorías lingüísticas disponibles. Y paradójicamente nuestra mirada busca ver aquello que no se puede decir, que no se puede nombrar, que no se puede compartir, lo más intransferible: ¿Se puede comunicar El Dolor? ¿Cómo se cuenta lo incontable? ¿Es posible ponerle palabras a aquello inaprensible, inverosímil? ¿Qué formatos y categorías lingüísticas disponibles hay para esta traducción/codificación/pasaje de formas? "¿Qué pasa si la mayor parte de la historia de Rigoberta no es cierta?” Con esta pregunta el antropólogo David Stoll pone en duda no sólo la veracidad de los dichos de Rigoberta Menchú sino su autoridad narrativa acerca de los suplicios que sufrió su pueblo en Guatemala. Me llamo Rigoberta Menchú fue acusado de no pertenecer al género testimonio ya que "no es el recuento de un testimonio presencial”, como dice serlo (Stoll en Beverley, 2004, p. 103)

Distinto a los casos con los que trabajamos, estas tensiones aparecen cuando nos preguntamos ¿quiénes pueden narrar lo que vivieron?; y siguiendo con la discusión sobre los formatos, géneros y sus modos: ¿Cómo deben ser esos testimonios/relatos? ¿En qué formatos? ¿Mediante qué estrategias discursivas para que sean tenidos en cuenta? 
"De este doble análisis resulta que la ficción, principalmente la ficción narrativa, es una dimensión irreducible de la comprensión de sí. Si es cierto que la ficción sólo se completa en la vida y que la vida sólo se comprende a través de las historias que contamos sobre ella, entonces, podemos decir que una vida examinada, en el sentido de la palabra que tomamos prestada al principio a Sócrates, es una vida narrada.” (Ricoeur, 2001, p. 20)

Veremos como la ficción narrativa será una preocupación constante no solo para nuestros/as autores/as sino para los organismos encargados de velar por los derechos de niños, niñas y jóvenes. El relato será juzgado en términos morales de verdad/mentira. En el caso de los adultos ya se juegan otras cuestiones pero la ficción va a ser entendida como mentira o fabulación para las partes que intervienen en unjuicio.

Si bien la realidad está constituida discursivamente (Hall, 2010), el discurso es un hecho social que produce efectos bien reales que atraviesan, en este caso más que nunca, la subjetividad de los sujetos. Si bien Hall se mueve por terrenos de Marx, a nosotras nos ayuda a pensar las "opciones axiomáticas" en cruce con nuestro análisis a partir de preguntas como: ¿desde dónde miramos, pensamos? ¿qué lugar político, de privilegio ocupamos en la reconstrucción de las tramas narrativas académicas, en la construcción del "saber"?

Y por último, no hay nada más político que transparentar nuestros intereses en el proceso de construcción de saberes, del conocimiento: ¿cómo damos cuenta de la incapacidad del lenguaje académico para comprender, para nominar algunos procesos internos que atraviesan y constituyen a los sujetos? ¿Estamos, quizás, ante una crítica al modelo científico que se muestra -por momentos- incapaz de abarcar con sus categorías muchos procesos que tienen que ver con la experiencia traumática?

Este ser relatos es la acción/proceso que va más allá de concebir a los mismos como formas de representarnos, el narrar es la manera en que nos constituimos como sujetos y es por esto que la narrativa como fenómeno comunicacional constituye una ventana para el estudio epistemológico de los fenómenos sociales (Mumby, 1993/1997). Es a través del estudio de narrativas que accedemos a ese universo simbólico y su descentramiento a partir de la experiencia del incesto o abuso sexual durante la infancia. 
"No hay un sujeto o una vida que el relato vendría a representar sino que ambos -el sujeto, la vida- en tanto unidad inteligible, serán un resultado de la narración. Antes de la narración solo habrá ese sordo rumor de la existencia, temporalidades disyuntas en la simultaneidad del recuerdo, la sensación, la pulsión y la vivencia" (Arfuch, 2013, p.75). No estamos tan preocupadas por nombrar aquello innombrable sino por dar cuenta de esa incapacidad y ansiedad del investigador/a por etiquetar todo en el campo científico. No es buscar los relatos representativos sino ver cómo se articulan en determinadas situaciones conformando la vida misma.

"La narrativa se encuentra atravesada por relaciones de poder, por dimensiones ideológicas vinculadas con la vida práctica y las grandes esferas de la vida social; simultáneamente, la narratividad se dispone como un dispositivo constitutivo de esas relaciones, un elemento primordial en la legitimación de imaginarios sociales, donde las tensiones pueden soslayarse o complejizarse [...]." (Fernández, 2015, p. 21)

Con esta misma inquietud, nos interesa los modos en que esa experiencia es enunciada en determinadas escenas comunicativas, cómo el lenguaje (y las concesiones que presta cada escena) configuran la experiencia según los estándares disponibles para el compartir (Arfuch, 2013). Si partimos de esta base para considerar a la narrativa como motor de la experiencia estamos en condiciones de decir que cada situación comunicativa va a establecer las lógicas y dinámicas del sentir la experiencia traumática, ¿hasta dónde es posible contar el dolor? ¿Cómo viven la experiencia narrativa del incesto? ¿Cuál es el núcleo narrativo de esos relatos?

"Si de algún modo las narrativas del yo nos constituyen en los efimeros sujetos que somos, esto se hace aún más perceptible en relación con la memoria en su intento de elaboración de experiencias pasadas, y muy especialmente de experiencias traumáticas. Allí, en la dificultad de traer al lenguaje vivencias dolorosas que están quizás semiocultas en la rutina de los días, en el desafío que supone volver a decir, donde el lenguaje, con su capacidad performativa, hace volver a vivir, se juega no solamente la puesta en forma -y en sentido- de la historia personal, sino también su dimensión terapéutica -la necesidad de decir, la narración como trabajo de duelo- y fundamentalmente ética, por cuanto restaura el circuito de la comunicación -en presencia o en la ausencia que supone la escritura- y permite escuchar, casi corporalmente, con toda su carga significante en términos de responsabilidad por el Otro." (Arfuch, 2013, p.76) 
Arfuch nos devuelve no solo la responsabilidad ética que supone la escucha del otro, sino someter el cuerpo a sufrir de nuevo la experiencia traumática. Es evidente a esta altura decir que la cámara gesell como dispositivo de almacenamiento es insuficiente. Por supuesto que fue pensada como soporte de almacenamiento para este sistema penal y judicial y en base a eso funciona, pero no contempla la densidad de un relato por fuera del hecho concreto al que intenta arribar. De hecho, para la cámara y para este sistema, el hecho empírico se convierte en el eje narrativo de cualquier relato enunciado allí. La experiencia no aparece con sus matices más sutiles, solo interesa la narración de los hechos, hay toda una dimensión de lo sensitivo que se pierde o no encuentra donde colarse y que -a diferencia de las reuniones de pares- el dispositivo no flexibiliza sus formas para dar lugar. Distinto es el caso de la segunda situación comunicativa donde es la misma situación comunicativa que se adapta a las formas del contar de sus participantes.

Pero, ¿cómo estas narrativas devienen en Testimonios de Vida? Como dijimos, Beverley reflexiona sobre el caso de Rigoberta Menchú e introduce a Stoll en sus discusiones, entiende (Beverley) por testimonio "una narrativa (...) contada en primera persona por un narrador que es también un protagonista o testigo real de los eventos que él o ella cuenta [...] La palabra testimonio traduce literalmente el acto de testificar o de ser testigo en un sentido legal o religioso [...].” (1996, p. 103)

David Stoll en su libro "Me llamo Rigoberta Menchú" (que apareció a fines de 1998) se refirió a la definición de Beverley de testimonio (citado anteriormente), Stoll argumenta que "juzgado por tales definiciones, Me llamo Rigoberta Menchú no pertenece al género del cual es el más famoso ejemplo, porque éste no es el recuento de un testigo presencial como afirma serlo" (1999, p. 242). En realidad, "lo que Stoll es capaz de demostrar es que algunos detalles y no 'la mayor parte' de la historia de Menchú pueden ser lo que él llama 'una invención literaria'” (Beverley, 2004, p. 103). Aquí aparece uno de los primeros debates/interrogantes cuando hablamos de testimonios, la cuestión de la ficción. Entendida por Bruner (2003/2013) (la ficción literaria) "no se refiere a cosa alguna en el mundo, sino que sólo otorga su sentido a las cosas. Es justamente ese sentido de las cosas el que hace posible a continuación la referencia a la vida real." 
Estas narrativas, incluso las de ficción, dan forma al mundo real, son una matriz para pensar y formular los relatos. Y son con los aportes de Bruner que pensamos a los relatos como moldes de la experiencia, confeccionan la experiencia y la pensamos a partir de ellos, es por eso que nos preguntamos e introducimos un hilo más a este ovillo: ¿qué aparece primero: la experiencia o el relato? Porque el narrador, dirá Benjamin, "su talento es de poder narrar su vida y su dignidad; la totalidad de su vida. El narrador es el hombre que permite que las suaves llamas de su narración consuman por completo la mecha de su vida” (Benjamin, 1986, p. 17). ¿Qué relación tiene el narrador con su materia prima que es la vida?, se pregunta. Y es que el narrar involucra a mucha más que la propia voz, Benjamin lo relaciona con un trabajo más bien artesanal, ¿no será, acaso, labor del narrador elaborar la materia prima de la experiencia -la propia y la ajena- de forma sólida, útil y única? (ídem).

\section{¿Qué lugar tiene la experiencia en estas d(t)ramas?}

Cruces teóricos con los Estudios de Género

Y tratando de ajustar aún más la pregunta que abre este apartado: ¿Qué papel cumple la experiencia en la elaboración de estas tramas científicas? ¿Qué conocimientos podemos extraer/pensar/elaborar/reelaborar a partir de pensar la centralidad epistemológica de la experiencia? Las reflexiones son muchas y vienen de varios lugares; desde quienes abogan por una deconstrucción total de la experiencia corporal para cuestionar las ideologías dominantes de opresión de género y de las sexualidades, hasta aquellas que la reivindican como los cimientos de las teorías feministas y queer, como respuesta o prueba de las explicaciones que se puedan llegar a dar. De uno u otro(s) lado(s) la pregunta por la experiencia corporal como insumo a las reflexiones sobre /desde los sectores oprimidos sigue constituyendo un interrogante en esta clase de estudios. Aquí, la pregunta por la autoridad epistemológica y la crítica metodológica merece repensar la relación entre experiencia corporal, el lenguaje y el conocimiento.

La primera que traemos para entrar en discordia es a Joan Scott. En su artículo titulado así (Experiencia) la autora advierte de tomar a la experiencia como un hecho en sí mismo, deshistorizado y descontextualizado, marcado por la subjetividad ideológica. 
Poner al descubierto la experiencia de grupos oprimidos deja ver los procesos de opresión que rigen sobre ellos pero no su lógica ni mecanismos internos.

"No son los individuos los que tienen la experiencia, sino los sujetos los que son constituidos por medio de la experiencia. (...) (la misma) se convierte (así) no en el origen de nuestra explicación, no en la evidencia definitiva (porque ha sido vista o sentida) que fundamenta lo conocido, sino en aquello que buscamos explicar, aquello acerca de lo cual se produce el conocimiento." (Scott, 2011, pp. 8-9)

Pensar de este modo, sostiene la autora, es darle historicidad a la reflexión. Alcoff (1999) hace esta misma lectura de Scott, los peligros de adherir a una postura contraria a esta es pensar el lugar de la ideología falocéntrica como parte de la experiencia, es el foco, matriz de reproducción de los mecanismos de opresión que intentamos denunciar. Esta postura (la de Scott y otras), que forma parte del feminismo postestructuralista, resta importancia cognitiva al valor de la experiencia como parte del proceso de conocimiento para correr el foco hacia el análisis textual y del lenguaje, es decir, a la interacción de discursos.

Siguiendo con estos alertas sobre la esencialización de la experiencia y la percepción -y complejizando aún más estos términos que parecieran ser bien rígidos- las exponentes del feminismo poscolonial, entre ellas Chandra Mohanty, nacieron al calor de las denuncias por la homogeneización de las experiencias de las mujeres. Insisten: "las mujeres". Alertan sobre pensar a las mujeres del "tercer mundo", "postcoloniales", o "negras" a partir del discurso académico hegemónico de Occidente, "la conexión entre las mujeres como sujetos históricos y la representación de Mujer producida por los discursos hegemónicos no es una relación de identidad directa, ni una relación de correspondencia o simple implicación. Se trata de una relación arbitraria" (Mohanty, 2008, p. 115). Fueron las experiencias (distintas) a las denunciantes de Occidente que se levantaron en voz para dejar en claro que las experiencias y las percepciones no eran las mismas. Que ellas querían pensarse a partir de categorías propias distintas a las del discurso hegemónico, que las mujeres no (somos) son todas iguales y es preciso hacer estas distinciones. 
“(...) las obras del feminismo de occidente sobre las mujeres del tercer mundo deben ser consideradas en el contexto de la hegemonía global de la academia occidental, es decir, la producción, publicación, distribución y consumo de información de ideas." (Mohanty, p. 118)

Si seguimos hilando en este mismo nudo podemos citar a Haber y Figari (2011) que retoman los apuntes de Haraway, quien cree firmemente en localizar la posición desde donde se enuncian los análisis, si bien la identidad -autoidentidad(1999) no produce ciencia, el posicionamiento crítico sí... es la objetividad, transparentar quién habla, desde dónde, bajo qué perspectiva, con qué influencias, es decir, su experiencia. En términos comunicacionales, un lugar de enunciación (Bajtín) es ese lugar social-discursivo y de sentido desde donde uno habla, dónde se empieza a construir la difícil relación con el otro.

En las últimas líneas se deduce la importancia de la experiencia y la percepción como el lugar desde donde hablar, determinante a la hora de pensar y analizar. La experiencia aquí es el camino para empezar a trazar un conocimiento situado, responsable con el lector/decodificador, dando las coordenadas de lectura para seguir los razonamientos de quien escribe. Acá la experiencia no es motivo, resultado ni prueba cognitiva sino contexto de enunciación de los discursos. Forman parte de los materiales de estudio, de análisis. Aun así, sobrevuela la idea del lenguaje y el análisis de estos discursos como salida para sortear estos obstáculos de la reproducción de las disposiciones de opresión.

Por otro lado, Alcoff hace una reivindicación de Merleau-Ponty, sugiriendo volver a darle centralidad epistemológica a la experiencia, sin olvidar los orígenes de las teorías feministas que nacieron al calor de las denuncias de opresión y discriminación desde sus experiencias. Parafraseando sus inquietudes: si le quitamos centralidad epistemológica a la experiencia, ¿qué les/nos queda (aportar) como "feministas intelectuales" al campo social y académico? Así adhiere De Lauretis en "Alicia ya no" (1992) "La dificultad real, pero también el proyecto más audaz, más original de la teoría feminista sigue siendo precisamente ese: como dar forma teórica a esa experiencia, que es a la vez social y personal, y como construir al sujeto femenino a partir de esa rabia intelectual y política" (p. 264). Me gusta esta caracterización, la rabia intelectual, la escritura y el pensamiento detonado a partir de las rabias políticas. ¿Qué más genuino 
que un inconformismo para empezar a pensar los mecanismos injustos, desiguales, violentos, censuradores que oprimen no sólo a las mujeres, sino a todos los sectores distintos al varón/mujer rico/a, occidental y cristiano/a?

En el último capítulo de "Alicia ya no", De Lauretis (1992) abre el apartado con una cita de Virginia Woolf y a partir de ese pasaje se pregunta: “¿Qué termino, distinto de instinto o de razón puede designar mejor ese proceso de comprensión, (...) ese proceso de auto-representación que define el yo como mujer o, en otras palabras, crea al sujeto como femenino? Peirce lo habría llamado hábito, como veremos. Pero yo propongo, al menos provisionalmente, el término experiencia (De Lauretis, p. 252). Dicho esto, reconoce a la experiencia como crucial para la teoría feminista en la medida que se ocupe de la subjetividad, la sexualidad, el cuerpo, y la actividad política feminista.

\section{Un Mapa Reflexivo}

Desde sus inicios este trabajo fue pensado no sólo en la "soledad" de las reflexiones de un problema de investigación que deriva en un proyecto, sino siempre en diálogo y buscando la sintonía con su entorno. Este "en diálogo" (constante) significa: integrar como materiales de análisis todo registro que sea sensible de ser reflexionado y/o contribuya a la comprensión del problema de investigación. Cuando las tramas científicas pueden ubicarse y logramos que esas coordenadas sean parte de los materiales de estudio estamos acercando al lector insumos para reconstruir el mapa reflexivo del investigador, con este mapa -o en el afán y la práctica de su armado- nos acercamos a la principal premisa de los estudios poscoloniales de género: la ubicación de las tramas científicas. Ahora bien, ¿qué significa integrar todo "registro que sea sensible de ser reflexionado"?

Venimos de formaciones distintas, de escuelas y tradiciones en comunicación específicas, de lugares distintos, de libros y PDFs variados y coloridos, cursos y seminarios de texturas y sabores bien diversos, ¿cómo construimos un problema de investigación y -en el mismo movimiento- reconstruimos las condiciones de producción de esas preguntas de investigación con esta variedad de aportes? ¿Qué aportes, de dónde, cuándo? ¿Qué contextos sociales enmarcan, contribuyen a que el flujo del pensamiento vaya por determinados senderos y no por otros? 
Esta reconstrucción de las condiciones de producción de las mismas preguntas de reflexión es el mapeo del proceso de objetivación del problema de investigación que cada investigador/a encara. Son estos insumos reflexivos los que buscamos acercar al lector. Por ahora esto: la descripción de las situaciones comunicativas abarca a las personas que intervienen en esta investigación y a nosotras mismas ¿en qué situación comunicativa fue pensada esta tesis?

A raíz del cruce de estas perspectivas, agrupamos en tres grandes grupos las preguntas que resumen el recorrido analítico del Capítulo 3. Este mapeo reflexivo habilita distintos niveles de complejidad con respecto al problema pero es este mapeo teórico-metodológico lo que nos interesa quede claro en este momento de la travesía. Las preguntas (que esperemos sean respondidas a lo largo de la tesis) serán enunciadas aquí en tres grandes grupos:

1. La experiencia como valor epistemológico: ¿Qué papel cumple la experiencia en la elaboración de las tramas científicas? ¿Qué conocimientos podemos extraer/pensar/elaborar/reelaborar a partir de pensar la centralidad epistemológica de la experiencia? ¿Cómo dialoga el mapa experiencial biográfico del investigador con el de los sujetos investigados?

\section{El pasaje de formas ${ }^{23}$. De la experiencia corporal-sensitiva al relato}

institucional: ¿Qué características (institucionales) tienen los relatos de experiencias traumáticas? ¿Quiénes pueden contar(los)? ¿Qué condiciones de producción deben tener estos relatos para que sean tenidos en cuenta en un proceso judicial?

3. Lo innombrable: ¿Podemos "soportar" no etiquetar, entender o nombrar aquello que nos aparece como desconocido al fin? A nivel enunciativo: ¿Cómo nombrar aquello que provoca una ruptura biográfica? Y para la confección de los materiales de análisis: ¿Cómo analizar aquello que no puede ser nombrado?

\footnotetext{
${ }^{23}$ El "pasaje de formas" en relación a lo que plantea Stuart Hall en su análisis "Codificar- Decodificar" de Culture, Media y Lenguaje: "En el momento en que un hecho histórico pasa bajo el signo del discurso se somete a todas las "reglas" formales y complejas a través de las cuales el lenguaje significa. Paradójicamente, el acontecimiento debe convertirse en una "historia" antes de convertirse en un acontecimiento comunicativo" (Hall, 1980, p. 130).
} 
Y desde la labor científica, siguiendo en esta línea de lo innombrable, lo intransferible, lo abyecto, lo desconocido, lo completamente otro... ¿De qué manera esa imposibilidad de nombrar nos lleva al descentramiento del análisis de los materiales de estudio? Ese descentramiento no solo desde la enunciación de la experiencia traumática sino (y en un grado de confusión no mayor, sí diferente) en la escucha científica de estos testimonios de experiencia traumática. Lo inenarrable, que resulta muchas veces ser el nudo de la narración de la experiencia traumática, aparece como obstáculo a nivel institucional en la resolución en un marco legal y un (si se quiere) llamado de atención sobre el estatuto de codificación o pasaje de formas de estos registros experienciales. $\mathrm{Y}$ es precisamente aquí donde está puesta la atención y vigilancia del investigador que busca analizar esas narrativas.

La preocupación es por el descentramiento del eje que trae la incapacidad de nominar/nombrar aquello que estamos percibiendo. Citando a autores en comunicación, aquello que no se nombra, no existe. Y la incertidumbre de no hallar categorías o colocarlas en los cajones adecuados provoca este descentramiento, es la extrañeza, la dificultad de no nombrar lo que desconcierta. "[...] nos invitan a reflexionar sobre la estrechez del discurso binario para nombrar(nos). 'Aquello que no se nombra, no existe' advierten y, a su vez, paradójicamente, 'nombrar es matar' señala Marla Morris en un texto compilado en castellano en Pensando queer. Sexualidad, cultura y educación de la editorial catalana Graó" (Pechín 2015, en Foro Debate "Género y Sexualidades"). Si bien Pechín se refiere a la "estrechez del discurso binario" para nominar a las identidades sexo-genéricas, nos valemos de esa apreciación para comprender los quiebres en el discurso y en las biografías que se encuentran huérfanas de parámetros lingüísticos.

Es en esta línea, y con esta misma preocupación, que Butler cuestiona a la misma norma para escapar a la antinomia.

“Quizás la más sugerente y sofisticada respuesta a este desafio la formuló hace unos años Judith Butler (1990), cuando en vez de quedarse dando vueltas alrededor de la tautología norma versus anti-norma (hetero versus homo; masculino versus femenino; homo versus trans, etc.) cuestionó la propia norma, su legalidad y su legitimidad como frontera que divide lo humano inteligible de lo no inteligible (y no humano), es decir, de lo abyecto." (Elizalde 2015, en Foro "Género y Sexualidades", Clase 1A) 
Este desplazamiento que pone en limpio Elizalde citando a Butler es por demás tentadora: pasar de la "norma versus anti-norma" hacia la crítica a la propia norma, o hacia el mismo estatuto que permite la codificación o el pasaje de formas de la experiencia. Con el ojo puesto en Butler es posible realizar este ejercicio de reflexión: "El sujeto feminista resulta estar constituido discursivamente por el mismo sistema político que pretende facilitar su emancipación" (Butler, 1990, p.2). En el relato de experiencia traumática en determinadas situaciones comunicativas la pregunta sería por el mismo relato de aquello que no puede ser nombrado, aquello que significó una ruptura en la subjetividad del sujeto, la misma debe ser pensada y codificada discursivamente por el mismo sistema que imposibilita su codificación o traducción a un relato institucional.

Con estas coordenadas veremos a continuación cómo abordar metodológicamente los relatos de experiencia traumática que fueron enunciados institucionalmente. El recorrido metodológico que trazamos a continuación tratará de dar cuenta del mismo sistema que habilitó (y descartó) ciertos tipos de codificaciones de la experiencia, que fuera diagnosticada por las terapeutas como traumática. 
"Todas las penas pueden soportarse si las ponemos en una historia o contamos una historia sobre ellas"

-Isak Dinesen-

V. Lo metodológico. El oficio sigue siendo buscar:

¿Qué relación tiene la experiencia de vida del/a investigador/a con su tema de investigación? ¿Es un obstáculo epistemológico-metodológico esa cercanía con el objeto, con los sujetos? ¿Existe la investigación socialmente comprometida, la investigación "militante"24? ¿Qué relaciones se tejen entre la investigadora y los sujetos investigados? ¿Qué hacer con las emociones que se desprenden de la práctica de campo? ¿Cuál es nuestro compromiso con el otro? ¿Puede una posicionarse en campo, romper con esa supuesta "objetividad" en un plano etnográfico y epistémico? ¿Cómo convertir un problema social en un problema teórico- epistemológico?

A continuación presentamos los materiales de estudio con los que hicimos este recorte y de ese recorte surgió el análisis del Capítulo 3. Pedimos al lector y lectoras de estas líneas que las lea en clave de mapeo y travesía, lejos de presentar un capítulo sencillo, la travesía fue trunca y la reflexión confusa por momentos. Lo metodológico fue la luz para ordenar estos mapas tramposos del quehacer científico.

\footnotetext{
${ }^{24}$ Esta idea de investigación militante la utilizó el Dr. Mario Pecheny en un panel de discusión sobre política y metodología en el Instituto de Investigaciones Gino Germani- UBA.
} 


\section{Objetivos}

General:

1. Analizar y comparar distintos modos de enunciar en distintas escenas/situaciones comunicativas de dos organizaciones con el objetivo de reconocer, describir y caracterizar los modos y formas de narrar situaciones traumáticas vividas durante la infancia.

Específicos:

2 Caracterizar los modos de enunciar los relatos elaborados en cada escena/situación comunicativa.

3. Analizar las estrategias discursivas que utilizan los sujetos para vivir la experiencia narrativa del abuso.

4. Analizar los usos que hace cada sujeto interviniente en cada escena comunicativa de esos testimonios.

\section{¿Quién dibuja los mapas?}

O de las condiciones de producción del problema de investigación

Preguntarnos por las condiciones de enunciación o por la situación comunicativa que atraviesa/parte/delimita las preguntas de investigación -que darán forma al problema de investigación- es preguntarse por el contexto del investigador. Esto último trataré de sostenerlo.

Haber y Figari retoman los apuntes de Haraway para localizar la posición desde donde se enuncian los análisis, si bien la identidad -autoidentidad- (1999) no produce ciencia, el posicionamiento crítico sí... es la objetividad, transparentar quién habla, desde dónde, bajo qué perspectiva, con qué influencias. En términos comunicacionales, un lugar de enunciación (Voloshinov) social-discursivo y de sentido desde donde una habla, dónde se empieza a construir la difícil relación con el otro. 
Boaventura De Sousa Santos (2009), Irene Vasilachis de Gialdino (2006) y Alberto Leonardo Bialakowsky (2009), autores que sin hablar de conocimiento situado trabajan con varios de sus postulados, en especial, la crítica a la mirada hegemónica de las ciencias. Ellos señalan la importancia de contextualizar el conocimiento, de pensarlo como un proceso que implica prácticas no sólo metodológicas sino también éticopolíticas, de reconocer y considerar como iguales a los sujetos conocidos, a los sujetos de estudio. Seguimos con De Sousa Santos quién desarrolla cómo en el acompañamiento de nuestros problemas de investigación nos encontramos muchas veces con teorías y conceptos que no son los más indicados y eficaces para permitir abordarlos en profundidad. Así “(cada vez) resulta más claro que las teorías, los conceptos, las categorías que usamos en las ciencias sociales fueron elaborados y desarrollados entre mediados del siglo XIX y mediados del siglo XX en cuatro o cinco países: Francia, Alemania, Inglaterra, Estados Unidos e Italia” (De Sousa Santos, 2009, p. 137). Es así como importamos teorías y categorías sociales legitimadas en el campo científico (de otros países, de otras regiones, de otras realidades) incongruentes con nuestro contexto. Otro de los problemas que destaca es "que las ciencias sociales son monoculturales, es decir que por detrás de los conceptos está la cultura occidental, y resulta problemático aplicar estos conceptos a realidades no occidentales" (2009, p. 138). De allí la relevancia de los estudios poscoloniales en la actualidad.

En diálogo con esto, Bialakowsky propone el concepto de "coproducción investigativa": con el mismo hace referencia a la participación de los investigadores y los sujetos de estudio en la producción de conocimiento a través de un diálogo coproductivo. Lo que intenta a partir de esta propuesta es evitar los sesgos y las divisiones de las formas de conocimiento tradicionales que según el autor, limitan una comprensión más acabada. Por ello, debemos redefinir las formas de aproximación y abordaje de los sujetos de estudio, en las cuales es clave la "investigación e interrogación conjunta con actores coproductores de Conocimiento" (Bialakowsky, 2009, p. 185); es decir, que el sujeto de conocimiento participa del proceso investigativo.

En esta nueva forma de conocimiento no están exentas las tensiones, ni los "avances y retrocesos respecto de la utopía epistémica" (Ídem) que atraviesa todas las instancias de coproducción investigativa. Esas tensiones y obstáculos son afrontados con creatividad "lo cual implica un trabajo de reflexividad (Guber, 2004), de diálogo y 
exposición" (Bialakowsky, 2009, p. 187) entre los investigadores y los sujetos de estudio "en el proceso de constitución en coproductores de conocimiento y de conformación de una voluntad colectiva por conocer y comprender" (Ídem).

En la misma línea, Irene Vasilachis de Gialdino (2006) postula una "Epistemología del Sujeto Conocido" como "fundamento de la investigación cualitativa y encaminada a reconocer la comprensión cooperativa del conocimiento en ciencias sociales" (2006, p. 1). "Esta propuesta se centra en la práctica real, situada, basándose en un proceso interactivo en el que intervienen el investigador y los participantes" (ídem, p. 4), donde ambos interactúan, son transformados y se ven afectados; más aún cuando se indagan y rememoran experiencias ligadas al temor, la angustia, la violencia y el desamparo. El investigador como persona situada en un determinado contexto, "debe tener presente que sus valores, perspectivas, creencias, deseos, expectativas influyen en la percepción y en la construcción de la realidad que estudia, y que la experiencia vivida es también una experiencia corporeizada" (Vasilachis de Gialdino, 2006, p. 8), siendo él mismo una fuente de datos. Estas indicaciones forman parte de lo que la autora llama la "Epistemología del Sujeto Conocido", para diferenciarse de la "Epistemología del sujeto cognoscente". En el proceso de conocimiento que propone esta última, "el sujeto cognoscente queda como actor primordial, manteniendo la distancia necesaria como para asegurar la objetividad de su conocimiento, y suponiendo una diferencia que lo separa del sujeto conocido y que lo preserva de ser, él también, transformado durante dicho proceso." (Vasilachis de Gialdino, 2006, p. 17)

En cambio, la Epistemología del sujeto Conocido "viene a hablar allí donde la Epistemología del sujeto cognoscente calla, muta o limita, e intenta que la voz del sujeto conocido no desaparezca detrás de la del sujeto cognoscente, o sea tergiversada como consecuencia de la necesidad de traducirla de acuerdo con los códigos de las formas de conocer socialmente legitimadas" (Ídem). En este sentido, el sujeto conocido es una "parte activa en la construcción cooperativa del conocimiento y una presencia no oscurecida o negada, sino integralmente respetada en la transmisión de este.” (2006, p. 18) 
En el entramado de propuestas de estos autores destacamos la recuperación de la importancia de la interpretación en la investigación cualitativa, la (re)flexibilidad de sus métodos y análisis como la sensibilidad en cuanto al contexto en que los datos son "coproducidos" (Bialakowsky, 2009), siempre en forma "conjunta" con un otro que es parte activa en la construcción de conocimiento (Vasilachis de Gialdino, 2006).

¿Por qué producir conocimiento en el cruce de estas dos perspectivas? Porque permite el desarrollo de un conocimiento situado, porque permite considerar los distintos aportes de todas las disciplinas que intervienen en situaciones como éstas y sobre todo- porque trabaja con las coordenadas del lugar de enunciación de las preguntas de investigación. Vemos como desde la comunicación podemos dialogar con otros cruces teóricos y a la luz de esos diálogos ver ¿nuevos problemas? O nuevas preguntas quizás. Lo cierto es que con una sola mirada no pudimos darle cuerpo a aquello que se manifestaba constantemente y no sabíamos que era, otra vez nuestra obstinación en ciencias por nombrarlo todo. Aún así decidimos dejar y respetar los huecos no sin antes señalarlos y en este señalar tuvimos que cruzar disciplinas.

\section{El cuerpo al relato}

Fue a fines del año 2013 con la incorporación del grupo de pares al trabajo de campo que el eje de la tesis cambió. Allí, cara a cara con los relatos, poniendo el cuerpo a sus tristezas (y a las mías) empezaron las preguntas acerca de la preparación emocional y corporal del investigador entre (medio) de otras más: ¿Con qué derecho escucho sus secretos más íntimos? ¿A nombre de quién y a cambio de qué? No tenía un secreto para compartir, una experiencia compartible que sería el "intercambio" más lógico en organizaciones como éstas. Pensaba que la preparación que (me) faltaba era teórica, metodológica quizás, pero antes había otra urgencia que tenía que ver, más bien, con un plano experiencial: el cuerpo no estaba preparado para ponerse frente a tanto dolor ajeno, a tanta vergüenza, intimidad, repugnancia. Había algo de lo vivencial que me faltaba. 
Como mencionamos, Carlos Figari hace su propuesta metodológica en base al concepto de conocimiento situado: describir, analizar, interpretar a partir de la relación entre el investigador y el otro como sujeto-sujeto, en lugar de la "falaz" relación sujetoobjeto, planteo propio de la investigación en las ciencias. La propuesta de Figari para el trabajo intelectual es una instancia que supera la supuesta objetividad que se pretende desde las ciencias sociales, la relación cuerpo-cuerpo -va a decir- supone la construcción de una relación afectiva con el otro, de comprensión mutua. Esto significó para mi trabajo tener muy presente mis miedos, mis desventajas y por supuesto mis prejuicios, esa premisa que reza que todo investigador debe estar desprovisto de prejuicios a la hora de entrar a campo la cambiamos: tuvimos muy presente todas las contradicciones propias de una mujer joven que recién empiezan a indagar. La ruptura fue más fuerte, el extrañamiento, la novedad. Y es a esto que refiere Figari: pensarnos en función al otro, ese otro que también es una en ese momento.

Recordemos que la primera parte de este trabajo de campo fue en una ONG con relatos mediados tecnológicamente... bien distinto es poner el cuerpo a los relatos que estar "protegida" detrás de un espejo falso. De pronto, las tradicionales "técnicas de recolección de datos", no me bastaron para registrar aquellos días.

“Hablar de observación participante sería dar cuenta de nuestra disposición general, pero no de las actividades concretas que llevamos a cabo en el campo; hablar de 'entrevista en profundidad' supondría evocar una situación que pocas veces se nos planteó con tanta nitidez y delimitación; y referirnos a información y a informantes nos retrotraería a una objetivación con la que nos vinculamos que no estaríamos dispuestas a admitir porque no da cuenta de qué sentimos y cómo vivimos nuestros trabajo de campo con otras personas." (Guber, 2015, p. 15)

Tal como lo plantea Guber, necesitaba registrar, plasmar, codificar los distintos términos en que entablamos relaciones con nuestros interlocutores, recuperar esos días en que todo era nuevo, disruptivo, movedizo. Necesité herramientas, técnicas y habilidades que me permitiesen recuperar las lógicas que empezaba a conocer a partir del trabajo de campo etnográfico, entendido como relación social y como articulador de situaciones de interacción (Guber 2014). 
Pero estos planteos vendrían después. Por aquellos meses con el conocimiento de que existían grupos de pares sobrevivientes de abuso sexual, como ellos mismos se denominan, mi panorama y problema cambió por completo. Fue en esta instancia que el problema y la urgencia de reflexionar sobre la sensación emocional y corporal que estaba sufriendo en ese momento (y que volvía con más frecuencia a medida que pasaban los días) al escuchar, no la podía evadir. Una reflexividad narcisista, dirá Rosana Guber, una reflexividad que habilita a la pregunta por la figura del investigador. Con sus peligrosos límites y concesiones, esta mirada vino a ordenar bastante mis notas y diario de campo, fue el único pasillo que encontré con la suficiente luz para acomodar tanta idea apiñada. Y es que los vericuetos del dolor, del recuerdo tienen la capacidad de perderte en los relatos. Fue una decisión metodológica poner el cuerpo a sus historias, sentir sus tramas para luego reflexionar a partir/sobre ellas. Esta decisión, por supuesto, trajo no pocas encrucijadas éticas-filosóficas-políticas: ellos/as también demandaban un secreto a cambio, un intercambio legítimo, secreto por secreto.

La asistencia a este grupo de pares buscó correr esos límites, ir un poco más allá para preguntarnos, ¿hasta dónde el cuerpo del investigador se presta/soporta/aguanta estas tristezas ajenas? ¿Es posible la producción de conocimiento en estos "peligrosos" límites emocionales y físicos de los sujetos que intervienen en una investigación y, por qué no, del propio investigador?

He de aquí hacer un paréntesis y una comparación que prometo servirá para sostener lo que proponemos. En el 2008 me incorporé a un equipo de investigación y extensión en la Universidad Nacional de Misiones ${ }^{25}$. Los temas que abarcamos (actualmente sigo participando en dicho equipo) siempre rodean los mismos tópicos: violencia de género, prostitución, trata, incesto y la salud sexual y (no) reproductiva en una población mayoritariamente de mujeres adultas ${ }^{26}$. He de confesar que mi corta

\footnotetext{
${ }^{25}$ En ese entonces trabajamos en el Hospital Público Ramón Madariaga, en el sector de Maternidad, Planificación Familiar. Hacíamos Reuniones en la Sala de Espera con una fuerte impronta de talleres de salud sexual y reproductiva, entrábamos a las 6 de la mañana mientras las mujeres esperaban a ser atendidas por el personal médico (los turnos se daban a partir de las $5 \mathrm{am}$.). Utilizábamos esos "tiempos muertos" en los que la mujer necesariamente debía estar sentada esperando al médico (cerca de las 7 u 8 llegaba el médico), tomando mate, charlando, preguntando pero sobre todo escuchando. El tema era bien amplio, suficiente para hablar de otras cuestiones como la violencia. Si era necesaria alguna explicación teníamos láminas en tamaño real y otros insumos como métodos anticonceptivos (MACs) y folletería confeccionada por el mismo equipo.

${ }^{26}$ Luego de esta experiencia trabajamos en tres barrios periféricos más de la ciudad de Posadas (Sta. Cecilia, Yacyretá y San Jorge) en centros de salud y con un grupo de mujeres promotoras en contra de las
} 
experiencia en escuchar relatos duros, pesados, espesos, dolorosos viene del 2008 ya pero hay grandes variables con el trabajo que venimos realizando ahora para esta investigación. Quizás la soledad con que encaramos esta nueva travesía (no es lo mismo contar con un equipo de trabajo/contención que encarar estos relatos una sola), la palabra tomada por el niño o niña (el relato y el dolor cambia sustancialmente si lo cuenta una niña o niño que un adulto), las características de los delitos sexuales tienen algo (o todo) de indecible, inexplicable (para quien escucha y para quien cuenta), tiene todo de secreto y de terror, es algo que no puede ser dicho tan fácilmente. Con toda la atención puesta ahí el cuerpo se prepara para escuchar algo terrible...y en la soledad detrás del espejo falso de la cámara o con un grupo de pares, en la eterna encrucijada ética y profesional de abordar con mucho respeto y sensibilidad la tarea de escuchar y darles un tratamiento riguroso, científico y responsable a estos relatos. Nos queda como pregunta si el abordaje de este tipo de investigaciones no debiera realizarse siempre bajo la órbita de un equipo de especialistas por la ruptura y el daño que recibe el investigador al exponerse a problemáticas como éstas. Quizás para empezar a poner la mirada en la seguridad de ese investigador que por supuesto no es comparable al dolor de las víctimas, pero tradicionalmente es invisivilizado en estas tramas científicas. ¿Qué implica poner el cuerpo a tanto dolor sólo a los fines científicos?

violencias (PROGEN), su rol principal es asesorar y rescatar a toda persona que sufre o ha sufrido algún tipo de maltrato en su barrio y las inmediaciones. Las mismas son mujeres que han sufrido y sobrevivieron a sus propias historias de vida y hoy perciben una pequeña remuneración de la Municipalidad de Posadas por el trabajo que realizan en barrios de la ciudad de Posadas. Nuestro equipo ofrece capacitaciones en distintas temáticas referidas a la salud sexual y (no) reproductiva mediante talleres que realizamos con las mismas. 
VI. Crónicas para no perderse

Estas líneas, que rozan lo literario, fueron escritas con la intención de transportar al lector a mi campo. Queremos compartir -con la mayor precisión posible- el lugar donde trabajamos los últimos años y del cual surgió este trabajo.

\section{La cámara secreta}

A medida que avanzaba el tren -lento, melancólico- me preguntaba si todos los días tendría que hacer el mismo recorrido de una hora y cuarenta y cinco minutos para llegar. Los vagones estaban al mango, como dicen acá, mucho frío (Buenos Aires es impiadosa en el mes de Julio) y en cada una de las estaciones seguía subiendo más gente. A los empujones, desafiando los límites del mismo espacio. ¡Nos llevan como vacas! Gritó uno en el fondo. Me pareció una imagen graciosa: éramos el ganado que transportan a la zona oeste del Gran Buenos Aires para que trabaje. 20 minutos, 30 minutos, 45 minutos: Floresta, Liniers, Morón, Castelar, Ituzaingó, Padua. Una hora después, llegamos. Vengo de una provincia norteña donde todo nos queda más o menos cerca y a cualquier lugar no tardas mucho en llegar. Viajar una hora y cuarenta y cinco minutos, en tres medios de transporte distintos para ir a trabajar me parecía una cosa sacada de los pelos. No lo podía creer.

La ONG es así. La primera vez que llegué, la primera vez que pisé la sala de espera del lugar senti el primer escalofrío. Alejada del centro del centro del país, esta organización está al costado de las vías del tren Sarmiento, zona oeste de la provincia de Buenos Aires. Alli donde el paisaje cambia abruptamente de la soberbia capital federal, es la zona estigmatizada como "peligrosa”, narco, y mafiosa hasta por los mismos bonaerenses. De la estación de trenes tenés seis cuadras hasta la institución, es una casona gigante, vieja, fuerte y hermosa, cofre de secretos, de angustias pero de alivios también. Hacía muy poco que había oído hablar sobre esta ONG que se especializa en el tratamiento y asistencia de problemas referidos a la violencia sexual, explotación, drogadicción, anorexia, bulimia...entre otros. Todavía no sabía bien cómo iba a encarar mi trabajo sobre abuso sexual hacia niños y niñas, en ese momento solo quería explorar algunos contextos donde la problemática se venía trabajando desde 
otros frentes. Poco tiempo después, cuando pude dimensionar el trabajo que realizan a diario estas terapeutas, me seguía preguntando por su apertura y calidez al integrarme a su equipo de trabajo: una comunicóloga, norteña, becada que no era terapeuta ni trabajadora social pero con ganas de trabajar en el problema del abuso sexual.

Seguimos. Ese día nunca imaginé lo que me iba a encontrar, recuerdo al lector que hacia tan solo tres dias que me había mudado a la capital. Era mi primera experiencia hasta de viajar en tren. El término "perdida” me quedaba chico. Pero allí estaba...y tenía que entrar en algún momento: desde la coordinación me estaban esperando.

Toco timbre. Espero. El nerviosismo hacía de las suyas: mis manos eran agua y el calor me subía a las mejillas. Un timbre como respuesta me indicaba que la puerta estaba habilitada para empujarse. Entré. La coordinación se encuentra en una pequeña oficina y se accede a través de la sala de espera, es decir, para entrar a la oficina hay que atravesar la sala donde aguardan las personas hasta ser atendidas por alguna de las profesionales. Recuerdo que la primera vez que entré me sorprendí de la cantidad de niños y niñas que había, iparecía un jardín maternal! En el ala derecha de la casona se encuentran los consultorios y las habitaciones ambientadas con la cámara gesell para las evaluaciones y del lado contrario las oficinas donde aguardan las terapeutas, hacen las reuniones, toman mate o pasan el rato. “¿Rosaura Barrios? Ya podés pasar”, entro a la oficina.

La institución cuenta con una coordinación que se encarga prácticamente de todo. Recordemos que esta institución no solo hace tratamientos psicológicos sino evaluación, entrenamiento de personal, formación en temas referidos a violencia y abuso para profesionales de distintas ramas. Asisten a víctimas de abuso y explotación sexual, anorexia, bulimia, drogadicción, violencia....además de las actividades ya citadas. La dirección es la encargada de las gestiones institucionales, formación en materia de abuso sexual en distintos espacios a lo largo y ancho del país y en el extranjero también. Allá por 1997 dieron vida a la ONG como un servicio gratuito a su comunidad en temas referentes a la violencia y ya para 1999 se constituyen como Asociación trabajando con jóvenes pasantes que despliegan su accionar ad honorem.

Pero seguimos. Nos reunimos para coordinar actividades juntas, vine con la idea de investigar los modos de narrar el dolor... una idea muy vaga pero idea en fin, y esa reunión era clave para saber si podía desarrollarla alli. Tuve suerte. La ONG había abierto la convocatoria para seleccionar profesionales de distintas disciplinas para 
formar una mesa de estudios especializada en abuso sexual infantil. La selección de profesionales no es un dato menor, la dirección debe asegurarse no dejar entrar a personas con intenciones o valores distintos a los que convocan. Así fue que me vi participando de un grupo de profesionales -entre educadores, abogadas, psicólogas, trabajadoras sociales y quien escribe- discutiendo sobre los obstáculos de la interdisciplina para abordar problemas sociales como el abuso, las intervenciones en cada una de las escenas y "actividades de concientización."

Nunca faltó el mate lavado y alguna que otra galletita que traían las chicas durante las reuniones. La casona donde funciona la ONG es fría, grande, eso hace que el calor se escape por los pasillos ruidosos. La pequeña cocina es el lugar más frío de la casona pero yerba y té nunca faltó. Una cocinita destartalada nos hacía el favor junto con una pava recontra vieja. Pero no me puedo quejar, ese lugar tenía mucho de misterio que me gustaba. Solo funcionaba una de las dos canillas que había y así nos arreglábamos, una estufita que echaba todo el calor que podía y el rechinar de las puertas siempre nos recordaba que hacía falta reparar urgentemente esa casa.

Teníamos una mesa circular y allí nos reuníamos durante poco más de dos horas un día a la semana a discutir, armar documentos, participar de congresos y ayudar en los casos que en ese momento estaban siendo tratados. Eran horas pico, donde la actividad de los consultorios estaba a pleno, las terapeutas iban y venían, completaban planillas durante las reuniones, salían de cámara (gesell) o entraban a atender. El teléfono sonaba sin cesar, otro caso, va a la lista de espera, tal juez, tal abogado, la fiscalía rechazó el pedido de pruebas....muchísimos discursos cruzados a la vez y nosotras ahí, reunidas para trabajar en una mesa de estudios. Hubo encuentros en que no hacía falta decir mucho, tan solo hablábamos de los casos, porque eran eso: casos. El dolor las excedía a veces y necesitaron de ese espacio para canalizar la angustia, para exteriorizar la impotencia. Recuerdo claramente a Marina, con los ojos llorosos llegó un día. Hacía casi un mes que estaba asistiendo a las reuniones. Acababa de salir de una evaluación en cámara gesell con una niña de 5 años. No puedo más, dijo casi sin voz, la coordinadora solo atinó a decir que se calme y se siente. "Es un hijo de puta, un hijo de re mil puta. Fue el papá.", 
Y con este zumbar en mis oídos y el silencio espectral en la sala no pude sacar la vista de Marina... siempre me llamó la atención eso: estas mujeres nunca se acostumbraron al horror, seguían con la capacidad intacta del asombro a pesar de los años trabajando en lo mismo. Fue el primer silencio que recuerdo y al recordarlo se me eriza la piel de nuevo, fue el primero de muchos más, es como si el silencio fuera la única respuesta que podemos dar ante el terror. Ese primer silencio fue eso: el primero de muchos más, de muchos baches, callejones sin salida, fue el primero de otros que vendrían más duros, más intensos y más dolorosos también.

Cuando salí a la calle, ya de noche con el frío pisándome los talones, fue que entendí que debía escribir para no perderme en los vericuetos de la incertidumbre y la impotencia. Cuando trazar mapas fue la única herramienta que encontré en ese momento para no perderme fue cuando entendi que ese silencio se extendería en mi andar por arenas científicas, silencios no solo de parte mía -de una incomprensión total- sino también de quien pretende hablar, de quien pretende contar. Por eso estas crónicas; para buscar aquello que no se dice, pero también para encontrarme entre tantos pasillos fríos y preguntas sin respuestas. Es la única herramienta que cuento (y la que puedo utilizar) para transportar a mis lectores a esas salitas frías y dolorosas, a ese andar por el trajín del campo científico. Son crónicas de un silencio que irrumpió y lo fue todo por un momento. Por un momento. Pero eso yo no lo sabía por aquellos tiempos. Fueron muchos libros y experiencias después. La vuelta en el tren siempre es dura. Ya es de noche, el frío aprieta más las costillas y la ansiedad de los pensamientos me obligan a volcar en papel lo escuchado. Mi diario de campo empezó así, una simple línea: ¿cómo? Pero la academia esto no me lo iba a perdonar, así que tuve que mejorar con el tiempo. Ahora dicen algo así como: las características de los relatos en tal o cual escena comunicativa; la experiencia narrativa del abuso y otras construcciones bien justificadas....pero esto solo con el tiempo ocurrió, en ese momento, en esa primera vuelta solo tenía hambre, frio y demasiadas preguntas en la cabeza. Esto recién empezaba y se plasmó por primera vez en unas pocas líneas de vuelta en el Sarmiento. 
Un Grupo para contar el dolor

No fue dificil llegar a las reuniones del grupo que se reunía una vez a la semana, seguir el día con normalidad luego de las reuniones fue lo complicado. Y es que los relatos en primera persona y de frente siempre se te pegan al cuerpo y al alma, nunca salís igual después de su escucha. Lo más terrible de escuchar no es el hecho en sí del abuso sino darte cuenta, con horror, de la insensibilidad, el descreimiento, el rechazo, el abandono de quienes debieran ser los guardianes de aquellos que fueron niños y niñas. Lo más terrible fue tener frente a mí un espejo de la condición humana más cruel e insensible y si bien, en principio, no queda mucho margen para la esperanza, no es el mensaje que buscan dar con cada intervención.

El grupo se reúne una vez por semana mediante mates y galletitas que cada uno/a lleva, a veces el lugar se presta a una mesa más o menos redonda, otras solo el piso y un par de sillas nos acompañaban. La ronda siempre contó con nuevos integrantes en cada encuentro lo cual obligó a cada miembro presentarse casi todas las semanas y volver a contar "su historia." En este contar no sólo es un contar sino un compartir y no sólo fueron historias sino lágrimas, habitual en integrantes nuevos, los más antiguos solían tener respuestas para todo, siempre tenían la situación más o menos bajo control.

En dos horas de encuentro no solo hablaban de sus historias sino también de sus casos, cómo estaba la causa, que sucedió últimamente, la familia. Eran temas recurrentes ya que la gran mayoría no denunció lo que le hicieron pero sí tuvieron oportunidad de contarlo en sus familias, muy a mi pesar debo confesar que esa gran mayoría no recibió ni comprensión ni protección en su momento. Todavía recuerdo las palabras de la directora de la ONG repitiendo una y otra vez que la recuperación del chico es proporcional al acompañamiento familiar. Lo más duro es ver las secuelas que deja el abuso sexual en una persona adulta, en dos años pude ver a sobrevivientes (y a los que no sobrevivieron) del incesto, pude hablar y llorar con mujeres que no han podido superar bajo ningún término semejante herida y se sumergieron en distintas depresiones, buscando dormir con ansiolíticos ese dolor que nunca descansa. Recuerdo un encuentro de mucho sol y frío en Capital, un nuevo integrante los visitaba con ganas de hablar y ser escuchado quizás por primera vez. Venía de Uruguay y estaba en situación de calle viviendo en Plaza Flores, cuál fue nuestra sorpresa al escuchar de su propia boca una experiencia de abuso sexual cometida hacia él cuando era un niño en 
la escuela católica a la que asistía en Montevideo. De todas las desesperanzas y penurias que atravesó en su dura vida eligió ese episodio como punto de partida, como un quiebre para contar, esa era la pena más importante para él y fue a raíz de ella que decidió acercarse para compartirla. Luego de ese día no volvió más al grupo, quizás ya había cumplido su objetivo, nunca supimos nada más de él,, pero lo que quedo flotando ese día en mis notas de campo fue la importancia o el lugar que ocupa una violación en los registros experienciales de cada uno/a, el uruguayo no se quejó de su vida ni de su situación durísima y sin muchas expectativas de vida, no contó cómo llegó al lugar donde está, ni siquiera se quejó de esta sociedad tan absurda y cruel que empuja hasta convertirnos en nada, el uruguayo contó como un cura abusó de él siendo un niño y cómo tuvo que escaparse de su casa porque no soportó lo que se venía.

Miércoles tras miércoles durante dos años fue así, en varias oportunidades los acompañé a sus intervenciones en la vía pública o en jornadas y congresos a los que fueron invitados, siempre como colaboradora. El discurso fue tomando fuerza y se fue convirtiendo en otra cosa. Cada vez que Omar se paraba a hablar algo sucedía en la sala, siempre hablaba de solidaridad, compañerismo, esperanza, lucha, militancia. Militancia. Y esa palabrilla circuló por cada miembro del grupo, en algunos con más fuerzas que en otros, pero fue tomando cuerpo, espíritu, tanto que el grupo tuvo personalidad y carácter. Así y con el tiempo, ayudó a otros grupos a que se formaran asesorando a sus miembros o tan solo compartiendo la experiencia durante las reuniones.

Lo cierto es que mis cuadernos desbordaron de notas de campo por aquellos días, fueron desplazamientos nuevos con los que me encontré, muchas personas amables, comprensivas, otras muy enojadas, lastimadas... en el transitar de dos años por los pasillos de la vieja casona donde se realizaban los encuentros aprendí a escuchar el silbido del viento frío que solía hacerse presente muy de seguido cada miércoles. Y es que ante la ausencia de palabras es el silencio quién aparece con fuerza y todo lo abarca. Pesado, obsceno, generoso de sus formas y dinámicas. Él sería mi brújula para empezar a hilar los hilos de esta gran red analítica. 
VII. Herramientas y categorías (El campo y sus vericuetos):

¿Cómo trabajar con los materiales de análisis teniendo en cuenta sus características? ¿Qué tratamiento merecen los relatos de experiencia traumática? ¿Cómo pensar un campo fuertemente intervenido por discursos de corte legal, psicológico, del campo de la criminalística y el trabajo social? ¿Qué herramientas tomar de cada disciplina para construir el mapeo del trabajo de campo? ¿Cómo se escriben estas notas teniendo en cuenta todos los cuidados que merece el trato con población vulnerada?

Este apartado problematiza cuestiones éticas-metodológicas que nos explotaron en el campo. Y es que las decisiones metodológicas tomadas en relación a experiencias que denigran y atentan contra la integridad humana deben ser cruzadas fuertemente con una ética investigativa rigurosa. Son planteos teóricos y metodológicos en torno a la escucha, la observación y el silencio, que componen un mapeo posible para el estudio de experiencias traumáticas que tienen que ver con el abuso sexual y la violación. Es una puesta en tensión de la posición política de poder que ocupa el investigador en estas tramas, el uso de algunas herramientas de recolección de datos y la necesidad de entablar diálogos y puentes con otras disciplinas con trayectoria en este tipo de estudios. En la instancia de exploración del campo, allá por junio del 2012, decido entrevistarme con las autoridades de la organización donde iba a quedarme los próximos dos años y a conocer al grupo de adultos con el que iba a trabajar. Esto responde a dos cuestiones: por un lado, iniciar las formalidades que la entrada a campo en una institución significa; y por otro, buscar empalmar los tiempos y dinámicas de las organizaciones con las del trabajo de campo. Este último punto será crucial para el desarrollo de la tesis, registrar los relatos del equipo de salud trabajando, la dinámica cotidiana de la organización, los relatos dichos grupalmente y, sobre todo, la confianza de la coordinación para permitirnos el acceso a sus instalaciones y escuchar a sus miembros. Este acceso del que hablamos no se refiere solo al ingreso físico, sino a un ingreso más bien simbólico, dicho así parece una obviedad pero con el tiempo caímos en cuenta de que esta confianza no es dato menor a la hora compartir experiencias de este tipo. Fueron necesarios muchos meses de diálogo previo antes de exponerme a estos testimonios e historias de vida, el respeto y la espera por los tiempos del/a otro/a fue una decisión metodológica respondiendo a principios éticos y de respeto más que a intereses académicos-investigativos. 
Precisamente por esta decisión es que no utilizamos como herramienta de recolección de datos la entrevista en profundidad, convencidas de que no cuento con insumos personales para afrontar el caudal de relatos de una víctima "sobreviviente" de abuso sexual, ni la formación para contener en caso de que el recuerdo de estas experiencias desate sentimientos de tristeza o angustia.

“[...] el trabajo de campo no consiste en la aplicación de métodos claramente definidos desde la academia con sus aulas y oficinas. Consiste en un reconocimiento más amplio de los términos en que entablamos relaciones con nuestros interlocutores y que nos permiten conocerlos recuperando sus perspectivas acerca de las cuestiones que les preocupan, les interesan, los motivan, los enorgullecen y los avergüenza." (Guber, 2014, p. 15)

Siguiendo en la línea de Rosana Guber, el trabajo de campo y su intervención fue pensado específicamente para este objeto de estudio, buscamos las herramientas más adecuadas para empezar a pensar el problema sin ser intrusivas, apuradas $\mathrm{o}$ violentas...en términos de autoridad etnográfica y esta supuesta impunidad que tenemos desde las ciencias para realizar cualquier tipo de preguntas que competan a nuestro trabajo.

\section{Un campo fuertemente intervenido \\ La (Inter)Disciplina}

Este trabajo de campo de fuerte corte etnográfico -entendida como una perspectiva de conocimiento que aspira a comprender los fenómenos sociales desde el punto de vista de sus protagonistas- es pensado como relación social y como articulación de las situaciones de interacción (Guber, 2014). Como escenario "donde el investigador pone en interlocución sus categorías teóricas y prácticas de académico y de ciudadano con las categorías y prácticas nativas" (Ídem, 2013, p.59), para pensar al mismo nos servimos de otras disciplinas para confeccionar su protocolo de acceso e intervención. Por un lado, de la psicología tomamos el manejo del anonimato y la confidencialidad, que si bien son reflexiones que involucran a nuestra disciplina, el 
manejo que realizan desde la misma es distinto, adecuado, conocido y propio de este contexto. De la criminalística y el derecho el tratamiento y comprensión de documentos que refieren a causas legales en curso, como la ONG se maneja siempre con denuncias de por medio y en el grupo de pares los comentarios más frecuentes fueron sobre el estado de las causas, tuvimos que aprender de ese registro y su manejo en estos contextos. De la antropología la categoría de reflexividad ordenó las notas de campo y su posterior escritura:

"El concepto de reflexividad que se evoca en la etnometodología desarrollada por Harold Garfinkel (1967) e inspirado en la fenomenología propuesta por Alfred Schütz, fue central para pensar el trabajo de campo y la etnografia. Se trata del papel constitutivo que ejercemos en cualquier ambiente al actuar y enunciar. (...) En este intersticio, que se crea y recrea en la relación, trabaja el antropólogo. No sólo reconociendo los procedimientos reflexivos de los nativos sino también los procedimientos propios, porque es en esa relación donde se produce sentido y se hace posible la comprensión en términos antropológicos, una comprensión susceptible de ser relatada que involucra siempre formas variables de invención y creatividad. Considerando el papel constitutivo de la reflexividad es posible reconocer las limitaciones que resultan al defender la idea de que existe una 'realidad' separada del 'sujeto' cognoscente, y de que ambos interferirán mutuamente." (Renoldi, 2014, p. 131)

La literatura, el cine y la fotografía contribuyeron a la comprensión de estos relatos, como veremos en el análisis, no había palabras para contar ni contábamos con imágenes para re-presentar(nos) esos relatos. Tuvimos que aprender a trabajar con los silencios y el secreto. Este último como categoría y práctica fue un nudo troncal en el trabajo que obligó a virar el mástil en su momento hacia otras estrategias metodológicas que lo contemplen en su complejidad. En cuanto a esto, “[...] más que preguntarnos si lo que se nos ha dicho es cierto o no lo es, conviene averiguar qué significa y cuáles son las implicancias posibles de lo que se dice (e inferir lo que se calla)." (Guber, 2001, p. 243) 
Como veremos líneas adelante, el manejo y análisis del secreto no tiene que ver tanto con lo que dicen sino con lo que hacen de ese secreto, el uso que dan. "Aún pudiendo pensar en todo lo que significa para el etnógrafo entender el secreto en su dimensión sociológica, no deja de ser un conflicto para su trabajo saber cómo proceder con informaciones que le son contadas de forma confidencial por quienes saben que a él le interesa conocer y comprender sus vidas y sus cotidianos." (Renoldi, 2014, p. 134)

En este sentido se produce un doble movimiento: el investigador elige la información y recorta los datos y, a su vez, el campo elige qué mostrarle al investigador al punto que éste no sabe qué es o qué no es un dato a priori (Guber, 2013). La vigilancia sobre qué registrar y qué no registrar estuvo presente durante todo el trabajo, fueron estas disciplinas las que nos ayudaron a descifrar qué y cómo registrar en el diario de campo sus experiencias en relación al abuso. Con respecto a este punto y a la incorporación de la reflexividad para pensar todo el proceso de investigación “(...) se trata de partir de la base de que no describimos 'realidades', sino que apenas podemos describir aquello que constituimos de manera activa en una red de relaciones heteromorfa y heterogénea que no tiene límites dados en sí, y que se constituye en la experiencia” (Renoldi, 2014, p. 131).

\section{¿Cómo acceder a ese campo?}

Mi directora -seleccionada por CONICET- una vez recibió un mail de esta ONG con invitación a un Congreso del cual eran organizadores. Me pasa el contacto y escribo a la coordinación para iniciar los encuentros; a principios del 2012 y aún en Misiones todavía no tenía vistas de dónde realizaría mi investigación. Tuve suerte, estaban seleccionando profesionales de distintas disciplinas para conformar la mesa de estudios sobre abuso sexual infantil. Fue esta mesa la que me permitió entrar "al mundo" de esta problemática, todos los libros citados, todas las profesionales, los casos que más se mencionaron mediáticamente, los grupos de pares que se desprendieron, todo surgió de esta ONG. El prestigio y los años que llevaban en estas aguas contribuyeron en gran medida a la certeza de mis movimientos tanto en capital como en provincia de Buenos Aires, ser parte de esta mesa de estudios significó contar con gran parte del material aquí presentado. 
Los tiempos y dinámicas institucionales/organizacionales de investigación que buscamos empalmar se tradujeron en acciones concretas para acceder (y permanecer) en campo: la participación como miembro activa en la mesa de estudios interdisciplinares en abuso sexual infantil de la ONG descripta en el primer capítulo; y participante (como oyente) del grupo de pares que se reunía una vez por semana en Capital. Este último punto no es un dato menor, fue una decisión metodológica intervenir sólo de oyente en estas reuniones; tanto en una como en otra organización debido a su historia y características en cuanto al tratamiento de experiencias relacionadas con el abuso sexual infantil y sus tiempos escogidos para contar, escuchar, asimilar.

La intención de poner por encima de todo el respeto por las personas que intervinieron en la investigación se tradujo en utilizar los tiempos de la organización para escuchar los relatos y seguir a sus ritmos. Sin apurar con entrevistas, preguntas o reuniones, me adapté a los tiempos que ellos/as proponían y a las actividades que tenían como grupo. Con el tiempo esto trajo algunos problemas, en el grupo de pares a medida que pasaban los meses y a pesar de mis justificaciones investigativas los miembros con los que logré un acercamiento más cercano, por fuera de la investigación en sí, exigían (legítimamente) que "cuente mi historia." Este contar mi historia, por supuesto se refiere a mi experiencia o relación con el abuso sexual. En términos de Renoldi, "reciprocidad": “(...) uno recibe la confianza del nativo que le permite conocer sus formas de vida, y en compensación deberá ofrecer algo que equivalga, en términos de ventajas o beneficios para él.” (Renoldi, 2014, p. 132)

A nadie le parece casual o cotidiano que una investigadora se acerque con intenciones de saber sobre la problemática, como ellos/as mismos dicen, a nadie le interesa estos temas. Fue en esos tiempos en que cerré el campo. Cuando el grupo pautó nuevas reglas y formas de relacionarse, nuevas dinámicas y actividades es que, en noviembre del 2014, decidimos cerrar. Una de estas nuevas formas de relacionarse, ser y estar tuvo que ver con no permitir más el acceso al grupo a quienes no fueran exclusivamente sobrevivientes de abuso sexual y/o se acerquen con intenciones de "militar" en las actividades del grupo o compartir experiencias de vida. Esta decisión la tomaron los miembros fundadores del grupo, una vez que fue tomada cerré mi trabajo. Pero he de decir que era algo previsible para mí que iba a suceder puesto que las insistencias, la necesidad (?) de conocer "mi historia", mi experiencia, secreto por secreto, se hacía cada vez más urgente a medida que pasaban los meses y la confianza. 
Ya no bastaba mi curiosidad (impune) de investigadora. El grupo demandaba conocer mi historia de vida. Como vimos en el apartado anterior, estas dinámicas son muy particulares, todos sus miembros/as se conocen y están al tanto de sus vidas privadas, las preguntas son particulares, dirigidas, precisas. Si bien todos/as tenían en claro mi función en el grupo, seguía siendo una desconocida y eso ya no podía ser concedido en la segunda parte fundacional del grupo.

En cuanto a la ONG, acostumbradas a investigar e intervenir en la problemática, no llamó demasiado la atención mi presencia en la vieja casona y adeás contaba con el aval de la directora y la coordinadora para investigar, visto bueno que me siguió abriendo puertas meses y hasta años después. Esto a colación de lo que menciona Guber, cuando exponemos nuestras notas de campo, nuestros registros de aquellos días exponemos no sólo nuestro trabajo "en crudo", sino nuestro mapeo de cómo nos movimos, que hicimos, como reaccionamos, qué pensamos.

"Más allá de discutir en términos teóricos con sus pares académicos acerca de lo que dice que ha hecho en su investigación, el investigador sabe que necesita ofrecer sus datos de campo a riesgo de perder credibilidad y sabe, también, que esos datos los obtuvo en formas bastante ateóricas (o preteóricas), intuitivas, inesperadas y hasta casuales. Más aún: sabe que el baño de teoría es un arreglo a posteriori, un dispositivo que comienza a operar después de haber llegado, haber visto, hablado y escuchado no todo pero sí lo suficiente.” (2013, pp. 40,41)

Este mapeo aquí expuesto parece ser bien primario, básico, casi del sentido y del accionar común pero he de decir que cada paso fue muy pensado, calculado y otros que fueron hechos por pura voluntad. Estos pasos o decisiones tomadas casi intuitivamente fueron escasos pero "acertados" algunos. Sin dudas enriquecedores no sólo en materia investigativa sino de reflexividad, la vigilancia epistemológica me pesaba con cada decisión, y es que el contexto todo el tiempo me interpelaba a que registre todo lo que allí estaba sucediendo. Lo peligroso y lo doloroso estaba allí pisándonos los talones. 


\section{Una metodología para el Dolor}

Con la particularidad de este campo: ajustado, limitado, lidiando (peleando a veces) con un discurso institucional hipercodificado como lo son las ONGs, cabe preguntarnos: ¿Cómo movernos dentro de estas simplificaciones, limitaciones, fronteras laborales? ¿Cómo articular los objetivos personales de investigación con los comunes que nuclean a las personas que trabajan en una ONG? ¿Cómo empalmar los intereses personales con los de la mesa? ¿Cuál es la metodología y herramientas más adecuadas para el tratamiento de estos datos?

Cuando el callejón se hizo más estrecho y las técnicas de recolección de datos tradicionales no me bastaban para registrar todo lo que ese campo estaba provocando(me), devolviendo(me), mostrando(me) se hizo necesario incorporar otras lecturas, otras formas de abordarlos. Todos los trabajos que ponen la mirada en conflictos bélicos (Colombia, Perú), últimas dictaduras cívico-militares, eclesiásticas (Argentina, Brasil, Paraguay) que abordan la experiencia traumática a través de testimonios escuchados en contextos institucionales por fuera de una investigación científica, fueron mis referencias en esta nueva etapa. Esto tenía que ver con reconocer otras formas de abordar relatos que tengan que ver con experiencia traumática en contextos institucionales que tienen por finalidad su escucha y sistematización. En este indagar otras formas de abordar, la metodología fue tomando fuerza y sentido y las herramientas fueron pensadas en función a qué queríamos sistematizar y recolectar.

\section{La Escucha y Observación}

"Hablar de observación participante sería dar cuenta de nuestra disposición general, pero no de las actividades concretas que llevamos a cabo en el campo; hablar de entrevistas en profundidad supondría evocar una situación que pocas veces se nos planteó con tanta nitidez y delimitación; y referirnos a información nos retrotraería a una objetivación con las que nos vinculamos que no estaríamos dispuestas a admitir porque no da cuenta de qué sentimos y cómo vivimos nuestros trabajo de campo con otras personas." (Guber, 2014, p. 15) 
La escucha y la observación se convirtieron en herramientas fundamentales de acercamiento y sistematización. Este adaptarme a los tiempos de las organizaciones se tradujo en estas herramientas sin registro de audio o escrito en el momento. La narración de experiencias de este tipo produce un quiebre en el lenguaje imposibilitando de que haya -efectivamente- relato. Todo es silencio, hueco, vacío. Situar las preguntas de un investigador en estos lugares significa imponer ritmos y formatos narrativos para el contar, por ende, rememorar, volver a vivir, supone intervenir en tiempos subjetivos de rememoración del horror y sufrimiento de la experiencia, busca gestionar lo indecible, de rellenar los huecos narrativos, de encontrar aquello inaprensible. No podía dejar (aun no) de ver la presencia de un investigador en es(t)as tramas como intrusiva, es así que buscamos la forma de investigar con una metodología ajustada a estos cuidados. "Cuando se habla sobre violaciones, se le da una gran importancia a los silencios. Qué hacer con estos silencios -cómo escucharlos, cómo interpretarlos, cómo determinar cuando son opresivos y cuando pueden constituir una forma de agencia- es un tema de gran preocupación y debate.” (Theidon, 2006, p. 71)

Aún así, esta propuesta nos abre otros interrogantes: ¿En qué medida las organizaciones que son facilitadoras de la enunciación de los relatos de estas víctimas permiten efectivamente la emisión de esta voz? ¿Qué géneros habilitan para moldear el sufrimiento y el dolor? ¿Puede narrarse el horror con éstos géneros disponibles para el contar? ¿En qué medida son compatibles éstos géneros disponibles con los que necesita "la justicia" para proceder a favor de las víctimas?

La escucha se realizó durante todo el período de campo tanto en el equipo de salud de la ONG como en el grupo de pares sobrevivientes. Con más posibilidades de intervenir en la mesa de estudios (ya que formaba parte de la misma) que con el grupo de pares, mi escucha se volvió sistemática: en la mesa de estudios podía registrar por escrito en el momento lo que estaba escuchando, pero en el grupo de pares el registro de campo debía hacerse después de terminada la reunión. Si bien el grupo (a través de la voz de varios de sus miembros más antiguos) me ofrecieron, en varias oportunidades, grabar las reuniones o hacer entrevistas personalizadas, me negué en todas las ocasiones a hacerlo. Convencida de que era suficiente esta puesta del cuerpo al relato y (todavía) desconfiando de mi capacidad de contener el caudal de relatos dolorosos que sabía iba a aparecer. Ambos grupos tenían dinámicas particulares que lograban calmar la angustia y opresión que pesaba en el ambiente, pero ese contener era grupal. 
Además, el contenido puntual de sus relatos no nos interesaban sino su enunciación y codificación en organizaciones como éstas. Ambas lógicas encontraron la forma de sostener esa pesadumbre que se siente cuando estos recuerdos aparecen, la escucha se agudiza, los sentidos se afilan y la piel se prepara para lo peor. Decidí (no antes de comprender estas lógicas) que la mejor manera de estudiar estos relatos era con una metodología pensada y amoldada a estas dinámicas.

Theidon, quien participó en las Comisiones por la Verdad y la Reconciliación en Perú (CVRP) en el $2003^{27}$, trabaja con relatos enunciados en grupos focales, considera que el contexto de enunciación y recepción de estos testimonios son determinantes de las formas discursivas: “[...] me interesaban este tipo de recuerdos relatados en estos grupos focales porque el contexto en el cual los testimonios son dados y recibidos es central con relación a las formas que esos testimonios adquieren” (2006, p. 82). Esto y la constante pregunta por la ética en campo: ¿Tenemos derecho a preguntar sobre experiencias traumáticas? ¿Hay límites en investigación social? ¿Cuál es la metodología "menos" violenta, invasiva, entrometida para el estudio de experiencias traumáticas? "No puedo separar los métodos de la ética: en este caso, ambos son repugnantes. Hay preguntas que no tenemos derecho a preguntar, y silencios que deben ser respetados." (2006, p. 87)

El Silencio fue una constante en estas narrativas, se decodificación fue un aprendizaje diario en las reuniones con ambas organizaciones. "Cuando termine de contar, ¿me voy a seguir acordando de lo que pasó?”, preguntó una joven a la terapeuta en una de las sesiones. Y es que, el silencio no entraba en los géneros disponibles para el contar; en la ONG fue aún más notable que en el grupo de pares, claro, a diferencia del primero, a éste no lo apuran los plazos judiciales. Tuvimos que aprender a convivir con los silencios, percatadas de que eran una constante en trabajos de este tipo: "Cuando me olvido me siento bien. Recordar (lo que pasó) incluso ahora, me vuelve loca. Se me hace muy difícil poder soportarlo. Pero cuando me olvido me siento más o menos. Es tan duro responder a sus preguntas, tan difícil volver atrás y recordarlo todo" (Theidon, 2006, p. 82).

\footnotetext{
${ }^{27}$ La Comisión tenía por objetivo examinar las causas y consecuencias del conflicto armado interno que tuvo lugar entre los ' 80 y '90 en Perú. De esta manera, Perú se unió a la creciente lista de países que habían implementado comisiones de verdad como medio de transición de un período de conflicto armado y gobierno autoritario hacia la fundación de una democracia procesual.
} 
"[...] la ruptura de las condiciones de posibilidad de la comprensión de hechos de degradación y muerte, la necesidad de hablar, la urgencia de ser escuchado, la emergencia del silencio para preservar la intimidad o el anonimato, el hueco, el vacío, el mismo dolor" (Romero, 208, p. 21) son sentires encontrados con los de una investigación que busca realizarse. Las urgencias del investigador por acceder a esas palabras y la impaciencia de una cultura de hacer investigación que -en la mayoría de los casos- es incompatible con los tiempos de las personas que intervienen en la misma. Entonces, el desafío del reflexionar metodológico radica -precisamente- allí: en la búsqueda de herramientas y técnicas que respeten, en lo posible, los tiempos de los/as otros/as, sus espacios y seguridades. Implica reconocer y detectar qué nos falta antes de ingresar a campo, ¿Es sólo una preparación teórica-metodológica? ¿Son sólo los años de experiencia en investigación? $\mathrm{O}$ es -quizás- una preparación que tiene que ver con sostener el cuerpo y prestar atención a las sensibilidades que se juegan en ese momento. $\mathrm{Si}$ investigadores en comunicación sostienen que habilitar espacios de charla (entrevistas) es habilitar la posibilidad de poner en palabras el horror y terminar de vivir la experiencia: ¿Cómo -entonces- se intenta “reparar” lo no-dicho?

\section{El Registro}

¿Cómo se registra lo no-dicho? ¿Qué contiene el diario de campo? ¿Qué y cómo se puede (y no) registrar en este campo? ¿Es posible lograr la escritura sensible, comprometida y responsable con los estándares de rigurosidad científica? ¿Cómo se escriben los análisis en torno a experiencia traumática?

El registro de campo está por orden cronológico con saltos temporales justificados por mi ausencia en algunas reuniones. Escrito en primera persona, recorre descripciones espaciales, cita de frases textuales, las características del ambiente, el detalle de algunas situaciones y al final de las hojas palabras, comentarios, frases que escuché ese día y que llamaron mi atención. En los bordes de las hojas siempre preguntas, por supuesto. ¿Qué registrar y qué no registrar del campo? ¿Qué hay del derecho al silencio y la opacidad? Tensiones constantes en este trabajo. "En el rechazo de una mujer de convertir su violación en núcleo narrativo de su subjetividad, 
podríamos ver una insistencia en el derecho de opacidad en ésta era signada por la obsesión confesional y la tiranía de la transparencia” (Theidon, 2006, p. 87). Pensemos cómo estos mecanismos operan a nivel de estándares metodológicos obligatorios en una investigación social.

Así, no registramos de cualquier modo y esto supone prestar atención a la tentación de codificar en clave conceptual la experiencia en campo. Justamente esa "[...] distancia entre el dato como 'lo dado' externamente al investigador y el dato como información empírica fotográfica y teóricamente significativa reside en el mismo investigador, el verdadero y casi único articulador entre su problema de conocimiento y su solución" (Guber, 2013, p. 144). Es tentador realizar ese pasaje de material empírico a conceptual en el mismo momento -precisamente- el registro de campo implica un proceso de comprensión gradual de las personas que intervienen en una investigación y sus múltiples situaciones de vida (Ídem).

"Si a la hora de mirar las relaciones que estudiamos nos vemos tentados a evaluar, desde nuestros propios conceptos, lo que estaría bien o mal para aquellas personas o instituciones, probablemente el resultado que obtengamos hable más de nosotros que de ellas (con el agravante de que en esa proyección aún creeremos estar haciendo etnografía de los otros." (Renoldi, 2014, p. 129)

Dialogamos y trabajamos con Renoldi a raíz de sus trabajos sobre narcotráfico y el manejo que hace en campo de lo confidencial y el secreto. Cuidadosa en su escritura de esta red que implica el trabajo con narcotráfico desde las fuerzas de seguridad del Brasil.

"El diario de campo consigna un arduo proceso que refiere tanto la obtención de información como la transformación de la información en dato y, en este mismo proceso, al pulimiento del instrumento de investigación, la investigación misma" (Guber, 2013, p. 173). Es un diálogo constante entre lo que registramos y nosotras mismas. Entonces, este diario de campo fue escrito durante las reuniones con el equipo de salud de la ONG y posterior a las reuniones con el grupo de pares. Se compuso de anotaciones extras realizadas en jornadas, congresos, simposios, charlas específicas de la temática de abuso (debido a que algunos miembros de estos grupos estuvieron en la organización, exposición o participación). Además -por entonces- me interesaban los 
discursos médicos, legales y desde distintos activismos sobre la problemática del abuso sexual infantil y de los/as abusadores/violadores. Así, el diario de campo contenía una polifonía que me costaría ordenar y sistematizar pero cerraba el mapeo de los que hablan y de lo que dicen sobre el ASI.

Con imágenes, nombres o detalles de los casos no quise trabajar por razones evidentes, preservar y resguardar la intimidad de las personas que intervinieron fue una decisión que -incluso- podía perjudicar la rigurosidad de mis datos. El punto de interés estuvo en la metodología de abordaje, seguras de que no podíamos encarar estos relatos de cualquier manera. Pensamos en función a las personas que intervinieron en la investigación.

“[...] cada vez que el etnógrafo observa y luego cuenta lo que no debería contar si obedeciera a los principios nativos de preservación de datos y lealtades está, en cierto sentido, afirmando su lealtad para con su comunidad científica, al evidenciar, de manera convincente, los resultados de su labor investigativa en términos de 'descubrimiento' y de autoridad." (Renoldi, 2014, p. 115)

Tal como menciona Renoldi, nuestro compromiso primero estuvo con las personas que involucró esta investigación y por este compromiso es que hay secretos que no escribimos y silencios que sí. De eso se tratan éstas páginas. 
VIII. ¿El fin de la buena fe en Ciencias Sociales?

Reflexiones en torno al problema de "lo ético" en trabajos científicos

¿Qué es la ética? ¿Quiénes marcan los parámetros de lo “correcto"? ¿Qué disciplinas científicas se encargan de regular el "buen manejo" de las herramientas de recolección de datos? ¿Cómo encaramos un trabajo de investigación científica que cumpla con los requisitos de rigurosidad científica sin perder la sensibilidad que atraviesa todo el análisis de recuerdos dolorosos? ¿Es posible esta tarea sin perder de vista el respeto máximo por la intimidad del que está narrando sus recuerdos más dolorosos?

El abordaje de experiencias traumáticas en campo expone no solo a los/as entrevistadas/os a un estado de vulnerabilidad altísima sino que, también, expone al investigador a una infinidad de encrucijadas éticas, políticas y filosóficas que deberá sortear (o no) para llegar (o aproximarnos) a los objetivos planteados.

La preocupación por encarar la escucha atenta y respetuosa es un interrogante no menor a la hora de encarar el trabajo y -precisamente- por la seriedad con la que se pretende encarar la labor científica es que resulta necesario dialogar con disciplinas como la psicología, la sociología y el trabajo social. Disciplinas que cuentan con herramientas pero, sobre todo, cuentan con debates para el manejo de testimonios de experiencias traumáticas, las emociones personales y la relación entre víctimas y profesionales intervinientes en la escucha. La consulta con otros profesionales para trabajar el anonimato y la confidencialidad de manera rigurosa se vuelve fundamental en sintonía con organismos nacionales e internacionales que ya cuentan con un conjunto de procedimientos en estos casos.

Decidimos incluir este apartado y empezar a dialogar con estas cuestiones que nos atraviesan no para saldar deudas sino para reflexionar desde el inicio sobre el hacer investigación. A lo largo de estos años he visto y sentido mucho escozor por la pregunta del accionar ético en ciencias sociales, sin importar en rango de investigación que posean, nadie sale "ileso" de reflexionar sobre nuestra intervención en campo cuando se trata de personas y experiencias que ponen en juego su integridad, seguridad, ánimo e intimidad. Con todo esto, revistas de gran renombre internacional ya están solicitando el aval de un Comité de Ética para la publicación de avances de trabajo o artículos. Quizás 
es hora ya de empezar a tener estas discusiones al interior de los centros de investigación, entre los claustros, en los planes de estudio y currículas sobre la necesidad (o no) de incluir estos lineamientos éticos en las formaciones de grado o como instancia de posgrado con los Comités de Ética.

\section{¿De dónde proviene la pregunta por lo ético?}

"La ética de la investigación se entiende como la responsabilidad que debe tener la ciencia y más concretamente los científicos, hacia los sujetos de investigación y la sociedad en general" (Achío Tacsan 2003, p. 85). Trata de los principios morales de los que parten (y cruzan todo el tiempo) los investigadores con los sujetos que intervienen en una investigación social, algunos autores sostienen que es una historia corta y reciente la de estas regulaciones éticas y sus orígenes se remontan a las de la bioética.

"Los comités de bioética surgieron a mediados del siglo XX para proteger los derechos de las personas como sujetos de investigaciones médicas, analizar temas moralmente controvertidos en la práctica médica, como por ejemplo los relacionados con el principio y el fin de la vida, y analizar, al igual que los comités de ética en la ciencia y la tecnología, temas vinculados con la investigación, por ejemplo en los campos de la genética y la reproducción humana." (CECTE, 2001)

A partir de la década del ' 80 esta serie de regulaciones y preguntas éticas migró al campo de las ciencias sociales, preguntas y regulaciones que luego fueron institucionalizadas. La necesidad de recurrir a marcos regulatorios que organicen el quehacer científico surgió -precisamente- a raíz de procedimientos de dudosa buena fe cometidos durante la Segunda Guerra Mundial. En Europa Occidental los debates se originaron a partir de una serie de experimentos médicos en campos de concentración nazi que implicaron el daño y/o muerte de los sujetos investigados. A partir de la década del $80 \mathrm{y}$, estimulada por principios éticos provenientes de la bioética en Europa Occidental y EEUU, se configuraron una serie de organizaciones e instituciones en torno a esa cuestión. 
"La vulnerabilidad del cuerpo humano como objeto de investigación y experimentación, puesta de manifiesto durante los juicios de Nüremberg, y su vinculación con la integridad y los derechos de las personas generó un campo especifico de reflexión ética y un conjunto normativo, el llamado Código de Nüremberg ${ }^{28}$, que no ha dejado de ampliarse." (CECTE, 2001)

La misma derivó en la inauguración del campo de la bioética y la creación del Código de Ética de Nüremberg, el mismo considera aspectos fundamentales para el trabajo con humanos como ser el consentimiento informado voluntario de los sujetos participantes de la investigación (Weindling, 2004 en Meo, 2003). Como vemos, la pregunta por la ética en campo es problemática ya que no nació en las mismas brasas de las ciencias sociales sino que proviene de otras disciplinas como la medicina y la bioética, los parámetros en las que fueron pensadas sus lineamientos corresponden a otros marcos de comprensión. ¿Resulta suficiente el accionar de Comités de Ética para investigaciones provenientes de las ciencias sociales? ¿Es suficiente su intervención para mejorar los estándares de calidad científica?

\footnotetext{
${ }^{28}$ El Código de ética médica de Nüremberg son principios que regulan la experimentación con seres humanos, los mismos son productos de los debates en los Juicios de Núremberg, al final de la Segunda Guerra Mundial. El Código responde a las deliberaciones y argumentos por las que fueron enjuiciados la jerarquía nazi y algunos médicos por el tratamiento inhumano que dieron a los prisioneros de los campos de concentración, como por ejemplo, los experimentos médicos del Dr. Josef Mengele.
} 


\section{La ética como institución}

¿Cómo resuelven institucionalmente el problema de lo ético organismos e institutos financiadores de investigaciones sociales?

Estar bajo la órbita de un centro de investigación (IIGG en aquel momento) resultó crucial para el desarrollo de este trabajo, son las reglamentaciones de las organizaciones que velan por el correcto desarrollo de una investigación las que trazaron (en algún momento) los vértices de esta investigación. Dicho esto, empecemos por situarnos en el contexto institucional: la organización del IIGG está a cargo de un Director y del Comité Académico, dividida en áreas de investigación esta tesis se inscribe en el Área de Salud y Población, en convivencia y diálogo con investigaciones principalmente de sociología. Ahora bien, toda investigación que se desarrolle bajo la órbita de este instituto debe recurrir al Reglamento en caso de dudas, el reglamento del Instituto Gino Germani (en el momento en que esta investigación fue realizada) no contemplaba al Comité de Ética dentro de su lógica de funcionamiento, asesoramiento o seguimiento de proyectos. Sólo en su página institucional (por debajo del documento Reglamento) hay un apartado que indica: 
Comité de Ética:

El 2 de marzo de 2009 la Facultad de Ciencias Sociales de la Universidad de Buenos Aires creó el Comité de Ética del Instituto de Investigaciones Gino Germani (IIGG) como instancia de evaluación, asesoramiento y difusión sobre aspectos éticos y bioéticos relacionados con las actividades de investigación concernientes al ámbito de Salud y Población que contemplen el trabajo de campo con personas o la información referida a ellas. Además podrá considerar la pertinencia de brindar su aval a aquellas investigaciones que lo requieran como exigencia y se encuentren comprendidas en las áreas de investigación del IIGG. El Comité se propone contribuir a favorecer el resguardo de los principios de la ética reconocidos en el ámbito nacional e internacional para las actividades científicas.

El Comité tendrá como objetivo evaluar los aspectos éticos de los proyectos de investigación que demanden su aval para su presentación y/o postulación ante las instancias que correspondan.

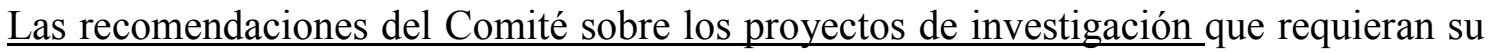
aval tendrán carácter vinculante y sólo se emitirá el aval a aquellos proyectos de investigación que cumplan con las pautas, criterios y normas que correspondan. Si la presentación debe reformularse, sólo extenderá su aval cuando el proyecto sea nuevamente reformulado y presentado atendiendo a las observaciones.

El Comité podrá ejercer funciones de asesoramiento y consulta en los casos que sean requeridos, mas no tendrá entre sus responsabilidades el seguimiento de los proyectos dictaminados.

El Comité estará constituido por 5 (cinco) miembros, que deberán proceder de disciplinas diversas a fin de garantizar la pluralidad de perspectivas disciplinares en las deliberaciones y las decisiones.

Fuente: Instituto de Investigaciones Gino Germani ${ }^{29}$. (La selección es nuestra).

\footnotetext{
${ }^{29}$ Recuperado el día 29/07/15. Disponible en $<$ http://iigg.sociales.uba.ar/reglamento/>.
} 
Sobre esto varias cuestiones llaman la atención. En principio, se trata de un Comité con escasos años de funcionamiento en relación a los años con los que cuenta el Instituto $^{30}$. Esto en coincidencia con lo que plantean algunas autoras (Meo, 2010) sobre las reflexiones en torno a los comités de ética en la Argentina, planteos considerados aún como un tema marginal dentro del espectro del debate científico. En nuestro país la exigencia por la pregunta "ética" se vio a raíz de la creciente institucionalización -a través de los organismos financiadores- de la práctica científica: la creación del Comité Nacional de Ética en la Ciencia y la Tecnología (CECTE) en el 2001 y del Comité Ético del CONICET en el 2004. La puesta en circulación de distintos códigos de ética o de conducta producidos por los mismos organismos financiadores como el CONICET o por asociaciones de profesionales como el Consejo Profesional de Sociología los que instalaron la pregunta por "lo ético" en el accionar científico. Esto demuestra no solo la emergencia por un debate integral quizás del problema de la ética en investigación social, sino la ausencia de voces que den cuenta de estos debates. La escasez de artículos en revistas científicas en áreas específicas de las ciencias sociales así lo demuestra.

Lo segundo a señalar es el recuadro, por fuera del reglamento interno del instituto, que indica las funciones y miembros del Comité. El hecho de que el documento normativo que regula el funcionamiento del IIGG no contemple las funciones y creación de este comité es llamativo, vale aclarar que la aprobación de dicho reglamento es posterior a la creación del Comité de Ética ${ }^{31}$, según los años estipulados. Si bien mi formación proviene de otra disciplina científica, la dirección de

\footnotetext{
${ }^{30}$ El Instituto de Investigaciones Gino Germani data del año 1940, cuando el historiador Ricardo Levene, organiza el Instituto de Sociología en la Facultad de Filosofía y Letras de la Universidad de Buenos Aires. En los '60 su director, el investigador italiano Gino Germani, impulsó la denominada "Sociología Científica", investigaciones orientadas hacia la producción de conocimiento sobre los problemas sociales de la realidad nacional y de la sociedad contemporánea. Este proceso institucional padeció sucesivas interrupciones debido a las intervenciones que sufrió la Universidad durante los gobiernos de facto que se sucedieron en el país entre 1966 y 1983. En 1984, con el retorno de la democracia, se inicia el proceso de normalización y creación de la Facultad de Ciencias Sociales y de su Instituto de Investigaciones. En este período tuvo lugar la creación de la Facultad de Ciencias Sociales en 1988 y la elección del primer Comité Académico de su Instituto de Investigaciones en 1992, por sufragio de sus distintos claustros. En diciembre de 1993, el Comité Académico propuso la denominación de "Instituto de Investigaciones Gino Germani" en homenaje al aporte del sociólogo italiano al desarrollo de la investigación en Ciencias Sociales en nuestro país. (Recuperado el día 29/07/15. Disponible $<\underline{\text { http://iigg.sociales.uba.ar/historia/ }>\text { ) }}$

${ }^{31}$ El comité de Ética se crea en el 2009 y el reglamento del IIGG se aprueba en el 2013.
} 
esta tesis está a cargo de una socióloga, esto inevitablemente me llevó al diálogo (no sin algunos conflictos) con esta disciplina, sin contar con la fuerte presencia de sus egresados en el IIGG: colegas e interlocutores/as diarios en reuniones, congresos, articulaciones, etc. Fueron -precisamente- estos diálogos de cerca con la sociología los que me llevaron a la problematización de la cuestión ética en la labor científica.

Como menciona en su apartado, la función del Comité que se desprende del IIGG, es "evaluar los aspectos éticos de los proyectos de investigación que demanden su aval para su presentación y/o postulación ante las instancias que correspondan”, cabe aclarar que este comité solo hará recomendaciones a aquellos proyectos que cumplan con los requisitos, pautas y criterios que correspondan"... esto sin aclarar o detallar cuáles son (precisamente) esos requisitos, pautas o criterios que debería cumplir un proyecto de investigación para poder ser evaluado. Dicho comité de ética se abstiene de revisar un proyecto cuyo trabajo de campo ha sido iniciado o realizado o que haya atravesado otros ámbitos de evaluación, supone una evaluación primera y previa a toda exploración siquiera del campo.

Si seguimos con la lectura del recuadro anterior, el CE (Comité de Ética) no hace seguimientos a proyectos en curso, ni establece pautas o normativas para recaudo de los investigadores. Su función recae en la supervisión de los consentimientos informados que presente el investigador. El aval no será expedido hasta que el investigador haga las reformulaciones que recomiende el comité al proyecto y vuelva a entregarlo. El dato: este Comité no evalúa proyectos de investigación sólo consentimientos informados. Tampoco es obligación pasar por el Comité, no hay pautas que obliguen a los proyectos a atravesar por esta instancia, todo queda a criterio personal (y político) de cada investigador.

A pesar de ser uno de los centros de investigación más grandes del país y Latinoamérica, el IIGG no cuenta con una normativa clara para la intervención (o no) de su CE, ante qué casos intervenir, cuales seguir; tampoco se adelanta o supervisa la metodología de cada proyecto. En el caso de los/as becarios/as que somos beneficiarios de becas de investigación y estudio del CONICET, éste último no cuenta con un CE que vele por estos recaudos pero sí con una serie de "Lineamientos éticos para el comportamiento ético en las Ciencias Sociales y Humanas". 
El documento en cuestión nos arroja algunos parámetros de trabajo, fue aprobado en el 2006 por el Comité de Ética del CONICET (CONICET, Comité de ética, 2006). Este documento es una guía para los/as investigadores/as sobre las "cuestiones y actitudes éticas", el cuidado de sus conductas y decisiones (CONICET Comité de ética, 2006, p. 1).

En relación a los sujetos investigados, el CONICET sostiene: 
A. Principios éticos que rigen la relación entre las personas que son sujeto de investigación para las ciencias sociales y humanidades:

1. Se debe respetar la dignidad, la libertad y la autodeterminación del individuo.

2. Las personas que son sujeto de investigación no pueden ser sometidas a perjuicio, riesgo o a cualquier tipo de presión.

3. Los proyectos de investigación no deben realizarse sin haber obtenido el consentimiento libre e informado de los participantes. Los sujetos de investigación pueden en todo momento interrumpir su participación sin ninguna consecuencia para ellos.

4. A los sujetos de investigación se les debe proveer toda la información necesaria de tal manera que puedan comprender las consecuencias de participar en el proyecto, el tipo y el propósito de la investigación y las fuentes de financiamiento.

5. Los investigadores tienen la responsabilidad de no generar falsas expectativas, comunicando a los sujetos el alcance de la investigación.

6. En caso de ser solicitado, los investigadores tienen la obligación de informar a los sujetos de investigación los resultados disponibles en forma apropiada y comprensible.

7. Cuando los que participan en la investigación son niños, jóvenes o cualquier grupo altamente vulnerable deben ser protegidos conforme a sus características y a las normativas vigentes referentes a los Derechos del Niño.

8. Los investigadores han de respetar la privacidad y están obligados a la confidencialidad de toda información. En particular deben ser cuidadosos con los archivos o listados que identifiquen a los individuos participantes.

9. La información no puede ser utilizada sin autorización para otros propósitos, en especial para uso comercial o administrativo.

10. Los investigadores deben tratar con respeto los valores y concepciones de los participantes.

11. En la investigación sobre culturas es necesario dialogar con sus representantes sin dejar de tener en cuenta en todo momento su identidad, los derechos humanos y las pautas de este lineamiento.

12. Se deben preservar los monumentos históricos, los restos arqueológicos y cualquier patrimonio cultural.

13. Deben ser tratados con respeto los restos humanos involucrados en investigaciones.

Fuente: CONICET Comité de ética 2006. (La selección es nuestra). 
Si bien CONICET reconoce como grupo vulnerable población de niños, niñas y jóvenes, es decir, deja claro que es necesario un tratamiento especial para los mismos, no da pautas de trabajo o cuidados para que el investigador pueda trabajar con los mismos. Meo (2010) atribuye esto a una falta de discusión local sobre la problemática del abordaje ético en estos espacios: está la visibilidad del problema pero no hay coordenadas para salir del callejón. Decimos CONICET porque es el organismo que financia el presente trabajo pero sabemos que el problema y la discusión por la ética profesional en Ciencias Sociales exceden y son debates no saldados. Atraviesa todos los órdenes, no solo el institucional sino el personal, profesional.

En tercer lugar, y a modo comparativo, tenemos al CECTE: Comité Nacional de Ética en la Ciencia y la Tecnología que depende del Ministerio de Ciencia y Tecnología e Innovación Productiva. El mismo fue creado en el 2001 en un contexto de crisis no solo económica, sino social y cultural, de pérdida de confianza en las ciencias, así reza su documento base. Fue el primero en crearse a nivel nacional junto con el de CONICET en el 2004. Analiza problemas vinculados a la relación entre la ciencia, la tecnología y la sociedad y problemas dentro del ámbito de la comunidad de investigadores científicos y tecnológicos y de las instituciones del sector. Recordemos que este Comité elabora protocolos para la investigación con seres humanos, que abarcan desde las ciencias de la vida a las sociales, y para la investigación científica y tecnológica en relación con el cuidado ambiental (CECTE, 2001).

La creación de este organismo sin duda visibiliza la emergencia por dar este debate en las ciencias. Es el primero de alcance nacional y si bien plantea desde el inicio su interés por las ciencias sociales como por las ciencias de la vida (biológicas) "de las 25 actuaciones escritas que ha hecho desde su creación, ninguna trata conflictos o dilemas éticos vinculados al desarrollo de la investigación social (ya sea en términos generales o referidos a algún estudio en particular)”. (Meo, 2010, p. 16)

Lo que queremos dejar entrever en estas líneas son los baches o silencios que los debates por la ética suscitan a nivel institucional. Aún sin mucho material para dar esta discusión, sabemos que fue iniciativa de los organismos financiadores el sentar las bases para una "correcta" investigación, para las que estuvieran bajo su órbita por lo menos. Controversial por lo que significa suponer que hay una ética para la labor científica, el contexto político -económico y social van a determinar estas discusiones, aun así, esto supone un extrañamiento en algunos científicos/as al escuchar nombrar a 
un comité de ética. ¿La ética de quién? ¿Hacia quién? ¿Cuáles son las disciplinas autorizadas para velar por la correcta y honesta ejecución de un proyecto? ¿Cuántas éticas hay?

\section{Cierre}

Hasta aquí buscamos abordar integralmente la problemática, respetando tiempos, con cuidados que dialogaran en todo momento con el trabajo. Reconocer a otras organizaciones gubernamentales o civiles y disciplinas con años de debates en torno a lo confidencial y el manejo del secreto profesional es otra de las propuestas de este trabajo. En cuanto a cuidados y el respeto por el otro no somos tan distintas unas disciplinas de otras, entonces, la articulación y el diálogo pareciera ser la "salida" a algunas encrucijadas que se nos presentan a lo largo del trabajo de campo.

Si bien sabemos que estas discusiones exceden los planteos de este trabajo, queda para futuras líneas seguir estirando de estos hilos, estimuladas por la reflexión pero, sobre todo, por el anhelo de una ciencia más comprometida, solidaria y respetuosa. Suponemos que el trabajo comprometido con las personas que intervienen en una investigación no debiera ser, quizás, una instancia evaluativa posterior de un comité en particular, sino, constitutiva de la formación plasmada en sus programas curriculares de los profesionales/científicos formados en las Universidades Públicas y Privadas. Formados con principios éticos desde el inicio, los/as científicos/as no necesariamente debiéramos pasar por una instancia "evaluativa" si contamos en nuestro haber con esta mirada. Si el manejo cuidadoso de los materiales de campo fuera parte de la formación de todas las carreras de grado que implican investigar, el transitar por un Comité de Ética no sería necesario. Consideramos fundamental la labor de un Comité, pero no dejamos de preguntarnos por las disciplinas autorizadas a evaluar cuán ético o no es un trabajo y cómo debieran proceder en campo. Como vimos, el abordaje de crímenes sexuales merecen algo más que la evaluación de los Consentimientos Informados (función del Comité de Ética) que el investigador pueda llegar a presentar, implican la reflexión metodológica integral del problema y el resguardo absoluto de los materiales de campo. 


\begin{abstract}
"Bueno, déjenme decirles... Cuando se es un chico pobre de una familia pobre, la religión cuenta mucho. Y cuando un sacerdote te presta atención, es algo grande. Te pide que reúnas las donaciones, o saques la basura, y te sientes especial. Es como si Dios te pidiera ayuda. Quizá es un poco raro cuando te cuenta un... chiste verde, pero ahora comparten un secreto juntos. Así que no le das importancia. Luego te muestra una revista porno. Y no le das importancia, y sigues así.. Y sigues así. Hasta que un día te pide que lo masturbes o se la chu**. Y aceptas porque te sientes atrapado, porque te ha encerrado. Es dificil decirle que no a Dios, ¿cierto? Verán... Es importante entender que esto no... es sólo abuso físico, sino es un abuso espiritual también. Cuando un sacerdote te hace esto, te despoja de tu fe. Es un disparo al alma ${ }^{, 32}$.
\end{abstract}

${ }^{32}$ De la película "Spotlight" (Primera Plana) de 2015, ganadora de un Premio Oscar a Mejor Película. Extracto de un diálogo entre un sobreviviente de abusos sexuales cometidos al interior de una escuela católica cuando era niño y el equipo de investigación periodística. 


\title{
Capítulo 3
}

\begin{abstract}
Análisis
V. Primera Situación Comunicativa

Una historia de la Infancia

"Se dice muchas veces que el abuso sexual durante la infancia es la muerte al alma.

Nosotras aquí decimos que es más bien un disparo directo al corazón de ese niño." -Primera reunión con las autoridades de la ONG-
\end{abstract}

Encarar un proceso de investigación científica que trabaje con relatos de experiencia traumática que tienen que ver con el abuso sexual durante la infancia involucra posicionamientos éticos, políticos y emocionales que es necesario "ordenar" antes o durante la escritura del informe. No por nada las personas que atravesaron esta experiencia se denominan a sí mismas como "sobrevivientes", son sobrevivientes a la degradación de la condición humana, a la convivencia con la muerte, a la traición que significa la pérdida de fe y confianza, se supone que el resguardo y la tutela de ese niño o niña está al cuidado de esa persona que lo está abusando, lo está violando. Habría que imaginarse al lobo dentro del corral de ovejas, esa confianza y esa atención que reciben los/as niños/as es aprovechada por estas personas etiquetadas de "perversos/as", monstruos, anormales, enfermos y otra serie de calificativos del orden de lo mitológico, externo, extraordinario, ajeno, "otro"... sin embargo, el horror y el espanto que producen estos crímenes tiene que ver con la incapacidad de escapar y de pedir ayuda de las víctimas. ¿A quién recurrir si los mismos abusadores se encuentran dentro del hogar familiar? ¿A quién pedir ayuda si el lugar donde debieran sentirse seguros de los males externos es la mismísima jaula del lobo del cual intentan escapar? Ni hablar de la fama 
de fabuladores y mentirosos que a lo largo de los años los adultos supieron imponer a los niños/as, "inventan", "fabulan", "imaginan", "mienten" son todas atribuciones que por el sólo hecho de ser niños y niñas reciben: si revisamos nuestras propias historias de vida encontraremos alguna anécdota, comentario, situación, acusación o llamado de atención en relación a este imaginario que usualmente el mundo adulto posee sobre la infancia. Y es que la infancia como categoría es un invento moderno, la niñez no siempre fue considerada como tal y mucho menos sus cuidados y protecciones, de hecho la historia de la infancia lejos está de ser reconstruida como la de las mujeres. Diversos autores sobre la temática coinciden en afirmar en la rareza de los estudios sobre la infancia, la misma tuvo que ser reconstruida a partir de relatos históricos sobre otros sucesos y actores/as, pero no fueron un objeto en sí mismo. Bringiotti (1999) hace un recorrido por los estudios y las disciplinas que han abordado el maltrato infantil desde la incorporación del concepto de "niño apaleado" que hace Kempe. Este trabajo es producto de varios años dedicados a la infancia desde la aparición del concepto de "infancia" hasta las disciplinas actuales que estudian el maltrato infantil. La contextualización histórica que hace de la figura del niño maltratado da cuenta del poco tratamiento no sólo histórico sino social (en cuanto a asistencias y tratamientos) que ha tenido la problemática. Como es reciente esa categoría también lo son los criterios para establecer la definición y las tipologías del maltrato (como ser abuso emocional, sexual, físico, negligencia física), la autora hace un recorrido descriptivo sobre las distintas formas que adquiere ese maltrato, por ejemplo, cita a Badinter (1991) quién se refiere a la historia del amor maternal del siglo XVII al XX -que si bien la protagonista principal es la mujer como foco de análisis- es en el "maternaje" donde se ve ligada la figura del niño y su crecimiento.

Así, la infancia (o la figura del niño ${ }^{33}$ ) es una categoría moderna. Para que el mismo sea considerado como sujeto de derecho tuvo que pasar mucha historia asociada a los cambios en los conceptos de familia e infancia: pasó mucho tiempo hasta que reconocieran sus derechos. La ignorancia de su sistema cognitivo, físico y social contribuyó no solo a su invisibilización en términos de derechos sino como población sensible de ser cuidada, de recibir amor y protección. De hecho algunos autores sostienen que el concepto de niñez no existía en la Edad Media (Ariés).

\footnotetext{
${ }^{33}$ En principio y los primeros debates daban cuenta del niño varón. Las feministas de la llamada Tercer Ola serán las que pondrán la atención en la diversidad del lenguaje (también).
} 
De Mausse (1974) define seis modos diferentes de relaciones paterno-filiales a lo largo de la historia (citado en Bringiotti):

a) "Infanticidio (antigüedad a siglo IV d.C.). Predominaba el homicidio del menor, sobre todo de las niñas, los hijos ilegítimos y los discapacitados.

b) Abandono (siglos IV a XIII). Una vez que disminuye el infanticidio, la práctica común era el abandono en manos de la nodriza, en el monasterio o convento, darlo en adopción, como rehén, abandonarlo en los bosques o mantenerlo en el hogar en situación de grave abandono afectivo. Las palizas eran frecuentes por la maldad inherente demostrado por el niño/a.

c) Ambivalencia (siglos XIV a XVII). El niño/a se incluye en la vida familiar siendo receptor de proyecciones peligrosas; por lo tanto se lo debe moldear, evitando excesos y conductas inapropiadas. Aparecen los primeros manuales de orientación educativa, pero al mismo tiempo se despierta el temor por las diferencias que comienzan a percibirse en el niño/a con respecto al adulto.

d) Intromisión o intrusión (siglo XVIII). Los padres "penetran” en el niño, en su ira, su alimentación, sus necesidades, su mente, sus hábitos. Se les pegaba sin lastimar y se los amenaza con culpa. El niñola ya no es visto como amenaza y es en este periodo que surgen la pediatría y el cuidado de la salud infantil.

e) Socialización (siglo XIX a XX). La crianza de los hijos consiste en guiarlos, enseñarles a adaptarse y socializarse. Incluye tanto la teoría de Freud, como el conductismo de Skinner y las teorías psicodinámicas, cognitivas y familiares.

f) Ayuda (mediados del siglo XX). En este método se enfatiza que el niño/a sabe mejor que los padres lo que necesita en cada etapa de su vida, sin castigos pero orientando y brindando lo que necesitan en cada etapa. Esta modalidad se encuentra aún en sus inicios y ha dado origen a niños/as más afectuosos, amables y no temerosos de la autoridad." (De Mausse 1974 en Bringiotti 1999, pp. 23-24)

Durante la revolución industrial los niños y las niñas eran sometidos/as a largas y pesadas jornadas laborales, ni hablar de las sociedades antiguas donde los/as sacrificaban con fines rituales. Imaginemos que hoy esté legitimado golpear o castigar con hambre al niño o niña por realizar insatisfactoriamente un trabajo o una travesura, por aquel entonces el niño era considerado como un hombre pequeño, con un tamaño 
aprovechable para tareas domésticas pesadas o trabajos forzados que requerían de cierta delicadeza en las manos. Estos cambios a como entendemos hoy la infancia se logró con el avance de la medicina y los estudios que pusieron el ojo sobre las mujeres, a partir del conocimiento de su sistema cognitivo y físico las sociedades modernas entendimos que es población vulnerada y requiere de cuidados especiales. La importancia del cuidado durante los primeros meses asociado a la lactancia y estimulación apareció mucho después de que la medicina detectara casos de maltrato. No fue hasta finales del SXIX que apareció el primer caso documentado de maltrato infantil y fue en Estados Unidos, se trató de una niña de 9 años -Mary Ellen Wilson- quien recibiera terribles golpizas y otra serie de maltratos por parte de su familia, fue una trabajadora de caridad quien detectó esta situación e intenta protegerla. El único problema era que el país no contaba con una legislación ni organizaciones civiles que protegieran a la infancia. No hubo amparo legal al cual recurrir. Así tuvo que acudir a la Sociedad Protectora de Animales para iniciar el proceso legal y apelar a la "Ley contra la crueldad hacia los Animales": el argumento fue que la niña pertenecía al mundo animal y por lo tanto debía ser protegida. Una historia de la infancia de abandonos y muertes. Fue a raíz del avance de los estudios en pediatría, psicología evolutiva e infantil, la pedagogía y el derecho lo que llevaron a pensar al niño/a como un sujeto diferente (Bringiotti, 1999). Como mencionamos, la mayor parte del material para reconstruir la historia de la infancia se basó en fuentes secundarias y muy pocas fuentes primarias.

El primer profesional de la salud que definió el abuso sexual infantil fue Kempe recién en 1978, considerándolo como:

“[...] la participación de niños y/o adolescentes dependientes e inmaduros, en actividades sexuales que no están en condiciones de comprender, que son inapropiadas para su edad y su desarrollo psicosexual, para las que son incapaces de dar su consentimiento y que transgreden los tabúes y reglas familiares y sociales.” (Kempe en Pereda Beltrán, 2006, p.15) 
Con esto dicho, y por si fuera poco, buscamos reflexionar sobre una población que tiene una historia de desgracias y muertes, invisibilizada, donde las condiciones de su existencia nunca fueron buenas sino adversas. Bien lo dijo Marita Müller -referente nacional en el tema de abuso sexual, especialista y profesional en psicología- en oportunidad de un Congreso sobre Maltrato y Violencia, "la historia de la infancia es una historia de horror y dolor".

\section{Cruces}

La cámara gesell y las reuniones del grupo de pares, para esta investigación, son consideradas como situaciones comunicativas; mencionado en el capítulo anterior, la comprensión de un enunciado va a depender no solo de su parte verbal sino también de su parte extraverbal.

"Acordemos llamar con un término que ya es conocido, situación, a los tres aspectos sobrentendidos de la parte extraverbal de la enunciación encontrados por nosotros: el espacio y el tiempo en el que ocurre la enunciación -el dónde y el cuándo-, el objeto o el tema sobre el que ocurre la enunciación -aquello de lo que se habla- y la actitud de los hablantes frente a lo que ocurre - la valoración." (Bajtín, 1998, p. 59)

Con esto decimos que parte del sentido que otorgamos a los enunciados más su ubicación en la trama comunicacional va a determinar no solo su codificación, sino su decodificación. "En el momento en que un hecho histórico pasa bajo el signo del discurso se somete a todas las 'reglas' formales y complejas a través de las cuales el lenguaje significa. Paradójicamente, el acontecimiento debe convertirse en una 'historia' antes de convertirse en un acontecimiento comunicativo" (Hall, 1980, p.1). Es este pasaje de formas lo que nos interesa ver y como en el análisis (pasaje a forma académica epistemológica-metodológica) de esas enunciaciones en dos situaciones comunicativas concretas es atravesada por la misma (de)codificación de la autora de esta tesis, ¿cómo a partir de dos corrientes teóricas (estudios de géneros/sexualidades y estudios culturales) analizamos y a la vez volvemos relato la experiencia traumática del 
abuso sexual? Al mismo tiempo ¿cómo construyo narrativa académica de sus relatos? Los mismos son determinados por estas situaciones comunicativas, que a su vez y en cumplimiento de protocolos científicos, nacionales $\mathrm{y}$ locales tienen formas $\mathrm{e}$ informaciones específicas.

Entonces (y para organizarnos) vemos que tenemos varios niveles de análisis y reflexión, esto es, los niveles y pasajes de formas que sufre la experiencia traumática: de la experiencia del dolor a relato enmarcado en determinadas situaciones comunicativas, a documento judicial o experiencial, a análisis y codificación académica epistemológica-metodológica. Todas estas transformaciones buscaremos ver a partir de la reflexión de los mismos lugares de reflexión y enunciación, incorporando ambas corrientes teóricas que ayudarán a poner en crisis (todo el tiempo) la experiencia como material sensible de ser analizado y el lugar político privilegiado del investigador a la hora de construir estas narrativas.

Así esperamos ver como el dónde y el cuándo va a determinar aquello de lo que se habla y su valoración, reiterándose aquello de lo que se habla (me pregunto) en otras situaciones comunicativas más no así su valoración. $\mathrm{Y}$ en este desgranar y desarmar los relatos sobre experiencia traumática vamos a ver cómo determinados factores y elementos van a contribuir en el pasaje de la experiencia al relato, pero no será cualquier relato sino aquel confeccionado bajo determinadas condiciones de enunciación y producción. "Lo que es necesario poner en cuestión, es la ecuación demasiado simple entre vida y vivido. Una vida no es más que un fenómeno biológico en tanto la vida no sea interpretada. Y en la interpretación, la ficción desempeña un papel mediador considerable.” (Ricoeur, 2006, p.16)

Con respecto al problema de la ficcionalidad, nos proponemos -no sin cierta cautela- preguntarnos por la utilización de esa mediación en (durante/entre) los testimonios, antes de descifrar qué es y qué no es ficción vale preguntarse: ¿Qué usos y lugares tienen los trazos de ficción en esas $t(d)$ ramas narrativas que pretenden ser verídicas y fiables? Evitar las lecturas inocentes en una primera instancia del trabajo no es tarea sencilla.

El quiebre emocional que provocan la escucha y la puesta del cuerpo al relato constituyen una exposición límite: la escucha y el cuerpo deben estar preparados para escuchar al otro. 
En estos vericuetos coincidimos con Elizalde cuando sostiene (la necesidad de) "preguntarnos por el lugar que ocupamos como investigadores/as en cada momento de nuestro trabajo científico, desnaturalizar la matriz ideológica con la que operamos para pensar las diferencias propias y ajenas, e instalar la duda y la provisoriedad -alejando la certidumbre- en el diálogo con el/la otro/a y en su registro etnográfico pueden ser vías posibles que, en vez de permitirnos hablar por y de las experiencias de la 'alteridad cultural' (de las mujeres, los/as jóvenes, los sectores populares, etc.), nos posibilite el encuentro concreto con su humanidad, en su doble acepción ética y politica" (2008, p. 28).

En(tre) estas marañas Elizalde nos ofrece un poco de luz al túnel, la ubicuidad y su reflexión constante podría, quizás, ser una alternativa a las trampas de la objetividad y es capaz -además- de poner en evidencia el poder de la palabra del investigador. ¿El trabajo (así planteado) habilita la pregunta por el carácter sensible y político de los materiales de estudio? ¿Es necesario incorporar el estatuto sensible de la experiencia visceral e inenarrable de los niños y niñas abusadas y la reacción emocional de quién escucha al análisis?

Ya a esta altura estamos en condiciones de tensionar algunas cuerdas más y preguntarnos: ¿Por qué hay que contar el dolor? ¿Podríamos pensar en términos de derecho al olvido? ¿Es posible olvidar -y si no fuera así- es posible no contar? En un escenario donde pareciera que todo está a la vista, publicado, escrito, dicho, sentido, donde la denuncia y los procedimientos para llegar a ese relato son obligatorios ¿Qué tipo de resguardo tenemos con respecto a nuestros propios relatos, a nuestros propios recuerdos? Y es que no sólo la enunciación tiene límites sino la propia representación, ¿hay lenguaje allí donde todo es dolor? La exposición a situaciones límites llevan también al límite la posibilidad misma de lo narrable (Aranguren Romero, 2010).

¿Dónde está el límite de lo ético, de lo político y lo epistémico-metodológico? allí donde hablamos del dolor del otro, donde la escucha efectiva se traduce en hablar en nombre del otro, en nombre de su dolor para la producción de cualquier documento público. Un escenario para pensar esto son las intervenciones judiciales en caso de abuso sexual a niños y niñas y adolescentes. ¿Cuáles son las condiciones de enunciación de estos testimonios? La creación de un espacio para la escucha de las víctimas no 
necesariamente viene a salvar estas tensiones éticas y políticas que sobrevuelan la producción del testimonio. Por ejemplo, previo a la implementación de la cámara gesell en el país los niños y niñas debían testimoniar frente al juez, las modificaciones del Código Penal y sobre todo el artículo 221 bis que incorpora el uso de cámara gesell para menores de 18 años, reconoció con estas modificaciones la incapacidad de los miembros del tribunal para tomar declaraciones al niño o niña sin que sea revictimizado. Reconoce y visibiliza el accionar y el saber de otras disciplinas como la psicología para la toma de testimonio, muchas veces convertida en la única prueba con la que cuentan (¡miren sí será imprescindible profesionales específicos para la toma de este testimonio!). Aún así, y con la creación de estos (nuevos) espacios, las encrucijadas éticas y políticas no fueron saldadas: una de las maneras que posee el niño o niña para comunicar su dolor es a través de dibujos y juegos, elementos que son decodificados por la profesional de la salud. ¿Usted es la única que puede interpretar esos signos como indicadores de abuso?, preguntó en más de una ocasión un juez incrédulo. "¿Es posible que los miembros de este tribunal realicen la misma interpretación?" Siempre con un dejo de sospecha en estas interpretaciones.

Aquí lo que ponen en cuestión, en realidad, es la propia legitimidad de una disciplina como la psicología para actuar en casos de abuso sexual a niños y niñas y su "real" contribución con sus materiales a la causa como prueba. Ponen sobre la mesa la trampa sectaria de la disciplina y su casi exclusividad para el trabajo con víctimas. ¿Qué costos tiene que todavía no hayamos podido avanzar como comunidad universitaria/académica en estos espacios donde una sola disciplina no puede dar batalla? No fueron pocas las veces en que el fiscal o el juez de parte pusieron en duda la capacidad, formación y experiencia de la psicóloga que en ese momento fue llamada a declarar o a presentar pericia en la causa, ellas no están protegidas por la ley que protege a los niños y niñas así es que no dudaron en ponerlas a declarar justo enfrente de los acusados.

Entonces, siempre el relato de la experiencia del niño/a estará mediado ya sea tecnológicamente a través del dispositivo de cámara gesell, a través de sus producciones didácticas- dentro del mismo espacio- y a través de un/a tercero/a que vendría a ser la terapeuta. Esto nos lleva a preguntarnos, ¿es posible acceder a la experiencia traumática del niño o niña en primera persona sin tantas mediaciones (valga la redundancia) en el medio? ¿Es posible producir conocimiento científico sobre un otro? ¿Cómo salirse de 
cierta fascinación, estupor o indignación que causan los fenómenos de violencia para construir un "análisis razonado"?

Estos recorridos institucionales implica el proceso de codificación de una experiencia de dolor y sufrimiento a una narrativa experiencial, científica o un relato jurídico sensible de ser utilizado como prueba, entonces estos relatos respetan normas y a veces deben tener determinas formas para transformar ese dolor en una escritura 0 secuencia "utilitaria" a los fines de ¿beneficiar? a quién fuera lastimado. Estas reglas a la que se atienen para su traducción es la violencia epistémica (2008) de la que habla Rebecca Saunders, en un contexto de toma de testimonio por parte de la Comisión de la Verdad y Reconciliación (sigla original TRC) en África del Sur, su preocupación recorre los resultados de traducir el sufrimiento humano en un código universal de derechos humanos, ¿qué se pierde en esa traducción? ¿Abarca lo suficiente esa codificación que hacen las Comisiones de la Verdad?

Para la sistematización de estos recuerdos dolorosos la Comisión utiliza desde 1996 un software denominado Infocomm que procesa y sistematiza para que esos relatos puedan ser leídos en "toda la nación". Este procesador de datos con un vocabulario específico tenia posibilidad de sistematizar cuarenta y ocho tipos de violaciones y reconocía tres sujetos (víctima, perpetrador y/o testigo) cualquier relato que vaya por fuera o no contemple estas posibilidades no era tomado o considerado por los registros de la Comisión. Y he aquí la paradoja, ¿Cómo esta codificación que viene del lado del "tiránico" (del conquistador, del poderoso) sirve en términos utilitarios a las víctimas? Saunders indaga sobre esta paradoja. Hay que "ordenar" tantos recuerdos, ubicar en tiempo y espacio el suceso, a los personajes, a los cómplices, ¿qué se pierde en este proceso?

El problema de clasificar y escribir sobre el sufrimiento es reconstruir la trama narrativa allí donde el lenguaje se había quebrado y se imponen narrativas para el contar, violentando así otros marcos para el sentir y compartir. Su sufrimiento así codificado ya está en manos de un otro que hará uso de esas nuevas formas (Saunders) ya sea un juez, abogado o fiscal, ya deja de pertenecerle a la víctima y pasa a la arena de lo público. ¿Cómo se escribe aquello que se siente? ¿Contamos con insumos para reflexionar(lo)? 
Saunders va a decir, por un lado, esta sistematización y relevamiento permitió ver la inmensidad de los abusos y su sistematicidad a nivel nacional; pero, por el otro, en esa traducción en un lenguaje de derechos humanos se perdieron importantes elementos que tienen que ver con los procesos personales de sanación de ese trauma a nivel corporal e interno.

Por su lado, Kimberly Theidon en 1995 llevó adelante una investigación con la Comisión de la Verdad en Perú para ver la relación de las mujeres y la guerra sobre los años en que Sendero Luminoso y las Fuerzas Armadas Peruanas se disputaron no solo la verdad sino el dominio del territorio peruano. Una de las conclusiones de la antropóloga fue que estas Comisiones de la Verdad son "victimo-céntricas" sin mucho margen por fuera de este núcleo narrativo/reflexivo para la aparición de otro tipo de testimonios. ¿Qué queda por fuera de este núcleo narrativo?, reflexiona sobre esta tensión. ¿Qué pasa cuando los relatos van por fuera de la figura de la víctima, el sufrimiento y el dolor? "En el rechazo de una mujer de convertir su violación en núcleo narrativo de su subjetividad, podríamos ver una insistencia en el derecho de opacidad en esta era signada por la obsesión confesional y la tiranía de la transparencia" (Theidon, 2006, p. 87). Uno de los problemas con los que se encontraba la Comisión en la toma de testimonios de los y las campesinas que sufrieron algún tipo de violencia era que los varones "acaparaban" los espacios para testimoniar sin margen para que las mujeres pudieran expresarse libremente. Las censuraban o cohibían a la hora de hablar, esto llevó a reorganizar los encuentros por grupos de mujeres separadas de los varones, convencidas de que las condiciones de enunciación de los testimonios de sobrevivientes eran cruciales para la misma enunciación. Theidon se para en una cuerda floja, es el derecho a la opacidad y al silencio, cuando un testimonio se vuelve intercambiable o "receptoras legítimas" de "ayuda humanitaria" empiezan a accionar elementos coercitivos en un contexto de reparación de guerra. Esta tensión en la que se mueve Theidon es un insumo para reflexionar qué otros espacios narrativos deberían habilitar (las comisiones de la verdad) para contar con perspectiva de género en su accionar. Entonces, esta sensibilidad de género que buscan apelar, iría más allá de que las mujeres "cuenten" sobre sus violaciones, más bien iría por desarrollar otras (¿nuevas?) formas de escuchar y de contar lo que ellas tengan para decir de la guerra. 
Pero, ¿cuál es el problema de todo esto? la escucha afectiva, la representación del otro y la violencia epistémica. ¿Qué pasa cuando eso intimísimo pasa a la arena de lo público? Lo irracional busca ser ubicado o contado dentro de los carriles de lo racional, lo compartible. La pregunta es: ¿Se puede producir conocimiento científico sobre el padecimiento del otro?

\section{Una situación comunicativa creada para el contar}

El consultorio donde se llevan a cabo las entrevistas es una habitación con un espejo del mismo tamaño que una de sus paredes para que pueda ser reflejado lo que sucede entre la terapeuta y el niño o niña. Vemos dos baúles de madera repletos de juguetes, en el suelo una alfombra cuadrada ubicada en una de las esquinas con almohadones en el suelo para poder jugar sentado en el mismo. Dos mesas enfrentan el gran espejo, una pequeña para niños y niñas y otra mesa más alta para atender a adolescentes, hay una pizarra en la cual pueden dibujar o escribir y papeles y colores a su disposición para realizar dibujos o los test requeridos por la terapeuta. La cámara y el micrófono que registra todo lo que sucede en la habitación está fijo en una de las esquinas de la habitación y nunca son apagadas, al momento del ingreso a la habitación durante la entrevista permanece encendida en todo momento. Del otro lado de estas (dos) cámaras (con las que cuenta la ONG) no suele haber personas observando, salvo que por un pedido explícito del juez solicitan que alguna de las partes que intervienen en un juicio presencie la sesión. Nunca del lado del consultorio, siempre del otro lado de la cámara. El equipamiento que registra estas escenas (computadora) se encuentra en una habitación continua y no es vista por las personas que intervienen en ese momento en la sesión. Las imágenes y el sonido no son de buena calidad pero no habría problema (en principio) con esto puesto que la gran mayoría (sino todos) los fiscales no suelen ver las grabaciones en gesell sino que leen directamente los informes psicodiagnósticos que elabora cada terapeuta, producto de las 6 a 8 sesiones que consta la entrevista.

Como dijimos anteriormente, cuando los niños o niñas ingresan a la institución con una denuncia de por medio o hay sospecha de abuso la entrevista va direccionada allí, el relato será conducido hacia ese punto para lograr la descripción de los hechos. El niño/a o adolescente es puesto directamente en el lugar de víctima, si bien la entrevista 
está pensada para que lo cuenten con sus propios ritmos y recursos, es observable como el diálogo va directo al relato del episodio abusivo por el cual están allí. El cuerpo es codificado como un mapa donde hay que marcar o delimitar el delito, los daños. Cuando la cámara fue pensada en sus inicios no contempló más de una dinámica para el contar. El cuerpo se transforma en prueba y cuando el cuerpo no habla o no registra huellas de violencia es la palabra quien "debiera" acudir: el relato es convertido en prueba de que hay daño en ese cuerpo y en esa psiquis.

Hay que producir información para la causa, pero no cualquier tipo de información, lo anecdótico debe ser codificado en clave de información y dato, el quiebre o ese suceso que hizo que se encuentren allí en ese momento no puede ser contado de cualquier manera. Y es que la verdadera lucha es por la forma de contar "el suceso", la verdadera disputa de sentido se da en el terreno de la comunicación (Martín Barbero). En esa traducción de lo que sucedió: ¿Fue un delito, fue un juego, fue un sueño, una fabulación? En esa práctica del codificar/traducir lo que sucedió, se encuentra la bisagra para ver la disputa real por el sentido del hecho. Fue un abuso, una violación, un juego, un manoseo, ¿"nada más"?, pregunta el abogado defensor desconfiado. El "tocar" aquí en estas cuatro paredes de la cámara adquiere un sentido de vejación y violencia muy fuerte, en cambio, frente a un juez el "me tocó" debe ser detallado con precisión, acompañado de tiempo y espacio, personajes, un malo y un inocente. Eso tan intangible como el "me tocó" dicho en boca de cualquiera de las víctimas por falta de palabras debe ser (y lo es) exprimido por las profesionales hasta el punto de lograr (a veces) más palabras, más detalle. Y es que hay un informe que entregar, un hecho que codificar en términos de delito y demostrarlo. Esta primera mediación que no puede ser hecha por cualquiera sino por profesionales de la salud (psicólogas) reciben allí una primera crítica: ¿Acaso sólo ustedes pueden leer y entender a este niño o niña? ¿Acaso sólo ustedes son las únicas autorizadas a decodificar lo que dice este niño/a presuntamente abusado/a? Y es que cuando el cuerpo no habla, si no hay marcas o rastros de material genético es relato contra relato, la acusación de fabulador/a del niño/a de por medio contra un/a adulto/a coherente, racional, calculador. Relato del horror contra un relato difamador y una acusación cruzada hacia el o la adulta protectora. 
Los tiempos, el escenario y los elementos que intervienen en esta situación comunicativa son artificiales, montados para la ocasión, fueron pensados y planificados para recrear un escenario "natural" de conversación que dure poco menos de una hora, con colores, mobiliario y juguetes, que esté siendo grabada y registrada mediante anotaciones de la terapeuta. Las preguntas sobre determinados hechos y personajes fuerzan las dinámicas comunicativas de los agentes y empujan hacia ciertos temas.

¿Dónde quedan todos los relatos que escapan a la lógica víctimo-céntrica? ¿Y los relatos espontáneos? ¿Hay relatos que van por fuera del dolor y la vergüenza? ¿Puede la justicia pensarse por fuera de esta lógica?

Si bien esta escena es pensada en términos de artificialidad, las personas que intervienen en ella no lo son. Todo lo que provoca el interior de la cámara gesell es real, la compasión, el dolor, la impotencia, el odio, el llanto, toda emoción manifestada allí dentro es real. Como vimos anteriormente, el comportamiento del cuerpo en la cámara debe ser medido, sobre todo por parte de la terapeuta para que esa evaluación no sea impugnada como prueba. Al principio de esta investigación la dimensión corporal en determinadas situaciones no fue considerada crucial, con el pasar del tiempo entendimos que para la justicia o los organismos que intervienen a través de ella ponen casi toda su atención en esas manifestaciones corporales. Ante el quiebre del lenguaje el cuerpo habla, se manifiesta y en este manifestarse está la mirada atenta de las profesionales para detectar qué significan y qué está pasando (pesadillas, cuando moja la cama aún cuando ya están en edad de no hacerlo, depresión, llantos, actitudes no correspondientes a su edad sexual, entre otras).

En agosto del 2015 el Tribunal oral en lo Criminal NRO. 17 de la Capital Federal se expidió sobre el juicio por la custodia de las dos hijas de una de las madres protectoras que trabaja en sintonía con nuestro grupo de ayuda de pares. El pedido de custodia total de las hijas se da en el marco de una denuncia penal y civil por abuso sexual agravada por el vínculo que realiza la madre hará unos años contra el progenitor de las niñas. "Poder Judicial de la Nación, Tribunal oral en lo Criminal NRO. 17 de la Capital Federal por F.C, de cuyos ojos no vimos brotar siquiera una lágrima mientras contaba los horripilantes abusos que, según ella B. le había practicado a su hija”, rezaba el fallo del Juez en la causa. Tan sólo un ejemplo de cuanto pesan las manifestaciones corporales en determinadas situaciones. 
Las mediaciones y mediatizaciones que aparecen van a jugar un rol fundamental en el entramado ya que toda la situación comunicativa va a ser registrada por un dispositivo creado para tal fin mediante la grabación de imágenes y sonido y su posterior back up a cds para el uso práctico (o intervención judicial) de la ONG. Son aproximadamente ocho horas por caso -cada evaluación consta de ocho o seis encuentros- tenemos el dato de que ninguna de las entrevistas fue revisada, todos los procedimientos judiciales se basaron en la lectura de la EP de cada profesional. Si bien el soporte material varía, una (EP) se basa siempre en el otro (entrevista en la cámara). En el informe escrito la huella disciplinar y sus interlocutores están muy presentes, cada parte es elaborada con rigurosidad disciplinar para la posterior lectura de las partes. La huella disciplinar en los informes busca lograr legitimidad en lo que sostienen, marcando no solo pertinencia sino terreno en el estudio (histórico) de la psiquis. A diferencia de las grabaciones donde la terapeuta se hace presente en cuerpo y discurso con interlocutores que los tiene enfrente y donde el discurso disciplinar más rígido quizás, más técnico se encuentra desdibujado, será en la escritura del informe que aparecerá la fuerza disciplinar.

Así la segunda codificación que aparece es a través de la disciplina -el diagnóstico aparece con mucha fuerza marcando casi a fuego como una identidad- la evaluación psicodiagnóstica definida por las propias profesionales como un cuadro de como se encuentra el niño o niña hasta ese momento, se convierte en la hoja de ruta de esa profesional. Una hoja de ruta que buscará que los otros profesionales que intervienen en el proceso legal lo sigan lo más ajustadamente posible. A continuación veremos cómo es que confeccionan esa hoja de ruta de esa situación comunicativa: 


\section{¿Cuántas traducciones sufre el relato de experiencia traumática?}

Lo amorfo, sin forma, límites o fronteras, inconsistente, ajeno, difuso y confuso debe ser codificado en un lenguaje articulado, no solo eso sino que debe cumplir con los estándares institucionales y marcos regulatorios específicos que obligan para llegar a su utilización y comprensión por parte de distintos organismos como la Justicia. Entonces, la primera codificación/traducción que sufre la experiencia traumática es su transformación en relato, esto es: ¿Cómo cuentan la experiencia traumática?

"Lo hacía cuando mi mamá no estaba o estaba durmiendo, él me decía que íbamos a comprar y yo fui a comprar pensando que era verdad y me llevó a un campo y yo le dije a donde me llevaba y me dijo vamos hasta ahí y volvemos y después me dijo sacate la ropa, no quiero le decía yo, y me agarro y me sacó la ropa, era un día de lluvia, estaba lloviendo y me sacó la ropa y yo gritaba y nadie me escuchaba y encontró un cable tirado y me pegaba y le pedía por favor que no me haga nada, me quedaron las marcas y me dijo que no le diga nada a mi mamá y que me ponga algo de mangas largas, me había pegado en las piernas y en los brazos." (EP de Mikaela, pp. 6-7)

Mikaela tenía 15 años cuando, sin perder mucho tiempo, relató esto a la psicóloga de la ONG en el 2013, hasta ese momento su padrastro y abusador estaba prófugo con pedido de captura por el secuestro y desaparición de su hermana menor de 6 años. Si bien hay huellas discursivas, rasgos que denotan que la experiencia ya fuera enunciada en otro momento ${ }^{34}$, hay dificultades e impedimentos internos para contarla (nuevamente). Estas huellas tienen que ver con la utilización de palabras específicas que provienen de otras esferas sociales como el derecho, la medicina forense o el policial. El uso de ciertas palabras en relatos de niños, niñas y/o jóvenes como ser "vagina", "me abusó", "pene", "me violó" nos llama la atención por lo desconectado que se oye con respecto al resto de la estructura del relato mas aniñado, si me permiten el término... el relato de alguien que nunca ha atravesado la experiencia de testimoniar antes es bien

\footnotetext{
${ }^{34}$ Nos referimos a que ya hubo una oportunidad anterior en la que contaron lo sucedido. Suele ocurrir cuando él o la abusadora ya cuentan con una denuncia previa a este abuso y los niños/as prestaron testimonio anteriormente ante otros organismos e instituciones.
} 
particular, algo más amorfo, incomprensible para el oído desentrenado, donde abundan las metáforas y las descripciones confusas. Mikaela ya había atravesado por la experiencia del contar sobre lo que le hizo su padrastro ante otros organismos y es así que, en determinadas situaciones, ya sabía qué hacer.

Como decíamos, esta primera codificación de la experiencia siempre es sensible de ser "pulida" por las terapeutas de la ONG a los fines de beneficiar a las víctimas de este proceso. Hay ocasiones en que el relato se vuelve muy oscuro e inimaginable, son descripciones que la terapeuta no puede ubicar o representar(se) en imágenes porque no cuenta con ellas en su imaginario, quizás. He allí el desconcierto de la terapeuta cuando Andrea le narra cómo su progenitora (mujer) abusaba de ella, su hermano varón y sus hermanitas. La directora de la ONG solía decir que es corriente confundir o disfrazar de amor maternal un abuso, que las fronteras para ellas (las terapeutas) son bastante claras pero para gran parte de esta sociedad que ubica a la figura de la madre como santa, pulcra, intachable, es inimaginable asociarla a una abusadora de sus propios hijos/as. Aún así y con todo el bagaje disciplinar encima, cuando Andrea detalló cómo específicamente su madre abusaba de su hermano varón la psicóloga parecía no entender lo que la niña trataba de contarle. Incluso en esta segunda codificación de la profesional sobre el relato de la niña le cuesta encontrar las imágenes adecuadas para registrar en sus notas. Notas que deben ser volcadas al informe presentado a la coordinación.

El objetivo que tienen como organización es que la documentación que es producida en el marco de las evaluaciones sean lo más claras y legibles posible para favorecer a ese niño o niña que -dicho sea de paso- la violencia que ejercieron contra él o ella ya fue comprobada en términos disciplinares de la psicología. El punto es demostrar, dentro de las lógicas de los organismos que se encargan de velar por sus seguridades, que ese relato tiene que ser tenido en cuenta para actuar a favor de los y las víctimas. Entonces, de pronto nos encontramos con datos "curiosos" en los informes escritos de evaluación que contribuirán a dar credibilidad a ese niño o niña frente a una causa, pero antes esto y citando a Bajtín (1998): la comprensión o diálogo de la situación comunicativa o escenario en el que se encuentra el niño/a permite su primera articulación, codificación y enunciación del relato sobre experiencia traumática. Esta situación o escena va a determinar qué cuentan y cómo lo cuentan, va a fraccionar el tiempo del continuum (esto es no más de una hora reloj), qué se puede (y no) realizar 
dentro del dispositivo como parte del relato, por dar un ejemplo, si alguna de las terapeutas quiere o siente que debe abrazar a la persona que tiene delante porque se quebró o llora debe antes apagar la cámara que registra todo lo que sucede en consultorio. Por política de la organización ese gesto de acercamiento no debe quedar registrado, recordemos que tanto los fiscales como abogados y juez/a pueden tener acceso a los mismos con solo una orden. Por supuesto que estas fronteras no son tan rigurosas y hay "conflictos" y contradicciones con estas normativas todo el tiempo.

Pero volvamos a lo que sosteníamos, parte de este pulir el relato por parte de las terapeutas tiene que ver con encauzarlo, darle forma y fronteras, si aquello primero dicho fue incomprensible para la terapeuta hay que repreguntar, si aquello dicho primero puede contribuir a la causa hay que detenerse allí y raspar, si lo dicho primero cuenta con tanta intensidad emocional hay que traducirlo en clave disciplinar: El Trauma.

"Hasta aquí se puede concluir en el relato de Mikaela que es confiable, verídico, consistente, preciso y sin lagunas. Presenta una estructura lógica contextualizada respecto del tiempo y espacio en el que sucedieron los hechos. No se observan signos de mendicidad, sugestionabilidad, ni fabulación.” (EP de Mikaela, p. 9)

Estamos aquí ante la segunda codificación y transformación que sufre la experiencia del abuso sexual: la codificación en clave disciplinar. De lo oral hacia la libreta de anotaciones de la terapeuta a la evaluación psicodiagnóstica entregada a la coordinación de la ONG y de allí la elevan (en este caso) a la Fiscalía General y al Centro de Asistencia a la Víctima - Departamento Judicial... con semejante recorrido institucional el informe no puede ser escrito de cualquier forma: su formato es la Evaluación Psicodiagnóstica (EP). La EP consta de varias partes que varían en longitud y profundidad según cada profesional, en este caso la ONG posee un formato elaborado por ellas, que deben cumplir para su posterior elevación. 
1. Identificación.

Datos de filiación de la profesional: (Quién es la profesional a cargo y su formación en la materia).

Datos de filiación del evaluado: (Datos de la niña, niño o joven).

Procedencia del caso: (Quién solicitó el informe. En el caso de Mikaela fue el Departamento Judicial).

2. Objetivos del Informe: (Los fines de realizar una EP).

3. Metodología

Entrevistas y pruebas complementarias: "El análisis psicológico profundo del discurso del paciente es el objetivo de la entrevista psicodiagnóstica, esta permite a través de preguntas semidirigidas y una escucha psicológica inferir sobre aspectos de la dinámica del entrevistado."

4. Análisis descriptivo y/o exploración psicológica: (Cómo se encuentra la persona a ese momento de la EP).

5. Resultados: (La presentación de los indicadores que "detectó" la terapeuta, esto es, indicadores de abuso sexual).

6. Conclusiones: (La construcción de esos indicadores a la luz de la bibliografía de la disciplina).

7. Recomendaciones: (La profesional, a partir de las observaciones que hace, recomienda al juzgado cómo actuar de ahora en más).

8. Bibliografía

\section{Modelo de EP. que utiliza la ONG.}

Como vemos, el relato una vez convertido en dato y volcado a este formato de informe debe contener determinada información sobre Mikaela (y todos/as los/as que atraviesan una EP) para que sea tenido en cuenta durante el proceso judicial. ¿Únicamente la experiencia del abuso codifican? ¿Qué es lo que interesa de la totalidad del relato descriptivo? ¿Necesitan algo más para volver fiable a este relato que devino en testimonio? 
“[...] actitud que fue cambiando hacia el segundo encuentro mostrándose luego muy bien predispuesta respecto a la evaluación psicodiagnóstica a realizar. De buen estado de ánimo, algunas veces cansada y con sueño porque se acuesta muy tarde debido a las dificultades que presenta para dormir, se maneja con corrección y buenos modales, logra establecer un buen y fluido vínculo con su interlocutor. Logra adecuarse al marco establecido, comprendiendo las consignas que se le imparten en relación a las actividades propuestas y pudiendo sostener el ritmo de trabajo de las mismas, si surgen dudas, pregunta. Se expresa con corrección y riqueza en su vocabulario, de esta manera brinda la información pertinente para la elaboración del diagnóstico." (EP de Mikaela, pp. 5-6)

Entonces, no solo la experiencia en relación al abuso y la violencia deben ser traducidas en un formato adecuado a la institución sino también el comportamiento de ese niño o niña al interior del consultorio. Bien lo dijo la coordinadora de la ONG en varias ocasiones al equipo de terapeutas, ningún fiscal o juez mira los videos de Gesell, es por ello que los informes deben ser lo más detallados y descriptivos posibles. Debe ser presentada una persona que no miente, ni fabula... ¿Cómo debería actuar una persona que miente o fabula?

"Se encuentra siempre aseada, adecuada y prolijamente vestida" y luego “presenta una estructura lógica, contextualizada respecto del tiempo y del espacio en el que sucedieron los hechos. No se observan signos de mendicidad, sugestionabilidad, ni fabulación" (p. 8 de la EP). A partir de estas aclaraciones de la terapeuta obliga preguntarnos: ¿Cómo es leído un niño con características de mendicidad, abandono y rechazo en estas tramas discursivas? ¿Qué valores se están jugando en la presentación de una persona con estas características?

Estas características son convertidas en información para el informe, son puestas en valor y tienen su correlato en el discurso disciplinar. "Presenta una estructura lógica contextualizada en tiempo y espacio en que se sucedieron los hechos" significa la capacidad de Mikaela de registrar el daño, ubicarlo en una línea temporal y espacial y compartirlo con la profesional. Esto acompañado de su bibliografía pertinente, clara y descriptiva, comunicable a un destinatario que no es del mismo campo disciplinar pero acude a sus herramientas para solucionar un conflicto. 
Los nombres, lugares y fechas fueron modificados para preservar a los/as sujetos que intervienen en esta investigación.

Se tomaron para el análisis de esta primera situación comunicativa las ocho sesiones (que es el acceso reglamentario de la institución) que se corresponden con cada uno de los casos, la entrega y selección de los mismos fue hecha por la misma dirección de la ONG a los fines de esta investigación. El criterio de selección de los casos estuvo estrictamente a merced de la dirección y coordinación, una vez presentados los objetivos de esta tesis la dirección seleccionó sin dejar de destacar lo interesantes que resultaban para su análisis. Elementos interesantes vistos desde la psicología, por un lado, y para nosotras desde la comunicación.

Los casos son: el abuso y violencia a tres hermanas/o (Andrea 10 años, Daniel 14 años, Ana 3 años y María de 6 años) por parte de sus progenitores, una adolescente (Micaela 16 años) víctima de su progenitor y una niña (Martina 4 años) víctima del esposo de su abuela. El total en cámara gesell son de treinta (30) horas que se corresponden con cinco (5) casos, en el caso de Mikaela no contamos con la totalidad de las sesiones puesto que la causa fue interrumpida por el secuestro de la hermana más chica por parte del padrastro. Cada caso cuenta con su correspondiente documentación, esto es: grabaciones de las sesiones en gesell, evaluación psicodiagnóstica hecha por cada profesional al finalizar los encuentros y denuncias o pedidos de peritaje por parte del juzgado.

Por razones éticas y de confidencialidad es que decidimos no adjuntar documentación anexa alguna a la tesis, desgrabaciones completas o imágenes que puedan ayudar a identificar a las personas que intervienen. Tales materiales se encuentran bajo mi tutela y no fueron vistos u oído por nadie más, esto es en mutuo acuerdo (firma de Consentimiento Informado y contrato de por medio) con la organización y su estricto cuidado para con los niños y niñas y en sintonía también con organismos y protocolos internacionales que velan por el cuidado de esta población. Los y las lectoras sabrán entender la gravedad de los casos y el cuidado que merecen a la hora de trabajarlos. 


\begin{abstract}
Andrea
Andrea ingresa al consultorio y se sienta a esperar que llegue la terapeuta. La ONG entrena a su propio personal de salud en el tratamiento del abuso sexual en la infancia en determinadas edades. Es así que la Dirección y la Coordinación, de acuerdo a las características del caso de Andrea asignó a la Psic. R. para su evaluación. R. es especialista en niños y niñas de la edad de Andrea, hasta 11 años.

Andrea tiene 10 años y dos hermanas más chicas (Ana de 3 años y María de 6 años) y un hermano más grande (Daniel de 14 años) al momento de iniciar las sesiones. Los/as cuatro hermanos/as eran abusados sexualmente por sus progenitores y maltratados con diversas palizas y castigos, estos son golpes, torturas, grandes períodos de ayuno, golpizas seguidas de ducha helada en invierno y otras vejaciones. Gracias a la abuela paterna pudieron hacer la denuncia contra los padres y la abuela paterna logra la custodia de los/as hermanos/as. La evaluación psicodiagnóstica a los cuatro hermanos/as fue solicitada por el fiscal de la causa que intervino y el tratamiento psicológico fue solicitado por la misma abuela. Los/as hermanos/as fueron atendidos/as en simultáneo por distintas profesionales de la institución llevando a cabo todas las sesiones y entrega de la documentación al fiscal. La causa se cierra cuando ambos progenitores fueron acribillados por dos personas desconocidas que iban a alta velocidad en motocicleta una noche por el frente de la casa. Los medios atribuyeron el asesinato a negociados con la droga.
\end{abstract}


La psicóloga ingresa a la cámara gesell hecha consultorio ambientado y las cámaras listas para grabar.

Psicóloga -Hola Andrea, ¿cómo estás? ¡Qué lindo nombre es Andrea! (Andrea, encogida en su asiento, observa toda la habitación. Los baúles con juguetes, el gran espejo, las mesitas y de vuelta a la cara de la psicóloga)

Psicóloga -¿Sabés porqué estás acá Andrea?

Andrea -Yo sé que acá me tienen que atender porque pasé muchas cosas feas. Creo que para que yo diga todo (fue la respuesta de la niña de 10 años)

Psicóloga -Es así, la idea acá es ayudarlos y que yo pueda saber qué es lo que te está pasando. ¿Qué es lo que esperás de acá?

Andrea -Espero que me atiendan y poder decir todo. Yo acá estoy mejor que antes. $N$. me tocaba y yo sufrí un poco... y mucho. Espero poder decir todo.

Este "decir todo" se refería a contar eso disruptivo que le sucedió, con las sesiones veremos cómo Andrea vomita cada recuerdo, cada vivencia en relación a la violencia que ejercían no sólo sus progenitores sobre ella y sus hermanitas/o sino también amigos varones adultos del padre. Andrea al momento de empezar con las sesiones era plenamente consciente que debía contar todo lo que sabía y sentía, todo lo que recordaba y por todo lo que vivió durante años para "salvar" a ella y a sus hermanas.

Psicóloga -¿Cuál es la idea? Nosotras nos vamos a ver ocho veces y la idea va a ser que yo pueda saber qué es lo que te está pasando. La idea es que te sientas cómoda. Vamos a jugar, a dibujar, a contar historias así yo puedo saber qué es lo que te está pasando, ¿sabés? 
Antes del minuto 8 de la primera sesión Andrea pudo enunciar parte de lo que era vivir con sus padres, a los cuales jamás durante las ocho sesiones los llamó como papá o mamá, sino por sus respectivos nombres de pila: "es porque (si) digo papá y mamá me pone mal (lagrimea). Una mamá haría algo, lo denunciaría, haría algo, lucharía... N. (progenitor) me tocó y todo eso y un papá no hace eso, un papá cuida a los chicos, no los maltrata." Es tan fuerte la palabra, es tan doloroso el recuerdo que encarna en palabra, es de la historia de quien se protege, del recuerdo, debe nombrarlo por otro nombre, reconocerlo como diferente para seguir contando, narrando. Son estrategias discursivas: "mi hermanita María, la de dos años, tres...a N. (progenitor) le dice Cuco. Ella le tiene miedo, a ella le tocaba también (...) la ponía arriba del cuerpo de él y la tocaba (...)." Ellas vuelven a vivir a través del relato y ese relato es tan doloroso que deben volver "soportable" el dolor (Feld, 2002) para seguir contando, para seguir viviendo.

Psicóloga -¿Quién te pegaba más?

Andrea - N. (su progenitor). No me gusta mucho, una cosa es que te peguen para educar, a mi hermana María le pegan también y ella es muy chiquitita. Tenía un año y ya le pegaban.

Si bien las evaluaciones psicodiagnósticas que realizan en la ONG no fueron pensadas en un principio para sacar el relato del abuso, si hay sospechas de por medio o una denuncia ante conocimiento previo de una situación violenta vivida por el niño o niña la entrevista indefectiblemente irá por ahí. En el caso de Andrea, las autoridades tenían conocimiento previo de que algo había sucedido con los/as cuatro hermanos/as, así la entrevista se dirigió hacia ese lugar sin mayores problemas. Como dijimos, Andrea sabía que debía "contar todo" por el bien de ella y sus hermanas/o.

A la segunda sesión llegó ansiosa de contar, durante todas las sesiones se mostró encogida en su silla:

Andrea -¿Qué más me olvidé de contar? yo sé algo que me olvidé de contarle... (murmura por lo bajo) 
Y es que eso "que le pasó" es la disrupción, es el punto de quiebre de por qué debe asistir a esas entrevistas con una persona que en principio no conoce y le está pidiendo que le cuente una serie de eventos. El inicio de la entrevista siempre es sobre cualquier otro tema cuando de niños y niñas se trata, en el caso de Andrea el "contar" apareció ya en el primer encuentro, los abusos eran tan cotidianos y brutales que no tardó mucho en compartirlos.

El equipo considera una entrevista "exitosa" a aquella en la que aparece efectivamente el relato de violencia y abuso para su posterior registro escrito en las evaluaciones, en algunos casos no aparece en ninguna de las sesiones y las terapeutas deben basarse en los distintos test que disponen (Persona Bajo la Lluvia, HTP, Cuestionario Desiderativo, test de Bender) para dar cuenta del daño. Si la entrevista está difícil o parada las terapeutas acuden a los dibujos y juegos con el niño o niña... y he aquí uno de los reproches por parte del fiscal que interviene en la causa: ¿son las únicas que pueden interpretar lo que el niño/a quiere decir? Si no hay un relato articulado, preciso donde el delito pueda ser leído y comprendido, presentan test y evaluaciones para identificar el abuso. De los mismos nos ocuparemos en el apartado siguiente.

Como dijimos, Andrea sabía que debía contar todo, una serie de sucesos fue enumerando la niña a medida que pasaban las horas y las sesiones que ni hizo falta hacer preguntas específicas. La confusión de la terapeuta apareció cuando la niña contó situaciones difíciles de comprender desde el raciocinio, escenas inimaginables para una mente desentrenada. Y es que ante el relato de una experiencia traumática pareciera que faltan las palabras para describir y para el contar y para quien escucha, faltan las imágenes para representar(nos) esa situación abusiva. En la segunda sesión, en su segundo encuentro con la terapeuta Andrea contó cómo su progenitora abusaba sexualmente de su hermano varón y de las tres. La descripción de la escena era incomprensible tanto por la terapeuta como por mí al momento de ver las grabaciones. $\mathrm{Y}$ es que en el imaginario social casi no aparece la figura de la mujer/madre/progenitora abusadora, ¿cómo viola una mujer a su hijo? Estos interrogantes aparecen al momento de escuchar como la niña describe una de las muchas formas en que su madre abusaba de su hermano. Esa incapacidad de acomodar o de representar en la cabeza aquello que estamos escuchando aparece como un obstáculo en la comprensión de la descripción, "¿cómo que se apretaba el pezón?", pregunta asombrada la terapeuta. La niña esforzándose por hacerse entender le explica lo obvio: lo tocaba a mi hermano. ¿Cómo 
diferenciamos un "cariño" maternal del abuso y el acoso sexual? ¿Cuáles son las fronteras y los límites para que sea considerado delito? Esta traducción incompleta de lo que la niña estaba narrando hay que ahondar $y$ es que en las evaluaciones psicodiagnósticas debe quedar lo más claro posible -para quien lo lea- que esa madre está dañando a ese joven, el lenguaje debe ser claro, descriptivo, posible de ser imaginado por el fiscal. Allí, de frente y mediada tecnológicamente, caí en la cuenta de que el primer problema comunicacional con el que nos encontramos aquellos que investigamos en estas aguas es el problema de la representación de aquello que se dice. ¿Cómo investigar comunicacionalmente aquello incomprensible, inimaginable, inaprensible, incapaz de ser etiquetado y ubicado en algún que otro casillero lingüístico? Comunicacionalmente allí había un problema entre lo que Andrea intentaba explicar y lo que nosotras (en diferentes tiempos, espacios y objetivos) intentábamos entender. Tuve que ir a libros de ficción, películas y relatos de adultos/as que atravesaron un abuso sexual con victimarias mujeres, necesitaba insumos representativos que me ayuden a imaginar aquello que estaba siendo dicho y se mostraba como incapaz de ser compartido. Y es que el problema no es qué se dice, sino cómo se dice en determinada situación comunicativa (tiempo y espacio)... que no es real/natural, que sucede en un tiempo y un espacio distinto al tiempo y espacio de lo que está siendo narrado. El problema no fue nuestra incapacidad de representarnos aquello que estaba siendo dicho, sino nuestra incomodidad de no poder etiquetar aquello "otro" que estaba siendo contado, no soportamos o no resistimos escuchar aquello que no puede ser etiquetado por los estándares de nuestras disciplinas: ella para su evaluación, yo para mis análisis. Sobre este caso, tiempo después la terapeuta me confesó que le costó mucho escribir el informe del caso de Andrea. "No podía entender lo que me estaba diciendo."

Con el tiempo entendí o aprendí a preguntarme ¿por qué esta incomodidad de desconocer en qué casillero ubicar(nos)? Y es que lo que no se nombra no existe, dicen estudiosos de la comunicación, pero lo que se nombra se mata, responden desde las teorías de género. Entonces, lo experiencial cobra fuerza y se impone a las palabras, ella lo vivió y lo sufrió, está allí aunque no pueda ser nombrado, aunque no existan las palabras en el bagaje de esa niña para compartir esa experiencia. ¡Qué gran desafío el de esa terapeuta! Escribir y codificar en un documento legible todo esto que no puede ser dicho. No todo. 
La terapeuta jamás registró nada durante las sesiones, todas sus anotaciones para la causa fueron posteriores a despedir a Andrea.

\section{Martina}

Martina tiene 4 años al momento de la entrevista. Sin leer la documentación extra del caso y con solo ver las grabaciones en cámara se puede deducir, ante la insistencia de la terapeuta con un dato, que su abuso fue cometido en el entorno de una de sus dos abuelas.

Psicóloga -Y de tu abuela Carmen nunca me hablas.

Martina -Porque me da vergüenza...

(Esta fue la segunda vez que Martina habló de su abuela y fue en la sesión número cinco. La primera vez que habló de su abuela Carmen fue durante el tercer encuentro con la terapeuta y fue igual de escueta)

Psicóloga -¿Por qué no vas a verla a tu otra abuela?

Martina -Porque no me conoce.

Nunca en sus ocho sesiones Martina habló concretamente sobre su abuso, la única referencia que hizo fue en la sesión número tres, durante un juego con muñecas que las hacían hablar, la muñeca de la psicóloga pregunta "¿Con quién vive tu abuela?", Martina no contesta. Siguen jugando. Vuelve a preguntar por la abuela y agrega: 
Psicóloga -No me hablás nunca de tu otra abuela ¿por qué no vas a verla?

Martina -Porque no me conoce.

Psicóloga -¡Cómo que no te conoce! Yo creo que si te conoce.

Martina -Yo no la conozco a Carmen. Cuando era más pequeña sí.

Psicóloga -¿Vos no tenés ganas de verla?

Martina -No.

Psicóloga -¿Por qué no?

Martina -Porque Juan que es el esposo de Carmen me molesta. (Lo dice muy enojada y entre dientes).

Psicóloga -Juan el esposo de Carmen te molesta. ¿Y qué te dice?

Martina -Me dice que los chupetines son chupetes. ¡Y yo no quiero! ¡Me molesta!

Psicóloga -¿Me querés contar qué te hace? (Martina niega con la cabeza)

Psicóloga - Yo te puedo ayudar.

(Silencio)

Psicóloga -¿Qué chupetines son chupetes?

Martina -El que él... el chupetín... el que se...el que se muerde.

Psicóloga -¿Y dónde está ese chupetín? ¿Quién lo tiene?

Martina -Más allá... (Hace una seña con la mano como indicando distancia). 
Esta fue toda la referencia que hizo Martina sobre su abusador. La terapeuta trata de estirar la única punta del ovillo de lana que la niña le ofrece, la única pista que se presenta a lo largo de las sesiones la terapeuta busca ahondar, raspar y tratar de captar lugares, tiempos, imágenes.

Psicóloga - ¿Y qué más te hace Juan?

Martina -Me molestaba un poquito.

Psicóloga - ¿Y vos estabas sola con él?

Martina -Carmen mi abuela se iba a comprar.

Psicóloga -¿Y ahí qué pasó?

(Silencio)

Psicóloga -¿Cuándo te molestó Juan?

Martina -Un día cuando yo era pequeña.

Psicóloga - ¿Y vos estabas sola con él? (Insiste)

Martina -No.

Psicóloga -¿Con quién estabas?

Martina -Nadie más.

Una vez más trata de direccionar la entrevista hacia Juan y ese episodio que menciona Martina. Inútilmente, Martina ha decidido no hablar más y sigue en su juego. Hay un silencio pesado en la habitación. La terapeuta anota los pequeños logros de ese día. 
Todos los encuentros fueron así, la hora o 45 minutos la pasaban jugando, Martina hizo muy pocas referencias a su cotidianidad, sólo hablaba del juego que estaban desarrollando en ese momento. Tras varios intentos de que Martina hable de su abuso, la terapeuta en el encuentro número cinco decide leerle un cuento, la identificación con uno de los personajes parecía ser la estrategia para empujar el relato de la niña:

(La terapeuta toma un librito del baúl de juguetes y lee sobre la mesa)

Psicóloga -No hay nada más lindo que sentir amor y demostrarlo con abrazos y mimos y besos (Martina se ríe). Es hermoso que dos personas que se quieren mucho se abracen, se besen y se mimen pero te puede pasar que no te gusta que una persona que conocés y querés quiera besarte, abrazarte o tocarte o pedir que vos lo hagas...entonces, tenés qué decirle: 'no quiero tocarte ni que me toques'. Lo mismo podés sentir cuando una persona desconocida quiere besarte, abrazarte y tocarte o pedirte que vos se lo hagas. Si no te gusta y te parece mal decile: no quiero tocarte ni que me toques. Si el abrazo te parece monstruoso decí bien fuerte: ¡No lo hagas! Si esa persona es buena te va a escuchar y te va a dejar tranquilo, puede ser que se enoje mucho y te asuste gritando fuerte si no le hacés caso. O que, sin enojarse, siga tocándote.

Las cosquillas en los juegos pueden ser muy divertidas, pero cuando el juego no te gusta o la persona te hace sentir mal con las cosquillas no te dejes confundir, decile bien fuerte: ¡No lo hagas! Aunque te de vergüenza contáselo a cualquier persona grande en quien confíes, si las cosas no salen bien algunos chicos sienten que tienen toda la culpa por haber hecho las cosas al revés o podés sentir que te metiste en un lio enorme, imposible de arreglar. Hasta podés sentir que tenés ganas de irte a otro lugar o que nada tiene ya importancia o que nadie te va a querer. Quizás te da miedo contarlo porque te dicen que si lo contás algo malo puede pasarte a vos o a la gente que más querés. No le creas a esa persona, incluso si no te sentiste mal, ni te dio miedo contalo igual: contáselo a tus padres, a tus tías, a tu abuela, a tu maestra o a tu doctor, contale que alguien va a escucharte y creerte si lo decís bien bien fuerte, no te sientas atrapado ni solo. Todos los chicos y las chicas merecen ser queridos, respetados y tratados bien. Vos también. 
No hay nada más lindo que sentir amor y demostrarlo con abrazos, mimos y besos....pensemos, ¿alguna vez te pasó algo parecido... cómo el cuento? ¿Alguna vez te pasó algo así?

(Silencio. Martina se sonríe y niega con la cabeza. Sigue con su juego con muñecas)

Vale mencionar que este cuento y otros similares fueron confeccionados por las mismas profesionales de la ONG para niños y niñas de la edad de Martina. Tan pequeños/as son que fue necesario idear otras estrategias comunicacionales para acceder a sus experiencias dolorosas. No fue el caso de Martina.

Psicóloga -¿Te gustó el cuento? Sí. Bueno....

(Silencio. Martina retoma el diálogo hablando del juego)

Durante todas las sesiones casi no hay palabras entre la terapeuta y Martina. Las únicas referencias que aparecen son las preguntas que realiza la profesional y las escuetas respuestas de Martina, por supuesto, ella elige en todo momento qué responder y qué no. Tanto es así que ante la pregunta por el esposo de la abuela se muestra visiblemente molesta y negada a responder más de la cuenta. Durante todos los encuentros con la profesional jugaron, hablaron de muñecas y los diálogos siempre fueron en referencia a lo que estaban jugando. Martina no dio datos de su vida por fuera del juego, de su cotidianidad ni muchas más precisiones sobre su familia, amigas u otros. Todo el dato que poseía la profesional y con la cual nutría a sus inquietudes fue a través de otras voces como los padres y maestras de la niña. ¿Cómo codificar esa experiencia si no hay palabras? ¿Cómo se transforma en dato el resultado de un test? ¿Cómo se lo transforma en material sensible de ser leído por otras disciplinas?

Una vez más todo el dispositivo de cámara gesell está ideado para las palabras, para los relatos articulados y coherentes, que si bien está contemplado y las terapeutas están preparadas para casos como estos la insistencia en preguntar sobre el acusado en cuestión pone de manifiesto que la única "salida" es lograr que la niña cuente qué le hizo Juan. ¿Y todo lo que queda por fuera del relato oral? Pareciera que esta situación comunicativa no resiste otros soportes materiales de sentido. ¿Qué es lo que está en 
juego aquí? ¿La veracidad del no relato, el sentido de los test y los juegos? ¿Cómo transformar en utilitario todo lo que generan dentro de la cámara? ¿Sabe la Justicia leer en estos términos y con estos tiempos? Y qué pasaría con todo lo que sucede por fuera del abuso concreto, de qué otras maneras se puede violar o violentar a una niña tan chiquita. La Justicia y sus profesionales ¿están preparados para contemplar un relato sobre experiencia traumática que no cumpla estrictamente con las formas narrativas tradicionales, esto es, personajes, nudo y desenlace?

Aquí no hubo dudas de que a la niña la hayan lastimado pero había que confeccionar elementos probatorios que lo sostengan, el desafío es: ¿Qué tipo de material creíble, fehaciente son capaces de producir las terapeutas con insumos lingüísticos aparentemente escasos?

La directora de la ONG en varias ocasiones mencionó situaciones en las que las terapeutas están obligadas a levantar el secreto profesional por orden de un juez y son llamadas a declarar como testigos en la causa, ante las declaraciones de la psicóloga la insistente pregunta "¿eso dijo el/la niño/a o es una interpretación suya?" Y es que la psicología como disciplina está parada en esa peligrosa y tramposa cuerda, tensa, entre ser traductoras, codificadoras, intérpretes. Son empíricas por excelencia, siempre debe ser demostrable, mostrable. Los peligrosos pasillos por los que suelen correr a las profesionales son bien objetables pero para un abogado que busca "la prueba" un dibujo y su traducción/interpretación a un abuso sexual pueden resultar muy vagos e inconsistentes.

Dicho así la tarea de declarar parece casi sencillo de resolverse para las psicólogas: contar lo que sé, oí y vi. Pero sentada allí frente al abusador o abusadora, con un fiscal ansioso de que pise el palito, declarar se vuelve una odisea. En la mira está la formación de la profesional y sus años de experiencia... y no cualquier experiencia, debe ser una experiencia profesional comprobable en temas relacionados al abuso sexual. Demás está decir que hay muchos pasillos y recovecos que desconocemos pero si hemos de mencionar a donde van dirigidas las balas es hacia la responsabilidad ética de la profesional. Hay que ser muy cuidadosas de denunciar en el momento justo, de saber sortear la trampa entre el secreto profesional y la obligación de denunciar cuando se trata de un niño, niña o joven menor de edad. Son las trampas del contar para un abogado ansioso de detectar una irregularidad en la presentación de pruebas, la única 
forma de levantar el secreto profesional es por orden de un juez o cuando corre peligro la vida de esa persona, ¿y qué sucede con las evaluaciones psicodiagnósticas que no son denuncia ni peritaje? En varias oportunidades las terapeutas más experimentadas fueron llamadas a realizar peritaje para alguna de las partes (generalmente del adulto protector de ese niño/a para demostrar el abuso del niño/a) pero lo realizan a través de la EP y bajo la tutela de la ONG.

Entonces, ese documento que no fue solicitado por el juez sino que es realizada a cualquier niño, niña o joven que ingrese a la ONG está en un delicado equilibrio entre violatorio al secreto profesional (porque se realiza previo a cualquier pedido) y responsabilidad social y profesional por parte de las profesionales que toman contacto con un caso de delito. Los años y los casos de experiencia le dieron buena muñeca a la dirección para sortear estas trampas que los abogados son muy habilidosos de detectar. Aún así, la directora tiene varias denuncias en su contra por este motivo. De un manotazo airado insiste en que ya se van a cansar de denunciar y que va a seguir trabajando. Hasta el día de hoy la ONG sigue atendiendo con la misma dinámica y es la única especializada en temáticas referidas al abuso sexual en niños, niñas y jóvenes.

La lista de espera para atenderse con ellas supera las 300 personas por semana.

\section{Daniel}

Daniel es el hermano más grande de Andrea, 14 años al momento de la entrevista. Llegó al consultorio algo "familiarizado" con la dinámica a la que se iba a someter. Fue él quien denunció a sus progenitores por los abusos y golpizas a sus hermanas más chicas, "nunca pensaron que él iba a contar" explica Andrea.

"No, la verdad es que no tenía ganas de ir al colegio porque viste me levantaba y no comía porque no tenían nada para comer, como me tenía que cocinar yo, no había nada en la heladera o algo así y tenía que ir al colegio todo así... a veces no me podía bañar porque se tenía que bañar mi papá para despertarse algo así y no sé, no tenía ni ganas de vivir yo...." 
Quizás Daniel con referencias más claras para ser traducidas en un lenguaje codificado comprensible para otras personas por fuera de la psicología explica y detalla lo que siente un niño o niña que está atravesando la experiencia del abuso sexual. Las terapeutas coinciden en la metáfora del "disparo al alma" para hablar de los traumas que deja el incesto, es la muerte en vida de ese niño/a y el panorama hostil para su pronta resolución en términos reparatorios, lo que deprime no solo al niño sino a su entorno protector. Si es que lo tiene.

Daniel tiene más recursos lingüísticos que Martina y Andrea para contarle a la terapeuta cómo vivía por aquellos años, consciente de los daños y de la ilegalidad de los actos de sus progenitores decide denunciar. "A mi papá. Pero tengo que... no sé, no siento nada yo. Lo que pasó con mi abuela capaz sienta algo viste, me trata bien y todas esas boludeces capaz que siento algo pero no... es más, si se mueren mi papá y mi mamá no voy a sentir nada no sé, como si no pasó nada, sigue igual ni me importa.”

Si la narración aparece cuando lo disruptivo emerge como dice Benjamín, ¿qué sucede cuando no hay acontecimiento alguno distinto? Cuando la vida transcurre siempre con la misma dinámica violenta y pesada. ¿Cuándo aparece la experiencia disruptiva si la experiencia cotidiana es siempre igual de dolorosa e invivible? Y si las narrativas son matriz para mediar la experiencia, comprender la otredad (García, 2004), ¿en qué momento aparece eso “otro", lo doloroso, lo amorfo y se vuelve codificable, semiotizable (Voloshinov)? Decimos esto como posibilidad de inscribirse en un proceso de semiotización.

Psicóloga -Bueno, comentame un poquito lo que vos recuerdes o tengas ganas de contar acerca de esto ¿no?

Daniel -Qué... Ehhh....que papá viste, cuando yo tenía....cuando yo era chico todavía mi papá no había salido del penal, pero antes de salir del penal con mi mamá lo veíamos todos los días viste... a visitarlo de vez en cuando porque él estaba en Devoto. Yo me acuerdo de eso, que íbamos a Devoto y cuando íbamos a veces íbamos con mi abuela a llevarle mercadería y todas las cosas, mi mamá a veces le pasaba droga se la metía en la con...se la metía viste, después le llevaba droga adentro del penal y siempre cuando iba tenían relaciones con mamá para eso iba mi mamá, para sacársela porque viste que tiene la carpa ahí en un patio 
hay tipo una carpa ahí. Bueno, se encerraban ahí y teníamos que esperar afuera.

Yo lo saludaba y después cogía con mi mamá.

No había un hecho concreto que contar sino una vida de miserias y abusos. En este caso, Daniel ya había pasado por instancias similares del contar, se deja ver en su relato que selecciona lo que debe contar, se limita a las preguntas de la terapeuta. A diferencia de Martina o en ocasiones con Andrea, Daniel sí dispone de herramientas lingüísticas para hacerse entender, son registros conocidos por la psicóloga, son lugares que puede seguir en el registro de esa entrevista. Daniel presenta una vida comprobable a los efectos de la acusación que se llevó a cabo contra sus padres. Pensar al otro en términos comunicacionales se vuelve posible y representarlo bajo los términos de la justicia y la lógica de la cámara gesell pareciera ser que también.

La edad y la experiencia narrativa de Daniel lo ubican en un lugar conocido para el narrar. A pesar de que la legislación argentina busca no revictimizar a las víctimas, Daniel y Mikaela son ejemplos de que la enunciación de la experiencia traumática ya había sido institucionalizada anteriormente.

\section{Mikaela}

Mikaela tiene 15 años al momento de la entrevista. Violentada por su padrastro durante años y a pedido del Departamento Judicial, la ONG interviene en el caso con una EP para ver en qué estado se encuentra la joven. Como mencionamos líneas arriba, el padrastro hasta el día de hoy tiene pedido de captura por el secuestro y desaparición de su hermana más chica.

No es lo mismo que el pedido de una EP lo realice un juez, que un ingreso particular a la ONG o por derivación de otra organización como la escuela. Ya hay un objetivo inicial de uso de la EP y una causa en marcha. La sicóloga sabe que esta EP fue solicitada porque había certezas de las violaciones y maltratos, entonces ya hace preguntas relevantes a la causa. La búsqueda de la profesional fue que la joven sea lo más clara y explícita posible a los fines de citarla en el documento. Como decíamos, las partes no suelen mirar las grabaciones en gesell y mientras más detallado sea el informe, más se beneficia la víctima: 
Mikaela -A lo primero me empezó a tocar y más después me violo...me hizo de todo.

Psicóloga -¿Qué significa que te violó?”

Mikaela -Él me puso su pene adentro de mi vagina y yo me puse a llorar y casi me desmayo y él se asustó y me empezó a tirar agua y justo llegó mi mamá.

El informe reza: "se le pide que cuente que fue lo que sucedió hasta que logró contárselo a su abuela. Responde: yo estaba cansada, fui a la casa de mi abuela y le conté todo y mi abuela le avisó a mi mamá y mi mamá se fue a la Comisaría de Mariano Acosta. Se le pregunta el nombre de la persona que la abusó, responde Mario G., era la pareja de mi mamá.”

Esto puede ser contado en la medida que la ONG lo permita, en las dosis y formas en que lo habilite. En los entrenamientos de las terapeutas son insistentes sobre el tipo de atención que deben recibir los niños y niñas cuando se encuentren en la cámara: no fueron pocas las oportunidades en que jóvenes calificaron a terapeutas anteriores como desinteresadas, que jugaban con el celular o simplemente cortaban la sesión antes de tiempo.

Mikaela llegó al consultorio con este prejuicio, el buen entrenamiento de la terapeuta ayudó a que pudiera contar aquello que aparentemente no podía contar.

Y aquí vamos a tensionar un poco más la cuerda. Si partimos de la pregunta ¿es posible contar el dolor?, vimos que es un sentimiento intransferible pero al final llegamos al dispositivo de cámara gesell que propicia y está pensado para contar el dolor... siempre y cuando sea bajo sus normas y formas, ritmos, dinámicas y lógicas. Un dolor que no se lo transfiere en sí, sino la experiencia que lo ha causado, esa experiencia es lo que debe ser codificada para demostrar un dolor causado tipificado en términos de delito. La tensión donde quiero pararme es la que menciona Arfuch (2013) en diálogo con lo que decimos "más que indagar sobre la memoria me interesaba lo inolvidadizo, según la feliz expresión de Nicole Loraux, aquellos activo y punzante, performativo, capaz de conformar y subvertir el relato, de aparecer sin ser llamado en una simple conversación, en una actualidad que convive con lo cotidiano aun sin emerger, sin mostrarse, 
formando parte de la historia común y de cada biografía" (p. 14). Pero, el repliegue de la narración y como consecuencia el repliegue de la experiencia que menciona Benjamin en El Narrador, tiene que ver con la falta de relato, esa pérdida de la experiencia que se comparte del boca en boca y todo este trabajo artesanal que implica el narrar obliga a preguntarnos por el vacío de lo que no puede ser dicho.

Pero aquí tenemos otra historia. Estos sentires o relatos breves sobre el abuso sexual -según las mismas terapeutas- "siempre está". Sin necesidad de hablar las psicólogas aseguran que "esa sensación" siempre está, como un relato no dicho ¿acaso es eso posible? ¿Qué pasaría si la experiencia del abuso sexual pasa a ser un nudo troncal en la configuración de esa identidad? Si en realidad lo que no puede ser contado, en realidad, es lo performativo capaz de conformar relato, de aparecer sin ser llamado, como diría Arfuch.

\section{Un Test para medir el dolor}

"Gráficos: Se infiere en los dibujos realizados por Mikaela sentimientos de inseguridad, culpa, sometimiento, agresión, vergüenza y angustia contenida hacia sí misma, esto producto de la utilización de la represión como mecanismo de defensa contra impulsos y afectos que se relacionan con el hecho traumático atravesado y experimentado por Mikaela. En su relato aparecen animales como símbolos fálicos, gran preocupación e inquietud sexual. (...) Se puede observar en el gráfico de Persona Bajo la Lluvia que Mikaela se encontró vivenciando una situación de mucha presión, agobiante y estresante sobre ella misma; se observa ansiedad y sentimientos de indefensión.” (EP de Mikaela, p.8)

En cuanto al test Persona bajo la lluvia, "la consigna es dibuje a una persona bajo la lluvia. Lo que se busca indagar con este gráfico es la forma en la que el sujeto se adapta a las presiones externas, con que defensas cuenta para defenderse de esa situación estresante" (Müller y López, 2011, p. 34). Si bien son muchos los indicadores para leer estos gráficos citamos algunos solo para dimensionar el proceso de lectura: 
- “Ausencia de cinturón: fallas en la represión secundaria.

- Trazo entrecortado y en ángulo: excesiva reacción emocional. Hiperemotividad. Agresividad.

- Sonrisa maníaca: negación.

- Lluvia torrencial: representa una situación de mucha presión, muy estresante, agobiada. Se homologa con la presencia de rayos y lluvia sectorizada" (ídem).

"Dibujo Libre: en esta técnica son encontrados indicadores a tener en cuenta. Ante todo Andrea grafica a su abuela paterna, a la edad de 10 años, proyectando en este personaje aspectos de su propia personalidad. Por un lado la presencia de nubes como indicador emocional, da cuenta de que la niña se siente amenazada por el mundo adulto, especialmente por los padres (Munsterberg Koppitz, 2010, p. 100). La ausencia de nariz se encuentra más relacionada con una actitud tímida y retraída, sin agresividad manifiesta. Cuando un niño omite la nariz, está denotando una sensación de inmovilidad, aplomo e indefensión. La presencia de elementos fálicos, que es característico de los gráficos realizados por niños que han sido víctima de abuso sexual, se encuentra aquí plasmado en un objeto que tiene la niña dibujada entre sus piernas, con aparentes "pelitos" que se forman por el roce del jean, según Andrea misma refiere" (EP de Andrea, pp. 12-13).

Luego de la entrevista el dibujo libre es la primera técnica que se suele utilizar por lo abierto de su consigna. "Los comentarios que suelen acompañar al dibujo nos sumarán más datos" (ídem, 27) dirán las autoras. Se trata de una técnica proyectiva en la que el niño exteriorizará lo que le está ocurriendo. La batería de testeos no se realiza en cualquier orden y generalmente utilizan más de tres en casa caso. Pero, ¿por qué la utilización de dibujos?

"El dibujo es una manera de imitar la realidad, los niños/as realizan, en un primer momento, movimientos sobre la hoja y otra superficie y van dejando una marca. [...] el dibujo se vincula con imágenes mentales, que son la interiorización de las imitaciones de la realidad, y se relacionan con el dibujo, que también es imitación, pero exteriorizada y plasmada a través de instrumentos distintos al propio niño/a (lápices, pinturas, etc.)." (Müller y López, 2011, pp. 15-16) 
Ambas autoras trabajan hace décadas en la temática de abuso y en la producción de material para su estudio, todo el material que trabajan en consultorio se vuelve insumo para la confección de materiales de estudio como este libro. Como dicen las mismas, dos acciones muy placenteras para los niños/as se fusionan en la EP para la entrevista: jugar y dibujar. Estas dos acciones aparentemente inocentes, dentro de la cámara adquieren otro sentido y lo que se deriven de ella (dibujos o comentarios del niño/a) será utilitario (o no) para la causa. Si lo pensamos no habría inconveniente aparente, pero ¿qué dificultades acarrea el uso de los materiales confeccionados dentro de la cámara gesell para la causa? Y antes que esto, ¿cómo se transforma un "simple" dibujo en una prueba irrefutable de la existencia de un abuso sexual o violación?

Los test gráficos que trabajan con dibujos son: Dibujo espontáneo, dibujo libre, test Casa-Árbol-Persona (HTP/ House / Tree / Person), test de la casa, test del árbol, técnica del árbol de fantasía, test figura humana, test persona bajo la lluvia, test dos personas, test de la familia. Todos estos son test con consignas para dibujar (dibujan lo que el nombre indica) y se tratan de técnicas proyectivas gráficas donde su principal objetivo es mostrar el inconsciente de ese niño/a a través de dibujos de objetos distintos de sí. No es casual que en los informes finales de las EP las sicólogas expliquen mediante sustento bibliográfico que significa cada test y que apareció efectivamente en cada dibujo. Siempre el lenguaje debe ser sencillo de leer y comprensible para otras disciplinas, no siempre va a estar la sicóloga ante el juez o fiscal para dar explicaciones y en caso de que la llamen será en calidad de testigo con previa orden del juez de levantar el secreto profesional.

Esa batería de testeos son los argumentos con los que cuenta la terapeuta para dar cuenta del abuso o, dicho mejor, debe dar cuenta de la psiquis de ese niño/a. No se intenta comprobar una violación sino el daño que produjo ciertos comportamientos con el niño/a que podría llegar a ser un abuso sexual o violación. Determinados elementos plasmados en esos gráficos, además de señalar que le pasa por dentro a ese niño/a o joven van a encauzar la hipótesis del abuso o violación. Como en el caso de Andrea, fue muy "explícito", según su propia terapeuta lo explica, la alusión a objetos fálicos que tiene que ver con el abuso de parte de sus padres. 
Ahora bien, ¿cómo debieran ser los gráficos para que sean considerados como prueba? Recordemos que la terapeuta tendrá que tener en cuenta la correlatividad entre los distintos test gráficos (son los indicadores presentes en los dibujos) más los indicadores físicos y psicológicos. "Esto significa que el dibujo de genitales, por ejemplo, aunque es un factor importante a tener en cuenta, no debiera ser tomado como un indicador por sí mismo de la existencia de un abuso" (Müller y López, 2011, p. 52), esto debe ser tomado en cuenta junto a otros síntomas como enfermedades venéreas, sangrados, desórdenes alimenticios, y conductuales, etc. Entre estos indicadores el relato del abuso es indiscutible.

Existen otros testeos que no tienen que ver con gráficos, sí con la relación entre palabras, el "Inventario de Frases Revisado" es una prueba que trabaja con palabras espontáneas de los niños/as recogidas en consultorio. Según las especialistas, el inventario permite "medir" el impacto del trauma (detectar qué áreas resultaron más afectadas), trastornos en el comportamiento o a problemas cognitivos / físicos / emocionales.

"Mikaela puede reconocer que tiene miedo a estar sola, no puede dormir sola desde el momento de su abuso pensando que en cualquier momento puede llegar el Sr. Mario porque sabe donde vive. Se ve claramente aquí que es consciente de sus afectos negativos (miedo, tristeza, angustia) que le provocan angustia, sentirse distinta a sus amigas y sentimientos de soledad. Reconoce tener pesadillas recurrentes y problemas para dormir." (Resultado del Test de Frases Revisado. EP de Mikaela, p. 8)

Leído así puede ser entendido y comprendido casi por cualquiera que se encuentre familiarizado con la temática, pero ¿dónde aparecen los criterios de rigurosidad científica/disciplinar? los mismos que le van a habilitar profesionalización en la defensa de sus técnicas de recolección de datos. En una de las reuniones que mantuvimos con el equipo de salud para discutir algunos casos, recuerdo haber preguntado a la directora (quien además de ser reconocida a nivel internacional por el trabajo que realiza es una defensora a capa y espada de los testeos hechos en clínica) si había posibilidades de acceder a un relato (prueba de delito) de incesto sin los testeos. 
En caso de que el niño o niña no hablase, pregunté. Su respuesta fue inmediata: imposible saber sin testeos.

Ya en esta instancia podemos empezar a vislumbrar el problema que supone el uso de testeos para el rastreo de la experiencia traumática, no su contenido o uso en sí, pero sí el problema de la credibilidad y veracidad disciplinar que le atribuyen en determinadas situaciones. El problema que se plantea en cada caso es por la legitimidad de la misma disciplina para determinar qué debe ser tomado en cuenta y qué no. Pensemos, ¿con cuántas codificaciones llega el relato de experiencia traumática a aquellas personas idóneas encargadas de hacer cumplir la ley? Fui testigo durante los años de trabajo de campo de como el poder judicial descartó una y otra vez las pruebas presentadas desde la defensa que vinieran de aportes de la sicología por ser "inconsistente". Por supuesto que no estamos aquí para juzgar el uso o no de ciertas técnicas de recolección de datos, cada disciplina carga con sus estigmas y conflictos, pero sí estamos en condiciones de preguntarnos por el problema de la legitimidad disciplinar en el estudio de experiencias traumáticas.

Si bien decimos que los testeos son herramientas que utiliza la sicología para recolectar datos, podemos pensar a todo el dispositivo de la cámara gesell como una gran herramienta para la recolección y, por qué no, medidor del daño. Hay allí una codificadora que a través de los supuestos de su disciplina pregunta, escucha y observa, a través de la lente de su disciplina traduce todo lo realizado dentro del dispositivo en un formato de Evaluación para ser entregado. Esa matriz de entrevista interrogativa no parece molestar a nadie, aun en el caso con niños y niñas pequeñas como Martina la presencia de la terapeuta es interrogativa, está cumpliendo el mismo rol de un fiscal con la variación de las formas, dinámicas y metodologías.

Como dijimos anteriormente, a pesar de que la EP se planteara como una instancia de intercambio entre terapeuta y niño/a o joven para habilitar espacios de conversación, siguen apareciendo e imperando los tiempos, dinámicas y tópicos de otros. Podríamos suponer que dentro de la cámara hablan de "cualquier cosa" hasta dar con "el relato", pero todo lo que se dice y produce dentro de la cámara es insumo sensible de ser utilizado para la causa. Esto último supone, entonces, que no se habla de cualquier cosa ni de cualquier modo, en casos de abuso sexual se busca desde el principio dar con los indicadores de abuso sexual (desde la sicología no problematizan el proceso de construcción del indicador de abuso sexual, más bien hablan de "detectar" 
como algo ya dado con anterioridad). Muchos de sus procedimientos y categorías remiten a la búsqueda de patologías en cuerpos biológicos aunque se trate de una disciplina que responda a las ciencias humanas. ¿Estamos ante un proceso de patologización del crimen? ¿Qué diferencia a un pedófilo/perverso de un criminal racional que viola a su hija? ¿Qué rol juega el diagnóstico en la comprensión de estos crímenes?

Como vimos, el encuadre disciplinar que realizan las terapeutas a los testeos no contribuye en gran medida para avanzar (satisfactoriamente) con la causa. Aún con los dibujos y testeos, aún con las EP los jueces siguen dictando la falta de pruebas:

¿Qué falla?: el abordaje y la construcción de esa veracidad. ¿Y si esa veracidad fuera construida en cooperación con otras disciplinas científicas? ¿Y si el abordaje de la EP fuera interdisciplinar? Porque la normativa ya dictó sus márgenes para la comprensión del delito pero algo está pasando que quedan restos, resabios sin enmarcar, sin contemplar. Pareciera que dentro de estas categorías la profundidad y enormidad del problema no caben. Estas marcas disciplinares no son suficientes, entonces ¿cómo puede contribuir la Comunicación social como disciplina científica a la reflexión y acceso a la Experiencia Traumática? ¿Qué contribuciones disciplinares podemos prestar para su resolución judicial en términos favorables a las víctimas? 


\section{Segunda Situación Comunicativa}

Algunas aclaraciones:

Este apartado se escribió con retazos del diario de campo, esto incluye las reflexiones, preguntas y silencios en los márgenes del cuaderno mediano de tapa dura. Como mencionamos en el Capítulo 1, nuestros primeros diálogos con referentes o facilitadores de las reuniones de adultos fue allá por junio del 2012, aún muy reciente la idea y las ganas, tuve que cruzarme en los mismos pasillos de la ONG con uno de sus ideólogos para empezar a pensar la comparación de dos escenarios comunicativos. Ya para el 2013 asistí esporádicamente a las reuniones y con más continuidad durante el año 2014. Desde el principio dejé en claro a los organizadores que no iba a registrar ni grabar lo que dentro de esas paredes sucediera (o en el balcón, ya que solíamos sentarnos afuera), desde el inicio no me pareció leal, ni "correcto" en términos de reserva de su intimidad registrar en copresencia nada. $\mathrm{Y}$ es que, insisto, presenciar o escuchar en copresencia, frente a frente, cuerpo a cuerpo un relato que tiene que ver con el abuso sexual es el acceso a la intimidad de esa persona, a su cuarto privado, a su cuerpo. Se está quitando las ropas y exponiendo lo que le hicieron, lo que vivió. Esto de poner el cuerpo y llorar con el otro, o reír o angustiarse nos remite a situaciones primeras de comunicación directa (fundantes de la comunicación) donde la oralidad era todo, donde los gestos, sonidos, entonaciones (la kinésica, la proxémica y la prosódica) lo eran todo. En tiempos donde aparenta que todo puede ser registrado en soportes digitales y sensibles de ser compartidos, donde todo debe ser recordado mediante distintos soportes memoriosos ${ }^{35}$, fue un desafío volver a la memoria de la investigadora para el registro de lo oral y la escritura (pos) de los diálogos. Tuvimos que aprender a sostener la mirada ante el dolor, comprender los llantos y aguantar los silencios. Porque es eso: el cuerpo aguanta cuando debe exponerse a tanta intimidad.

\footnotetext{
${ }^{35}$ Pensemos en la cantidad de fotografías que tomamos por día, cuantos audios de WhatsApp grabamos, todos los dispositivos que tenemos para registrar en las redes sociales ponen en tensión este "derecho al olvido" del que habla Theidon. En investigación a veces hasta entramos en esta lógica de querer registrarlo todo, los papeles se vuelven fundamentales, las entrevistas y sus desgrabaciones, la ansiedad de tener o llevarnos "algo" del otro/a, aunque esto no sea más que sus palabras, que en definitiva, es su mundo.
} 
Entonces, no es casual que los registros del Diario de Campo estén cruzados con notas referidas a mi estado anímico de ese día, a mis errores, a mi falta de ganas de asistir o lo contrario. Este diario de campo, lo hacía después de las reuniones y en la tranquilidad de mi hogar, tiene las características de alguien que piensa todo el camino de vuelta (caminando) lo que acabó de escuchar ese día. Y a veces no podía llegar a mi casa, las ansias de escribir y que no se escape nada me encontraban en un bar porteño por mitad de camino. Hay registros que perdí por mi propia incapacidad de escribir sus experiencias y dolores, se perdieron días de diario porque sabía que si algunos secretos no los escribía me iba a olvidar. Y era mejor.

De igual forma consideré que hay relatos que yo no tenía derecho a escuchar, derecho como ese acuerdo mutuo de pares con el que se rige un grupo de ayuda y dice que todos y todas vamos a compartir experiencias. No fueron pocas las veces en que consideré mezquina mi labor científica y simplemente no registré ni escribí sobre algunas personas que escuché relatar años de ansias de muerte. Si no las escribía era como resguardarlas. Y yo podría olvidar también.

Lo que haré a continuación será mechar pasajes de mi diario confeccionado a lo largo de los años de campo (y posterior a finalizar el campo) para trasladar al lector a la "cotidianidad" de mis reflexiones, si se quiere. Veremos -al finalizar- si esta metodología de trabajo aporta en alguna medida al estudio cara a cara de experiencia traumática sin necesidad de un registro en simultáneo. Vamos a problematizar la copresencia del investigador y las personas que intervienen en la investigación para fines investigativos. 


\section{La Experiencia}

¿Cómo apareció la cuestión de la experiencia en este grupo?

Al finalizar una de las reuniones allá por junio (2014) me hice una serie de preguntas sobre la experiencia ya que apareció con fuerza por aquellos tiempos. Por supuesto no como tópico y lo que eso implica, sino como respuesta a determinadas situaciones violentas (por fuera de sus abusos) que atravesaron algunos y algunas participantes. Ese día, hablamos sobre qué significa haber atravesado la experiencia del abuso entre otras situaciones de violencias, como esa "preparación" (como la llaman algunas participantes) de niñas juega como antesala y "las pone en bandeja", vulnerables, para futuras situaciones violentas con sus hijas y parejas.

Esta "preparación" tiene que ver con prepararlas de niñas para casarse, juntarse o enamorarse de un "psicópata”, "perverso", abusador. Las que atravesaron de pequeñas la experiencia del abuso sexual sostienen que es algo que tienen que trabajarlo, tener en su haber esos maltratos es leído casi como una condena, destino, de lo que serán (y fueron) sus vidas ahora de grandes. Esto no es casual, en este grupo todas las mujeres con hijos/as que asisten -en calidad de madre protectora porque sus hijos o hijas han sido abusadas/os- han sufrido abuso sexual y violencia de todo tipo en sus infancias. Es decir, si se acercaron al grupo para ayudar a sus hijos/as y asesorarse, terminan ellas utilizando el espacio para fines personales también. Por momentos y escuchando sus historias de vida, hasta podría trazar trayectorias de violencias de generación en generación, que no sería nada nuevo, pero asocia un "abuso no resuelto" de niños/as con su presente de figura protectora de sus hijos/as que están siendo abusados por sus parejas/padres.

Distinto pasó con algunos varones adultos, los que han atravesado la experiencia del abuso de niños perciben otra "funcionalidad" de esa experiencia, otra percepción de su experiencia traumática que tiene que ver con el "estar alertas" ante nuevas situaciones abusivas. La experiencia de niños resultó ser insumo para la alerta y el cuidado de adultos. "Con las antenas paradas" como dijeron en varios encuentros, los alertó para detectar a un "psicópata" o abusador y no volver a caer en su "trampa". He de mencionar que cuando se refieren a un/a "psicópata", "perverso/a" o abusador/a su concepción viene del campo de la psicología. Lo curioso de este grupo es que sus organizadores se instruyeron (y lo siguen haciendo) en la temática del abuso, vamos a 
ver como su "activismo político" -como ellos/as lo denominan- se cruza con actividades realizadas desde la Asociación de Psicólogos, carreras como psicología y trabajo social, en algunos miembros es muy evidente las huellas discursivas de otras disciplinas al hablar. Con cada presentación de sus historias de vida en público, su discurso es trabajado, pulido, con un encuadre teórico adecuado. No es un hijo de puta, es un perverso, dirán. Pero estas reflexiones vinieron mucho después, por ahora llamó mi atención como en esta reunión en particular aparecieron los usos de la experiencia del abuso sexual:

"En un momento la cuestión de la experiencia apareció. ¿Cómo aparece la prevención luego de pasar por una experiencia de abuso? En sintonía con esto y contradiciendo al mismo tiempo, sostenían que una persona que vivió en situaciones límites y de extrema vulnerabilidad o de violencia (los casos de Beatríz, Vanesa, Alfonso y Susana) están como "servidos en bandeja" para caer en manos de un sicópata. Omar contó el caso de cuando tenía 15 años y viajaba en colectivo con uno de sus amigos, estaba borracho y en la parte trasera del colectivo se les acerca un hombre adulto que los "engatusó", "seducción" es la palabra que utilizó, Omar contó que el quedó como atrapado entre lo que le decía este señor (les invitaba a tomar unos tragos a su casa) el amigo reacciona y casi se va a las trompadas. Omar sostiene que si no fuera por este amigo él no se salvaba, que estaba preparado para caer en las manos de cualquier sicópata. Esto es algo que aparece muy de seguido, el supuesto "entrenamiento" que reciben desde pequeños para soportar o elegir a un/a sicópata a su lado. En el caso de Susana y Vanesa, ellas estuvieron casadas con el violador (de sus hijas) ${ }^{36}$, ante la pregunta de cómo puede ser que se enamoraran de un abusador, Susana contesta que estaban preparadas desde pequeñas para eso, haber sufrido esas violencias las hace vulnerables a esas situaciones límites. Francisco dijo que luego de su experiencia él siempre estuvo muy atento, incluso hay una anécdota de él yendo a la escuela y un adulto diciéndole cosas como qué lindo muchachito e invitándole a entrar a la casa... Francisco dice que había algo ahí que no le cerraba, que le

\footnotetext{
${ }^{36}$ Ambas se enteran muchos años después de que sus hijas (ya adolescentes) estaban siendo violadas por sus padres.
} 
parecía que estaba mal... eso es porque pasaste por la experiencia, le contesta Rosana. Pero aún con la experiencia en su haber, todos los adultos más grandes del grupo, por lo menos habían vuelto a atravesar situaciones de abuso posterior a la primera vez (algunos con sus hijas).” (Diario de Campo del día 16/06/2014)

Sólo algunos paréntesis porque intervienen muchas personas: de Omar hemos hablado en el capítulo 1 de la tesis, Vanesa tiene tres hijas: dos con el abusador de sus hijas y una de él con otra mujer. Las tres desde pequeñas y durante 10 años fueron abusadas por el padre y por su abuelo paterno. Con varios abortos de por medio e intentos de suicidio por parte de la mayor de ellas, Vanesa tardó mucho tiempo en asociar los distintos desórdenes de sus hijas con las violaciones que estaban sufriendo por parte del abuelo y padre biológico de las chicas. Les dieron 8 años de cárcel de los cuales dos pasaron en la tranquilidad de su hogar por cuestiones médicas. El pedido de justicia y movilización hizo rever el pedido a cárcel común y hoy lo cumplen en Sierra Chica.

La hija de Susana tenía 14 años cuando pudo contarle a su madre lo que su padre le estuvo haciendo todos esos años, hace muchos años. Ni bien toma conocimiento de estos hechos y con la carga y dolor de sentir que durante todo ese tiempo fue bajo sus narices los abusos y no se die cuenta, inició un peregrinar por la justicia para encarcelar a su ex marido y progenitor de la joven. Generalmente este sentimiento de impotencia y bronca hacia sí mismas aparece en todos los relatos de madres protectoras de sus hijos/as abusados/as, discursivamente aparece este "me casé con un psicópata/violador" o "metí a mi casa a un violador". Toda la carga del cuidado del niño/a pasa por esa mujer como así los sentimientos de culpa, ya en el grupo la reflexión pasa por preguntarse, ¿y por qué no? si a mí me lo hicieron también. Casi como algo causal, casi como una correlación en la cadena de desgracias. Que las madres hayan atravesado por la misma experiencia remite a esta "preparación" de la que hablamos líneas arriba. En las únicas oportunidades que tomé contacto con varones adultos protectores de sus hijos fueron en casos de abusos y violaciones sufridos dentro de organizaciones como escuelas (religiosas). Conocido fue el caso del profesor de educación física acusado de abusar a niños y niñas de 3 a 4 años, sacarles fotos y grabarlos, los medios dijeron que fueron 4 denuncias penales, los padres que acudieron a las reuniones dicen que el número de niños y niñas abusadas ascienden a más de 100. 
Francisco es el miembro más viejo del grupo. 70 años al momento en que estos registros fueron escritos. Fue abusado por su profesor de educación física cuando tenía 11 años, en la escuela a la que asistía. ¿Lo llamativo? que en 70 años de vida decidió contar su experiencia con el abuso. La sensación de "liberación" lo ha dicho más de uno/a, es arrancarse el relato como sea, compartirlo y hacerlo menos doloroso. Francisco se entera del grupo a través de los medios de comunicación que durante algunos meses del 2014 le dedicaron mucha tinta y pantalla a la cuestión del incesto. Líneas abajo veremos la continuación de estos discursos y su transformación en discurso mediático.

En este momento del trabajo surgieron estas preguntas:

“¿Qué función cumple la experiencia en estos espacios?; en términos del investigador: ¿Hasta qué punto la no disociación (en términos terapéuticos) es utilitaria para la investigación?

¿Varía el uso del testimonio con el paso del tiempo?

¿Y la fascinación por la violencia? ¿Por qué la necesidad del detalle?

¿Es posible acceder a la experiencia del otro a través de la experiencia auditiva (escucha de testimonios)?" (Diario de Campo del mismo día)

Con respecto al contar la experiencia y su credibilidad, no aparece tan marcado este descreimiento hacia los adultos que están contando, más bien lo contrario. Cuando transformaron su experiencia en testimonio (de vida y como sobrevivientes) nadie los contradijo, ni refutó nunca. Con esta seguridad hablan en público y convierten el relato en experiencia épica, como quién ha podido (sobre)vivir lo suficiente para contarlo, de hecho el término "sobreviviente" que no es sólo de Argentina, sino que tiene sus orígenes en las primeras organizaciones de adultos que fueron víctimas de abusos por parte de curas católicos en EEUU en los 70. La mayoría eran niños y niñas que concurrían a misa o ayudaban al cura en sus tareas en la parroquia, el término remite a: "somos sobrevivientes a la pérdida de la fe, es todo lo que teníamos en ese momento y ellos lo destruyeron". El término es más preciso que el de "víctima", que si bien es un estado que reconocen y por momentos se ubican allí, el de sobrevivientes da cuenta del horror que vivieron durante años y hoy pueden contarlo desde la experiencia. 
Esta denominación se traslada no sólo a Argentina sino a otras partes del continente para nombrar a adultos y adultas que atravesaron la misma experiencia.

"Susana siempre recalca que el testimonio en primera persona tiene la ventaja de que nadie te lo puede refutar, a diferencia de las teorías científicas o debates legales, el testimonio personal tiene una fuerza particular."

Y sigue el diario de ese día:

"La experiencia apareció en esta reunión a través del alerta, cómo el haber atravesado por situaciones de violencia hace que las antenas estén más atentas. Rosana contó que siempre quiere poner en su lugar, decirle algo a cualquier abusador que se le presente (sea de cualquier tipo aclara). Susana dijo que la experiencia no es garantía de nada, muy por el contrario, entrena a cualquier mujer o varón para caer en manos de otro abusador.

Beatríz se volvió a quebrar. Mi padre que era un violento, que me gatillaba en la cabeza y yo no sabía cuando iba a salir la bala. Mi hermana que abusaba de mí, mi papá andaba en calzoncillos por toda la casa. Un combo perfecto para que enloquezca. Suele repetir que la gente piensa que está loca, que las amigas de su hermana piensan que está loca."

Acá aparecen dos maneras de ver o entender la experiencia del abuso sexual, por un lado como testimonio de vida y casi un "ejemplo" de cómo seguir adelante ante tremendas vejaciones, y por el otro como elementos que hacen a la subjetivación de esa persona. En el primer caso, podemos detectar algunos elementos que nos permiten ver la matriz testimonial de esta situación comunicativa, como decíamos, los lugares donde lo presentan son simposios sobre la temática del ASI, paneles junto a otros profesionales (psicólogos y terapeutas presentan su marco disciplinar para hablar sobre la problemática y los/as adultos/as sobrevivientes cuentan/exponen su historia de vida), para algún módulo de alguna que otra carrera y campañas afín. El testimonio se compone de elementos bien conocidos: un contexto en un mundo infantil, casa familiar, escuela o grupos de iglesia; un/a personaje confiable y seguro en un principio, que deviene en monstruo luego, que envuelve, cautiva, ataca y amenaza, la soledad, la angustia, la vergüenza y la certeza del descreimiento total por parte de toda la familia. Años de sortear distintos pozos: desórdenes alimenticios, intentos de suicidio, 
problemas para mantener relaciones amorosas-íntimas "saludables" que tiene que ver con desarrollar cierto estado de tranquilidad, la depresión... son historias que se repiten una y otra vez, círculos viciosos imposibles de cortar. Y llegó el día en que "despertaron", conocieron el grupo por distintos medios, se encontraron con iguales, pudieron contar, la liberación y la esperanza que la militancia social sabe inyectar. La Alegría del encuentro es algo siempre presente en los discurso de los organizadores, por supuesto que el momento del contar siempre lleno de dolor y angustia se presenta, pero el aporte y la esperanza de encarar la tarea como una tarea épica, de llevar esa esperanza a otros lugares tiene como corolario "somos los adultos que nos hubiera gustado encontrar en aquel momento".

Estos elementos de la situación testimonial de enunciación tiene coincidencias con los testimonios de sobrevivientes de los centros clandestinos y legales de la última dictadura cívica eclesiástica militar que azotó parte del continente. Más específicamente en Argentina, dónde la matriz testimonial con respecto a los y las sobrevivientes se reitera no sólo en los juicios, pedidos de justicia, actos en conmemoración como así en investigaciones científicas, comisiones de la verdad, ficción, relatos de vida.

"No es casual que antes de iniciar su juicio, Omar asistió a reuniones con la CODESEH (Comité para la Defensa de la Salud, la Ética y los Derechos Humanos), un grupo que trabaja con crímenes de lesa humanidad y prepara a las víctimas para soportar testimoniar durante los juicios (han trabajado con personas como Taiana cuando declaró por su secuestro en los 70). Una vez más, el paralelismo de estos crímenes aparece." (Diario de Campo del día 16/06/14) 
De la experiencia al discurso público: El Testimonio de Vida

"Mi objetivo es claro, evitar que esto vuelva a pasar" -Rosana. Diario de Campo del día 06/09/14-

“Llegué a esta organización porque me entero en algún momento del 2009 que el padre de mi hija -yo ya estaba separada hacía varios años- viene la hija mayor de él a contarme que había sido abusada por él cuando tenía la misma edad de mi hija. Ese día me cayeron 40 años de mi vida encima.” (Susana durante el panel "El abuso sexual a niños y niñas. Relatos de sobrevivientes, en primera persona y con su propia voz", durante unas Jornadas de Reflexión el 05/11/14)

Si en la primera situación comunicativa luchábamos contra el "desorden" del relato, en el discurso público encontraremos un orden cronológico, causal, personajes y hasta el raciocinio de lo que vivieron. Precisamente, en éstos espacios cabe la duda si resistirían a otra clase de discursos que no fueran así, la lógica con la que se plantean no habilita otros formatos. La panelista anterior -profesora de la UBA de la Cátedra de Derechos Humanos- decía “debemos politizar estos hechos. Éstos son hechos públicos, no privados", y en este "públicos" cabría ver cuánto resisten estas situaciones comunicativas (públicas) a lo amorfo del relato de una experiencia traumática contada por primera vez.

Existe un antes y un después cuando toman contacto con el grupo de pares, es un quiebre en sus biografías, esto de "encontrar" a los pares, la palabra como sanación y la esperanza del recuerdo tiene características (¿simbólicas?) comunes con movimientos cristianos que hacen hincapié en el "encuentro" con la palabra de Dios y su posterior sanación. Así, y en los testimonios hecho públicos, se pueden rastrear huellas o marcas similares a los testimonios que escuchamos en cultos con aquellos pastores carismáticos que invitan al escenario a personas del público que cuentan cómo eran sus vidas antes de encontrar "la palabra de Dios". 
"Alrededor de 30 y pico años después de mi abuso pude decir que aquello fue un abuso. Pude llorar. La palabra es sanadora, ponerle nombre a las cosas ayuda a que las cosas se encaucen." (Alfonso durante el panel "El abuso sexual a niños y niñas. Relatos de sobrevivientes, en primera persona y con su propia voz", durante unas Jornadas de Reflexión ${ }^{37}$ el 05/11/14)

El encuentro remite a un espacio de comunión, de intercambio de pares donde, como dijo Susana, "en el encuentro con el otro una se tranquiliza bastante". Tanto los testimonios en público como los relatos enunciados dentro del grupo ubican esta "llegada al grupo" como sanadora, de renovación de esperanzas y fuerzas. Sobre todo fuerzas para afrontar nuevos desafíos, desafíos que tienen que ver con causas abiertas, otros/as decididos a encarar a su abusador ahora que se sienten fuertes y acompañados. Son varias las situaciones en que utilizan, estos nuevos elementos que encontraron en el grupo de pares.

“Olviden las cosas de antaño;

ya no vivan en el pasado.

¡Voy a hacer algo nuevo!

Ya está sucediendo, ¿no se dan cuenta?

Estoy abriendo un camino en el desierto, y ríos en lugares desolados"

(Isaías, 43, pp. 18-19. Nuevo Testamento).

No es difícil rastrear esta matriz testimonial en la Argentina, si bien nombramos al culto carismático como una situación comunicativa en que se registra esta acción, existen otras situaciones que supieron marcar herida en estepaís:

"Nos reuníamos de forma aislada en distintos bares con otras madres que estaban atravesando por lo mismo, intercambiábamos información de los lugares a los que habíamos ido, con quién habíamos hablado, quién nos había ayudado, compartimos recursos (...)."

\footnotetext{
${ }^{37} 13^{\circ}$ Jornadas de Estudio y Reflexión: Las Múltiples formas de revictimización de niños y niñas víctimas de violencia de género, organizado por Shalom Bait el día 05 de noviembre del 2014. Buenos Aires.
} 
¿Suena conocido el relato? Hay muchos elementos discursivos que remiten a aquellos años oscuros de dictadura, y no son pocos los que dicen que sus crímenes tienen coincidencias: la tortura, el miedo permanente, las secuelas posteriores. Huellas de un relato épico pueden rastrearse, y es que no son víctimas sino militantes por los derechos de la infancia y es que en calidad de militantes testimonian. Sobre todo Omar, quien fuera el único en el grupo que tuvo éxito con su caso y pudo llevar a la cárcel a su abusador, tarea nada sencilla cuando el victimario es cura y profesor. El caso de Omar lo presentan casi como una cruzada épica de pedido de justicia. Este desplazamiento del relato del grupo de pares hacia el terreno de lo público sólo lo dan los organizadores de los encuentros, quienes han atravesado un período de duelo importante y pudieron transformar en testimonio aquella experiencia. $Y$ es que piensan al grupo de pares como espacio privado que en un principio (allá por el 2012) no lo tenían muy claro ni establecido, pero ya para el 2014 pudieron establecer reglas y pautas fijas de funcionamiento.

"(...) Con respecto a esto Omar intervino, por primera vez desde que tengo memoria en estos dos años, en referencia a las pautas de funcionamiento del grupo. Yanina, desde que se sentó, tomó notas de todo lo que se decía en la ronda de presentación y sobre las experiencias compartidas. Este es un grupo de pares, eso significa que esto es horizontal, anónimo y privado. Esto con respecto a las notas que te veo tomar, no podemos registrar nada de lo que escuchamos ni vemos acá, la intervención pública que puede llegar a hacer cada uno es a título personal pero más allá de eso no lo podemos hacer. Alfonso comentó algo más sobre esto, recalcando lo de los juicios de valor que pueden despertar. Yanina tuvo que dejar de tomar notas. Nunca más volvió." (Diario de Campo del día $4 / 10 / 14)^{38}$.

\footnotetext{
${ }^{38}$ Esto con respecto a nuevas integrantes que se habían sumado ese día al grupo. Luego de esta intervención Yanina no volvió más al grupo.
} 
Ya para esta época el grupo contaba con talleres de formación política (según sus propios términos) donde el objetivo era presenciar y debatir paneles con distintas especialistas sobre la problemática. La palabra empoderar apareció mucho por aquellos meses y fue allí donde pudieron determinar qué significaba el anonimato y la privacidad para ellos/as: hasta ese momento no hubo problemas en registrar nada. De hecho cuando inicio mis actividades de campo con este grupo una de sus organizadoras me ofrece grabar las reuniones para lograr mayor precisión en el relato. Por supuesto que me negué, entendía que por cuestiones éticas no podía hacerlo.

Todo el tiempo aparece esta tensión entre lo que hay que contar y lo que hay que mantener en secreto, lo privado y lo público. Y es que los/as que hablan son los más "viejos" en permanencia en el grupo y los organizadores las caras visibles de la organización. El secreto dentro de esta lógica adquiere otras características, ya no para resguardar al abusador sino para resguardar a la víctima.

Esta interpelación constante por el hablar, contar, sacar de la arena de lo privado a lo público, visibilizar estos crímenes tiene resonancia en varios discursos sociales. Por supuesto que las fronteras nunca son claras y allí donde se visibiliza se expone, y donde se expone se corren riesgos. Los medios de comunicación son un ejemplo de este movimiento, en su afán por volver todo un gran espectáculo, un show del dolor exponen hasta el límite a las víctimas. El hacer público estos crímenes no tiene que ver con esto último sino con creerle a las víctimas en principio, "(...) la responsabilidad que tomamos como adultos es tratar de que con nuestro testimonio no les pase lo mismo a otros niños" (Susana). Este desplazamiento de lo íntimo a lo público es lo que pretenden con denunciar y contar lo que les hicieron, ¿recuerdan el cuento de la terapeuta a Martina? Es casi la misma lógica... contar pero ya no en un consultorio, sino en las familias, en los grupos, es el alerta constante. 


\section{¿La producción de un mensaje salvador-espectacular? El pasaje de forma a bienes simbólicos "transmisible"}

RM -Ayudar. Ayudar es una palabra tan amplia que ni siquiera yo sé desde que lugar puedo hacerlo. Sé que nadie más que yo y mi mamá pueden saber el dolor que se siente. Mi mamá desde el lugar de madre y decirme: me enamoré de un tipo que acarició mi panza, que... no sé, la vio nacer e hizo esto. Como darte cuenta, hay mujeres que no se dan cuenta nunca, mi mamá tardó pero se dio cuenta. Y yo desde mi lugar desde lo que yo viví digo denunciá, te pasó, denunciá. Hablá, digo, también las cosas se cambian desde adentro porque cuando me pongo a pensar hay chicas que van y denuncian pero tienen al padre, al tío, al padrastro viviendo adentro de la casa y hasta que no es culpable sigue adentro de la casa. ¿Y qué son? ¿Tres años más de calvario? Tres años más de infierno. (RM en entrevista con Fantino. Canal América).

Antes que la cuestión mediática, la pregunta que sobrevuela este apartado es, ¿cómo transforman un relato amorfo en bienes simbólicos transmisibles? En términos de Hall (1980) y Thompson (1997). ¿Qué sucede con el relato cuando es convertido en testimonio y este es compartido como un bien simbólico? Cuando ese mismo relato es transformado para ser dicho en público y en los medios, ¿cuánto permite el medio moldear la experiencia?

"Al producir formas simbólicas y transmitirlas a los otros, los individuos generalmente emplean un technical medium. Los medios técnicos son el sustrato material de las formas simbólicas, esto es, los elementos materiales con los que, y a través de los cuales, la información o el contenido simbólico se fija y transmite de un emisor a un receptor." (Thompson, 1997, p.36)

En este afán de "concientizar" sobre la problemática, el grupo no tardó mucho tiempo en percatarse de la importancia de los medios masivos (industriales) de comunicación, de hecho fueron un gran aliado para presionar y marcar presencia frente a algunos dictámenes en tribunales. ¿Permite el medio narrar la experiencia traumática? 
¿Le interesa a los números del rating? ¿Qué más debiera aparecer para que sea considerada transmisible el relato del abuso en los medios?

"Estas prácticas tienen por “objeto" el significado y los mensajes, bajo la forma de signos-vehículos organizados de un modo específico, como cualquier forma de comunicación o lenguaje, a través de la puesta en funcionamiento de códigos dentro de la cadena sintagmática de un discurso. Los aparatos, relaciones y prácticas de producción así concebidas, emergen en un momento dado (el momento de producción/circulación) bajo la forma de vehículos simbólicos constituidos dentro de las reglas del lenguaje." (Hall, 1980, p.129)

¿Cómo es esta producción discursiva desde el grupo pensada (y hecha) para ser compartida? El testimonio que dan está pensado y preparado para un público adulto, familiarizado con la temática; recuerdo cuando fueron invitados a "dar su testimonio" en una escuela de la provincia de Buenos Aires, llegaron por supuesto con el mismo discurso que utilizan en ocasiones como éstas. Cuál fue su sorpresa al encontrarse con una audiencia joven, del secundario y no docentes y padres como habían pensado. Rápidamente la estrategia discursiva cambió. Y el mensaje también.

Pero en este pasaje de formas para los medios, en principio, llamó la atención por todas las similitudes con el relato enunciado dentro del grupo de pares. Es como si no hubiera diferencias. Pero, revisando y cruzando, el medio ofrecía otras formas del contar: 
Periodista -¿Cómo nace el Grupo (...)?

Susana -Como la confluencia y síntesis de dos experiencias individuales de lucha, y de permanente búsqueda y anhelo de poder dar con una salida colectiva a esta tremenda injusticia del abuso sexual infantil. En el 2012 y a partir de la visibilización pública de la lucha de Omar, numerosas víctimas adultas comenzaron a acercarse, entusiasmadas ante el hecho de que alguien se animaba a hacer visible lo que ellas venían silenciando desde varios años. En un primer momento, la identidad del grupo se conformaba alrededor de la experiencia traumática de abuso sexual infantil, pero a medida que pasaba el tiempo y a través de las múltiples actividades de visibilización en la que participábamos dando nuestro testimonio, y conocíamos más personas sensibilizadas con el tema, nos dimos cuenta que si a la experiencia de haber sido víctima de abuso sexual infantil no le damos perspectiva de acción en el presente, se queda en lo que para nosotros es una retórica vacía. Como dicen los grupos de familiares de alcohólicos: nuestros vínculos no tienen que tener un desastre en común, sino tener una solución en común. Por eso, en esta etapa adoptamos el nombre (...), como colectivo de adultos que se han decidido a cuidar, proteger y hacer valer los derechos de la infancia, teniendo en cuenta que somos los adultos los que causamos esta tremenda injusticia en los niños, niñas y adolescentes.

(Diario Página 12. Nota de Mariana Carbajal ${ }^{39}$ a los organizadores del grupo Susana y Omar. Recuperado el día 23/03/15)

Como mencionamos, este grupo fue convocado en muchas ocasiones por distintos medios (radiales, gráficos y televisivos) para dar su testimonio, solicitados como la voz legitimada, este grupo siempre focalizó en su actividad militante y de ayuda de pares, actividad que no dan mucha más precisión. Omar, incluso, fue entrevistado y se ha realizado un documental entero con su caso, y es que los abusos dentro de la iglesia católica no fueron pocos y el ex cura y profesor del colegio religioso recibió muchas denuncias penales y civiles en su contra por el delito de abuso sexual a

\footnotetext{
${ }^{39}$ Mariana Carbajal estuvo muy comprometida con la temática por aquellos años, ha hecho varias entrevistas a Omar y Susana y a seguido en tv y gráfica varios casos de abusos sexuales. Es parte de la red PAR (Periodistas de Argentina en Red por una comunicación no sexista).
} 
estudiantes. Otro punto en la agenda mediática fueron los cientos de abusos cometidos durante años en el jardín maternal de otro colegio católico de un barrio porteño a niños y niñas de 3 a 5 años, el recorrido por distintos medios que realizaron los padres reflotó casos como los de Omar, considerado exitoso en el ambiente por lograr encarcelar a su abusador.

"Es bajo esta forma discursiva que se efectúa la circulación del "producto". Este proceso requiere, entonces, a la vez, del lado de la producción, sus instrumentos materiales -sus "medios" -y sus propios conjuntos de relaciones sociales (de producción): la organización y combinación de prácticas dentro de los aparatos de los medios de comunicación. Pero, es bajo una forma discursiva que la circulación del producto tiene lugar, así como su distribución a las distintas audiencias. Una vez completado, el discurso debe entonces ser traducido transformado, nuevamente- en prácticas sociales, si se desea que el circuito sea completo y eficaz." (Ídem, Hall)

En este pasaje de formas vemos la percepción de lo personal, íntimo, doloroso como insumo sensible de ser utilizado a los fines productivos. Productivos no con una lógica mercantilista pero sí en términos de provocar una acción. La transformación en práctica social, dirá Hall. Y es que esta "retórica vacía" que menciona Susana es la interpelación directa a la acción, el grupo buscó movilizarse más allá de la ayuda de pares y en esta movida de "visibilización" entran las mediaciones tecnológicas mediáticas y directa- copresencia. El formato les permite moverse dentro de estos límites a raíz del motor de la experiencia, pero esa experiencia debe atravesar muchas otras transformaciones para llegar a este compartir de bienes simbólicos: la esperanza, la acción, la superación del trauma.

"Yo había sido abusada en la infancia y yo había apostado a lo que esta sociedad dice: olvidá, seguí adelante, que te olvides, que sigas adelante, que pongas energías en cosas nuevas... y yo lo hice bastante bien durante muchos años. Hasta ese momento yo había sentido que mi infancia quedó atrás. Ese día me encontré con que no había quedado nada atrás y que tenía que obligadamente rescatar a esa niña que había sido." (Susana. Foro ${ }^{40}$ : La Palabra de los niños. 03/09/14)

\footnotetext{
${ }^{40}$ Foro organizado por APBA (Asociación Psicoanalítica de Buenos Aires) en la Biblioteca Nacional el día miércoles 3 de septiembre del 2014. Ciudad de Buenos Aires.
} 
Y sobre esto:

"Si bien una de las premisas máximas del grupo es no opinar sobre el accionar de los compañeros/as es inevitable con estas sensaciones tan viscerales. Sobre todo los/as que han aparecido en los medios: el dolor del duelo fue abruptamente interrumpido por la velocidad del medio que no hace otra cosa que confundir la racionalidad de la víctima. Esto es: van a decir cualquier cosa en un momento donde nadie podría ser coherente y racional.

¿Cómo hacer del dolor una bandera y estilo de vida? Es como recordártelo cada día de tu existencia el daño que te hicieron. Es muy difícil no meter una opinión normativa con respecto a lo que escuchamos allí dentro. La herida está en carne viva aún y desde allí perciben el mundo.

Todo el ambiente es dolor. Es como que si el dolor fuera, definitivamente, transferible." (Diario de Campo del día 01/11/14)

Como ya se pueden notar los cruces, estos mismos adultos que se reunían a compartir sus relatos en el grupo de pares, testimoniaron frente a audiencias interesadas en la problemática y para distintos medios. Aparentemente el discurso fue el mismo pero las concesiones, objetivos y modalidades variaron. La experiencia traumática atravesó varias codificaciones más y se nutrió de otras para circular en estos otros espacios. Sobre esto, muchos/as de los adultos/as con los que trabajamos en el grupo de pares "pegaron" el salto mediático y de pronto fueron invitados/as a varios programas de la tv abierta (aquí en Misiones se emiten por cable), de pronto pude escucharlos/as y verlos/as al interior de un programa de televisión o radio y dos días después en el grupo de pares. Ya no eran los organizadores quienes hablaban, siempre preparados para la exposición mediática, sino miembros que empezaron a asistir a las reuniones en el mismo periodo en que realicé el trabajo de campo. Durante tres años he visto personas ir y volver, he podido hacer el seguimiento de un mismo caso a través de los medios de comunicación y al mismo tiempo dentro del grupo, he podido presenciar los grandes cambios que sufre el relato cuando llega al grupo y lo cuenta por primera vez y luego sobre un escenario presentando su historia de vida en un panel junto a profesionales de la problemática. 
Todo esto sucedió durante el segundo semestre del 2014, los medios de comunicación pusieron en agenda al abuso sexual infantil y de pronto Omar, Susana, Alfredo, Rosana y Vanesa estaban sentados en distintos canales de tv y radios contando su experiencia. Escuchar y ver estas continuidades de los relatos que se emitieron (y escuché) del grupo de pares, al estudio de tv y radio es fascinante, otra situación comunicativa creada para contar. Y es que dar una entrevista siempre fue consensuado al interior del grupo, salvo que sean los organizadores, ellos no necesitaban consensuar, simplemente iban. Si bien recalcaban que cada uno habla a título personal, Omar y Susana lo hacían bajo el nombre del grupo de pares. Esta transformación del testimonio en narrativa mediática tuvo sus continuidades, sus quiebres y transformaciones.

La transformación de la experiencia en narrativas mediáticas son entendidas aquí como "un acto socialmente simbólico en un doble aspecto: a) adquiere sentido solo en un contexto social, y b) desempeña un papel en la construcción de ese contexto social como espacio de significación en el que están involucrados los actores sociales" (Rincón, 2006, p. 16). Es en la arena de la cultura que se van a disputar los sentidos, la comunicación y su soporte en forma de narrativas será el terreno privilegiado para ver las luchas y las disputas por el sentido mismo de la vida. Es dentro de estas estructuras de sentido que trascienden lo mediático que estas narrativas cobran sentido y producen efectos reales en sintonía, reforzando o contradiciendo el orden impuesto, siempre en respuesta de un gran diálogo.

Del grupo de pares y previamente consensuado no han salido personas que no estuvieran preparadas para hablar, siempre fueron los organizadores o miembros más antiguos, pero ¿qué sucede con todos aquellos relatos que son emitidos por primera vez en la arena de lo público a través de un medio de comunicación?

"La narración es una forma para convertirnos a nosotros y a los otros en historias que nos devuelven en forma de experiencia a la vida cotidiana. (...) comprendemos los textos de las culturas y los mundos de la vida desde los modos narrativos mediáticos que habitamos. (...) la comunicabilidad de los medios está mucho más en los modos de narrar que en los contenidos propiamente dichos (...) deben ser comprendidos más desde la narración que desde los argumentos, más desde el estilo y las estéticas que desde las razones y las ideologías." (Rincón, 2006, pp. 14-15) 
Hemos visto como periodistas han metido micrófonos en la boca sin consentimiento de las víctimas, como han expuesto el rostro de esa joven que acababa de salir de Tribunales, hemos escuchado como han preguntado barbaridades sin respetar el dolor de esa persona. ¿Qué sucede cuando el duelo de esa víctima es interrumpido abruptamente por un micrófono?

"Cuando la criminología mediática instala una víctima-héroe, explota algunas características particulares de ésta, como el histrionismo y quizás rasgos histéricos, las refuerza brindándole un escenario gigantesco para su desarrollo, pero, por sobre todo, la fija en el momento de extroversión de la culpa, la refuerza al máximo esa etapa, inmoviliza a la persona en ese momento e interrumpe brutalmente el camino de elaboración del duelo, o sea, de restablecimiento de su equilibrio emocional. La persona redefine su autopercepción como víctima y queda fijada en ese rol." (Zaffaroni, 2012, p.233)

Los medios no pudieron (¿o no quisieron?) contar de otra manera estas historias que no fuera a través del entretenimiento. Pero esta reflexión es como un espejo que nos devuelve cierta imagen distorsionada de la labor científica, ¿qué sucede cuando la matriz de la espectacularización devora todo? ¿Cómo investigamos sin caer en estas lógicas productivas?

"[...] los medios de comunicación de masas, para ganar comunicabilidad e intervención social, deben contar de nuevo la vida desde lo emocional; fabular desde el entretenimiento. Para eso narramos. Por eso, nuestra sociedad habita la estetización y la narrativización de la experiencia desde y en los universos frágiles de los medios de comunicación." (Rincón, 2006, p. 13)

Visto y considerando a partir de Rincón, la migración de estas formas del narrar por fuera de los medios por menos debe ser un alerta para aquellos investigadores que indagamos en estas aguas. ¿Cómo investigar sin convertir en un fetiche el problema de la representación del otro a partir de la narración de la experiencia traumática? Sin caer es ciertas fascinaciones que suele acarrear el problema de la violencia y opaca las reflexiones. El alerta en estos pasajes de formas sin dudas, debiera ser una fiel servidora. Pero continuemos con los medios: 
Periodista - ¿y tu mamá no se daba cuenta?

RM -Somos todas víctimas de una misma persona. Adentro de tu casa como me manipuló a mi diciéndome que esto era normal, pasa en todas las casas, estoy enamorado de vos, en vos veo a tu mamá cuando era joven.

Hija de Vanesa -Cuando nosotras salimos del programa de ayer muchísima gente nos llamó, nos escribió tanto apoyando nuestras historias y contándonos las de ella. Todas luchamos por dejar a las personas que hacen daño en la cárcel y nadie responde.

(Dos víctimas de abuso sexual ${ }^{41}$ en diálogo con Leo Montero y Verónica Lozano en AM, TELEFE).

Ya con el tiempo aparecieron otros grupos de ayuda en distintos lugares del país. Por esos vericuetos mediáticos dimos con una víctima de abuso sexual por parte de su progenitor, quién era parte de las Fuerzas Armadas por aquel entonces. La solía violar de niña en la base naval. Casi tres años después de estos abusos decide denunciarlo, debido/a pesar/y gracias a la agenda mediática los medios de comunicación se ocuparon bastante de este tema y por supuesto que utilizaron la causa a conveniencia política. Nadie la había preparado para hablar en los medios sobre su experiencia. Si hacemos un seguimiento durante varios meses en los que pudo transitar por distintos medios nacionales podemos notar como ese relato fue pulido y articulado. En uno de esos pasillos televisivos y gracias a la agenda mediática se conocen con la hija de una de las mujeres que asistían al grupo (Vanesa) y deciden moverse juntas en cuanto programa las inviten. Así tuvimos contacto más cercano con la joven y sus vericuetos judiciales. Por supuesto que tuvieron participación en el Encuentro Nacional de Mujeres que se realizó en Mar del Plata ese año, pero ya se notaba más cuerpo en ese relato, al igual que los que han atravesado por el "entrenamiento" de dar testimonio en varias situaciones comunicativas, ha podido borrar todo aquello que lo hacía ir por fuera de los

\footnotetext{
${ }^{41}$ Una de ellas es la hija de Vanesa, quien al igual que la otra joven habían conseguido presencia en varios medios para contar su historia. Cuesta imaginar que el impulso de las hijas de Vanesa hubiera sido posible sin "la inspiración" del grupo de pares y militancia en la que participó Vanesa activamente. Son historias cruzadas en varios puntos y todas las expuestas en este apartado tienen que ver con el grupo de pares.
} 
estándares del contar para un medio. ¿A qué llamamos ir por fuera de los estándares para el contar en un medio? mediante llanto, a los gritos, con cualquier manifestación que no vaya por el discurso articulado y medido. Este tipo de discurso prosperó y circuló.

Mirtha Legrand -Si yo te pregunto algo que no te gusta decime no Mirtha, la pasamos... no quiero molestarte. ¿Cómo empieza esta terrible historia?

RM -(...) estaría bueno que no te pongan el cartel de chica abusada y que se tome como valentía... para que otras chicas también se animen a denunciar.

Catherine Fulop -Eres un ejemplo para que otras chicas cuenten (...).

ML -¿Por qué no lo denunciaste de entrada?, ¿qué te decía él?

RM -Y porque es re difícil, yo nací con esa persona al lado.

ML: Vos decías que le recordabas a tu mamá...he leído. Todo lo que yo sé es de lo que he leído.

RM -Si, es súper perverso, encima vos nos ves a mi mamá y a mí y somos idénticas.

Niña Loly -¿Qué te decía para mantenerte en silencio? (preguntó incrédula)

RM -Nadie te va a creer me decía.

ML -¿Dónde era eso? (insiste Mirtha Legrand)

RM -(...) en la base naval. A mí me contratan como personal de limpieza a los 16 años porque yo me quería comprar una cámara para viajar a Bariloche.

Niña Loly -¿Pero por qué buscaste trabajar con él? (insiste nuevamente). 
RM -Porque yo cuando era chica solía ir a su trabajo porque me quedaba cerca de la escuela y él me llevaba ahí. Empecé a conocer a todos sus amigos de trabajo y comenté que quería comprarme una cámara para ir a Bariloche, entonces me dijeron podés empezar a hacer algunas tareas de limpieza acá y así vas juntando la plata.

ML: ¿Y él tenía relaciones con vos dentro de la base?

RM -Violaciones (aclara) Mirtha. En la base naval y muchas transcurrían desde las 12 de la noche hasta las 3 de la mañana.

ML: Yo quiero aclarar algo, para mí como conductora me es muy difícil ¿sabes? En un almuerzo donde estamos todos entre amigos y gente querida. Pero pienso que podés ayudar a tantas chicas que nos están viendo...

(Mesa de Mirtha Legrand por Canal 13 junto a Catherine Fulop, Mariana Antoniale o Niña Loly, un periodista de TN y Paz Martinez)

No fue el único relato que se fue puliendo y modificando con cada aparición. No hay nada nuevo en decir que los medios convierten todo en un show y la espectacularización del dolor es una constante, los medios como narradores del mundo dirá Rincón (2006), el punto aquí está en notar qué características tiene ese relato de experiencia traumática que atravesó varias instancias y varios pasajes para volverse un bien transmisible. La autorrefencialidad de la televisión es muy evidente, así Legrand trajo a la mesa la entrevista que esta joven había dado con Fantino, en AM hicieron referencia a una nota con $\mathrm{C} 5 \mathrm{~N}$ y así. Ya a esta altura, no puedo dejar de recordar los inicios de esta tesis: "lo más intransferible es el dolor". Pero, hasta este momento, pareciera que se lo transfiere y transmite todo el tiempo, bajo distintas formas y modalidades pero pudieron volver(lo) transferible a la experiencia traumática devenida en testimonio. 
RM -Subían la música. Entonces son cómplices. Ellos ayudaron a que yo fuera violada ahí dentro. Porque violada iba a ser violada, pero por ahí si ellos hubiesen parado esa situación no hubiera sido violada también ahí dentro. (Silencio) Porque no es fácil enfrentarse a una fuerza te da terror...De ahora inmediato no imagino los próximos años, a lo inmediato lo que quiero es ayudar, ver la manera...que las cosas tienen que cambiar que una chica no puede denunciar y seguir viviendo en la misma casa, es eso, es el dolor ese. Y no sé cómo...ese es el tema, no sé cómo hacerlo." (En referencia al personal de la Base)

Fantino -Vas a ayudar... mirá, yo entrevisté a muchísima gente y la capacidad de comunicarse se tiene o no se tiene, y vos tenés capacidad, tenés una luz muy especial que vos... esto pasó, fue horrendo, horrible pero vas a seguir ayudando, yo te aseguro que este es el momento que uno mira a la cámara y dice vamos muchachos ustedes que están en política, que trabajan en política es un momento para aparecer no como un oportunismo de aparecer por cuatro votos más con... sino que... o algún tipo que esté del otro lado y que en un momento diga me sobran 20 millones de pesos, tengo 500 palos, facturo, tengo campos acá, constructora acá, voy a juntarme con..., vamos a hacer, vamos a poner una sede y vamos a destinar tanta plata para que desde este lugar se ayude. Porque vos podés ayudar, sos pendeja, sos creíble, tenés una forma de comunicar lo que te pasa, ojalá que puedas seguir ayudando... ojalá. Además tenés ganas de ayudar, no es fácil canalizar todo esto en ayuda ¿eh? No se sí te habrás encontrado otras víctimas de estos infiernos hacia donde van y cómo terminan, tal vez no tienen ganas de ayudar, tal vez tienen ganas de cerrar esto, bajar la persiana...

$\mathbf{R M}$-Es la mayoría de la gente lo que quiere hacer, listo ya pasó y ya está...Me voy a vivir a (...) y me voy a vivir una vida nueva...pero yo no...

Fantino: -Vos no, vos querés ayudar.

(Misma joven de la mesa de Mirtha Legrand con Fantino).

¿Qué elementos habilita cada situación comunicativa para el contar? ¿Qué recursos utilizan en cada situación comunicativa para vivir la experiencia narrativa? 
Uno de los quiebres por el que atraviesan los relatos para volverse testimonios (en este pasaje del grupo de pares a los medios o a situaciones de exposición cara a cara con un público) tiene que ver con la categoría de "utilidad" del relato. El relato de la experiencia traumática que pudo ser enunciada dentro del grupo de pares debe volverse útil para convertirse en testimonio y ese testimonio debe ser capaz de transformar en alguna medida, o interpelar a la acción personal o grupal. “¿Es preferible una lectura inocente pero solidaria del testimonio a una deconstrucción de su metafísica de presencia, vista como cómplice con mecanismos neocoloniales de representación y/o con la ingenuidad interesada del intelectual del Primer Mundo?", se pregunta Beverley. "La respuesta en ambos casos debe ser que depende de las circunstancias. No es el tipo de lectura en sí del testimonio lo que es válido, sino la manera en que ésta se ajusta a las necesidades de la lucha (de liberación o simplemente de sobrevivencia) que están involucradas en la situación de enunciación del testimonio.” (Beverley, 1992, p.18)

Aquí, en estos testimonios la tensión está presente entre un testimonio víctimocéntrico (¿acaso existen por fuera?) y un testimonio (de vida) salvador que interpela. Frente a esa retórica vacía -como lo denuncia Susana- de solo testimoniar lo que vivieron, a una acción concreta con características políticas y a utilizar la palabra interpelando a la acción. Acción sin importar cuál fuera ya que al momento de presentar su propia propuesta de acción tampoco lo tenían muy resuelto, lo más fuerte que poseen y con objetivos claros como grupo es la ayuda de pares, en cuanto a la militancia lo ven más bien como una forma de "concientizar", con todas las contradicciones que esta palabra supone.

Y por último, si me permiten mencionar un pequeño gran triunfo del sistema capitalista, esta joven hoy por hoy es una de las caras de la marca de ropa y accesorios ONA SAEZ. Conocida a raíz de su transitar por los medios masivos de comunicación narrando su historia, la marca la contrata como modelo de su última colección otoñoinvierno (2015). Con un desfile realizado en Mar del Plata junto a modelos como Ingrid Grudke, Zaira Nara, Jessica Cirio, Sofía Zámolo, esta joven inauguró su paso por el modelaje de la mano de la marca internacional a partir de su exposición mediática a raíz de las violaciones de su padre. Con remeras con leyendas como "Violence is Never in Style" y "Free Woman" la marca saca su nueva línea de ropa con el objetivo de "ayudar a que las adolescentes y las mujeres en general salgan del miedo y se animen a denunciar" (sitio oficial). Una vez más, el capitalismo todo lo puede absorber y 
reinterpretar bajo sus propios códigos y consignas. Si nos quedaban dudas de la capacidad de volver mercancía lo simbólico que devino del dolor, aquí ONA SAEZ nos responde con brutal crudeza: todo lo puedo volver una marca (y muy cara por cierto). E1 dolor del incesto devenido en mercancía. Un pasaje de formas más dentro de nuestra cadena de transformaciones. 
VII. De la institucionalización de la figura del monstruo: El Perverso

¿Cómo se construye la criminalidad del perverso? ¿Quiénes y cómo "territorializan el miedo difuso"? se pregunta Tonkonoff (2007). Para empezar a desmenuzar esta figura es necesario localizar el debate que sobrevuela el análisis de la construcción del perverso: la violencia.

No existe sociedad sin violencia, los procesos de construcción de la alteridad radical siempre están presentes y los castigos de una sociedad como afirmación de un "nosotros" y un "ellos” también, pero ¿Qué rol cumplen, específicamente, estas dos instituciones en la construcción de estas alteridades radicalmente otras? ¿Qué elementos configuran la figura del perverso en ambas situaciones comunicativas? ¿Quién es el malo del relato y cómo lo instalan?

Pensar a la violencia a partir de la constitución misma de la sociedad significa romper epistemológicamente con varios supuestos. La violencia pasa a convertirse en un problema de constitución de las sociedades, un núcleo con fronteras difusas que hay que determinar. Es paradójica, no se la puede definir positivamente y es una transgresión de los principios fundamentales primarios: para que haya una transgresión primero tuvo que haber sido definida como tal. La pregunta que se hace Tarde, “¿qué es el crimen?", es pertinente hacerla aquí para empezar a pensar estos dispositivos/instituciones de codificación (simultáneamente se codifica y se delimita) de estas fronteras difusas. Siguiendo en esta línea de análisis, un crimen "es un acto sentido por el grupo social ambiente como un ataque y un problema" (Tarde, 2011, pág. 9), pero este termómetro de lo tolerante/intolerante varía con el tiempo y se sujeta a valores muy situados de ciertos períodos. Es así que, investigaciones como éstas, merecen ser bien situadas, ancladas en el período establecido para pensarlas, una vez que la clasificación y jerarquización de las violencias son situadas operan: ¿qué es lo más inconcebible en estas "tramas delictivas"?, nos preguntamos mientras recorremos los pasillos de la ONG. ¿Cómo preguntarnos por lo más impensado en materia de delitos dejando fuera la mirada sancionadora y moral? 
Y si la violencia es creada, delimitada, denominada, la misma es una creencia, un mito: el mito de la violencia. ¿El uso instrumental del mito de la violencia?

En(tre) estas codificaciones y pasajes de formas, la figura que pasó casi ileso a las transformaciones del relato es la figura del perverso. "Lo perverso" (llámese la perversa o el perverso de acuerdo al caso) es una figura que sorteó exitosamente los pasajes de formas y se cristalizó finalmente en un personaje sin vestigios de humanidad, cruel, calculador/a, inescrupulosa. Una figura de formas extrañas que -en los casos que utiliza esta investigación- son padres y madres progenitoras/es cuyo rol tradicional y "esperable" siempre fue el de protección hacia los miembros de la familia. Estos mismos cuidadores terminan configurándose en un monstruo, torturador de niños y niñas, con todo esto: ¿cómo debe ser la descripción de ese monstruo para que pase a convertirse en un criminal para la justicia?

Primero, ¿cómo define la psicología a la figura del perverso y/o psicópata? No solamente en las reuniones con el equipo de salud, sino en las reuniones con los/as adultos/as, en varios escritos, congresos y hasta en el discurso mediático aparece la figura del perverso o psicópata como aquel abusador de niños/as, muchas veces utilizado como sinónimos, es un término que migró rápidamente a otras esferas sociales. No fueron pocas las veces que escuché de parte de víctimas nombrar bajo esta categoría a su abusador/a o a las psicólogas para tratar de dar algún tipo de explicación al abuso, a los directivos de la ONG y en testimonios mediáticos, ni hablar: hay que etiquetar al monstruo que hizo esto. Si esa etiqueta tiene sustento disciplinar, pues mejor aún.

Si bien desde los organismos de lucha y organizaciones especializadas en la temática de abuso insisten incansablemente en que los abusadores y abusadoras no son personas enfermas, desde el discurso disciplinar se percibe otra cosa. Recordemos algunos de los panfletos que los grupos de pares distribuyen en las marchas -"No son monstruos"- es decir, cualquier persona podría ser abusador/a y no llevar marcas visibles que los delaten. Insisto en esto ya que la matriz narrativa monstruosa / perversa / psicópata todo lo impregna: los informes, las entrevistas, en las charlas con los adultos, en las marchas y ni hablar de los simposios, congresos y jornadas de debate. Pareciera que no cabe otra figura aquí. La psicología como disciplina aquí juega un papel fundamental, fue desde aquí que este término inició su desplazamiento, trabajadoras sociales pero fundamentalmente sicólogas utilizan este término para hablar de los/as abusadores/as, sobre todo en jornadas y congresos afines en la temática. En todos los 
encuentros a los que asistí las presentaciones de sus distintos/as profesionales (sobre todo sicólogas) eran casos de consultorio, pericia o evaluaciones, la reflexión disciplinar pasaba por reforzar o mencionar casos de abusos y violaciones. Cómo fueron detectados, tratados y qué cambios se dieron en el niño o niña.

Esta categoría de "perverso/a" proviene de la sicología y es utilizada por periodistas, víctimas y terapeutas para denominar a su abusador/a, en ese mismo movimiento fijan al criminal y lo condensan, una vez denominado/a así no hacen falta más explicaciones o descripciones: todo está dicho bajo esa categoría. A pesar de esto, son las mismas terapeutas y especialistas las que sostienen que no hay que patologizar el acto abusivo mucho menos al abusador/a, insisten que son personas "normales" conscientes de sus actos, no son enfermos. Pero, entonces ¿cómo nos diferenciamos de esos monstruos?, ¿cómo marcamos disciplinarmente/socialmente la frontera entre ellos y nosotros?

Podemos observar que la categoría de perverso y psicópata se utiliza indistintamente en estos discursos. Sin embargo para el psicoanálisis no existe como categoría, cuadro o estructura aquello que entendemos por psicopatía, "si consideramos las características de ausencia de culpa y prevalencia de la impulsividad sin división subjetiva, propias de estos casos, la psicopatía se acerca al diagnóstico psicoanalítico de perversión” (Tendlarz y García, 2014, p. 160). El psicópata no respeta la subjetividad del otro y genera sentimientos de angustia en la otra persona. El verdadero psicópata, dicen algunas corrientes dentro de la sicología, es quien a través de "un juego sutil de amenazas y promesas o expectativas a través de las cuales logra obtener el consentimiento del otro. Clásicamente se enfatiza la habilidad del psicópata para detectar las necesidades del otro con el fin de manipularlo y tratarlo como un objeto para alcanzar la propia satisfacción" (Ídem). Pero, reiteramos, dentro del psicoanálisis en general, las psicopatías no poseen un reconocimiento explícito, menos dentro del psicoanálisis lacaniano y del psicoanálisis de la orientación lacaniana. Sin embargo, estos autores citan a Kernberg quién caracteriza a estos sujetos como incapaces de sufrir duelos auténticos, tristeza y melancolía, solo expresan rabia e impotencia por haber sido "derrotados o descubiertos". Son "pacientes" incapaces de enamorarse o de mantener una relación de amor como parte de sus relaciones sexuales, puesto que estas están desprovistas de todo tipo de ternura. No planean a futuro, carecen de capacidad de aprendizaje y son incapaces de identificarse con valores morales. 
Ahora, si bien no está identificado como cuadro dentro de la disciplina hay autores como este que describen y hacen un acercamiento de las características de este tipo de personas. Lacan, quién hace una lectura de Freud, divide en tres categorías clínicas el campo psicopatológico: las neurosis, las psicosis y las perversiones. Y es aquí donde ingresan nuestros psicópatas.

"El psicópata no se angustia, sin embargo no le ahorra esa experiencia a su partenaire. Es más, resulta muy activo para enfrentar y sumergir al otro en la experiencia de la angustia" (Ídem, p. 163). Como concepto, la perversión sufrió una serie de cambios dentro del psicoanálisis para lograr cierta autonomía como estructura clínica despojada de contenido moral e ideológico. Recordemos como hace no muchos años la homosexualidad era considerada como una aberración y perversión, asociado el término de desviaciones sexuales con respecto a la "norma ideal" que en ese momento (y persiste aún hoy) era binaria (varón/mujer-macho/hembra). Precisamente, el psicoanálisis ha interrogado y cuestionado el lugar desde donde se legitima una conducta sexual como adecuada o no de acuerdo a la norma por oposición (sexualidadprocreación) todo por fuera de esta norma era considerada como desviación. Los cambios sociales indicaron que es necesario reconstruir ciertas categorías debido a nuevas normativas y reglas que ponen sobre la mesa el dinamismo social y cuan obsoleto quedaron estas concepciones sobre la sexualidad.

A partir de los "Tres ensayos de teoría sexual" (1905) de Freud el análisis sobre lo perverso viró. "En un sentido amplio podría decirse que la perversión es un concepto clínico que acompaña toda clase de comportamientos sexuales aberrantes y anormales" (Ídem, p. 165). Si bien reconocen (Tendlarz y García) que en psicoanálisis no utilizan (o no pretenden hacerlo) como diagnóstico de perversión a aquellas sexualidades desviadas, es el sentido que se reconoce cuando el término es utilizado en un caso de abuso sexual. Es el sentido que sobrevuela y remite al uso del término.

Freud lo entendió así, como una forma de comportamiento sexual desviado de la norma (en una sociedad heteronormativa); actualmente y sin mucho esfuerzo, sexo con niños o niñas es violación (incestuosa en algunos casos) un crimen para nuestras sociedades occidentales. "La perversión pone en cuestión el concepto mismo de sexualidad en tanto remite a una satisfacción fuera de la cópula. Debemos distinguir entonces dentro del psicoanálisis el concepto actual de perversión del concepto original, que se refería exclusivamente a la desviación de la sexualidad normal en términos 
freudianos" (Ídem, 166). Con estas concepciones ya podemos notar donde se empastan los sentidos y se inicia la codificación del acto en términos patológicos, es la codificación en términos disciplinares del accionar del abusador/a. Y es que si los violadores y violadoras están entre nosotros (como comunidad) ¿qué nos separa de ellos/as?

Pero nos podemos quedar tranquilos/as, su estructura psíquica es distinta. Hay que nominar de una forma otra para separarlos del resto. Ya lo dijo Andrea, "un padre no haría esto a sus hijos, ¿y por qué el mío si?” La coordinadora tiempo después me respondió, "porque su madre era la perversa y lo arrastró al padre".

Pero, ¿cómo se construye institucionalmente al monstruo abusador de niños y niñas? ¿Qué características tiene? ¿Cómo se registran y circulan estos perfiles en este tipo de instituciones? ¿Cómo se piensan/utilizan estos delitos en clave institucional para sancionar a estos "otros”? ¿Cómo y con quiénes dialoga esta institución en(tre) estas tramas narrativas (legales/ilegales)?

Como mencionamos anteriormente, la psicóloga repregunta por lugares, definiciones, detalles, una temporalidad que casi siempre es desconectada, difusa. El dato debe tener características tales como confiabilidad, precisión $\mathrm{y}$, sobre todo, legitimidad. La profesional debe dejar constancia en el informe de que ese relato es creíble, es verídico y que la/el niña/o está en condiciones psíquicas de prestar una declaración contundente, precisa.

Debe presentarse como prueba un cuerpo lastimado, señalando las partes ultrajadas, (de)mostrando lo quebrado que quedó. Las autoridades competentes deben creer lo que está contando ese/a niño/a. Así ese relato debe ser moldeado, codificado, volverlo "compartible" con un juez, un fiscal, un abogado. Ese daño (repugnancia, asco, vergüenza, miedo y podemos seguir enumerando) debe ser institucionalizado, debe cumplir con la mayor cantidad de requisitos/pruebas lingüísticas para que pueda convertirse en un testimonio verídico: ubicación en la trama de personajes, "villanos", móvil, requisitos de temporalidad y espacialidad... y si hay marcas físicas mejor: quien no ve no cree, dicen por estos pasillos.

Con Girard (1995) y las discusiones en torno a la crisis sacrificial, va a negar la existencia de una diferencia absoluta entre la violencia sacrificial y la violencia no sacrificial. Lejos de ser absoluta, la violencia es arbitraria, los delitos deben ser definidos: fronterizar, crear un "nosotros” y un "ellos". Pero ¿qué pasa cuando el abuso 
se comete al interior de (un) "nosotros", donde el violador es uno de los "nuestros"? Porque parte de la construcción del mal tiene que ver con eso: "expulsar moralmente de la comunidad a quienes ya han sido excluidos materialmente de la sociedad" (Tonkonoff, 2007, p. 8). Ya no hay diferencias en esa clasificación de la violencia legítima e ilegítima.

Lejos de cualquier tipo de justificación, podemos jugar con estas fronteras y límites (el adentro y el afuera) de lo legal/ilegal sólo para percibir las dificultades que el debate presenta: una alumna de 15 años teniendo sexo con su profesor de matemáticas de 24 años, un corista de 16 con un cura de 25, una trabajadora sexual de 18 años... son personas empoderadas y que toman decisiones sobre sus cuerpos, me respondió en una mesa de café una colega socióloga muy querida. ¿Y la dimensión política del debate académico? ¿Hasta dónde tirar la cuerda del relativismo? Aquí vemos como la edad (biológica y psíquica) es una de las varas que mide cuan violenta es una relación o no. Recordemos el caso de la niña abusada por su familia y la Sociedad Protectora de Animales en su auxilio, se necesitó casi 100 años más para que la infancia sea visibilizada en un marco de leyes que la proteja y vele por sus derechos recientemente inventados.

Para que opere el mecanismo de conversión de una relación sexual cualquiera a un crimen (estupro por ejemplo) el hecho debe contar con una serie de requisitos narrativos sistematizados y recolectados mediante un dispositivo de comunicación como lo es la cámara gesell. El mismo debe ser legitimado por los agentes que se encargan de codificar ese delito, en un contexto bien pautado y rígido/monitoreado como lo es una evaluación psicodiagnóstica con profesionales preparados para eso, psicólogos/trabajadores sociales. Previamente codificado en clave de delito por el Estado. El relato del abuso que en Cámara se graba no puede ser narrado o codificado según parámetros que no sean entendibles/compartibles con personal de la ley. 


\section{De la construcción de la veracidad}

Indagar en discursos institucionales rígidos como éstos no es tarea sencilla. Estamos ajustadas, limitadas, lidiando (peleando a veces) con un discurso institucional hipercodificado como lo son las ONGs, donde su estructura y cultura comunicacional se muestran muy transparentes y claras pero una vez sumergidas son truncas y opacas. E1 discurso de esta ONG tiene la característica de ser reiterativo y en esa reiteración se cristalizan muchas de sus formas, entonces cuando indagamos resulta que hay una respuesta para cada pregunta, ¿cómo movernos dentro de estas simplificaciones, limitaciones, fronteras laborales para pensar estos espacios conceptuales?

Estos testimonios no circulan en cualquier lugar ni de cualquier manera. El circuito institucional que recorren está bien delimitado, cada uno con sus reglas y protocolos internos, que a la vez respetan un marco más amplio de codificación. La mayoría de los casos de menores que reciben vienen derivados de la escuela a la que asisten, pueden ser por distintos motivos (síndrome de déficit de atención, "mala" conducta recurrente, hiperactividad, etc.) cualquier indicio que pueda significar un problema mayor lo derivan a la ONG (el departamento de psicopedagogía lo hace). Ni hablar si hay comportamientos que tengan que ver directamente con un abuso (masturbación en clases, manoseo a otros compañeros/as, gestos hipersexualizados no correspondientes con su edad, etc.). El primer lugar donde ciertos comportamientos que tienen que ver con determinada experiencia son codificados en términos de peligrosidad o, por lo menos, tenidas en cuenta en términos negativos es en la casa y en la escuela: aquí la experiencia inicia su recorrido institucional.

Otro lugar del que se derivan es desde la comisaría de la mujer, los casos sospechados de abuso sexual infantil son derivados inmediatamente para su evaluación. En cualquiera de estos casos los testimonios, antes que cualquier cosa, deben pasar por el dispositivo de cámara gesell, en este caso el formato de la herramienta de recolección de la información es a través de la E.P.

En este proceso hay una sensación o casi certeza de que "algo" está muy mal en ese chico/a, algo que está "desviado" y hay que "curarlo". El contacto con la ONG es para codificar en un segundo nivel esta sensación: ¿Qué es lo que realmente le pasa a ese niño/a? Y se recurre al lenguaje médico/forense para establecerlo, es el lenguaje referido a la salud mental el que sentencia si ese chico es "normal" o no, ellas son las 
autorizadas para nominar como problemas sus conductas. Para lograr esto, darle formato, marco teórico y sentido para el resto del recorrido institucional que falta, cuenta con varias herramientas/codificadores como ser un informe que detalla los datos de la paciente, breve reseña del caso y la metodología: entrevista y pruebas complementarias. Esto de pruebas complementarias es la batería de testeos que aplican las terapeutas para dar sustento disciplinar a lo que afirman. Dibujo libre, HTP, Persona Bajo la Lluvia, test de Bender, inventario de frases revisado, etc. Cada uno tiene su función y da respaldo a lo supuesto por la profesional, lo curioso de estas prácticas es que sin estos testeos la disciplina se queda sin herramientas para "corroborar" (en los márgenes de la psicología) lo que el niño está sufriendo ante la fiscalía, por ejemplo.... En caso de niños/as pequeños no hay un relato claro de lo ocurrido, situación en que el uso de esta batería de testeos se vuelve fundamental. Es en esta etapa donde determinan si aquello que empezó como una anomalía, pasó por síndrome, se lo codificó en términos de salud sexual es un delito contemplado y penado bajo los regímenes de este país. Hay que delimitar los márgenes, reforzar las fronteras y para esto, como vimos, cuentan con una serie de instituciones y profesionales bien diversos y bien entrenados.

En el caso de los Adultos no hay una necesidad instrumental de construcción de la verdad sino, más bien, una puesta en escena de esa verdad, una "develación", como lo llaman ellos/as. El armado de la lógica narrativa es más fuerte y los puntos o quiebres en el relato son respetados. Nadie duda de nuestra palabra, la escuché decir más de una vez a una de las coordinadoras. Y es que en el despliegue del relato no hay huecos o dudas, no hay vacilaciones, el discurso fue preparado durante años y -en el caso de este grupo- fue pensado para enunciarlo en el espacio público frente a posibles víctimas.

La mayoría de los y las participantes del grupo que se presentan en el espacio público a contar su historia ya han atravesado por varias instancias del contar, desde la justicia hasta familiares, amigos, terapeutas. La práctica narrativa de la experiencia traumática está instalada. Ni hablar de algunos de sus miembros que dedican la vida a estas luchas a través de organizaciones y redes de contención a nivel nacional, el relato del abuso pasó a convertirse en motor de "cambio", "ayuda" y "revolución" son muchas de las palabras que utilizan. El relato tiene un fuerte corte épico en términos de hazaña, gran batalla contra el Mal, un mal no difuso sino bien concreto: pervertidos/as y todo el "mundo adulto" que no hizo nada en su momento y conspiró. 
Entonces, la sensación de veracidad no pasa por el contenido en sí de los relatos, sino más bien, por las formas que adquiere ese relato en determinadas situaciones comunicativas: su estructura lógica, coherente $\mathrm{y}$, por supuesto, que sea acorde a las manifestaciones del cuerpo. El llanto es permitido en algunas situaciones, cierta cordura para el narrar en otras; lo enunciado debe tener ciertas precisiones y si no conmueve a quién escucha, el cuerpo lastimado debe ser presentado en correlato con su discurso. 
VIII. El último pasaje de formas: la codificación académica

Para llegar a esta instancia ya la experiencia traumática atravesó varias etapas y transformaciones. Si hemos de (des)armar cómo quedo configurada la experiencia nos encontraremos con varios niveles/espacios: primero en la casa/escuela, pasó a la ONG bajo el dispositivo de la cámara gesell, fue elevado a las autoridades competentes y, por último, se convirtió en documentación para ser presentada ante los/as interesados/as. Para la presente tesis todo éste recorrido fue pensado y escrito bajo los estándares de la academia. Una academia que se ubica dentro de un campo disciplinar específico (la comunicación), bajo dos paraguas teóricos-metodológicos que habilitaron las preguntas correspondientes (estudios culturales y de género) en cumplimiento de distintas instituciones que cruzan la práctica académica: comité de ética, universidad, organismo financiador (CONICET). Vale mencionar que dentro de cada una de las codificaciones que sufrió la experiencia hubo mediaciones protocolares (de distintos organismos internacionales y locales), tecnológicas, normativas y disciplinares. Todos estos cruces lograron la producción de un bien simbólico compartible y "utilizable" con distintos objetivos: como prueba ante la justicia, como material sensible de ser analizado para esta tesis, como bagaje de información para iniciar un tratamiento, como producto mediático. La experiencia traumática migró a distintas esferas de diferentes maneras y aquella pregunta que quedó al inicio ¿es posible comunicar el dolor? ya atisba de ser respondida. Es posible comunicarlo en tanto y cuanto la situación comunicativa lo habilite, lo posibilite. ¿Es posible transferir el dolor? para responder esto la tesis se valió de dos perspectivas teóricas que utilizan como insumo analítico la propia experiencia y lugar del investigador para ver si era posible acaso investigar sobre el dolor ajeno. Y es posible investigarlo en tanto y cuanto sea codificado bajo los estándares de cada situación, estamos ante una ventana quizás para estudios en comunicación que buscan dialogar con otras disciplinas interesadas en "Reparación, Verdad y Justicia" como rezan varias comisiones de la verdad en Latinoamérica. Esta discusión que buscó ser metodológica y epistemológica arroja cierto rol de comunicadores y comunicadoras frente a trabajos con otras disciplinas en sintonía con la justica, ¿qué rol cumple un comunicador en el trabajo con víctimas de abuso sexual infantil? 
Esta última codificación tuvo fines utilitarios (además de los reflexivos), cómo logramos establecer puentes desde la academia con otras instituciones conmovidas por la misma problemática. Tuvimos que atravesar este trajín analítico para empezar a preguntarnos el cómo. Aquí la mirada también fue política, seguramente roza con cierto tono moral pero esa autopercepción forma parte de los materiales de análisis. Tanto los estudios culturales como los estudios de género y sexualidades buscan problematizar el mismo lugar desde donde se reflexiona, ambas (desde distintos conceptos) se preguntan por la experiencia y el lugar de enunciación como parte del sentido de las prácticas comunicativas, útiles para la confección del corpus de análisis. Ambas perspectivas dialogan y ayudan a entender cómo podemos empezar a reflexionar sobre los espacios "habilitados" para el contar la experiencia traumática y cómo contarla, espacios configurados como parte de un orden social que busca restablecerse con cada ruptura o desvío que se presenta.

Esta última codificación y mirada tiene cruces disciplinares e institucionales, una tesis para determinado Doctorado, bajo estándares narrativos y normativos específicos. En tiempo y forma para un organismo financiador como CONICET bajo sus normativas y acuerdos. El tránsito de este material fue intenso, todos los seminarios por los que debió atravesar un proyecto para que sea aprobado y la intervención de cada profesor para el mismo, el diálogo con otras instituciones como un Comité de Ética y sus respectivas normativas. ¿Qué queda fuera de todo esto? ¿Qué queda de toda esta travesía?

Si la matriz que opera en este último pasaje de forma es la formal-académica, ¿qué otras narrativas quedan por fuera de esta lógica? ¿Qué sucede con todas aquellas sensibilidades, percepciones, sentires del investigador en campo? ¿Es material sensible de ser incorporado al corpus de análisis? Y en caso que así fuera, ¿cómo se lo codifica en términos epistemológicos? No son pocos los debates que suscita este punto, por un lado, tenemos a investigadores que luchan por una ciencia más sensible, libre de las ataduras que significan los marcos metodológicos (en Argentina Haber, Figari) "un marco nometodológico que desplaza la investigación desde la objetualización hacia la situacionalidad" (Haber, 2010, p.1); que si bien esta tesis anduvo por estos carriles determinamos una metodología específica. ¿Qué es relevante en ciencias sociales?;

¿Qué prácticas son sensibles de ser convertidas en datos? ¿qué aporta la incorporación de la experiencia sensitiva del investigador a la producción del 
conocimiento científico? Los debates sobre la experiencia siguen disparando interrogantes y los usos que le damos son varios, si mi foco de atención está puesto sobre la experiencia traumática del abuso sexual pero me es inaccesible esa experiencia per se sin su previa codificación o pasaje de formas según cada situación comunicativa, entonces el acceso a esa experiencia siempre será parcial. Recorte hecho a través de las codificaciones y mediados por la situación enunciativa, ¿qué queda fuera de estas dinámicas? A esto, irremediablemente debemos hacernos una última pregunta (por ahora) al respecto y es: ¿Es posible -en definitiva- acceder a la experiencia traumática (en términos comunicacionales) sin tantas traducciones disciplinares? 


\section{(In)conclusiones}

Siempre inacabadas

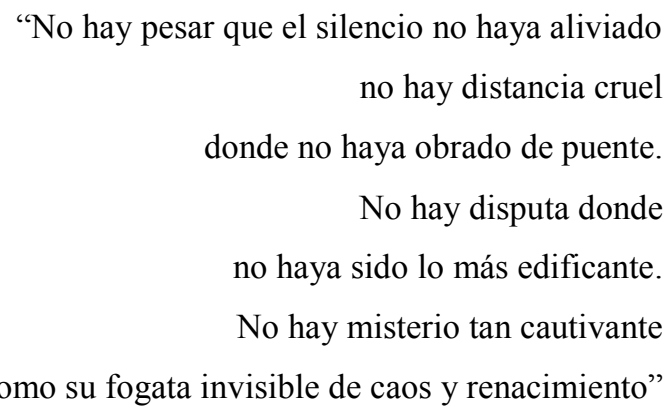

-Theodosio A. Barrios-

Vamos a dividir en dos esta última parte de la tesis. Por un lado la cuestión crítica, metodológica y epistemológica del trabajo. Una segunda parte serán las reflexiones personales que disparó (al corazón y a la mente) este trabajo.

Aquí vamos.

1. ¿La interdisciplina como perspectiva metodológica?

El desafio de comunicadoras y comunicadores en investigación

Esta propuesta metodológica estuvo presente desde el primer momento de la investigación. Sabíamos que debíamos dialogar y buscar tensiones en las disciplinas que se dedican al estudio y abordaje del trauma. Antes de iniciar mi beca doctoral AVG (Área de Vacancia Geográfica) por la provincia de Misiones tenía experiencia en investigación y extensión sobre el problema de la violencia en ámbitos varios. El trabajo en equipos de investigación donde confluyen distintas miradas y formaciones fue un plus en mi formación de grado que estaré eternamente agradecida a una Facultad que, por ser de Ciencias Sociales y Humanas, ha dialogado desde sus inicios y cimientos con las Letras, la Antropología, el Trabajo Social. No es casual el contexto en que comunicadores y comunicadoras nos hemos formado por estos lares del norte argentino, ya desde nuestros inicios y comienzos hemos dialogado: en los planes de estudios, al interior de las cátedras, en los equipos de investigación, en extensión (dónde mi Universidad tiene una trayectoria muy amplia en trazar puentes con la comunidad) en los pasillos de mates y en las mismas asambleas estudiantiles, luego docentes. 
Entonces, pensar(nos) en interdisciplina no me fue desconocido, pero sí su abordaje, pensamiento plural y cómo organizarlo. El desafío fue encontrar el recorte y la mirada entre tanta maraña, ¿qué diferencia a un/a comunicador/a de un/a antropólogo/a, de un/a sociólogo/a en el abordaje de este tipo de problemas sociales? Sin mencionar que mi directora es socióloga y mi co director es de letras, con una formación rigurosa en semiótica, debíamos buscar consensos, armados y desarmados. Las organizaciones con las que trabajamos tenían sus tradiciones disciplinares y abordajes específicos de la problemática. ¿Cómo organizar toda esta información? Debíamos encontrar aquellas categorías que nos permitiesen organizar y darle forma a este problema que se presentaba trunco e inaccesible. Así, los conceptos de Experiencia y Narrativas organizaron las notas y lecturas pero antes, los estudios que dieron sustento a ambas: los estudios poscoloniales de género y sexualidad y los estudios culturales en comunicación.

El cruce de estas perspectivas buscó el armado de una trama analítica capaz de sostener los planteos y preguntas que, en sintonía con el campo, nos provocaron y dispararon. Sostener las preguntas. Estas perspectivas resolvieron incluso la estética y la misma narrativa de la tesis: plantear un mapa analítico no fue casual, significó reconocer quienes son nuestros interlocutores, con quiénes discutimos, concordamos, respondemos. Es insertarnos en una trama de sentido reflexiva donde no estamos solas/os en la tarea de pensar al otro, el ejercicio de recorrer los principales planteos implica ejercitar la reflexividad del investigador (que no solo se despliega en campo) al momento del armado y entramado del mapa analítico y político. Para recorrer y para modificarlo.

El manejo del campo y las relaciones dentro de él no es tarea sencilla: no solo lo legal está mediando las relaciones sino -por sobre todas las cosas- el respeto a la intimidad de los sujetos. Pareciera que estamos más preocupados por entrar al campo con las "lecturas" o preguntas adecuadas y olvidamos quizás una preparación aun más compleja y que en estudios sobre sexualidades es una dimensión clave. Exponer el cuerpo al relato oral en vivo de experiencias traumáticas sin mediaciones tecnológicas, habilita las preguntas sobre la preparación corporal del investigador. 
¿Cómo es esa relación cuerpos investigados, cuerpos que investigan? (Morcillo, 2014). Y en este cara a cara, la pregunta por la ética profesional y el ejercicio responsable aparecen todo el tiempo. ¿Cuáles son los límites éticos de la escucha y la pregunta? Las preguntas por la experiencia habilitan a reflexionar por esta dimensión sensorial-experiencial del trabajo de campo que lejos de escapar a esta encrucijada que se vuelve ética por momentos, busca reflexionar no solo como insumo sino como mecanismo que interpela todo el tiempo.

En cuanto a las instituciones que velan por los derechos de los sujetos que intervienen en una investigación (Comités de Ética), el desafío (me parece) consiste en abordar la problemática de manera articulada con organismos que llevan tiempo en el tratamiento social (y reparador) de estas problemáticas. Sumado a la crítica relación disciplina científica/ sociedad civil, me pregunto: ¿Cuál es el costo de utilizar una metodología científica -"útil y aplicable” a cualquier (otro) tema/problema- en problemas que abarcan el dolor de las personas? Es decir, ¿puede ser utilizada una misma metodología para la recolección de datos que involucren experiencias traumáticas? ¿Cómo pensamos el campo teniendo en cuenta a las organizaciones que desde distintos sectores ya tienen experiencia trabajando en la temática del abuso? ¿Cuáles son los cuidados necesarios para el abordaje de las mismas en población que, organismos como CONICET considera "población vulnerable ${ }^{42, ?}$ ?

La inquietud sigue siendo por la legitimidad de estudios como estos, donde la dignidad e integridad de los sujetos está en juego, colándose en(tre) los relatos, siempre mediando la relación con el otro. Sea cual fueran "los cuidados" que podemos llegar a tener desde las ciencias, siempre ejercemos violencia al momento de encarar situaciones traumáticas. Es en la domesticación o la traducción de algo que no puede ser compartido, esa obligación de pasarlo a categorías científicas, disciplinares, allí está el meollo de la cuestión: ¿cómo investigamos sin invadir, sin violentar? ¿Existe tal cosa?

Estudios de género y sexualidad(es) habilitan a la pregunta por el otro en relación con una/o que busca (re)conocerlo y a raíz de esta pregunta es que aparece la inquietud por lo metodológico.

\footnotetext{
${ }^{42}$ CONICET (2005). Comité de ética. Reglamento. Resolución D Nro. 613 (2-5-2005), Buenos Aires: Consejo Nacional de Investigaciones Científicas y Técnicas (CONICET).
} 
2. ¿De qué sirve indagar (en) el Dolor?

¿Es legítimo investigar narrativas que tienen que ver con el dolor del otro? ¿Cómo nos interpela ese dolor? ¿Qué lugar tenemos como comunidad académica en estas nuevas cartografías de lucha? Trabajos como éstos ¿contribuyen, mejoran, intervienen favorablemente a las víctimas? ¿Cómo poner este bagaje y accionar reflexivo al servicio de las organizaciones que trabajan en la búsqueda de justicia y reparación? ¿Podría existir un uso instrumental de las conclusiones del análisis sobre la experiencia traumática en situaciones de resolución concreta?

Iván Bondar -Doctor, investigador del CONICET especialista en estudios que tienen que ver con la antropo-semiótica de la muerte y el morir- en ocasión de un panel reflexivo sobre el femicidio de Lucia Maidana ${ }^{43}$, al cual fui invitada a exponer, me respondió la pregunta que abre este último apartado:

“Sabés por qué es legítimo trabajar con el dolor ajeno? Porque como investigadores habilitamos espacios para que se descarguen y puedan hablar de aquella persona que perdieron. Durante las entrevistas que duran horas pueden contar lo que atravesaron y desahogarse."

A esta intervención, la Mgter. Elena Maidana ${ }^{44}$ responde:

"Eso desde el punto de vista de un metodólogo, nosotras en comunicación preferimos hablar de la habilitación de espacios de charla que permitan terminar de cerrar o terminar de vivir la experiencia... se traduce en escucha en nosotras pero habilita la palabra al otro."

\footnotetext{
${ }^{43}$ Lucia Maidana era estudiante de la carrera de Comunicación Social de mi Universidad. Compañera de la carrera unos años más chica que yo, fue salvajemente golpeada, violada y prendida fuego en su vivienda del barrio El Palomar de la ciudad de Posadas el 6 de abril del 2013. El crimen involucra a varios alumnos de la misma Facultad, "compañeros" que recorrían los mismos pasillos que Lucía y hoy recorren los mismos pasillos que nosotras.

Hasta el momento en que estas líneas fueron escritas no hay detenidos en la causa.

${ }^{44}$ Ex docente de la carrera de Comunicación Social, una de las principales impulsoras de la orientación en investigación en la cual me formé en grado. Investigadora de la FHyCS en temas referidos a ciudad y comunicación. Invitada también del Panel.
} 
Admito que fue una pregunta incisiva. Durante todo el panel corrimos los límites y las preguntas alrededor de "lo que podemos o no" realizar en ciencias sociales, ¿hasta dónde podemos preguntar? Quedó flotando en el ambiente y no hay ocasión en que no me haga esa pregunta cuando escucho trabajos relacionados con el dolor de las personas.

Este intercambio en términos metodológicos que se dio en este panel fue la puerta para empezar a responder (o repreguntar) sobre la legitimidad de estudios como éstos. ¿Qué objetivos debiéramos perseguir para contribuir al abordaje social de los mismos? Este estudio arrojó la posibilidad y la veta que se nos abre a comunicadores y comunicadoras interesados en estas problemáticas, una posibilidad de trabajar con otras organizaciones en el estudio y análisis de relatos sobre experiencia traumática. Además de la psicología y el trabajo social otras disciplinas de igual forma pueden indagar, ¿qué pasaría si fuéramos incluidos en equipos de interdisciplina legal y forense para la preparación de pericias y contra pericias? Siempre nos han acusado a las ciencias sociales de no poseer "aplicabilidad" de nuestros proyectos, de nuestros saberes, y aquí estamos ante un caso concreto de trabajo en campo en cruce con el trabajo legal. Los resultados de este mapeo analítico tuvieron como norte contribuir a las formas de investigar la violencia en sociedades contemporáneas.

¿Puede la comunicación, como disciplina, contribuir metodológicamente al estudio de problemas sociales? ¿Podemos, desde la comunicación, lograr una ciencia más sensible, comprometida, cercana a sus pueblos? La agenda de investigación es un aporte para la construcción de puentes con la comunidad. Pensar desde otro lugar a esa comunidad más allá de la figura de "informante" o testigo. Nacimos dialogando y todo indica que vamos hacia su consolidación como abordaje epistémico-metodológico, es hora de encontrar(nos) la veta para fortalecer estas organizaciones y contribuir a su funcionamiento no sólo en un plano legal, sino en el armado de protocolos de intervención, de funcionamiento y de estudios.

El y la lectora de estas líneas habrá notado la familiaridad de algunos recuerdos $\mathrm{y}$ de algunas pistas que arrojaron las víctimas al narrar sus propias situaciones traumáticas, hay huellas muy fuertes que nos remiten a aquellos años oscuros no solo en la Argentina sino en toda Latinoamérica. Memorias dolorosas, que dejan heridas. Los relatos de sobrevivientes y víctimas de la última dictadura cívico-eclesiástica-militar fueron huellas que aún persisten en la memoria colectiva, aún duelen y es casi inevitable 
hacer algunas comparaciones cuando escuchamos relatos como los aquí expuestos. Hay silencios sí, pero en esos silencios hay palabras, hay diálogos y articulaciones, hay vericuetos. Y en esos vericuetos nos metimos, incómoda, difícil, dudosa pero sabíamos que algunas respuestas estaban precisamente allí...en esos lugares que se mostraban como ocultos, silenciosos.

Afortunadamente, para nosotras y nosotros desde la comunicación, el silencio comunica desde siempre. Y por él fuimos. 


\section{Bibliografía}

AAVV. (2010). Informe del Grupo de Trabajo de Investigación sobre el llamado Síndrome de Alienación Parental. Ministerio de Sanidad, Política Social e Igualdad. Centro de Publicaciones. Madrid.

ACHÍO TACSAN, M. (2003). Los comités de ética y la investigación en Ciencias Sociales. Revista En Ciencias Sociales. Universidad de Costa Rica. I, 85-95.

ALABARCES, P. y AÑÓN, V. (2008). ¿Popular(es) o subalterno(s)? De la retórica a la pregunta por el poder, en Alabarces, Pablo y Ma. Graciela Rodríguez. Mediaciones y resistencias. Estudios sobre cultura popular: Buenos Aires: Paidós, pp. 281-303.

ALCOFF. L. (1999). Merleau-Ponty y la teoría feminista sobre la experiencia. Revista del Instituto Interdisciplinario de Estudios de Género. "Mora". Facultad de Filosofía y Letras. Universidad de Buenos Aires. N5/ Octubre.

ARANGUREN ROMERO, J. P.

(2010). De un dolor a un saber: cuerpo, sufrimiento y memoria en los límites de la escritura. Papeles Del CEIC, pp. 1-27. < http://papeles.identidadcolectiva.es/index.php/CEIC/article/view/67>

(2008). El investigador ante lo indecible y lo inenarrable. Revista Nómadas, N.29, pp. 20-33.

ARFUCH, L. (2013). Memoria y Autobiografía. Exploraciones en los límites. Fondo de Cultura Económica.

AUYERO, J. (2004). Etnografía y reconocimiento. Conclusión. En Vidas beligerantes. Dos mujeres argentinas, dos protestas y la búsqueda de reconocimiento. Colección Intersecciones Editorial Universidad de Quilmes.

BACCI, Claudia, ROBLES, M., OBERTI, A. y SKURA, S. (2012). Y nadie quería saber. Relatos sobre violencia contra las mujeres en el terrorismo de Estado en Argentina. Buenos Aires: Memoria Abierta.

BARRIOS, T. (2015). Al alba todos. Editorial TH. Barrios Rocha. Eldorado, Misiones. 
BAJTIN, MIJAIL/ V.VOLOSHINOV (1998). ¿Qué es el lenguaje? La construcción de la enunciación. Ensayo sobre Freud. Buenos Aires: Editorial Almagesto.

\section{BEVERLEY, J.}

(1992). Introducción. Revista de Crítica Literaria Latinoamericana - Dossier La voz del otro. Testimonio, subalternidad y verdad narrativa. URL: $<\mathrm{http}: / /$ tecnologiasdegenero.blogspot.com/

(2004) ¿Nuestra Rigoberta? Autoridad cultural y poder de gestión subalterno. En Subalternidad y representación. Debates en teoría cultural. Iberoamericana Vervuert- pp. 103-126

BIALAKOWSKY, A.; FRANCO, D.; PATROUILLEAU, M.; BARDI, N.; LUSNICH, C. (2009). Homo faber: esculpiendo hombres. La coproducción investigativa en la interioridad de una práctica. Convergencia, Vol. 16, Núm. 51, pp. 183-212. Universidad Autónoma del Estado de México. Toluca, México.

BIDASECA, K. (2012). Voces y luchas contemporáneas del feminismo negro. Corpolíticas de la violencia sexual racializada. En Afrodescendencia. Aproximaciones Contemporáneas de América Latina y El Caribe. Colección de Ensayos Del Centro de Información de Las Naciones Unidas Para México, Cuba y Rca. Dominicana. En El Marco Del Año Internacional de Los Afrodescendientes., 1-12. URL: http://www.cinu.mx/AFRODESCENDENCIA.pdf. (Acceso 11/08/2015)

BRINGIOTTI, M.

(1999). Maltrato Infantil. Factores de riesgo para el maltrato físico en la problemática infantil. Universidad de Buenos Aires. Facultad de Filosofía y Letras. Miño y Dávila editores.

(2010). Abuso sexual infanto-juvenil. Prevalencia y características en estudiantes universitarios de la ciudad de Buenos Aires. En Derecho de Familia, N46, pp. 293-305. Disponible en: <http://www.asapmi.org.ar/images/fichas/ASI\%20\%20art\%C3\%ADculo\%20Derecho\%20de\%20Flia2.pdf $>$ 


\section{BRUNER, J.}

(2003/2013). La fábrica de historias: derecho, literatura, vida. (2a ed.) Fondo de Cultura Económica. Buenos Aires.

(2004). Life as Narrative. Social Reserch, 71(3), pp.691-710.

\section{BUTLER, J.}

(1997). Sujetos de sexo/género/deseo. En Feminaria. Año X. N 19. Traducción del primer capítulo de su libro Gender Trouble.

(1999) El género en disputa. México: Paidós.

\section{CECTE}

(2001a). Documento base. Buenos Aires, Comité Nacional de Ética en la Ciencia y Tecnología.

(2001b). Misión. Buenos Aires, Comité Nacional de Ética en la Ciencia y Tecnología.

(2005). Análisis y recomendaciones para una ética en las prácticas de la investigación, Buenos Aires: Comité Nacional de Ética en la Ciencia y Tecnología. Disponible en: $<$ http://www.cecte.gov.ar/recomendaciones-e-informes/> (consulta: 03 de septiembre del 2015).

CHEJTER, S.; Kornblit, Ana Lía; Figari, Carlos; Bennett, Jane y Acha, Omar. (2009) (Conversación con coordinación del Dr. Mario Pecheny). Política, epistemología $y$ ética en la investigación social: reflexiones a partir de los estudios sobre sexualidades. 11 de septiembre, Instituto de Investigaciones Gino Germani, UBA.

CLIFFORD, J. (1995/2001). Dilemas de la cultura. Antropología, literatura y arte en la perspectiva posmoderna. Gedisa Editorial. Barcelona.

CÓDIGO DE ÉTICA de la Asociación de Psicólogos de Buenos Aires.

CÓDIGO DE ÉTICA de la Federación de Colegios de Psicólogos de la República Argentina.

CONICET (2005). Comité de ética. Reglamento. Resolución D Nro. 613 (2-52005), Buenos Aires: Consejo Nacional de Investigaciones Científicas y Técnicas (CONICET). 
DE LAURETIS, T. (1992). Semiótica y experiencia. En Alicia ya no. Feminismo, semiótica y cine. Madrid: Cátedra; pp. 251-294.

DE SOUSA SANTOS, B. (2009). Pensar el estado y la sociedad: desafíos actuales. Buenos Aires: Waldhuter Editores.

DELFINO, S. (1999). “Género y regulaciones culturales: el valor crítico de las diferencias", en Las marcas del Género. Configuraciones de la diferencia en la cultura de F. Forastelli y X. Triquell (eds.), 67-84. Córdoba: Centro de Estudios Avanzados.

\section{ELIZALDE, S.}

(2015) En Foro Clase 1A. Curso: Género y Sexualidades: Debates y herramientas para una educación intercultural. Centro Redes. http://cursos.centroredes.org.ar/mod/book/view.php?id=5984. Argentina.

(2013). Dinámicas culturales de configuración sexo- genérica. En Género y Sexualidades: Debates y herramientas para una educación intercultural. Centro Redes. http://cursos.centroredes.org.ar/mod/book/view.php?id=5984. Argentina.

(2008). Debates sobre la experiencia. Un recorrido por la teoría y la praxis feminista. Publicado en Revista Oficios Terrestres No 23, Año XIV. La Plata: Facultad de Periodismo y Comunicación Social, Universidad Nacional de La Plata, Octubre. pp.18-30. ISSN 1668-5431.

ENTEL, A. (1994). Aproximaciones a los estudios culturales: Escuela de Birmingham, en Teorías de la Comunicación. Buenos Aires. Fundación Universidad a Distancia Hernandarias.

ESCUDERO, A., AGUILAR, L., \& Cruz, J. D. La. (2008). La lógica del Síndrome de Alienación Parental de Gardner (SAP): 'terapia de la amenaza'. En Revista de La Asociación Española de Neuropsiquiatría, pp. 285-307. Disponible en $<$ http://www.asapmi.org.ar/publicaciones/articulos/articulo.asp?id=754>

ESTATUTO de la RED de Visibilización del Abuso Sexual de Niños, Niñas y Adolescentes (2015). Buenos Aires.

FIGARI, C. y HABER, A. (2001). Conocimiento situado y técnicas amorosas de la ciencia. Tópicos de epistemología crítica. Curso: Epistemologías críticas y decolonialidad. Teoría y práctica. 
FORASTELLI, F. (2008). Géneros sexuales y poscolonialidad en los estudios subalternos, en Revista deSignis N12. Pp. 101-108. Ed. La Crujía. Buenos Aires.

GARCIA, M. (2004). Narración. En Narración. Semiosis/Memoria. Posadas. Universidad Nacional de Misiones. Editorial Universitaria; p.p. 211-224.

GIRARD, R. (1995) La Crisis Sacrificial en La violencia y Lo sagrado, Anagrama. Barcelona.

GUBER, R.

(2014). (comp.) Prácticas Etnográficas. Ejercicios de reflexividad de antropólogas de campo. Buenos Aires. Miño y Dávila Editores.

(2013). La articulación etnográfica. Descubrimiento y trabajo de campo en la investigación de Esther Hermitte. Buenos Aires. Editorial Biblos

(2005). El salvaje metropolitano. Reconstrucción del conocimiento social en el trabajo de campo. Buenos Aires. Editorial Paidós. Estudios de Comunicación.

HABER, A. (2011). Nometodología payanesa. Notas de metodología indisciplinada. Escuela de Arqueología, Universidad Nacional de Catamarca y Consejo Nacional de Investigaciones Científicas y Técnicas. En Revista de Antropología, № 23, $1^{\circ}$ Semestre.

HALL, S.

(2010). El trabajo de la representación y El espectáculo del otro. En Sin garantias: Trayectorias y problemáticas en estudios culturales. Capítulos: Editado por Eduardo Restrepo, Catherine Walsh y Víctor Vich. Instituto de Estudios Sociales y Culturales Pensar, Universidad Javeriana, Instituto de Estudios Peruanos, Universidad Andina Simón Bolívar, sede Ecuador, Envión Editores.

(1984). Notas sobre la deconstrucción de lo popular, en Samuels, R. (ed.): Historia popular y teoría socialista. Barcelona: Crítica.

(1980). Codificar / Decodificar; en Cultura, Media, Lenguaje. Hutchinson \& Co. The Centre for Contemporary Cultural Studies. Londres. Traducción: Silvia Delfino; (versión electrónica). 
HARAWAY, D. (1991). Manifiesto para cyborgs: ciencia, tecnología y feminismo socialista a finales del siglo XX. En Ciencia, cyborgs y mujeres. La reinvención de la naturaleza. Madrid: Cátedra; pp. 251-311.

HARDING, S. (2002). ¿Existe un método feminista? En Eli Bartra (comp.) Debates en torno a una metodología feminista. México: PUEG/UAM Xochimilco.

\section{IIGG}

(2009). Comité de Ética. Instituto de Investigaciones Gino Germani. UBA.

FCS.

(2009). Reglamento. Instituto de Investigaciones Gino Germani. UBA. FCS.

INTEBI, I. (2011). Proteger, reparar, penalizar. Evaluación de las sospechas de abuso sexual infantil. Granica. Buenos Aires.

KRISTEVA, J. (1989) Sobre la abyección en Los Poderes de la Perversión. Siglo XXI.

MARTÍN BARBERO, J. (1998) Prefacio a la Quinta Edición, Segunda y Tercera parte; en De los medios a las mediaciones. Colombia. G.G. -Convenio Andrés Bello; pp. XI-XXII, pp. 113-333

MATTELART, A. y NEVEU, É. (2004). Introducción a los estudios culturales. Buenos Aires. Paidós.

MEO, A. (2010). Consentimiento informado, anonimato y confidencialidad en investigación social. Aposta. Revista De Ciencias Sociales, N. 44, pp. 1-30. Retrieved from <http:/www.apostadigital.com/revistav3/hemeroteca/aines.pdf $>$

MOHANTY, C. (2008). Bajo los ojos de Occidente: academia feminista y discursos coloniales y De vuelta a 'Bajo los ojos de Occidente': la solidaridad feminista a través de las luchas anticapitalistas. En L. Suárez Navaz y R. A. Hernández Castillo (eds.), Descolonizando el feminismo: Teorías y prácticas desde los márgenes. Madrid: Cátedra; pp. 117-164 y 407-464.

MORCILLO, S. (2010). ¿Ir de putas? Reflexiones en torno a las dimensiones sexuadas de la investigación. Revista Kula. Antropólogos Del Atlántico Sur, pp. 7-13.

MÜLLER, B. \& LÓPEZ, C. (2011). Los dibujos en el abuso sexual infantil. Maipue. Ituzaingó. Buenos Aires. 
OBERTI, A. (2011). Dar cuenta de sí mismas. La casa, las armas y el género. En Género, política y violencia. Vida cotidiana y militancia en las décadas del sesenta y setenta. Tesis Doctoral, Doctorado en Ciencias Sociales. FSoc/UBA: Mimeo; pp. 203241.

ORGANIZACIÓN MUNDIAL DE LA SALUD - OMS

(2001): Integrated Multisector Approach to Child Abuse: Introduction and Core Guidelines: General Information.

(2014) Sección: Maltrato Infantil. Centro de Prensa. Nota Descriptiva N 150. $<$ http://www.who.int/mediacentre/factsheets/fs150/es/>

PECHÍN, J. (2015) En Foro Debate con Juan Pechín. Curso: Género y Sexualidades: Debates y herramientas para una educación intercultural. Centro Redes. http://cursos.centroredes.org.ar/mod/book/view.php?id=5984. Argentina.

PROGRAMA LAS VÍCTIMAS CONTRA LAS VIOLENCIAS

(2007). Normativa. Ministerio de Justicia y Derechos Humanos. Presidencia de la Nación. Buenos Aires.

(2007). Objetivos Generales. Ministerio de Justicia y Derechos Humanos. Presidencia de la Nación. Buenos Aires.

RICOEUR, P. (2006). La vida: un relato en busca de narrador. Revista Ágora, N. 25(2), pp. 9-22.

RINCÓN, O. (2006). Narrativas mediáticas. O cómo se cuenta la sociedad del entretenimiento. Barcelona. Ed. Gedisa.

\section{RODRÍGUEZ, $\mathrm{M}$.}

(2011). Cultura popular: mi pie izquierdo. Revista Oficios Terrestres, № 26, La Plata: EDUNLP.

(2010). Palimpsestos: mapas, territorios y representaciones mediáticas. Revista Reflexiones Marginales.

ROZANSKI, C. (en prensa). El problema no está en las leyes sino en quién las aplica. Diario BAE. Suplementos. Martes 22 de octubre de 2013. Disponible en $<$ http://www.proteccioninfancia.org.ar/node/860> 
SARTRE, J.P. (1998) Reflexiones sobre la cuestión judía, Losada, Buenos Aires.

SAUNDERS, R. (2008). Sobre o intraduzível: sofrimento humano, a linguagem de dereitos humanos e a Comissão de Verdade e Reconciliacão da África do Sul. SUR. Revista Internacional de Dereitos Humanos, N. 9, pp. 53-76.

SCHEPER-HUGUES, N. (1997). La muerte sin llanto. Violencia y vida cotidiana en Brasil. Editorial Ariel S.A. Barcelona.

SCOTT, J. W. (2001). Experiencia. La Ventana, Revista de Estudios de género. Revista $\mathrm{N}$. 13. $<$ URL: http://148.202.18.157/sitios/publicacionesite/pperiod/laventan/Ventana13/ventana132.pdf> (Acceso: 12/08/2011)

SPIVAK, Gayatri Chakravorty (2011). ¿Puede hablar el sujeto subalterno? (trad. J. Amícola). Buenos Aires. El cuenco de plata.

TARDE, G. (2011) Qué es el Crimen en Sociología Criminal y Derecho Penal. Ad. Hoc. Estudio Preliminar Sergio Tonkonoff. Traductores: Ana Blanco, Delfina Cabrera, Sabrina García, Guido Munari, Nicolás Cardone, Sergio Tonkonoff.

TENDLARZ, S. y GARCÍA C. (2014). ¿A quién mata el asesino? Psicoanálisis y criminología. Buenos Aires. Paidós.

THEIDON, K. (2006). Género en transición: sentido común, mujeres y guerra. Cuadernos de Antropología Social, N. 24, pp. 69-92.

THOMPSON, J. (1999). Los medios y la modernidad. Una teoría de los medios de comunicación. Ed. Paidós. Pp. 13 - 60.

\section{TONKONOFF, S.}

(2007) El retorno del mal y la reconstrucción de la sociedad en Construcción de Identidades, Raúl Alcalá (comp.) Instituto de Investigaciones Filosóficas de la UNAM. México.

(2007) Tres movimientos para explicar porqué los Pibes Chorros visten ropas deportivas en Sociología Ahora, Siglo XXI Editores, Buenos Aires.

(2004) "Intercambio de tiros y tráfico de drogas etnocriminología en Río de Janeiro" en Revista Alegatos. N. 58. Universidad Autónoma Metropolitana. 
UNICEF. Convención sobre los Derechos del Niño. Disponible en $<\underline{\text { http://www.unicef.org/spanish/crc/> }}$

VASILACHIS DE GIALDINO, Irene (2006). La investigación cualitativa. En Estrategias de Investigación cualitativa. Barcelona: Gedisa Editorial.

VIAR, J. P. “Algunas consideraciones sobre el uso de la Cámara Gesell”. En Artículos. Asociación Argentina de Prevención del Maltrato Infanto Juvenil. ASAPMI. Recuperado el día 07/09/2015. Disponible en $<$ http://www.asapmi.org.ar/publicaciones/articulos/articulo.asp?id=761>

VOLNOVICH, J. (2006) (comp.) Abuso Sexual en la Infancia 2. Campo de Análisis e intervención. Lumen. Buenos Aires.

VON SPRECHER (2008). Concepto de comunicación social. Lo social, lo cultural y lo comunicacional. Propuesta de un concepto de comunicación social. Apuntes bibliográficos de Cátedra: comunicación y trabajo social. Universidad de Córdoba.

ZAFFARONI. E. (2011). La cuestión criminal. Buenos Aires. Ed. Planeta.

ZERMEÑO NIETO, O. M. (2008). Grupo de Pares de Reflexión y Ayuda Mutua (GPRAM): Modelo Emergente para la Intervención Comunitaria. En Psicología Iberoamericana, pp. 36-43.

\section{Portales}

ASAPMI.

Ministerio de Justicia y Derechos Humanos.

Organización Mundial de la Salud.

Página 12.

UNICEF.

INFOJUS. Noticias. 